\title{
Site U1430'
}

R. Tada, R.W. Murray, C.A. Alvarez Zarikian, W.T. Anderson Jr., M.-A. Bassetti, B.J. Brace, S.C. Clemens, M.H. da Costa Gurgel, G.R. Dickens, A.G. Dunlea, S.J. Gallagher, L. Giosan, A.C.G. Henderson, A.E. Holbourn, K. Ikehara, T. Irino, T. Itaki, A. Karasuda, C.W. Kinsley, Y. Kubota, G.S. Lee, K.E. Lee, J. Lofi, C.I.C.D. Lopes, L.C. Peterson, M. Saavedra-Pellitero, T. Sagawa, R.K. Singh, S. Sugisaki, S. Toucanne, S. Wan, C. Xuan, H. Zheng, and M. Ziegler²

\section{Chapter contents}

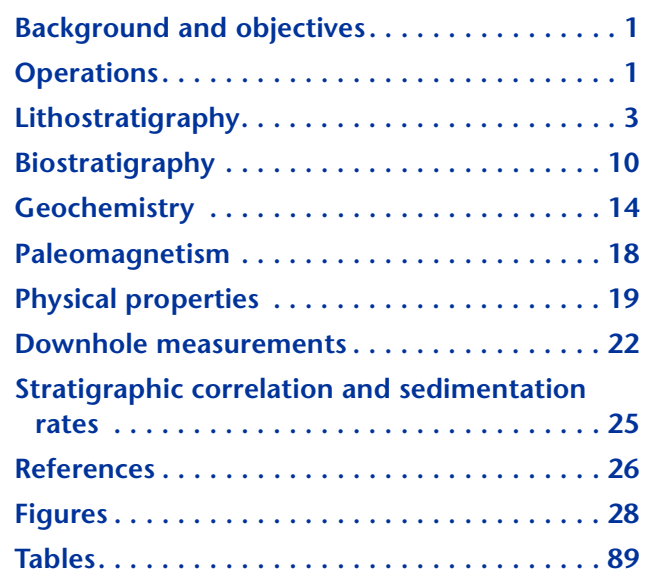

${ }^{1}$ Tada, R., Murray, R.W., Alvarez Zarikian, C.A., Anderson, W.T., Jr., Bassetti, M.-A., Brace, B.J., Clemens, S.C., da Costa Gurgel, M.H., Dickens, G.R., Dunlea, A.G., Gallagher, S.J., Giosan, L., Henderson, A.C.G., Holbourn, A.E., Ikehara, K., Irino, T., Itaki, T., Karasuda, A., Kinsley, C.W., Kubota, Y., Lee, G.S., Lee, K.E., Lofi, J., Lopes, C.I.C.D., Peterson, L.C., Saavedra-Pellitero, M., Sagawa, T., Singh, R.K., Sugisaki, S., Toucanne, S., Wan, S., Xuan, C., Zheng, H., and Ziegler, M., 2015. Site U1430. In Tada, R., Murray, R.W., Alvarez Zarikian, C.A., and the Expedition 346 Scientists, Proc. IODP, 346: College Station, TX (Integrated Ocean Drilling Program). doi:10.2204/iodp.proc.346.110.2015

2Expedition 346 Scientists' addresses.

\section{Background and objectives}

Integrated Ocean Drilling Program (IODP) Site U1430 is $~ 300 \mathrm{~km}$ southwest of IODP Site U1425 in the southwestern part of the marginal sea at $37^{\circ} 54.16^{\prime} \mathrm{N}, 131^{\circ} 32.25^{\prime} \mathrm{E}$ and 1072 meters below sea level (mbsl) (Fig. F1). The site is on the southern upper slope of the eastern South Korean Plateau, which bounds the northern margin of the Ulleung Basin. Studies of a piston core from a nearby location suggest sedimentation rates of $\sim 40 \mathrm{~m} / \mathrm{m}$.y. (Lee et al., 2008), which are as slow as those observed at Site U1425. Seismic studies suggest a sediment thickness of $285 \mathrm{~m}$ and a basal age of $\sim 10 \mathrm{Ma}$. If this is correct, the cores recovered at Site U1430 will provide a continuous slow-sedimentation record that is ideal to study the long-term history of dust provenance and flux changes since $10 \mathrm{Ma}$.

Because of its strategic location and proximity to the Asian continent, the sedimentary record at Site U1430 may contain a relatively pristine record of continental input. In addition, by combining the results from this site with those from IODP Sites U1423, U1425, and U1426 it will be possible to reconstruct changes in the position of the atmospheric Westerly Jet axis, dryness of the Gobi Desert, and the position and intensity of the early spring storm track in midlatitude Asia during the last $\sim 5$ m.y.

Site U1430 is under the influence of the second branch of the Tsushima Warm Current (TWC) but is only slightly south of the third branch, which forms the Subpolar Front (Hase et al., 1999). Therefore, the site may provide a good opportunity to monitor the behavior of the Subpolar Front and changes in intensity of the TWC (Isoda, 2011). The site is also useful to reconstruct changes in deepwater oxygenation and calcium carbonate compensation depth during the last $4 \mathrm{~m}$.y. by combining results from deeper sites such as Sites U1424 and U1425 and shallower sites such as Sites U1426 and U1427.

\section{Operations}

Three holes were cored at Site U1430 using the full and half advanced piston corer (APC) and the extended core barrel (XCB). Oriented, nonmagnetic core barrels were used with the full APC system in Hole U1430A. Half APC cores in Hole U1430A were not oriented but used nonmagnetic barrels. A total of 29 APC cores 
and $3 \mathrm{XCB}$ cores penetrated to $274.4 \mathrm{~m}$ core depth below seafloor (CSF-A) (see the "Methods" chapter [Tada et al., 2015b]) in Hole U1430A, recovering $258.24 \mathrm{~m}(94 \%)$. In Hole U1430B, 29 APC cores and $8 \mathrm{XCB}$ cores extended from the seafloor to $275 \mathrm{~m}$ CSF-A, recovering $259.71 \mathrm{~m}$ (94\%). In Hole U1430C, 33 APC cores and 1 XCB core penetrated to $250 \mathrm{~m}$ CSF-A, recovering $257.02 \mathrm{~m}(103 \%)$. Total core recovery for Site U1430 was 775 m (Table T1; see also Fig. F2 in the "Expedition 346 summary" chapter [Tada et al., 2015a]).

\section{Transit to Site U1430}

The transit from Site U1428 to Site U1430 was slowed somewhat by the effects of tropical storm Man-yi, which passed $\sim 300 \mathrm{nmi}$ to the east of the R/V JOIDES Resolution off the eastern side of Japan. Strong winds (sustained at $36 \mathrm{kt}$ and gusting to 48 kt) caused some heavy seas and reduced our transit speed to $9.0 \mathrm{kt}$. The $430.5 \mathrm{nmi}$ total distance was ultimately covered in $44.0 \mathrm{~h}$ at an average speed of 9.8 $\mathrm{kt}$. The sea passage ended at $0018 \mathrm{~h}$ on 18 September 2013. The vessel was maneuvered over the location coordinates, thrusters were lowered into position, and the vessel was turned over to dynamic positioning control. By $0100 \mathrm{~h}$, the ship was stabilized, and rig floor operations began.

\section{Hole U1430A}

A Falmouth Scientific positioning beacon (model BAP-547; SN1028W, $16 \mathrm{kHz}, 206 \mathrm{~dB}$ ) was deployed at $0123 \mathrm{~h}$ on 18 September 2013. A three-stand APC/ XCB bottom-hole assembly was assembled, and the drill string was run to the bottom. The top drive was picked up, and the bit was positioned at 1077.7 meters below rig floor (mbrf), $3.0 \mathrm{~m}$ shallower than the precision depth recorder depth. Hole U1430A was spudded at $0445 \mathrm{~h}$ on 18 September. The first core barrel recovered $3.58 \mathrm{~m}$ of sediment, establishing a seafloor depth of 1083.6 mbrf. Oriented APC coring continued using full-length nonmagnetic core barrels through Core 346-U1430A-25H to $230.7 \mathrm{~m}$ CSFA. Half APC coring with nonmagnetic core barrels continued through Core $29 \mathrm{H}$ to $249.5 \mathrm{~m}$ CSF-A, where refusal was reached in acoustic basement. The $\mathrm{XCB}$ was then used to advance the hole to $274.5 \mathrm{~m}$ CSF-A (Cores 30X through 32X). XCB coring was problematic because of the nature of the interbedded hard/soft layering of the formation. Based on poor recovery and slow penetration rates with the $\mathrm{XCB}$, the decision was made to stop coring in this hole. Hole U1430A was circulated and displaced with 114 bbl of $10.5 \mathrm{ppg}$ heavy mud, and the drill string was pulled clear of the seafloor at $0220 \mathrm{~h}$ on 19 September, ending the hole. Total recovery for Hole U1430A was $258.24 \mathrm{~m}$ (94\%); however, core recovery with the XCB system was only $1.12 \mathrm{~m}$ of the $24.9 \mathrm{~m}$ advanced $(4.5 \%)$. Four successful formation temperature measurements were taken using the advanced piston corer temperature tool (APCT-3) temperature shoe at 32.1, 60.6, 89.1, and 117.6 m CSF-A.

\section{Hole U1430B}

The ship was offset $15 \mathrm{~m}$ north of Hole U1430A. The bit was positioned at 1081.7 mbrf. An APC core barrel was deployed, and Hole U1430B was spudded at $0330 \mathrm{~h}$ on 19 September 2013. The $8.27 \mathrm{~m}$ of core recovered established a seafloor depth of 1082.9 mbrf. APC coring with full-length core barrels continued through Core 346-U1430B-25H to $234.6 \mathrm{~m}$ CSF-A. This was followed by the half APC system for Cores $26 \mathrm{H}$ through $28 \mathrm{H}$ to $246.0 \mathrm{~m}$ CSF-A. At that point, we switched to $\mathrm{XCB}$ and recovered Cores 29X through 36X to $274.1 \mathrm{~m}$ CSF-A. One final half APC core $(37 \mathrm{H})$ advanced the hole to a total depth of $275.0 \mathrm{~m}$ CSF-A. The hole was displaced with $114 \mathrm{bbl}$ of $10.5 \mathrm{ppg}$ mud, the top drive was set back, and the drill string was pulled up to a logging depth of 79.1 $m$ WSF (see the "Methods" chapter [Tada et al., 2015b]).

Rig-up for wireline logging began at $0215 \mathrm{~h}$ on 20 September. Because of the shallow hole depth and to maximize the logging data acquired, the paleo combo tool string was split into two shorter tool strings. All logging runs reached within a few meters of total hole depth, and all wireline logging runs were considered successful. By $1530 \mathrm{~h}$, the rig floor was rigged down from logging, and the drill string was pulled clear of the seafloor at $1550 \mathrm{~h}$ on $20 \mathrm{Sep}-$ tember, ending Hole U1430B. Total recovery for Hole U1430B was $259.71 \mathrm{~m}$ (94\%). A total of 25 full APC cores and 4 half APC cores were recovered. As in Hole U1430A, recovery with the XCB remained poor. Eight XCB cores were attempted, penetrating $28.1 \mathrm{~m}$ and recovering only $5.94 \mathrm{~m} \mathrm{(21 \% ).}$

\section{Hole U1430C}

Hole U1430C began as the drill string cleared the seafloor. The ship was offset $15 \mathrm{~m}$ south of Hole U1430A. The bit was positioned at 1079.7 mbrf. An APC core barrel was deployed, and Hole U1430C was spudded at $1645 \mathrm{~h}$ on 20 September 2013. The $4.78 \mathrm{~m}$ of core recovered established a seafloor depth of 1084.4 mbrf. Oriented APC coring continued using full-length nonmagnetic core barrels through Core 346-U1430C-26H to $227.3 \mathrm{~m}$ CSF-A. A single XCB barrel (Core 27X) was deployed to drill through a hard layer, penetrating $1.5 \mathrm{~m}$. This core recovered $0.05 \mathrm{~m}$ of dolomite fragments. Half APC coring with nonmagnetic core barrels continued, recovering 
Cores $28 \mathrm{H}$ through $34 \mathrm{H}$ to $250.0 \mathrm{~m}$ CSF-A. The hole was displaced with $100 \mathrm{bbl}$ of $10.5 \mathrm{ppg}$ weighted mud, the top drive was set back, and the drill string was pulled clear of the seafloor at $1215 \mathrm{~h}$ on $21 \mathrm{Sep}-$ tember. The bit was clear of the rotary table, the bit and bit sub were removed, and the rig floor was secured for transit by $1500 \mathrm{~h}$. Thrusters and hydrophones were pulled, and the sea voyage to the next site (a return to Site U1427) was initiated at $1518 \mathrm{~h}$ on 21 September. Total recovery for Hole U1430C was $257.02 \mathrm{~m}(103 \%)$. Of the 34 cores recovered, 26 were full APC cores, 7 were half APC cores, and 1 was an XCB core.

Although Site U1430 was the last newly occupied site during this expedition, because of the overall excellent coring and logistical successes to this point of the expedition additional operations time was available to enable returning to Site U1427 and then to Site U1425, as described in each of their site chapters.

\section{Lithostratigraphy}

Drilling at Site U1430 penetrated to a subbottom depth of $274.4 \mathrm{~m}$ CSF-A in Hole U1430A, recovering a total of $258.2 \mathrm{~m}$ of sediment for a recovery rate of $94 \%$. The shipboard lithostratigraphic program involved detailed visual assessment of sediment composition, color, sedimentary structures, and bioturbation intensity, supplemented by petrographic analysis of smear slides (98 from Hole U1430A and 22 from Hole U1430B), bulk mineralogic analysis by X-ray diffraction (XRD) (39 samples), and thin section analysis ( 1 sample). These objective criteria were used to describe the sediment succession, to define facies and facies associations, and to divide the stratigraphic section into major lithologic units (Figs. F2, F3, F4).

The sedimentary succession recovered at Site U1430 extends from the middle Miocene to the Holocene and is dominated by clayey silt, silty clay, nannofossil ooze, diatom ooze, claystone, and sandstone. $\mathrm{Nu}$ merous discrete tephra (i.e., volcanic ash) layers occur throughout the sedimentary sequence, especially within the upper $50 \mathrm{~m}$ (pumice more frequently) (Fig. F5), and volcaniclastic material represents a minor component of the entire sediment succession. The section is divided into four lithologic units (I, II, III, and IV, similar to Site U1425 and Tada [1994]), distinguished on the basis of sediment composition, referring particularly to the relative abundance of the biosiliceous and siliciclastic fractions. Units I-III are further divided into two subunits. The character of the sediment physical properties, including natural gamma radiation (NGR), magnetic susceptibility, and color reflectance parameters, also record downhole variations of the sediment components and lithologies (see "Physical properties"). The major characteristics of the sedimentary sequence at Site U1430, together with some of these additional properties, are summarized in Figures F2, F3, and F4. Between-hole correlation of lithologic units for Site U1430 is shown in Figure F6.

\section{Unit I}

Intervals: $346-\mathrm{U} 1430 \mathrm{~A}-1 \mathrm{H}-1,0 \mathrm{~cm}$, to $7 \mathrm{H}-5,0 \mathrm{~cm}$; $346-\mathrm{U} 1430 \mathrm{~B}-1 \mathrm{H}-0,0 \mathrm{~cm}$, to $7 \mathrm{H}-2,140 \mathrm{~cm} ; 346-$ U1430C-1H-0, $0 \mathrm{~cm}$, to $7 \mathrm{H}-4,15 \mathrm{~cm}$

Depths: Hole U1430A $=0-57.10$ m CSF-A; Hole U1430B = 0-58.70 m CSF-A; Hole U1430C $=0$ $56.95 \mathrm{~m}$ CSF-A

Age: Holocene to late Pliocene (3.0 Ma) (see "Biostratigraphy")

\section{Lithologies and structures}

Unit I consists of alternating interbedded clayey silt (greenish gray to dark olive-gray), silty clay (dark olive-gray to dark gray), foraminifer-rich diatom-bearing clayey silt, nannofossil ooze (light greenish gray), and tephra (white, gray, and black). Pyrite and volcaniclastic materials represent minor components throughout the sediment sequence. Numerous discrete millimeter- to centimeter-thick pumice clasts ( 1-5.0 mm diameter) and tephra layers (vitric and scoria) occur throughout Subunit IA (total of 71 tephra beds) (Fig. F5; Table T2).

The most distinguishing sedimentary feature of Unit I sediment is the alternating, decimeter-scale colorbanded bedding that characterizes much of the sequence, with dark organic-rich silty clay intervals interspersed with lighter colored organic-poor intervals. The relative frequency of these color alternations as well as the intensity of bioturbation are used as criteria to divide Unit I into Subunits IA and IB (Figs. F2, F3, F4). In comparison with Site U1425, the siliciclastic grains of Unit I at this site are much coarser (greater silt fraction) and have significantly higher quantities of quartz as observed in smear slides.

\section{Bulk mineralogy}

The results of XRD analyses are listed in Table T3. In general, the sediment at this site is composed mainly of quartz, plagioclase, and clay minerals (including smectite, illite, and kaolinite and/or chlorite), as well as biogenic opal-A and minor amounts of halite and pyrite. Calcite is sparse throughout the upper $50 \mathrm{~m}$ of Unit I (mostly in the form of nannofossils and foraminifers). Other minor minerals are observed in 
smear slides, but it was not possible to detect these through XRD analysis of bulk samples.

Figure F7 shows the downcore variations in peak intensity of the identified minerals in Hole U1430A. In general, the peak intensities of quartz, plagioclase, feldspar, and clay minerals (smectite, illite, and kaolinite and/or chlorite) in Unit I are higher than in other units except Unit IV, suggesting higher terrigenous input relative to biogenic material. The peak intensity of calcite is also higher than in other units but disappears abruptly downhole at $50 \mathrm{~m}$ CSF-A. In contrast, the peak height of opal-A is generally much lower in Unit I compared to other units.

\section{Subunit IA}

Intervals: $346-\mathrm{U} 1430 \mathrm{~A}-1 \mathrm{H}-1,0 \mathrm{~cm}$, to $6 \mathrm{H}-2,130$ $\mathrm{cm}$; 346-U1430B-1H-1, $0 \mathrm{~cm}$, to $5 \mathrm{H}-6,100 \mathrm{~cm}$; $346-\mathrm{U} 1430 \mathrm{C}-1 \mathrm{H}-1,0 \mathrm{~cm}$, to $6 \mathrm{H}-1,35 \mathrm{~cm}$

Depths: Hole U1430A $=0-44.40 \mathrm{~m}$ CSF-A; Hole $\mathrm{U} 1430 \mathrm{~B}=0-45.30 \mathrm{~m}$ CSF-A; Hole U1430C $=0$ $43.15 \mathrm{~m}$ CSF-A

Age: Holocene to Late Pleistocene (1.8 Ma) (see "Biostratigraphy")

\section{Lithologies and structures}

Subunit IA is dominated by silty clay with subordinant amounts of foraminifers and/or nannofossilrich ooze and diatom-bearing clayey silt. The subunit is characterized by decimeter-scale alternations of light and dark sediment intervals (Fig. F8). These alternations are also expressed in the $\mathrm{L}^{*}, \mathrm{a}^{*}$, and $\mathrm{b}^{*}$ records (see "Physical properties"). Light colored sediment intervals are dominantly composed of light greenish gray clayey silt or nannofossil ooze, occasionally with minor amounts of diatoms. Within these intervals, millimeter- to centimeter-scale layers of gray, dark greenish gray, and very dark olive-gray silty clay are observed that form distinct color banding within the sediment. The lighter intervals tend to be slightly bioturbated, though not enough to disrupt preservation of the thin, darker banding. Some prominent millimeter- to centimeter-scale olive-gray layers are also observed throughout these light intervals. Detailed examination of these layers shows they are composed of quartz and clay minerals with abundant amounts of pyrite and organic matter.

The contrasting dark layers, which dominate and help define Subunit IA, correspond to dark grayish brown silty clay intervals with more organic matter and pyrite. Tephra layers are intercalated in the silty clay sequence and form a minor but common component $(\sim 5 \%-20 \%)$ of Subunit IA. Some of these intervals show evidence of moderate to heavy bioturbation, but the dark layers are predominantly finely laminated with no apparent bioturbation (interval
346-U1430A-1H-2, 150-290 cm) (Fig. F8). Foraminifers (mostly planktonic) are generally restricted to millimeter-scale, foraminifer-bearing yellowish layers (e.g., interval 3H-6, 206-221 cm). These yellowish layers, however, are not present in all dark intervals. The lower and upper contacts of the dark layers with the lighter greenish gray intervals within Subunit IA are normally subtle and gradual, suggesting moderate to heavy bioturbation. This character is different from the weak bioturbation observed in dark layers at Site U1425.

A rather remarkable series of three very thin (0.5-1.0 $\mathrm{cm})$ yellowish calcareous ooze-rich laminated intervals (relatively more foraminifers, pyrite, and organic matter) are observed interbedded with three light green nannofossil ooze layers (relatively fewer foraminifers, less pyrite, and less organic matter) (intervals $345-\mathrm{U} 1430 \mathrm{~A}-3 \mathrm{H}-5,90 \mathrm{~cm}$, to $3 \mathrm{H}-6,55 \mathrm{~cm}$; Fig. F9). Similar carbonate-rich/ooze sequences that appear to be correlative are also observed in Sites U1423 (Section 346-U1423B-4H-6), U1424 (346U1424A-2H-7), U1425 (346-U1425B-3H-1), and U1426 (346-U1426C-6H-3), suggesting a basin-wide event.

Tephra layers in Subunit IA are typically thicker than $1 \mathrm{~cm}$ and are interbedded within the light greenish gray and dark brown/grayish brown silty clay intervals. The number of tephras per core with a thickness $>0.5 \mathrm{~cm}$ is highest in Subunit IA (Fig. F5; Table T2). Pyrite and volcaniclastic materials represent a minor sediment component $(\sim 5 \%-10 \%)$ throughout the succession. Discrete millimeter- to centimeterscale tephra layers (mostly pumice) are found throughout Subunit IA (a total of 71 tephra beds each with a thickness $>1.0 \mathrm{~cm}$ ), but only five pumice layers are found in Subunit IB.

In contrast with the occasionally pumiceous tephra found at other sites in the marginal sea (IODP Sites U1422-U1427), the prominent feature of tephra layers at this site is the much higher frequency $(47 \%$ probability) of thicker $(2-30 \mathrm{~cm})$ and coarser sized ( 1-5.0 mm diameter) pumice. The pumice is usually white to light gray in color, although the gray color likely comes from mixing with gray-colored fine ash. Tephra layers are mostly white and light gray in color (i.e., vitric), but there are some very dark to black ash layers (i.e., scoriaceous). A notably thick $(29 \mathrm{~cm})$ pumice layer was identified in Hole U1430A (interval 346-U1430A-5H-1, 0-29 cm), with its equivalent found in interval 346-U1430B-4H-2, 108$138 \mathrm{~cm}$. This particular layer provides an especially useful tie point between holes.

In Hole U1430C, the interval between Sections 346U1430C-4H-3, $83 \mathrm{~cm}$ (26.4 m CSF-A), and 5H-5, 40 cm (39.7 m CSF-A), showed inconsistent stratifica- 
tion that could not be correlated with the corresponding intervals in Holes U1430A and U1430B. Two slump structures found in intervals 346U1430C-4H-3, 83-109 cm, and $4 \mathrm{H}-3,122-133 \mathrm{~cm}$, did not occur in either Holes U1430A or U1430B. A chaotic mud underlain by an ash layer found in interval $4 \mathrm{H}-5,5-35 \mathrm{~cm}$, and a light colored homogeneous mud layer found between Sections 4H-6, 66 $\mathrm{cm}$, and 4H-7, $19 \mathrm{~cm}$, also occur only in Hole U1430C. At Section $5 \mathrm{H}-3,81 \mathrm{~cm}$, there is no apparent sequence corresponding to the $60 \mathrm{~cm}$ thick interval observed at 346-U1430A-5H-1, 40-100 cm. At Section $346-\mathrm{U} 1430 \mathrm{C}-5 \mathrm{H}-5,40 \mathrm{~cm}$, there is also no apparent sequence corresponding to the $170 \mathrm{~cm}$ thick interval found between Sections 346-U1430A$5 \mathrm{H}-3,140 \mathrm{~cm}$, and $5 \mathrm{H}-5,10 \mathrm{~cm}$.

\section{Composition}

The principal lithology of Subunit IA consists of terrigenous and biogenic grains and pumice or volcanic glass (see Site U1430 smear slides in "Core descriptions"). Terrigenous components in this subunit are dominated by silt and clay fractions. In Subunit IA, the light greenish gray intervals are mostly composed of siliciclastic fine-grained material (up to $80 \%$ ) dominated by quartz and clay minerals. However, sometimes the light greenish layers are dominated by nannofossil ooze with only a few siliciclastic grains. This subtle difference in color but distinct change in lithology is difficult to identify by the naked eye. Small pyrite framboids are distributed mainly in the dark layers. Volcanic glass accounts for nearly $100 \%$ of the ash layers, even though sometimes the volcanic material appears to be mixed with a siliciclastic component.

\section{Subunit IB}

Intervals: $346-\mathrm{U} 1430 \mathrm{~A}-6 \mathrm{H}-2,130 \mathrm{~cm}$, to $7 \mathrm{H}-5,0$ $\mathrm{cm} ; 346-\mathrm{U} 1430 \mathrm{~B}-5 \mathrm{H}-6,100 \mathrm{~cm}$, to $7 \mathrm{H}-2,140$ $\mathrm{cm} ; 346-\mathrm{U} 1430 \mathrm{C}-6 \mathrm{H}-1,35 \mathrm{~cm}$, to $7 \mathrm{H}-4,15 \mathrm{~cm}$

Depths: Hole U1430A = 44.40-57.10 m CSF-A; Hole U1430B $=45.30-58.70 \mathrm{~m}$ CSF-A; Hole $\mathrm{U} 1430 \mathrm{C}=43.15-56.95 \mathrm{~m}$ CSF-A

Age: Late Pleistocene (1.3 Ma) to late Pliocene (3.0 Ma) (see "Biostratigraphy")

\section{Lithologies and structures}

Subunit IB is a transitional sediment unit between Subunit IA and Subunit IIA. It is identified by a decrease in the frequency of the dark and light color alternations and by the increasing dominance of light greenish gray and light gray clayey silt (Fig. F10). In contrast with the $\sim 48 \mathrm{~m}$ stratigraphic thickness of Subunit IB at Site U1425, Subunit IB at Site U1430 is very condensed $(12.7 \mathrm{~m})$, suggesting a much slower sedimentation rate during deposition of this subunit at this site, or even a possible hiatus. Heavy bioturbation and large burrows (1-5 cm diameter) were observed frequently in Core 346-U1430A-6H.

Tephra layers are intercalated in the silty clay sequence and form a minor but common $(\sim 5 \%-10 \%)$ component of Subunit IB. As compared to Subunit IA, tephra layers in Subunit IB are less frequently observed. Some of the (light) tephra layers within the dark gray intervals (346-U1430A-6H-2, 60-80 cm) show distinct millimeter-scale gray and dark gray laminations. In addition, green sediment with abundant silt-size glauconite mixed with scattered pumice was observed in interval 346-U1430A-6H-7A, 23$59 \mathrm{~cm}$. Glauconite occurs in Cores 346-U1430A-6H and $9 \mathrm{H}$ (Fig. F11), corresponding to the interval of very low sedimentation rate between 50 and $80 \mathrm{~m}$ CSF-A (see "Biostratigraphy" and "Stratigraphic correlation and sedimentation rates").

\section{Composition}

The principal lithologic components in Subunit IB are terrigenous, volcanic, and biogenic in origin (see Site U1430 smear slides in "Core descriptions"). The major difference between the lithologies of Subunits IA and IB is the reduced occurrence of calcareous microfossils downhole and the generally higher contents of the biosiliceous fraction (mostly diatoms). Terrigenous materials compose the bulk (>80\%) of Unit I sediment, which is dominated by quartz and clay minerals. Volcanic glass usually occurs as a minor dispersed component $(\sim 5 \%-10 \%)$ throughout the sediment. The biogenic fraction is generally low $(<30 \%)$ in Subunit IB and is dominated by diatoms and sponge spicules, with a few calcareous microfossils.

\section{Unit II}

Intervals: $346-\mathrm{U} 1430 \mathrm{~A}-7 \mathrm{H}-5,0 \mathrm{~cm}$, to $11 \mathrm{H}-7,0 \mathrm{~cm}$; $346-\mathrm{U} 1430 \mathrm{~B}-7 \mathrm{H}-2,140 \mathrm{~cm}$, to $11 \mathrm{H}-4,140 \mathrm{~cm}$; $346-\mathrm{U} 1430 \mathrm{C}-7 \mathrm{H}-4,15 \mathrm{~cm}$, to $11 \mathrm{H}-6,0 \mathrm{~cm}$

Depths: Hole U1430A $=57.10-98.10 \mathrm{~m}$ CSF-A; Hole U1430B $=58.70-99.70 \mathrm{~m}$ CSF-A; Hole $\mathrm{U} 1430 \mathrm{C}=56.95-97.81 \mathrm{~m}$ CSF-A

Age: late Pliocene (3.0 Ma) to late Miocene (7.9 Ma) (see "Biostratigraphy")

\section{Lithologies and structures}

Unit II consists of grayish green silty clay, olive-gray diatom-rich silty clay, and dark olive-gray diatom ooze (Figs. F2, F3, F4). Unit II is distinguished from Unit I on the basis of sediment color and an increase in overall diatom content relative to terrigenous sediment. This lithologic change is supported by NGR 
measurements, which show lower values in Unit II than in Unit I and are likely to be related to variations in the relative contents of the diatomaceous and terrigenous fractions downhole (see "Physical properties"). Furthermore, XRD analyses show a large increase in opal-A content (see "Bulk mineralogy"; Fig. F7). Unit II sediment is heavily bioturbated and is often mottled. The degree of bioturbation changes vertically. The diatom content in bulk sediment is the primary criterion used to further divide Unit II into Subunits IIA and IIB.

\section{Bulk mineralogy}

The results of XRD analyses conducted on Hole U1430A sediment are listed in Table T3. In general, the character of the bulk mineral composition and peak intensity of Unit II sediment is intermediate between Units I and III.

Figure F7 shows the downcore variations in peak intensity of the identified minerals in Hole U1430A. In general, the peak intensities of quartz, plagioclase, feldspar, and clay minerals (smectite, illite, and kaolinite and/or chlorite) decrease through Unit II. In contrast, the peak height of opal-A increases through Unit II. These characteristics are consistent with the observed lithologic changes. Glauconite in this unit is observed in smear slides at Samples 346-U1430A$6 \mathrm{H}-\mathrm{CC}, 2 \mathrm{~cm}$, and 9H-4, $100 \mathrm{~cm}$ (Fig. F11). However, it is difficult to detect glauconite by XRD because the glauconite peak overlaps with the illite peak.

\section{Subunit IIA}

Intervals: $346-\mathrm{U} 1430 \mathrm{~A}-7 \mathrm{H}-5,0 \mathrm{~cm}$, to $9 \mathrm{H}-3,0 \mathrm{~cm}$; $346-\mathrm{U} 1430 \mathrm{~B}-7 \mathrm{H}-2,140 \mathrm{~cm}$, to $9 \mathrm{H}-1,0 \mathrm{~cm} ; 346-$ U1430C-7H-4, $15 \mathrm{~cm}$, to $9 \mathrm{H}-2,0 \mathrm{~cm}$

Depths: Hole U1430A $=57.10-73.10 \mathrm{~m}$ CSF-A; Hole U1430B $=58.70-74.80 \mathrm{~m}$ CSF-A; Hole $\mathrm{U} 1430 \mathrm{C}=56.95-72.80 \mathrm{~m}$ CSF-A

Age: early Pliocene (4.5 Ma) to late Pliocene (3.0 Ma) (see "Biostratigraphy")

\section{Lithologies and structures}

Subunit IIA consists dominantly of meter-scale alternating dark olive-gray, grayish green diatom-bearing and diatom-rich silty clay and very dark gray diatom ooze (Fig. F12). This subunit is considered transitional from Subunit IB to the underlying Subunit IIB, which is defined by the consistent appearance of diatom ooze. In general, the sediments of this unit are heavily bioturbated, leading to poor preservation of original sedimentary structures, which inhibits their recognition (e.g., color banding, laminae, etc.).

\section{Composition}

Subunit IIA is predominantly composed of a mixture of fine-grained material, mostly clay minerals, quartz, and biosiliceous components (see Site U1430 smear slides in "Core descriptions"). The abundance of these components varies throughout this transitional unit, with alternations of silty clay, diatom-bearing/rich silty clay, and diatom ooze.

\section{Subunit IIB}

Intervals: $346-\mathrm{U} 1430 \mathrm{~A}-9 \mathrm{H}-3,0 \mathrm{~cm}$, to $11 \mathrm{H}-7,0 \mathrm{~cm}$; $346-\mathrm{U} 1430 \mathrm{~B}-9 \mathrm{H}-1,0 \mathrm{~cm}$, to $11 \mathrm{H}-4,140 \mathrm{~cm}$; 346U1430C-9H-2, $0 \mathrm{~cm}$, to $11 \mathrm{H}-6,0 \mathrm{~cm}$

Depths: Hole U1430A = 73.10-98.10 m CSF-A; Hole U1430B $=74.80-99.70 \mathrm{~m}$ CSF-A; Hole $\mathrm{U} 1430 \mathrm{C}=72.80-97.81 \mathrm{~m}$ CSF-A

Age: early Pliocene (4.5 Ma) to late Miocene (7.9 Ma) (see "Biostratigraphy")

\section{Lithologies and structures}

Subunit IIB sediment is dominated by dark olivegray to very dark gray diatom ooze with a few dark gray silty clay intervals. The color changes within the unit are subtle. The abundance of diatoms and other siliceous components (sponge spicules and radiolarians) is key to the recognition of Subunit IIB (Fig. F13) and typically composes $>50 \%$ (mostly $90 \%$ or more) of the sediment based on smear slides. A significant decrease in NGR values from Subunit IIA to Subunit IIB coincides with the increasing diatom content of the sediment (see "Physical properties"). Moderate to heavy bioturbation is also displayed in some sections but is weaker in general than in Subunit IIA. Only three pumiceous tephra layers were observed in Subunit IIB (Table T2). The thickest layer, with a maximum thickness of $30 \mathrm{~cm}$ (not continuous and mixed with normal sediment), occurs in the lower part of Subunit IIB (interval 346-U1430A$9 \mathrm{H}-5,30-60 \mathrm{~cm})$. The other two tephra layers are very thin, $\sim 1 \mathrm{~cm}$.

Although very low sedimentation rates or the possible presence of a hiatus has been inferred for the upper part of Subunit IIB (see "Biostratigraphy" and "Stratigraphic correlation and sedimentation rates"), there is no clear visual evidence of an erosional surface or lithologic change in the upper Subunit IIB sediment except for a slightly coarser bed containing glauconite grains (interval 346-U1430A$9 \mathrm{H}-4 \mathrm{~A}, 68-150 \mathrm{~cm}$ ).

Well-lithified, pale gray dolomite beds and concretions frequently occur in Subunit IIB sediment of Site U1425. However, very few were observed at Site U1430, which is consistent with only trace amounts 
of dolomite being observed in the normal sediment by microscope and possibly indicating much weaker diagenesis at this site. In addition, some intervals of faint dark gray laminations $(\sim 60 \mathrm{~cm}$ thick, diatom ooze) are found in Sections 346-U1430A-11H-3 and $11 \mathrm{H}-6$, which can be compared with the very fine laminations in Sections 346-U1425B-38H-2 and $38 \mathrm{H}-3$ of the same age ( 8 Ma).

\section{Composition}

The major lithologies in Subunit IIB are dominated by biosiliceous (mostly diatom) components ( $>50 \%$ and up to 95\%) from Section 346-U1430A-9H-3 (i.e., the Subunit IIA/IIB transition) downhole (see Site U1430 smear slides in "Core descriptions"). Diatoms dominate in the biosiliceous fraction, whereas siliceous sponge spicules are common to rare $(20 \%-$ $5 \%)$ and radiolarians and silicoflagellates occur only in rare or trace amounts $(1 \%-5 \%)$. These siliceous fossil assemblages characterize both the dark olivegray and very dark gray sediment in the "diatom ooze" category. Scattered glauconite crystals are occasionally observed in the diatom ooze in the interval 346-U1430A-9H-4, 68-150 cm. Observed in smear slide, some glauconite grains $(\sim 50-120 \mu \mathrm{m})$ show ovoid and lobate crystal forms and a very fresh green color (Fig. F11). In some cases, glauconite is observed growing within empty diatom frustules, replacing the biosiliceous composition and preserving the original texture of the diatoms.

\section{Unit III}

Intervals: $346-\mathrm{U} 1430 \mathrm{~A}-11 \mathrm{H}-7,0 \mathrm{~cm}$, to $32 \mathrm{X}-\mathrm{CC}, 50$ $\mathrm{cm} ; 346-\mathrm{U} 1430 \mathrm{~B}-11 \mathrm{H}-4,140 \mathrm{~cm}$, to $37 \mathrm{H}-1,92$ cm; 346-U1430C-11H-6, $0 \mathrm{~cm}$, to $34 \mathrm{H}-1,92 \mathrm{~cm}$

Depths: Hole U1430A $=98.10-265.25$ m CSF-A; Hole U1430B $=99.70-275.02 \mathrm{~m}$ CSF-A; Hole $\mathrm{U} 1430 \mathrm{C}=97.81-250.02 \mathrm{~m}$ CSF-A

Age: late Miocene (7.9 Ma) to middle Miocene (13.1 Ma?) (see "Biostratigraphy")

\section{Lithologies and structures}

Unit III consists of silty clay, diatom-rich/bearing silty clay, and diatom ooze (Fig. F14), siliceous claystone (Fig. F15), and sandstone (Fig. F16). Unit III is distinguished from Unit II on the basis of a decrease in diatom contents and an increase in the terrigenous content of the sediment; nonetheless, the upper part of Unit III still has a significant amount (5\%-90\%) of diatoms. Unit III sediment is further divided into two subunits (IIIA and IIIB), and the upper sediment is moderately to heavily bioturbated and often mottled. Alternations between diatom ooze and diatom-rich/bearing silty clay are difficult to distinguish visually without smear slide observa- tions. The diatom content (i.e., biogenic silica component) decreases near the base of Subunit IIIA, and siliceous claystones and sandstones develop within Subunit IIIB and Unit IV, respectively.

\section{Bulk mineralogy}

The results of XRD analyses are listed in Table T3. In general, Unit III sediment is composed mainly of quartz, K-feldspar, plagioclase, clay minerals (including smectite, illite, and kaolinite and/or chlorite), biogenic opal-A, and minor amounts of halite and pyrite.

Figure F7 shows the downcore variations in peak intensity of the identified minerals in Hole U1430A. In Subunit IIIA, the peaks of quartz, K-feldspar, plagioclase, and clay minerals (including smectite, illite, and kaolinite and/or chlorite) have lower intensities and variation than in Unit I. In contrast, biogenic opal-A has higher intensities and greater variability than in Unit I. This character is the same as Subunit IIIA sediment at Site U1425. As a minor lithology, a concretion layer (Sample 346-U1430A-21H-6W, $43.0-44.0 \mathrm{~cm}$ ) and two rock samples (346-U1430A$22 \mathrm{H}-2 \mathrm{~W}, 87.0-88.0 \mathrm{~cm}$, and 346-U1430C-26H-CC, $11.0-12.0 \mathrm{~cm}$ ) were analyzed by XRD. A hydroxylapatite peak was detected in the concretion layer and in one of the rocks analyzed (Sample 346-U1430A$22 \mathrm{H}-2 \mathrm{~W}, 87.0-88.0 \mathrm{~cm}$ ). In the other rock (Sample 346-U1430C-26H-CC, 11.0-12.0 cm), a strong dolomite peak was detected.

In Subunit IIIB, only one sample (Sample 346U1430A-30X-CC, $22.0-23.0 \mathrm{~cm}$ ) was analyzed by $\mathrm{XRD}$, so it is difficult to characterize the subunit lithology by this means. An important change is the appearance of opal-CT at $249.72 \mathrm{~m}$ CSF-A, which appears as a large peak in intensity centered at $22^{\circ}$ $(\Delta 2 \theta)$ in the XRD diagram (Fig. F17). The appearance of opal-CT is very close to the Subunit IIIB/Unit IV boundary (249.5 m CSF-A).

\section{Subunit IIIA}

Intervals: $346-\mathrm{U} 1430 \mathrm{~A}-11 \mathrm{H}-7,0 \mathrm{~cm}$, to $28 \mathrm{H}-2,0$ $\mathrm{cm}$; 346-U1430B-11H-4, $140 \mathrm{~cm}$, to $28 \mathrm{H}-1,0$ $\mathrm{cm}$; 346-U1430C-11H-6, $0 \mathrm{~cm}$, to $30 \mathrm{H}-3,70 \mathrm{~cm}$

Depths: Hole U1430A $=98.10-241.60 \mathrm{~m}$ CSF-A; Hole U1430B $=99.70-244.00 \mathrm{~m}$ CSF-A; Hole $\mathrm{U} 1430 \mathrm{C}=97.81-241.90 \mathrm{~m}$ CSF-A

Age: Miocene (7.9-11.7 Ma) (see "Biostratigraphy")

\section{Lithologies and structures}

Subunit IIIA sediment is composed of alternating layers of heavily bioturbated diatomaceous ooze and diatom-rich/bearing silty clay (Fig. F14). These alter- 
nating layers show decimeter- to meter-scale cycles of dark gray diatom ooze (relatively clay poor) and very dark gray diatom-rich silty clay (relatively fewer diatoms and more clay), although these color changes can be subtle. Moderate to heavy bioturbation is generally restricted to the light layers in Unit III, but faint burrows (possibly Chondrites-type) are evident in the dark layers, with a large vertical burrow ( $2 \mathrm{~cm}$ diameter) observed near the top of Unit III.

An important feature of Subunit IIIA is that some (yet not all) diatom ooze sequences display very fine laminations that range from $\sim 5$ to $\sim 240 \mathrm{~cm}$ in thickness and are observed in both Holes U1430A (Fig. F18) and U1430B. These laminated intervals are not observed in the diatom-rich silty clay sequences (Fig. F14). The laminations ( 225-232 m CSF-A; 11.8 $\mathrm{Ma})$ appear within a dark organic-rich layer in Subunit IIIA that was not found at Site U1425, possibly a result of poor recovery and greater diagenesis. An unusual interval of yellowish concretion/clay-size sediment occurs at 191.4 (Sample 346-U1430A-21H6A, 41-46 cm) and 195.35 m CSF-A (Sample 22H-2A, 86-92 cm) (Fig. F19). The sediment did not react with $10 \%$ hydrochloric acid and goes nearly extinct under cross-polarized light in the microscope, suggesting no calcite is present. The composition resembles hydroxyl-apatite based on XRD results, but the exact classification and origin of these unusual yellowish layers needs further onshore study.

\section{Composition}

The principal lithology of Subunit IIIA is characterized by varying diatom content $(5 \%-75 \%$, average $=$ $40 \%$ ) associated with the common occurrence of siliceous sponge spicules (5\%-25\%) and increasing clay mineral and quartz contents (5\%-25\%) compared to Unit II. Other siliceous components such as radiolarians remain rare $(<5 \%)$, but organic matter based on smear slides becomes more common. Toward the bottom of Subunit IIIA, pyrite content also increases to become a more important component of the lithology. Overall, the biosiliceous and clay-size composition changes with the alternating color changes described above. In order to further understand the color and lithology change responsible for the fine laminations in Subunit IIIA, four samples were picked from the different color laminations (Samples 346-U1430A-24H-5, $25 \mathrm{~cm}, 24 \mathrm{H}-5,26.5 \mathrm{~cm}, 24 \mathrm{H}-5$, $33 \mathrm{~cm}$, and $24 \mathrm{H}-5,35 \mathrm{~cm}$ ) to make smear slides (Fig. F20). The normal dark gray sediment $(25 \mathrm{~cm})$ consists of about $10 \%$ diatoms (centric), $90 \%$ siliciclastic grains, and abundant organic matter. The very dark gray layer sediment $(26.5 \mathrm{~cm})$ consists of $30 \%$ pyrite and $70 \%$ diatoms (pennate), whereas the white layer sediment $(33 \mathrm{~cm})$ has $50 \%$ centric and $50 \%$ pennate diatoms. In contrast, the light gray layer sediment $(35 \mathrm{~cm})$ is rich in organic matter and pennate diatoms. The fine laminations thus reflect rapid ecologic and lithologic changes of the sediment.

\section{Subunit IIIB}

Intervals: $346-\mathrm{U} 1430-28 \mathrm{H}-2,0 \mathrm{~cm}$, to $30 \mathrm{X}-\mathrm{CC}, 0$ $\mathrm{cm}$; 346-U1430B-28H-1, $0 \mathrm{~cm}$, to 29X-CC, 45 $\mathrm{cm} ; 346-\mathrm{U} 1430 \mathrm{C}-30 \mathrm{H}-3,70 \mathrm{~cm}$, to $33 \mathrm{H}-1,0 \mathrm{~cm}$

Depths: Hole U1430A = 241.60-249.50 m CSF-A; Hole U1430B $=244.00-246.45 \mathrm{~m}$ CSF-A; Hole $\mathrm{U} 1430 \mathrm{C}=241.90-248.60 \mathrm{~m}$ CSF-A

Age: Miocene (11.7-13.1 Ma) (see "Biostratigraphy")

\section{Lithologies and structures}

Subunit IIIB sediment is characterized by dark gray siliceous silty clay and claystone with few sedimentary structures (Fig. F15). Subunit IIIB at Site U1430 covers a very short interval $(7.9 \mathrm{~m})$, in contrast to the much thicker $(63.1 \mathrm{~m})$ Subunit IIIB sequence at Site U1425. At this location it more likely represents the transition from a shallower, coarse-grained marine glauconitic facies (Unit IV) to the fine-grained and deeper hemipelagic diatomaceous sediment of Subunit IIIA. Furthermore, the estimated age of Subunit IIIB at Site U1430 appears to be somewhat older than that of Subunit IIIB at Site U1425. In addition, only two very thin (Samples 346-U1430A-28H-2, $144-152 \mathrm{~cm}$, and $29 \mathrm{H}-1,91-97 \mathrm{~cm}$ ) claystones were found interbedded with siliceous silty clay in Hole U1430A.

The transition from Subunit IIIA to Subunit IIIB is defined by the diagenetic loss of biosiliceous material (Fig. F21) and the formation of siliceous claystone. XRD results show that opal-CT first occurs between Subunit IIIB and the top of Unit IV (Fig. F17). However, it is difficult to exactly define the first downhole occurrence of opal-CT (top of Unit IV?), as only two samples in the interval were analyzed by XRD because of time limitations.

\section{Composition}

The principal lithology of Subunit IIIB is characterized by abundant clay minerals and quartz (i.e., falling within the category of $25 \%-75 \%$, see the "Methods" chapter [Tada et al., 2015b]) and the common occurrence of pyrite and organic matter (5\%-25\%). All biosiliceous material is absent from smear slides in this unit.

\section{Unit IV}

Intervals: $346-\mathrm{U} 1430-30 \mathrm{X}-\mathrm{CC}, 0 \mathrm{~cm}$, to $32 \mathrm{X}-\mathrm{CC}$, $50 \mathrm{~cm}$; 346-U1430B-29X-CC, $45 \mathrm{~cm}$, to $37 \mathrm{H}-1$, 
$92 \mathrm{~cm}$; 346-U1430C-33H-1, $0 \mathrm{~cm}$, to $34 \mathrm{H}-1,92$ $\mathrm{cm}$

Depths: Hole U1430A $=249.50-265.25$ m CSF-A; Hole U1430B $=246.45-275.02$ m CSF-A; Hole $\mathrm{U} 1430 \mathrm{C}=248.60-250.02 \mathrm{~m} \mathrm{CSF}-\mathrm{A}$

Age: middle Miocene (>13.1 Ma) (see "Biostratigraphy")

\section{Lithologies and composition}

Because of poor recovery and heavy disturbance during drilling, a detailed description of lithologic changes in Unit IV is difficult (Fig. F16). In general, Unit IV is characterized by greenish black, hard glauconite-quartz-feldspar-rich sandstone (Fig. F22), and light gray glauconite-rich dolomite-dominated sandstone (Fig. F23). A thin section of a glauconite sandstone clearly shows that glauconite occurs in the form of pellets and infilling of siliceous microfossils and coexists with pyrite, quartz, and feldspar (Fig. F24), strongly suggesting its authigenic origin in the marine environment. Moreover, the transverse section of most glauconite minerals shows an internal yellow core and a green outer crust.

The mineral compositions of Unit IV show high variability. Though based on only a few samples, XRD data (Fig. F7) are divided into three types. The first type is pure volcanic glass (Sample 346-U1430B-33X$1 \mathrm{~W}, 39.0-40.0 \mathrm{~cm}$ ). The second type shows very high peaks of quartz, plagioclase, and feldspar (Samples 346-U1430B-37H-1W, 28.0-29.0 cm, 346-U1430A30X-CCW, 22.0-23.0 cm, and 346-U1430B-32X-1W, $34.0-35.0 \mathrm{~cm}$ ). The last type shows high peaks of dolomite, quartz, plagioclase, and feldspar (Sample 346-U1430A-32X-CCW, 16.0-18.0 cm). In Unit IV, the intensities of plagioclase and feldspar peaks are much higher than in the other units. This character could be explained by grain size change or provenance change of the siliciclastic material.

Thick tephra layers were observed in Hole U1430B. A $39 \mathrm{~cm}$ thick tephra layer (vitric) appears at the bottom of Hole U1430B (interval 33X-1A, 5-44 cm). Smear slide observations show that the volcanic glass has undergone significant alteration, especially the glass proximal to the adjoining sediment (Fig. F25). The alteration products resemble clay minerals but their mineralogy needs further confirmation.

\section{Summary and discussion}

The sedimentary sequence recovered from Site U1430 records a nearly continuous history of terrigenous input and paleoceanographic evolution of the Ulleung/Tsushima Basin since the middle Miocene, as well as the gradual diagenetic development of claystones and sandstones with burial at deeper depth. The dominant lithology at Site U1430 has varied through time and is characterized by nannofossil ooze and calcareous-rich silty clay in the late Pliocene-Holocene and by diatom ooze and diatomrich silty clay from the middle Miocene to early Pliocene. Sedimentation is dominated by pelagic and/or hemipelagic biogenic grains punctuated by periods of volcanic (tephra layers) and terrigenous input (silty clay or clayey silt layers), although both terrigenous and volcanic materials represent only minor components of the sediment succession since the Miocene.

Over the last 15 m.y., the changes in major lithology at Site U1430 (and Site U1425) seem to have been largely controlled by subsidence and local sea level change in the marginal sea, which in turn was influenced by regional tectonic evolution and global sea level change. At present, the marginal sea is restricted and semi-enclosed, only connected with other seas by shallow, narrow straits, namely to the East China Sea to the south through the Tsushima Strait (130 m water depth), to the North Pacific to the east through the Tsugaru Strait $(130 \mathrm{~m}$ water depth), and to the Okhotsk Sea to the north through the Soya and Mamiya Straits (20-50 m water depth) (Tada, 1994).

The regional tectonic setting is thought to have switched from transtensional in the Miocene to compressional in the Pliocene and to convergence in the late Quaternary (Tada, 1994), which is well demonstrated by the high-frequency occurrence of tephra layers in Unit I at all sites in the marginal sea. Correspondingly, paleogeographic reconstructions suggest that the sill depths of the channels generally became shallower, from $\sim 500-1000 \mathrm{~m}$ in the middle Miocene to $\sim 130 \mathrm{~m}$ in the Pleistocene (Tada, 1994). During the middle Miocene to the early Pliocene (15-3.5 Ma), the deeper sill depths and the higher global sea level (around $+100 \mathrm{~m}$ ) relative to the Quaternary (between 0 and $-130 \mathrm{~m}$ ) suggests more open paleoceanographic conditions in the pre-Quaternary. The relatively unlimited inflow of the upper part of Pacific Deep Water would provide more nutrients such as silica that maintain the high productivity of diatoms, which are dominant from Units III to II. In contrast, the late Quaternary was significantly more restricted because of the very shallow inlet sills. During the glacial lowstands, the marginal sea was almost disconnected from the East China Sea and Pacific Ocean. The high-frequency climate and sea level changes of the Late Pleistocene induced the 
variable contributions of biogenic grains and terrigenous materials, corresponding to the alternating bands of light and dark layers observed in Unit I.

In general, terrigenous materials are not the dominant component of sediment recovered in the marginal sea. There are no large/great rivers in the Japan islands or draining the Korean mainland. Considering that $>70 \%$ of the freshwater discharged from the Yangtze River is carried into the marginal sea with the TWC (Isobe et al., 2002), some very fine clay minerals from the East China Sea are likely transported to the southern portion of the marginal sea. In any case, a more important terrigenous source may be dust transported by wind from the Asian inland. Previous studies have observed significant contributions of eolian dust to the bulk Quaternary hemipelagic sediment of the sea (Irino and Tada, 2000). Preliminary XRD results from analysis of bulk minerals at Site U1430 clearly show that quartz (mostly silt size) and clay mineral intensities have generally increased since the late Pliocene (Unit I), consistent with a strengthened East Asian winter monsoon and Asian inland aridity (Sun and An, 2005).

Another important feature of the marginal sea's sediment is the frequent occurrence of green layers and of scattered green silt- to sand-size glauconite grains within the sediment and dominant in the glauconite sandstone. Well-developed glauconite crystals usually occur in tephra layer/patches (Fig. F11) and sandstones (Fig. F24). Some glauconite seems to have grown in diatoms and to have replaced the biosiliceous composition, only to keep the original texture of the diatoms. In the green sediment that makes up much of the section, only a few (mostly $<2 \%$ ) silt-size light green glauconite grains were observed in smear slides; however, very light green aggregates (sometimes $\sim 5 \%-10 \%$ abundance) were often seen that are similar in appearance to glauconite. Nonetheless, it was not possible to confirm their mineralogy. Many theories on the origin of green layers have been proposed, and the most common one is to attribute their genesis to the diagenetic alteration of volcanic material. Gardner et al. (1986) suggested that the pale green laminae found in sediment from the Lord Howe Rise east of Australia were the product of alteration of volcanic material, as their occurrence correlated with the distribution of volcanic material and their mineralogy corresponded to bentonitic material. Based on the distribution of volcanic glass/pumice and the typical glauconite light green aggregates in the sediment of the marginal sea, it seems that the formation of glauconite may be closely linked to tephra alteration here as well, with the light green aggregates in the green layer sediment representing the initial stage of glauconitization. However, further onshore study is needed to assess the authigenic origin and process of glauconite formation.

In summary, the changes in sedimentation observed at Site U1430 since the Miocene largely reflect local and eustatic sea level changes, climate oscillations, and volcanic and diagenetic processes in the marginal sea.

\section{Biostratigraphy}

At Site U1430, 250-265 m of Miocene to Holocene sedimentary section was recovered. Nannofossils are generally absent with the exception of a few intervals where nannofossils are rare and exhibit poor preservation. One calcareous nannofossil datum, the first occurrence (FO) of Emiliania huxleyi, is documented. Diatoms are generally common and well preserved. Thirteen diatom datums are recorded. High abundances of Chaetoceros spores are indicative of a productive paleoenvironment. Laminations near $231 \mathrm{~m}$ CSF-A in Hole U1430A are found to contain different diatom assemblages in the light and dark colored layers. Radiolarians are generally abundant throughout the entire succession and are mostly well preserved. A total of 22 radiolarian datums are documented, including the last occurrence (LO) of Pentactinosphaera hokurikuensis (15.0 Ma) near $256.3 \mathrm{~m}$ CSF-A in Hole U1430B. The abundance of planktonic foraminifers is variable through the succession, ranging from rare to dominant; preservation is generally poor to moderate. The planktonic foraminiferal assemblages are characteristic of temperate to subarctic environments and primarily consist of Globigerina bulloides, Neogloboquadrina pachyderma (sinistral and dextral), and the Neogloboquadrina kagaensis group. Two datums (LO of N. kagaensis group and coiling change in $N$. pachyderma from dextral to sinistral) are identified. Benthic foraminifers are generally moderately to well preserved and abundant within the

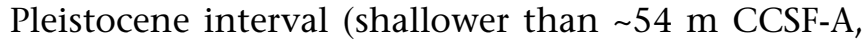
as defined in the "Methods" chapter [Tada et al., 2015b]). Alternating peak abundances in Cassidulina and Uvigerina suggest elevated but fluctuating organic export fluxes to the seafloor through the Middle to Late Pleistocene. Deeper in the succession, most samples are barren or rarely consist of an impoverished assemblage dominated by a few agglutinated species. The overall composition of benthic foraminifer assemblages at Site U1430 indicates middle bathyal paleodepths from the late Pliocene to the Pleistocene. The integrated siliceous and calcareous microfossil biozonation is shown in Figure F26 with microfossil datums listed in Table T4. A biostrati- 
graphic age-depth plot is provided in Figure F27. See "Stratigraphic correlation and sedimentation rates" for a discussion of sedimentation rates at Site U1430.

\section{Calcareous nannofossils}

Calcareous nannofossil biostratigraphy is based on analysis of 55 core catcher and split-core section samples from Holes U1430A (40 samples) and U1430B (15 samples). Nannofossils are virtually absent throughout the entire succession. A few nannofossil-bearing intervals are present between 3.5 and $137.0 \mathrm{~m}$ CSF-A (Samples 346-U1430A-1H-CC, 2H$\mathrm{CC}, 4 \mathrm{H}-\mathrm{CC}, 6 \mathrm{H}-3 \mathrm{~W}, 75 \mathrm{~cm}, 6 \mathrm{H}-\mathrm{CC}$, and $15 \mathrm{H}-\mathrm{CC})$ in Hole U1430A and between 8.2 and $27.6 \mathrm{~m}$ CSF-A (Samples 346-U1430B-1H-CC, 2H-CC, and 3H-CC) in Hole U1430B (Table T5; Fig. F28). When nannofossils are present, they are generally rare and poorly preserved.

Nannofossil diversity at Site U1430 is lower than at any other site drilled during IODP Expedition 346. The nannofossil assemblage consists of only seven taxa, including Braarudosphaera bigelowii, Calcidiscus leptoporus, Coccolithus pelagicus, E. huxleyi, Gephyrocapsa oceanica, small Gephyrocapsa spp. $(<4 \mu \mathrm{m})$, and Helicosphaera carteri.

The base of nannofossil Zones CN15/NN21 is recognized (Fig. F26) based on the FO of E. huxleyi in Hole U1430A. The underlying strata are included in nannofossil Zones CN14b/NN20 based on the absence of Pseudoemiliania lacunosa, but the base of these zones (i.e., the LO of P. lacunosa) is not identified and their zonal assignment is tentative because of the overall scarcity of nannofossils.

\section{Radiolarians}

A total of 39 samples from Holes U1430A (33 samples), U1430B (2 samples), and U1430C (4 samples) were prepared for radiolarian analyses (Table T6).

\section{Hole U1430A}

In Hole U1430A, radiolarians are generally common to abundant in the sequence, although they are rare or absent deeper than 249.7 m CSF-A (Sample 346U1430A-30X-CC) (Fig. F28). Twenty two radiolarian datums included in the Eucyrtidium inflatum Zone (middle Miocene) through the Botryostrobus aquilonaris Zone (Late Pleistocene) are found in this hole (Table T4; Fig. F26).

\section{Pleistocene}

Although key species that define the base or top of the Stylatractus universus and Eucyrtidium matuyamai Zones are not observed, secondary datums include the LO of Lychnocanoma sakaii $(0.05 \mathrm{Ma})$ at $3.5 \mathrm{~m}$ CSF-A (Sample 346-U1430A-1H-CC), Amphimelissa setosa (0.08 Ma) at $13.3 \mathrm{~m}$ CSF-A (Sample 2H-CC), Spongodiscus sp. (0.29 Ma) at $22.9 \mathrm{~m}$ CSF-A (Sample $3 \mathrm{H}-\mathrm{CC})$, and Axoprunum acquilonium (1.2-1.7 Ma) at 51.4 m CSF-A (Sample 6H-CC).

\section{Pliocene}

The Pleistocene/Pliocene boundary is close to the FO of Cycladophora davisiana $(2.7 \mathrm{Ma})$ and the $\mathrm{LO}$ of Hexacontium parviakitaensis $(2.7 \mathrm{Ma})$ at $51.4 \mathrm{~m} \mathrm{CSF}-\mathrm{A}$ (Sample 346-U1430A-6H-CC) and $60.0 \mathrm{~m}$ CSF-A (Sample 7H-CC), respectively. The FO of H. parviakitaensis (3.9-4.3 Ma) occurs at $70.4 \mathrm{~m}$ CSF-A (Sample $8 \mathrm{H}-\mathrm{CC})$. The LO of Lipmanella redondoensis (5.06 Ma) and the FO of Larcopyle pylomaticus (base of the L. pylomaticus Zone; 5.3 Ma), which are close to the Pliocene/Miocene boundary, are at $79.9 \mathrm{~m}$ CSF-A (Sample 9H-CC). However, in the same sample, Cycladophora nakasekoi (LO at 7.4 Ma) is also present, suggesting reworking from Miocene strata or the presence of a hiatus. In the absence of the A. acquilonium to Lychnocanoma parallelipes Zones (5.3-7.4 $\mathrm{Ma})$, a hiatus and/or very slow sedimentation interval are interpreted between 79.9 and $89.5 \mathrm{~m}$ CSF-A (Samples 9H-CC and 10H-CC).

\section{Miocene}

The last common occurrence of Lychnocanoma magnacoronuta (9.0 Ma) occurs at $146.5 \mathrm{~m}$ CSF-A in Hole U1430B (Sample 346-U1430B-16H-CC) corresponding to the base of the $L$. redondoensis Zone and the top of the L. magnacoronuta Zone. The FO of C. nakasekoi and the LO of Cyrtocapsella japonica (10.1 Ma) are found at $175.0 \mathrm{~m}$ CSF-A and $183.5 \mathrm{~m} \mathrm{CSF-A} \mathrm{in}$ Hole U1430B (Samples 19H-CC and 20H-CC), respectively. Dendrospyris uruyaensis ranges from 11.8 to $10.1 \mathrm{Ma}$ and is present between 202.2 and 240.4 m CSF-A (Samples 22H-CC and 27H-CC).

The FO of $L$. magnacoronuta marks the base of the $L$. magnacoronuta Zone (11.8 Ma) at $230.7 \mathrm{~m}$ CSF-A in Hole U1430A (Sample 346-U1430A-25H-CC). The LO of Eucyrtidium inflata and Lithopera renzae (11.8 Ma) are in Sample 28H-CC (245.1 m CSF-A). The rapid decrease $(\mathrm{RD})$ of $C$. tetrapera $(12.6 \mathrm{Ma})$, dividing the E. inflata Zone, is observed at $249.5 \mathrm{~m}$ CSF-A (Sample 29H-CC). The presence of Dendrospyris sakaii at $255.1 \mathrm{~m}$ CSF-A (Sample 31X-CC) suggests an age older than $14.8 \mathrm{Ma}$.

\section{Hole U1430B}

Radiolarians are abundant to common at the base of Hole U1430B (251.1-256.3 m CSF-A; Samples 346U1430B-32X-1W, 111-113 cm, and 33X-1W, 59-61 $\mathrm{cm})$. Sample 32X-1W, 111-113 cm (251.1 m CSF-A), 
lies between the LO of $D$. sakaii (14.8 Ma) and the FO of Eucyrtidium asanoi (15.3 Ma). D. sakaii (14.8 to 16$16.8 \mathrm{Ma}$ ) and P. hokurikuensis (older than $15.0 \mathrm{Ma}$ ) are present in Sample 33X-1W, 59-61 cm $(256.3 \mathrm{~m}$ CSF-A); however, E. asanoi and E. inflata (FO at 15.3 $\mathrm{Ma})$ are not present.

\section{Hole U1430C}

At the bottom of the succession in Hole U1430C, the FO of D. uruyaensis and the LO of E. inflata (11.8 Ma) are found at 238.5 and $243.0 \mathrm{~m}$ CSF-A (Samples 346U1430C-29H-CC and 30H-CC), respectively. The RD of C. tetrapera (12.6 Ma) is at $244.4 \mathrm{~m}$ CSF-A (Sample $31 \mathrm{H}-\mathrm{CC})$.

\section{Diatoms}

Diatom biostratigraphy was based on smear slides from core catcher and toothpick samples. A total of 32 core catcher and 17 toothpick samples were examined from Hole U1430A. In addition, three toothpick samples from Hole U1430B were also observed to constrain ages. Thirteen datums were identified (Table T4, T7; Fig. F29) in Hole U1430A.

The LO of Proboscia curvirostris (0.3 Ma) in Sample 346-U1430A-3H-CC (22.93 m CSF-A) marks the boundary between the base of Zone NPD 12 and the top of Zone NPD 11 (Yanagisawa and Akiba, 1998). The LO of Neodenticula koizumii (2.0 Ma) at $52.7 \mathrm{~m}$ CSF-A (Sample 7H-1W, 100-101 cm) marks the boundary between the base of Zone NPD 10 and the top of Zone NPD 9, and the LO of Neodenticula kamtschatica (2.6-2.7 Ma) in Sample 346-U1430A-7H-CC (61.0 $\mathrm{m}$ CSF-A) marks the boundary between the base of Zone NPD 9 and the top of Zone NPD 8. The FO of N. koizumii (3.4-3.9 Ma) at 62.9 m CSF-A (Sample $8 \mathrm{H}-2 \mathrm{~W}, 75 \mathrm{~cm}$ ) defines the boundary between Zones NPD 8 and NPD 7Bb. The FO of N. kamtschatica $(6.57 \mathrm{Ma})$ is in Sample 346-U1430A-9H-3W, 14 $\mathrm{cm}$, and the FO of Shionodiscus oestrupii $(5.56 \mathrm{Ma})$ is found in Sample 9H-CC (79.9 m CSF-A), marking the boundary between Zones NPD 7Bb and NPD 7Ba. The LO of Thalassionema schraderi $(7.67 \mathrm{Ma})$ at 98.9 m CSF-A (Sample 11H-CC) separates Zones NPD 7A (base) and NPD 6B (top). The FO of T. schraderi (8.5 Ma) occurs in Sample 13H-CC (118.0 m CSF-A). The boundary between Zones NPD 6B and NPD 6A is marked by the LO of Denticulopsis katayamae at 8.7 Ma (137.0 m CSF-A; Sample 15H-CC). The LO of Denticulopsis dimorpha (9.3 Ma) marks the boundary between Zones NPD 6A and NPD 5D at $156.0 \mathrm{~m}$ CSF-A (Sample 17H-CC). The LO of Denticulopsis hustedtii (10.2 Ma) is in Sample 20H-CC (183.5 m CSF-A), and the FO of this species (at $11.2 \mathrm{Ma}$ ) is in Sample $25 \mathrm{H}$ CC (230.7 m CSF-A). Finally, the FO of Denticulopsis simonsenii $(13.1 \mathrm{Ma})$ is found in Sample $27 \mathrm{H}-\mathrm{CC}$
(240.4 m CSF-A), marking the boundary between Zones NPD 5A and NPD 4Bb. In Sample 346U1430B-31X, $94 \mathrm{~cm}$, Actinocyclus ingens var. nodus is found. This species occurrence is placed within the Denticulata lauta Zone NPD 4A (Baldauf and Barron, 1980; Yanagisawa and Akiba, 1998) between 14.4 and 15.9 Ma.

Diatom preservation is good throughout the succession, except for the upper $20 \mathrm{~m}$ and the bottom $50 \mathrm{~m}$ (Fig. F28; Table T7). Overall, diatom abundances are high $(20 \%$ to $>60 \%)$ through the succession. The high abundance $(20 \%-60 \%)$ of Chaetoceros spores indicates a productive environment.

Dark and light colored laminations found in Sample 346-U1430A-25H-CC (Fig. F29) contain different diatom assemblages. Both layers are defined as diatom oozes (reflecting high productivity); however, the light colored layers have larger centrics. This may be due to an increase of nutrients from terrestrial origin and/or an increase in upwelled water flux. Further analysis, statistical and geochemical, will help to assess this hypothesis. In order to better investigate if any particular species assemblages have a significant pattern, 22 toothpick samples from light colored layers in Cores 346-U1430A-22H through $25 \mathrm{H}$ were taken in order to perform postcruise multivariate statistical analysis.

\section{Planktonic foraminifers}

Planktonic foraminifers were examined in core catcher samples from Holes U1430A (32 samples), U1430B (7 samples), and U1430C (7 samples). Relative abundances of taxa and visual estimates of assemblage preservation are presented in Table T8. Planktonic foraminifers are mainly confined to the upper part of the succession (Sample 346-U1430A$5 \mathrm{H}-\mathrm{CC}$ and shallower, Sample 346-U1430B-6H-CC and shallower, and Sample 346-U1430C-6H-CC and shallower). Their abundances vary from rare to dominant. Sample 346-U1430A-6H-CC (42.1 m CSF-A) and deeper, Sample 346-U1430B-7H-CC (42.1 m CSF-A) and deeper, and Sample 346-U1430C-7H-CC (42.1 m CSF-A) and deeper are barren (Table T8; Fig. F28). Preservation is moderate to poor because of frequent fragmentation, except for Sample 346U1430C-4H-CC (33.6 m CSF-A), which contains well-preserved tests. The frequent fragmentation may indicate partial diagenetic dissolution.

Planktonic foraminiferal assemblages are characteristic of temperate to subarctic environments, consisting mainly of G. bulloides, $N$. pachyderma (sinistral and dextral), and the N. kagaensis group (N. kagaensis and Neogloboquadrina inglei) with rare occurrences of Globigerina umbilicata, Globigerina quinqueloba, Globoturborotalita woodi, and Neogloboquadrina dutertrei 
(= Neogloboquadrina himiensis). The LO of the N. kagaensis group, which is observed at $0.7 \mathrm{Ma}$ in the North Pacific Ocean (Kucera and Kennett, 2000), is recorded between Samples 346-U1430B-4H-CC and 3H-CC (36.9 and 27.5 m CSF-A) and between Samples 346-U1430C-4H-CC and 3H-CC (33.6 and 42.2 $\mathrm{m}$ CSF-A). The change in coiling direction of $N$. pachyderma (from dextral to sinistral) occurs between Samples 346-U1430B-5H-CC (46.3 m CSF-A) and 4HCC (36.9 m CSF-A), indicating the boundary between Zones PF8 and PF7 in the regional zonation for the marginal sea (Maiya, 1978).

\section{Benthic foraminifers}

Benthic foraminifers were examined in core catcher samples from Holes U1430A (32 samples), U1430B (8 samples), and U1430C (6 samples). Samples with an average volume of $\sim 20 \mathrm{~cm}^{3}$ were processed from all core catchers to obtain quantitative estimates of benthic foraminiferal distribution patterns downhole. The mudline samples recovered in Holes U1430A and U1430B were also investigated. To assess assemblage composition and variability, all specimens from the $>150 \mu \mathrm{m}$ fraction were picked and transferred to slides for identification and counting. The presence and distribution of benthic foraminifers was additionally checked in the $63-150 \mu \mathrm{m}$ fraction to ensure that assemblages in the $>150 \mu \mathrm{m}$ fraction were representative and that small species such as phytodetritus feeders or small infaunal taxa were not overlooked. Core catcher samples were also examined for the presence of ostracods during shipboard preparation of benthic foraminifer samples, but none were found.

Benthic foraminifers vary substantially in abundance and preservation throughout the $\sim 280 \mathrm{~m}$ thick Miocene to Pleistocene succession recovered in Holes U1430A-U1430C (Figs. F28, F30; Table T9). Benthic foraminifers are generally moderately to well preserved and abundant within the Pleistocene interval shallower than Samples 346-U1430A-6H-CC, 346U1430B-6H-CC, and 346-U1430C-6H-CC (53.7, 55.6, and $57.8 \mathrm{~m} \mathrm{CCSF-A)} \mathrm{(Fig.} \mathrm{F28).} \mathrm{Deeper} \mathrm{in} \mathrm{the}$ succession, most samples are barren or consist of impoverished assemblages dominated by a few agglutinated species (Samples 346-U1430A-7H-CC though 32X-CC; 63.9-280.3 m CCSF-A). The overall composition of assemblages at Site U1430 indicates middle bathyal paleodepths from the late Pliocene to Pleistocene.

A total of 38 benthic foraminiferal taxa were identified. Table T9 summarizes the downcore distribution of benthic foraminifers in core catcher samples from
Holes U1430A-U1430C. Species commonly recorded through the succession include Bolivina pacifica, Cassidulina japonica, Cassidulina norcrossi, Epistominella pulchella, Globobulimina pacifica, Trifarina angulosa, and Uvigerina yabei, which typically indicate enhanced organic flux and/or dysoxic conditions at the seafloor and within the uppermost few centimeters of the sediment (Gooday, 1993; Jorissen et al., 1995, 2007; Jorissen, 1999). Peak abundances in Cassidulina and Uvigerina alternate in the upper part of the succession at Site U1430 (Fig. F30) suggesting elevated but fluctuating food fluxes throughout the Middle to Late Pleistocene. In contrast, the agglutinated species Martinotiella communis and Miliammina echigoensis dominate in the early Pleistocene to late Pliocene (between $\sim 68$ and $83 \mathrm{~m}$ CCSF-A). Similar distribution patterns are apparent at Sites U1422U1426 that may be related to pervasive carbonate dissolution in the marginal sea and/or to unfavorable conditions for benthic foraminifers at the seafloor during this warmer climate period. As noted previously, moderately to well-preserved diatoms and radiolarians are common to abundant in residues $>150$ and $>63 \mu \mathrm{m}$ throughout the succession, becoming dominant deeper than $227 \mathrm{~m} \mathrm{CSF-A}$ in Hole U1430A.

\section{Mudline samples}

The mudline sample from Hole U1430A was gently washed in order to preserve fragile, agglutinated foraminifer specimens with extremely low fossilization potential. The mudline sample contains planktonic foraminifers, including a few warm-water species such as Globigerinoides ruber, Globorotalia inflata, Globorotalia tumida, and Orbulina universa, reflecting the modern influence of the TWC. The mudline assemblage is dominated by agglutinated taxa including Cribrostomoides subglobosus, Haplophragmoides subsphaericum, M. echigoensis, Paratrochammina challengeri, and Reophax scorpiurus. The mudline sample also contains calcareous taxa including Amphycorina scalaris, B. pacifica, Bolivina robusta, Cassidulina japonica, Cibicidoides mundulus, Nummoloculina sp., Pyrgo spp., Pyrgoella sp., Quinqueloculina spp., Robertinoides bradyi, $T$. angulosa, and Uvigerina peregrina (Figs. F31, F32). Most of the agglutinated and calcareous tests are stained with rose bengal. The high abundance of agglutinated taxa and scarcity of highproductivity calcareous indicators (bolivinids, buliminids, and uvigerinids) suggests reduced organic export flux to the seafloor and more limited food resources than at the shallower Site U1427 located in a productive upper slope environment. 


\section{Geochemistry}

Site U1430 is located near two previously gathered piston cores (05PC-21 and KH-77-3 M3). Core 05PC21 was collected from the Ulleung Basin during a 2005 cruise of the R/V Tamhae II. Radiocarbon data and color coordination indicated fairly rapid sedimentation rates $(\sim 4 \mathrm{~cm} / \mathrm{k} . \mathrm{y}$.) for this core (Lee et al., 2008). Core KH-77-3 M3 was collected from the Tsushima Basin during a 1977 cruise of the R/V Hakuho Maru. Interstitial water data showed a rapid increase in alkalinity (to $30 \mathrm{mM}$ ) and fast decrease in $\mathrm{SO}_{4}{ }^{2-}$ (to $9 \mathrm{mM}$ ) over this $10 \mathrm{~m}$ core (Masuzawa and Kitano, 1983). The data from these other piston cores were reminiscent of some of the previous Expedition 346 drill sites. For example, over the upper $\sim 20 \mathrm{~m}$ at Site U1422, sedimentation rates are $\sim 7 \mathrm{~cm} / \mathrm{k} . \mathrm{y}$., alkalinity increases to $20 \mathrm{mM}$, and $\mathrm{SO}_{4}{ }^{2-}$ decreases to $9 \mathrm{mM}$ (see "Stratigraphic correlation and sedimentation rates" and "Geochemistry" both in the "Site U1422" chapter [Tada et al., 2015c]).

\section{Sample summary}

During operations at Site U1430, the geochemistry group collected and analyzed a range of samples. These included (Tables T10, T11, T12) the following:

- 2 mudline (ML) samples from bottom water poured from the uppermost core liner in Holes U1430A and U1430B.

- 24 interstitial water samples from whole-round squeezing (IW-Sq) from Hole U1430A; all were nominally $5 \mathrm{~cm}$ long. As at Sites U1428 and U1429, IW-Sq samples were passed through 0.45 and $0.2 \mu \mathrm{m}$ filters.

- 28 interstitial water samples from Rhizons (IW-Rh) from the top of Hole U1430B.

- 37 sediment samples from the CARB samples.

- 30 headspace (HS) gas samples.

No Vacutainer samples were taken at this site.

\section{Alkalinity, ammonium, and phosphate}

Alkalinity, $\mathrm{NH}_{4}{ }^{+}$, and $\mathrm{PO}_{4}{ }^{3-}$ exhibit similar profiles as at other numerous locations with significant amounts of organic matter degradation (Fig. F33). Alkalinity increases from $2.4 \mathrm{mM}$ in the mudline sample to $26 \mathrm{mM}$ at $24 \mathrm{~m}$ CSF-A. The value for the seafloor is close to that measured for bottom water in the region $(2.4 \mathrm{mM})$ (Sudo, 1986), and the increase is slightly steeper than at Site U1422. Below this rapid rise, alkalinity greatly increases to $40 \mathrm{mM}$ at $62 \mathrm{~m}$ CSF-A and then remains close to this level until the base of the drilled sequence.
Ammonium concentrations increase gradually from a very low value in the mudline sample $(38 \mu \mathrm{M})$ to $>1440 \mu \mathrm{M}$ at $34 \mathrm{~m}$ CSF-A (Fig. F33). The profile is slightly concave downward, at least over this depth range. At Site U1430, there is a prominent inflection in the $\mathrm{NH}_{4}{ }^{+}$profile at $\sim 30 \mathrm{~m} \mathrm{CSF-A,} \mathrm{and} \mathrm{the} \mathrm{molar} \mathrm{ra-}$ tio of alkalinity to $\mathrm{NH}_{4}{ }^{+}$is $\sim 50: 1$ at $200 \mathrm{~m} \mathrm{CSF-A.} \mathrm{Al-}$ ternatively, this inflection may be an analytical artifact of the higher $\mathrm{NH}_{4}{ }^{+}$values, as the increase from the seafloor may instead increase to an inferred maximum at $\sim 60-70 \mathrm{~m}$ CSF-A before decreasing to the bottom of the hole. However, the analyses were all well within the calibration standards, which had a maximum value of $5000 \mu \mathrm{M}$.

Phosphate concentrations increase rapidly from below the detection limit in the mudline sample to 79 $\mu \mathrm{M}$ at $\sim 15 \mathrm{~m} \mathrm{CSF-A} \mathrm{(Fig.} \mathrm{F33).} \mathrm{The} \mathrm{rise} \mathrm{is} \mathrm{greatest}$ over the uppermost $5 \mathrm{~m}$ below the seafloor. Deeper than a prominent maximum at $15 \mathrm{~m}$ CSF-A, the $\mathrm{PO}_{4}{ }^{3-}$ profile decreases gradually, with values below $20 \mu \mathrm{M}$ at $157 \mathrm{~m}$ CSF-A.

The profiles reflect a combination of several processes. As occurs at many locations, solid organic carbon, with a generic Redfield composition of $\left[\left(\mathrm{CH}_{2} \mathrm{O}\right)_{106}\left(\mathrm{NH}_{3}\right)_{16}\left(\mathrm{H}_{3} \mathrm{PO}_{4}\right)\right]$, decomposes to release $\mathrm{HCO}_{3}{ }^{-}, \mathrm{NH}_{4}{ }^{+}$, and $\mathrm{PO}_{4}{ }^{3-}$ (Froelich et al., 1979, Masuzawa and Kitano, 1983). Alkalinity often approximates $\mathrm{HCO}_{3}{ }^{-}$concentrations in the marine environment. Therefore, there are downhole increases in the three profiles. Both $\mathrm{HCO}_{3}{ }^{-}$and $\mathrm{PO}_{4}{ }^{3-}$ can precipitate into (or onto) authigenic minerals, so their concentrations can decrease with depth.

The two general reactions that may contribute significant alkalinity in clay-rich sediment are (above references)

$$
2 \mathrm{CH}_{2} \mathrm{O}+\mathrm{SO}_{4}{ }^{2-} \rightarrow \mathrm{HS}^{-}+2 \mathrm{HCO}_{3}{ }^{-}+\mathrm{H}^{+},
$$

and

$$
2 \mathrm{CH}_{2} \mathrm{O} \rightarrow \mathrm{CH}_{4}+\mathrm{HCO}_{3}^{-}+\mathrm{H}^{+} .
$$

The alkalinity of $40 \mathrm{mM}$ deeper than $80 \mathrm{~m}$ CSF-A would predict that $\mathrm{SO}_{4}{ }^{2-}$ is $<8 \mathrm{mM}$ in the interstitial water. This prediction is based upon three main points: (1) the 1:2 stoichiometry in Reaction 1, (2) the absence of $\mathrm{H}_{2} \mathrm{~S}$ odor deeper than $80 \mathrm{~m} \mathrm{CSF}-\mathrm{A}$, and (3) Reaction 2 only proceeds at minimal $\mathrm{SO}_{4}{ }^{2-}$ concentrations. Thus, for each 2 moles of $\mathrm{HCO}_{3}{ }^{-}$(alkalinity) produced, at least 1 mole of $\mathrm{SO}_{4}{ }^{2-}$ has been consumed. However, $\mathrm{SO}_{4}{ }^{2-}$ concentrations greatly exceed the $8 \mathrm{mM}$ prediction, and thus other processes must be acting. This difference between the 
prediction and measured values will be discussed below.

\section{Calcium, magnesium, and strontium}

At Site U1422 and most other sites drilled in the marginal sea (Ingle, Suyehiro, von Breymann, et al., 1990; Tamaki, Pisciotto, Allan, et al., 1990), profiles of dissolved $\mathrm{Ca}, \mathrm{Mg}$, and $\mathrm{Sr}$ are broadly similar between sites. The profiles of these elements in interstitial water at Site U1430 (Table T10; Fig. F34) continue this trend.

The dissolved Ca concentration in the mudline sample is $9.7 \mathrm{mM}$, which is slightly lower than the value expected for theoretical Japan Sea Proper Water (JSPW) (10.4 mM) (see "Geochemistry" in the "Methods" chapter [Tada et al., 2015b]). As such, either this sample is influenced by water from beneath the seafloor during sampling or the actual seawater value may be different. Nonetheless, from the seafloor values decrease to $\sim 6 \mathrm{mM}$ between 40 and $55 \mathrm{~m}$ CSF-A. Ca concentrations then increase fairly steadily with depth, reaching $13.2 \mathrm{mM}$ at $\sim 242 \mathrm{~m}$ CSF-A. This is very similar to the Ca profile at Site U1422, although the concentration at $200 \mathrm{~m}$ CSF-A is higher at Site U1430 (11.8 mM) than at Site U1422 (9.2 $\mathrm{mM})$.

The dissolved $\mathrm{Mg}$ concentration in the mudline sample is $52.0 \mathrm{mM}$, which is slightly lower than the value expected for inferred JSPW (53.3 mM) (see "Geochemistry" in the "Methods" chapter [Tada et al., 2015b]). Between 1.45 and $~ 60$ m CSF-A, Mg concentrations decrease to $\sim 48 \mathrm{mM}$ at $19 \mathrm{~m}$ CSF-A and then increase to $\sim 54 \mathrm{mM}$ at $62 \mathrm{~m} \mathrm{CSF-A.} \mathrm{At} \mathrm{Site}$ U1422, $\mathrm{Mg}$ concentrations decreased to $40 \mathrm{mM}$ in the uppermost $30 \mathrm{~m}$, most likely because of dolomite precipitation or perhaps $\mathrm{SO}_{4}{ }^{2-}$ driven by removal from interstitial water (Baker and Kastner, 1980). $\mathrm{Mg}$ concentrations between $\sim 70$ and $\sim 242 \mathrm{~m}$ CSF-A show a slight decrease to $\sim 49 \mathrm{mM}$ at the base of the cored hole.

The dissolved Sr concentration is $88 \mu \mathrm{M}$ in the mudline sample, which is lower than the $92 \mu \mathrm{M}$ that is expected for JSPW (see "Geochemistry" in the "Methods" chapter [Tada et al., 2015b]). Below the seafloor, Sr generally increases, reaching $139 \mu \mathrm{M}$ at 242 m CSF-A. An inflection in dissolved Sr seems to occur at 19.05 m CSF-A.

At previous sites drilled in the marginal sea, both during Expedition 346 and during Ocean Drilling Program Legs 127/128, two processes were invoked to explain the primary features in dissolved $\mathrm{Ca}, \mathrm{Mg}$, and Sr profiles. Authigenic carbonate formation removes $\mathrm{Ca}$ and $\mathrm{Mg}$ and releases $\mathrm{Sr}$ in shallowly buried sediment. Reactions with ash and basalt remove $\mathrm{Mg}$ and release $\mathrm{Ca}$ and $\mathrm{Sr}$ at depth.

\section{Sulfate}

Sulfate concentrations in the mudline are $28.4 \mathrm{mM}$ in Hole U1430A and $28.1 \mathrm{mM}$ in Hole U1430B (Table T10; Fig. F35). These values compare to $28.2 \mathrm{mM}$ expected for JSPW (Table T10 in the "Methods" chapter [Tada et al., 2015b]). From the seafloor, $\mathrm{SO}_{4}{ }^{2-}$ concentrations decline, expressing a smooth concave downward profile that dips to $13.4 \mathrm{mM}$ at $62 \mathrm{~m}$ CSF-A. Deeper than this depth, $\mathrm{SO}_{4}{ }^{2-}$ concentrations rise to $\sim 17.7 \mathrm{mM}$ at $242 \mathrm{~m}$ CSF-A. Earlier in the discussion, we had predicted (based on stoichiometry) that $\mathrm{SO}_{4}{ }^{2-}$ should decrease with depth to $\sim 8 \mathrm{mM}$, but values remain at $15 \mathrm{mM}$, which will be discussed later below.

\section{Volatile hydrocarbons}

Methane is the only hydrocarbon gas in the headspace samples at Site U1430. No ethane or heavier hydrocarbons were detected. Compared to $\mathrm{CH}_{4}$ concentrations at other marginal sea sites drilled during Expedition 346, values at Site U1430 are extremely low, consistently less than $\sim 10$ ppmv to the bottom of the hole (Table T11; Fig. F36). The $\mathrm{CH}_{4}$ concentration is zero in the shallowest sample at $1.5 \mathrm{~m}$ CSF-A. Deeper than $1.5 \mathrm{~m}$ CSF-A, values increase to a maximum of $\sim 9$ ppmv at $81 \mathrm{~m}$ CSF-A and then decrease to 3 ppmv at $246 \mathrm{~m}$ CSF-A. A sulfate-methane transition does not exist at Site U1430 because both species are clearly present throughout.

\section{Carbonate and organic carbon}

A simple explanation for the high interstitial water $\mathrm{SO}_{4}{ }^{2-}$ values and very low $\mathrm{CH}_{4}$ concentrations at Site U1430 concerns organic carbon content. Although seemingly conflicting with the modest alkalinity concentrations, low amounts of organic matter would maintain high $\mathrm{SO}_{4}{ }^{2-}$ concentrations, which would preclude significant methanogenesis. The solid-phase profiles at Site U1430 (Table T12; Fig. F37) make this interpretation very problematic.

Organic carbon contents across the upper $\sim 70 \mathrm{~m}$ below seafloor average $1.1 \mathrm{wt} \%$ and range from 0.5 to 3 wt $\%$. Deeper than this depth, values increase, averaging $3.3 \mathrm{wt} \%$ and fluctuating between 1.7 and 4.5 $\mathrm{wt} \%$. For the entire sediment column drilled, organic carbon contents are generally higher at Site U1430 than at other sites drilled during Expedition 346.

The C:N ratio in the upper $\sim 70 \mathrm{~m}$ of sediment is relatively low with an average value of $\sim 6$. Between this 
depth and $\sim 242 \mathrm{~m}$ CSF-A, the C:N ratio averages 11 . The organic matter in the upper sediment is of marine origin, whereas that in the lower sediment appears to be derived from marine and terrestrial sources.

The carbonate contents of sediment at Site U1430 vary significantly. They are relatively high in the upper $\sim 70 \mathrm{~m}$ CSF-A, although values fluctuate between 2 and $33 \mathrm{wt} \%$. Deeper than $\sim 70 \mathrm{~m}$ CSF-A, carbonate contents of sediment show little variation, except at the very base of the cored sequence. Values are $<1$ wt $\%$ until $230 \mathrm{~m}$ CSF-A. Near the bottom of the site (232-245 m CSF-A), carbonate contents increase to 5 wt $\%$.

\section{The problem and a solution}

Despite some similarities to other drill sites of Expedition 346, especially Site U1422, and other sites from many other legs and expeditions, Site U1430 is different. The basic geochemical puzzle at Site U1430 is the combination of (1) interstitial water with fairly high alkalinity, moderate $\mathrm{SO}_{4}{ }^{2-}$, and effectively no $\mathrm{CH}_{4}$ and (2) clay-rich sediment with high organic carbon contents. We think the answer takes into consideration the site's location and two reactions potentially occurring near the base of the sediment sequence:

$$
\begin{aligned}
& 4 \mathrm{FeS}_{2}+15 \mathrm{O}_{2}+10 \mathrm{H}_{2} \mathrm{O} \rightarrow \\
& 4 \mathrm{FeOOH}+8 \mathrm{SO}_{4}{ }^{2-}+16 \mathrm{H}^{+},
\end{aligned}
$$

and

$$
\mathrm{CaCO}_{3}+\mathrm{H}^{+} \rightarrow \mathrm{Ca}^{2+}+\mathrm{HCO}_{3}{ }^{-} .
$$

The first of these reactions represents the dissolution of pyrite, whereas the second represents the dissolution of carbonate. The net result is the generation of $\mathrm{SO}_{4}{ }^{2-}, \mathrm{H}^{+}, \mathrm{Ca}^{2+}$, and $\mathrm{HCO}_{3}{ }^{-}$. The reactions are well known from studies of different environments. Indeed, considerable effort was expended during Expedition 346 to prevent these reactions from occurring after cores are recovered (see "Lithostratigraphy"), as these reactions cause the dissolution of carbonate microfossils during core storage.

In situ Fe sulfide oxidation explains the geochemical puzzle at Site U1430. High $\mathrm{SO}_{4}{ }^{2-}$ concentrations are maintained at depth, indeed generated at depth, through Reaction 3.

Alkalinity is maintained because of carbonate dissolution, especially near the base of the cored sequence. In fact, carbonate contents at this location, including authigenic phases (see "Lithostratigraphy"), may be very low because of Reaction 4 (and derivatives thereof for other carbonate phases, such as dolomite). Generation of high alkalinity without degrading organic matter also yields the extremely high alkalinity: $\mathrm{NH}_{4}{ }^{+}$ratio, a ratio much greater than that of the Redfield ratio, the surrounding sedimentary organic carbon, or that observed at the other drill sites. We suggest the evidence for these paired reactions is compelling, both from the geochemistry and the lithology, as elaborated below.

\section{pH}

Throughout Expedition 346, we generally have omitted discussion of interstitial water $\mathrm{pH}$. This is because it invariably lies between 7.1 and 8.1 and reflects the combination of many factors, not the least of which is the difficulty of the measurement itself. For example, the $\mathrm{pH}$ at Site U1422 ranges between 7.6 and 8.1. At Site U1430, the $\mathrm{pH}$ at the bottom of the hole is $<6.3$. This $\mathrm{pH}$ is exceptionally low for interstitial water and is consistent with input of acid.

\section{Manganese and iron}

The Mn and Fe profiles (Table T10; Fig. F38) are similar to those at other locations, with the notable exception of peaks near the bottom of the cored sequence. Mn concentrations of the mudline samples are below the detection limit $(0.3 \mu \mathrm{M})$ in Hole U1430A and $6.76 \mu \mathrm{M}$ in Hole U1430B. Two local maximum concentrations of $\mathrm{Mn}$ are $55 \mu \mathrm{M}$ in the first Rhizon sample at $0.05 \mathrm{~m}$ CSF-A and $18 \mu \mathrm{M}$ at $0.8 \mathrm{~m}$ CSF-A (Table T10). A local minimum of $5 \mu \mathrm{M}$ at $0.15 \mathrm{~m}$ CSF-A separates the two maxima. Below the second maximum, concentrations decrease to $<4$ $\mu \mathrm{M}$ until $138 \mathrm{~m}$ CSF-A. However, toward the base of the sequence, several IW-Sq samples have elevated dissolved Mn concentrations of 6-9 $\mu \mathrm{M}$.

Dissolved Fe concentrations are below the detection limit $(0.9 \mu \mathrm{M})$ for the mudline samples. The maximum Fe concentration $(202 \mu \mathrm{M})$ occurs just below the seafloor in the uppermost Rhizon sample at 0.05 $\mathrm{m}$ CSF-A (Table T10). Concentrations decrease to 11 $\mu \mathrm{M}$ at $0.15 \mathrm{~m}$ CSF-A before increasing again to 19 $\mu \mathrm{M}$ at $0.3 \mathrm{~m}$ CSF-A. Fe concentrations in IW-Rh samples then decrease to below the detection limit at 0.8 $\mathrm{m}$ CSF-A, except for a few values just above the detection limit. Fe concentrations in the IW-Sq samples remain above the detection limit until $34 \mathrm{~m}$ CSF-A, showing a local maximum of $13 \mu \mathrm{M}$ at 19.05 $\mathrm{m}$ CSF-A. Although Fe concentrations of IW-Sq and IW-Rh samples do not match perfectly, "double filtering" with a $0.45 \mu \mathrm{m}$ and $0.2 \mu \mathrm{m}$ filter of the IW-Sq samples may have resulted in Fe concentrations remaining below the detection limit for most deep samples at Site U1430. This contrasts with the scat- 
tered "dissolved" Fe records at Sites U1422-U1427, where only a $0.45 \mu \mathrm{m}$ filter was used. Most crucially, and despite the double filtering, several samples near the base of the cored sequence have high dissolved Fe concentrations. This is consistent with interstitial water coming from sediment where Fe sulfides are being oxidized.

\section{Sediment color}

Upon realizing the possibility of deep oxidation of sediment, we examined cores displayed in the Sedimentology Laboratory. Unit III, generally composed of green-gray sediment, has abundant intervals rich in diatoms with relatively high amounts of pyrite (see "Lithostratigraphy"). However, there are also several diatom-rich horizons deeper than 190 m CSF-A where sediments have a burnt red color. We suggest this red location is where pyrite has been oxidized.

Once one realizes that the co-occurrence of high alkalinity and high $\mathrm{SO}_{4}{ }^{2-}$ at depth at Site U1430 may result from oxidation of Fe sulfides, the remaining constituents measured on the ship are relatively straightforward to understand because they are not affected too much by Fe sulfide oxidation.

\section{Barium}

Dissolved Ba concentration is below the detection limit $(5 \mu \mathrm{M})$ in the mudline samples, as expected for seawater (Table T10). Below the seafloor, Ba is below the detection limit in all Rhizon samples and low but detectable $(6-21 \mu \mathrm{M})$ in all squeezed samples. The discrepancy in Ba values between sample techniques, identified at previous sites, remains at Site U1430, despite additional filtering when collecting IW-Sq samples. The main point of interest is that the relatively high $\mathrm{SO}_{4}{ }^{2-}$ concentrations at depth preclude significant dissolution of barite in the sediment column.

\section{Potassium}

K concentration is $\sim 10.5 \mathrm{mM}$ in the mudline sample. Just below the seafloor, concentrations increase to $12.0 \mathrm{mM}$ at $1.45 \mathrm{~m}$ CSF-A (Table T10). K concentrations generally increase deeper than this depth, such that they reach $12.8 \mathrm{mM}$ at $71.55 \mathrm{~m}$ CSF-A. From this depth, $\mathrm{K}$ concentrations decrease steadily to the bottom of the hole, reaching $10.1 \mathrm{mM}$ at $\sim 242 \mathrm{~m}$ CSF-A.

The increase in $\mathrm{K}$ concentrations immediately below the seafloor exists at all sites drilled during Expedition 346 and may reflect a temperature effect or cat- ion exchange during authigenic mineral formation. The decrease in $\mathrm{K}$ with depth perhaps results from further reactions with ash and basalt (Murray et al., 1992).

\section{Boron and lithium}

At the mudline, B concentrations are $410 \mu \mathrm{M}$ in Hole U1430A and $422 \mu \mathrm{M}$ in Hole U1430B (Table T10; Fig. F39). The Rhizon samples show that B concentrations increase to $567 \mu \mathrm{M}$ at $0.99 \mathrm{~m}$ CSF-A and remain near that concentration until $5.04 \mathrm{~m}$ CSF-A. Deeper than $5.04 \mathrm{~m}$ CSF-A, B begins to decrease to $467 \mu \mathrm{M}$ at $7.32 \mathrm{~m}$ CSF-A. The deeper B profile shows scatter but an overall decrease with depth to $453 \mu \mathrm{M}$ at 242 m CSF-A. B may be affected by pH at depth.

Li concentrations at the mudline are $25 \mu \mathrm{M}$ in Hole U1430A and $27 \mu \mathrm{M}$ in Hole U1430B. Li concentrations increase steadily and reach a maximum of 254 $\mu \mathrm{M}$ in the deepest sample at $241.55 \mathrm{~m}$ CSF-A. The Li profile shares some similarities with the Si profile, including inflection points at $33.55,81.05$, and 194.45 m CSF-A.

\section{Silica}

Dissolved Si concentrations were measured by inductively coupled plasma-atomic emission spectroscopy (ICP-AES). Although these values are not as precise as $\mathrm{H}_{4} \mathrm{SiO}_{4}$ concentrations determined using the spectrophotometer, comparative results at other sites during Expedition 346 suggest that this approach renders a fairly accurate $\mathrm{Si}$ profile. Si concentrations in the mudline samples are $175 \mu \mathrm{M}$ in Hole U1430A and $302 \mu \mathrm{M}$ in Hole U1430B. Immediately below the seafloor (0.05-1.34 m CSF-A), Si concentrations fluctuate between 490.06 and $781.22 \mu \mathrm{M}$. Overall, however, Si concentrations steadily increase downhole, almost reaching $1300 \mu \mathrm{M}$ in the deepest sample (241.55 m CSF-A) (Fig. F39). There are hints in the sedimentary sequence at the deepest depth of opalCT (see "Lithostratigraphy"), although the lack of a precipitous decline in dissolved silica suggests that the opal-A/opal-CT boundary was not penetrated at this site (Kastner et al., 1977).

\section{Chlorinity and sodium}

Chloride and $\mathrm{Na}$ concentrations are 545 and 468 $\mathrm{mM}$, respectively, in the mudline sample from Hole U1430A, which compare to 551 and $473 \mathrm{mM}$, respectively (Table T10; Fig. F40), in inferred JSPW (see "Geochemistry" in the "Methods" chapter [Tada et al., 2015b]). Interstitial water concentrations of both elements decrease significantly over the upper $50 \mathrm{~m}$ 
below the seafloor and return to concentrations similar to bottom water over the next $185 \mathrm{~m}$. Less saline water in shallowly buried sediment is a common theme across the marginal sea.

\section{Bromide}

$\mathrm{Br}^{-}$concentrations of the mudline samples are 0.83 and $0.81 \mathrm{mM}$ in Holes U1430A and U1430B, respectively. These values bracket the $82 \mathrm{mM}$ expected for JSPW (see "Geochemistry" in the "Methods" chapter [Tada et al., 2015b]). Below the seafloor, $\mathrm{Br}^{-}$concentrations range between 0.82 and $0.85 \mathrm{mM}$ for the entire sequence (Table T10; Fig. F40). Thus, unlike all sites previously drilled during Expedition 346, there is a complete disconnect between $\mathrm{Br}^{-}$, alkalinity, and $\mathrm{NH}_{4}{ }^{+}$concentrations. Bromide concentrations are essentially the same as bottom water at Site U1430 because there is very little organic matter diagenesis.

\section{Preliminary conclusions}

Site U1430 ended up being a challenging site to analyze at the end of a cruise with little time before reaching the final port call. It is perhaps the most intriguing site drilled during Expedition 346. All evidence suggests that Fe sulfide oxidation operating in an unexpected environment - the base of an in situ organic-rich marine sediment sequence. This would require a deep source of $\mathrm{O}_{2}$ to the sediment. One possibility is that water carrying oxygen is flowing along porous diatom horizons or along the sediment/acoustic basement interface. Additionally, water could flow through a thick ash and sand layer in the deepest part of the sequence.

\section{Paleomagnetism}

\section{Paleomagnetic samples and measurements}

Paleomagnetic investigations at Site U1430 included measurement of magnetic susceptibility of wholecore and archive-half split-core sections and natural remanent magnetization (NRM) of archive-half sections. NRM was measured before and after alternating field (AF) demagnetization with a $20 \mathrm{mT}$ peak field for archive-half sections of APC-collected Cores 346-U1430A-1H through $28 \mathrm{H}$ at $5 \mathrm{~cm}$ intervals. NRM of archive-half sections of APC Cores 346U1430B-1H through 28H and APC Cores 346U1430C-1H through $22 \mathrm{H}$ was measured only after $20 \mathrm{mT}$ AF demagnetization at $5 \mathrm{~cm}$ intervals. The FlexIT core orientation tool (see "Paleomagnetism" in the "Methods" chapter [Tada et al., 2015b]) was used to orient APC Cores 346-U1430A-2H through
$25 \mathrm{H}$. The APC core orientation data for Hole U1430A are reported in Table T13.

We collected a total of 29 paleomagnetic discrete cube samples (see "Paleomagnetism" in the "Methods" chapter [Tada et al., 2015b]) from Cores 346U1430A-1H through $28 \mathrm{H}$ and $32 \mathrm{X}$. The discrete samples were typically taken from the first section of each core and occasionally from other sections of the cores (triangles in Fig. F41A, F41B). Stepwise AF demagnetization on 28 discrete samples (orange triangles in figure) collected from Hole U1430A was performed at successive peak fields of $0,5,10,15,20$, $25,30,40,50$, and $60 \mathrm{mT}$ to verify the reliability of the split-core measurements and to determine the demagnetization behavior of the recovered sediment. Following each demagnetization step, NRM of the discrete samples was measured with the samples placed in the "top-toward" or "+Z-axis toward magnetometer" orientation (see "Paleomagnetism" in the "Methods" chapter [Tada et al., 2015b]) on the discrete sample tray.

We processed data extracted from the shipboard Laboratory Information Management System (LIMS) database by removing all measurements collected from disturbed and void intervals and all measurements that were made within $10 \mathrm{~cm}$ of the section ends, which are slightly biased by measurement edge effects. For declination data from cores in Hole U1430A where FlexIT tool data are available, we corrected the declination values for each core using the estimated orientation angles. A modified version of the UPmag software (Xuan and Channell, 2009) was used to analyze the NRM data of both the split-core section and the discrete cube samples. The disturbed and void intervals used in this process are reported in Table T14. The processed NRM inclination, declination, and intensity data after $20 \mathrm{mT}$ AF demagnetization are reported in Table T15 and shown in Figure F41.

\section{Natural remanent magnetization and magnetic susceptibility}

NRM intensity after $20 \mathrm{mT}$ AF demagnetization in the three measured holes at Site U1430 is similar in magnitude for overlapping intervals, mostly ranging between $\sim 10^{-5}$ and $10^{-2} \mathrm{~A} / \mathrm{m}$. For the uppermost $\sim 40$ $\mathrm{m}$ of the recovered sediments from Holes U1430A and U1430B, NRM intensity of the measured core sections after $20 \mathrm{mT}$ demagnetization is mostly on the order of $10^{-3} \mathrm{~A} / \mathrm{m}$ and occasionally reaches $10^{-2}$ $\mathrm{A} / \mathrm{m}$. Between $\sim 40$ and $\sim 60 \mathrm{~m}$ CSF-A, NRM intensity decreases downcore from $10^{-3} \mathrm{~A} / \mathrm{m}$ to $\sim 10^{-5} \mathrm{~A} / \mathrm{m}$. Deeper than $\sim 60 \mathrm{~m}$ CSF-A until the bottom of the 
holes, NRM intensity is low and mostly on the order of $10^{-5}$ to $10^{-4} \mathrm{~A} / \mathrm{m}$. The low NRM intensity deeper than $\sim 60 \mathrm{~m}$ CSF-A is accompanied by large scatter in paleomagnetic direction. For many measured cores, NRM intensity near the top part of the cores appears to show high intensity that gradually decreases downcore to about average values of the cores within $\sim 1 \mathrm{~m}$. We think this is most likely related to stronger drilling overprints in the upper part of the cores.

The AF demagnetization behavior of the 28 measured discrete samples is illustrated in Figure F42. Declination and inclination values acquired from the discrete sample measurement generally agree well with the split-core measurement after $20 \mathrm{mT}$ AF demagnetization. All samples exhibit a steep, normal overprint that was generally removed after AF demagnetization at peak fields of $\sim 15-20 \mathrm{mT}$, demonstrating that the $20 \mathrm{mT}$ AF demagnetization is, in general, sufficient to eliminate the drilling overprint. Discrete samples from the top $\sim 30 \mathrm{~m}$ of Hole U1430A show well-defined component directions with positive inclinations (Fig. F42A-F42D). For measured discrete samples from deeper than $\sim 30 \mathrm{~m}$ CSF-A, NRM intensity before and after stepwise AF demagnetization is about one or two magnitudes lower than that from shallower than $\sim 30$ m CSF-A. NRM measurements of discrete samples from the greater depth with weak intensity often appear to have lower coercivity and are affected by an anhysteretic remanent magnetization (ARM), possibly acquired because of bias caused by ambient magnetic field during demagnetization.

Magnetic susceptibility measurements were taken on whole cores from all holes as part of the WholeRound Multisensor Logger (WRMSL) analysis and on archive-half sections using the Section Half Multisensor Logger (SHMSL) (see "Physical properties"). The WRMSL acquired susceptibility was stored in the database in raw meter units. These were multiplied by a factor of $0.68 \times 10^{-5}$ to convert to the dimensionless volume SI unit (Blum, 1997). A factor of (67/ $80) \times 10^{-5}$ was multiplied by the SHMSL acquired susceptibility stored in the database. Magnetic susceptibility measurement is consistent between the two instruments and across the different holes for overlapping intervals and varies mostly between $1 \times$ $10^{-5}$ and $20 \times 10^{-5}$ SI (Fig. F41, fourth panel). For the uppermost $\sim 60 \mathrm{~m}$ of the recovered sediment, magnetic susceptibility is generally close to $10 \times 10^{-5} \mathrm{SI}$. Deeper than $\sim 60 \mathrm{~m}$ CSF-A until the bottom of the holes, magnetic susceptibility largely varies between $\sim 1 \times 10^{-5}$ and $10 \times 10^{-5}$ SI. Magnetic susceptibility of sediment in all holes, in general, mimics NRM intensity, suggesting that the magnetic minerals that carry
NRM are the same or at least coexist with those that dominate magnetic susceptibility.

\section{Magnetostratigraphy}

Paleomagnetic inclination and declination data of the holes show patterns that allow for the determination of magnetic polarity for at least the uppermost $\sim 40 \mathrm{~m}$ of recovered sediment. Both magnetic declination and inclination after $20 \mathrm{mT} \mathrm{AF} \mathrm{demag-}$ netization were used when possible for the magnetostratigraphic interpretation at Site U1430. The geomagnetic field at the latitude of Site U1430 $\left(37.90^{\circ} \mathrm{N}\right)$ has an expected inclination of $57.29^{\circ}$, assuming a geocentric axial dipole field model, which is sufficiently steep to determine magnetic polarity in APC cores that lack horizontal orientation. We identified the Brunhes/Matuyama (B/M) boundary (0.781 Ma) at $\sim 33.5 \mathrm{~m}$ CSF-A in Hole U1430A, $\sim 34 \mathrm{~m}$ CSF-A in Hole U1430B, and $\sim 37 \mathrm{~m} \mathrm{CSF-A} \mathrm{(where} \mathrm{close} \mathrm{to}$ slump are found) in Hole U1430C (Table T16).

Above the identified $\mathrm{B} / \mathrm{M}$ boundary, inclinations after $20 \mathrm{mT}$ AF demagnetization from all three holes vary around the expected normal polarity dipole inclination at Site U1430. In Hole U1430A, the FlexITcorrected declinations (green dots in Fig. F41A) are mostly stable and vary around $0^{\circ}$ or $360^{\circ}$. Right below the $\mathrm{B} / \mathrm{M}$ boundary, inclinations from both holes are apparently dominated by shallow and negative values. The interpreted $\mathrm{B} / \mathrm{M}$ boundary is consistent with the stepwise demagnetization data from the measured discrete samples. Discrete samples from above the boundary (Fig. F42A-F42D) show well-defined characteristic remanence with positive inclinations, whereas discrete samples from right below the B/M boundary (Fig. F42E) apparently have negative inclinations at high demagnetization steps. The depth level of the B/M boundary in Hole U1430A agrees well with many of the identified biostratigraphic events (see "Biostratigraphy").

Below the B/M boundary, NRM intensity of the sediment after $20 \mathrm{mT}$ AF demagnetization is generally weak and on the order of $10^{-5}$ to $10^{-4} \mathrm{~A} / \mathrm{m}$, whereas NRM inclination and declination after $20 \mathrm{mT}$ demagnetization show large scatter. The weak NRM intensity, increased coring disturbance, strong drill string overprint, and the large scatter in paleomagnetic declinations makes magnetostratigraphic interpretations difficult for the deep part of sediments recovered at Site U1430.

\section{Physical properties}

Physical properties measurements at Site U1430 were conducted to provide high-resolution data on the 
bulk physical properties and their downhole variations in Holes U1430A-U1430C. After the sections reached thermal equilibrium with the ambient room temperature of $\sim 20^{\circ} \mathrm{C}$, thermal conductivity (one per core) and NGR measurements (eight per full section) completed the suite of whole-core measurements. One half of each split core was reserved for archiving and the other half was for analysis and sampling (working half). Shear stress measurements were performed (most commonly one per core) from 0 to 240 $\mathrm{m}$ CSF-A on the working halves of Hole U1430A. Moisture and density (MAD) measurements were performed on discrete core samples (most commonly one or two per core) collected from the working halves of Hole U1430A. Diffuse spectral reflectance (most commonly at 2 or $5 \mathrm{~cm}$ intervals) and point magnetic susceptibility (most commonly at 2 or 5 $\mathrm{cm}$ intervals) were measured using the SHMSL on the archive halves. Physical properties measurements are presented synthetically in Figures F43, F44, F45, F46, and F47.

\section{Thermal conductivity}

Thermal conductivity was measured once per core using the full-space probe, usually near the middle of Section 4 . Overall, thermal conductivity values range from 0.82 to $1.11 \mathrm{~W} /(\mathrm{m} \cdot \mathrm{K})$ without a clear increasing trend with depth. However, thermal conductivity follows porosity and gamma ray attenuation (GRA) bulk density, and thus, in part, lithology. In general, thermal conductivity values are high (0.97$1.11 \mathrm{~W} /[\mathrm{m} \cdot \mathrm{K}]$ ) in lithologic Unit I and Subunit IIA (shallower than $73.1 \mathrm{~m}$ CSF-A for Hole U1430A) and low $(0.82-0.91 \mathrm{~W} /[\mathrm{m} \cdot \mathrm{K}])$ in lithologic Subunits IIB and IIIA (deeper than $73.1 \mathrm{~m}$ CSF-A for Hole U1430A). Some positive peaks with values of $\sim 1.00$ $\mathrm{W} /(\mathrm{m} \cdot \mathrm{K})$ occur in Subunit IIIA with similar values to lithologic Unit I and Subunit IIA.

\section{Moisture and density}

Although measurement errors exist in GRA bulk density data because of the presence of air between a core and a core liner, in general, GRA bulk density tends to reflect the characteristic of each lithology (Fig. F43; see "Lithostratigraphy"). GRA bulk density at Site U1430 is largely similar in pattern to Site U1425 for Subunits IA, IB, and IIA (Fig. F44). Such similarity is not kept for Subunits IIB and IIIA because of a potential hiatus within lithologic Subunit IIB at Site U1430 (see "Biostratigraphy"). GRA bulk density is highly variable in the uppermost part (between 0 and $57 \mathrm{~m}$ CSF-A) coinciding with lithologic Unit I, with values ranging from 1.2 to $1.7 \mathrm{~g} / \mathrm{cm}^{3}$ (Fig. F43). As at previous sites, high GRA bulk den- sity values and variability predominate in Unit I, reflecting alternating very dark brown to black organic-rich and lighter olive and green hemipelagic sediment. GRA bulk density values sharply drop at the lithologic Unit I/II boundary, and then increase gradually downhole in Subunit IIA, reaching maximum values $\left(1.6 \mathrm{~g} / \mathrm{cm}^{3}\right)$ around $\sim 75 \mathrm{~m}$ CSF-A before decreasing to $\sim 1.3 \mathrm{~g} / \mathrm{cm}^{3}$ within lithologic Subunit IIB. GRA bulk density values remain low and stable between 82 and 157 m CSF-A (Subunit IIB) with a slight overall increase downhole. After a small step decrease and increase between 157 and 170 m CSF-A, GRA bulk density gradually decreases with depth to $\sim 230 \mathrm{~m}$ CSF-A with relatively low scatter. These changes of GRA bulk density in Subunit IIIA are probably related to alternation between clay-rich and biogenic component (mainly nannofossil and diatom)-rich sediments (see "Lithostratigraphy"). Relatively lower bulk density values dominate in biogenic component-rich sediment layers. From $230 \mathrm{~m}$ CSF-A to the bottom of the hole, GRA bulk density increases abruptly, and the highest value (up to $1.8 \mathrm{~g} / \mathrm{cm}^{3}$ ) of GRA bulk density occurs at $\sim 250$ m CSF-A. These abrupt changes of GRA bulk density between $\sim 230$ and $\sim 250$ m CSF-A may reflect the diagenetic transition from opal-A to opal-CT, which defines Subunit IIIA/IIIB boundary for Sites U1430 and U1425 (Fig. F44). This transition was also confirmed by XRD (see "Lithostratigraphy"). The GRA bulk density trends at Site U1430 correlate well with density log acquired in open Hole U1430B with the exception of the bottom part of the hole (see Fig. F49 and "Downhole measurements").

Although discrete wet bulk density and grain density are relatively constant for the entire core interval, ranging from 1.2 to $1.7 \mathrm{~g} / \mathrm{cm}^{3}$ and from 2.3 to $2.8 \mathrm{~g} / \mathrm{cm}^{3}$, respectively, the primary trends agree well with GRA bulk density (Fig. F45). Porosity and water content show generally reversed trends when compared to density, ranging from $59.4 \%$ to $84.6 \%$ and from $35.5 \%$ to $70.0 \%$, respectively. Discrete bulk density and grain density increase with depth in Subunit IA (decrease in porosity and water content) similar to GRA bulk density. Subsequently, discrete bulk density and grain density generally decrease with depth to $\sim 230 \mathrm{~m}$ CSF-A, where porosity and water content of the sediment increase. These decreases in bulk density and increase in porosity and water content with depth, which is contrary to the typical trends in marine sediment, are closely related to the downward increase in diatom silica as discussed at Sites U1424 and U1425. At $245 \mathrm{~m}$ CSF-A, coinciding with the Subunit IIIA/IIIB boundary, discrete bulk density, ranging between 1.2 and $1.5 \mathrm{~g} / \mathrm{cm}^{3}$ in Sub- 
unit IIIA, increases rapidly to $1.7 \mathrm{~g} / \mathrm{cm}^{3}$, whereas porosity and water content show large step decreases of $15.1 \%$ and $19.4 \%$, respectively.

\section{Magnetic susceptibility}

Whole-core magnetic susceptibility values Site U1430 are consistently low downhole typically below $10 \times 10^{-5} \mathrm{SI}$, with the exception of several high magnetic susceptibility values in Unit I (Fig. F43). Although magnetic susceptibility at Site U1430 shows low variability, the downhole trend agrees well with GRA bulk density and varies with lithologic changes. Point magnetic susceptibility from the SHMSL closely tracks whole-core magnetic susceptibility, with mean values for the site between 0 and $15 \times 10^{-5} \mathrm{SI}$. High magnetic susceptibility peaks in Unit I agree well with the depth of tephra/ash layers (see "Lithostratigraphy") due to highly magnetic authigenic minerals within tephra/ash layers. Low magnetic susceptibility remains stable in Units II and III, with relatively less scatter, and then also with large increases at the Subunit IIIA/IIIB boundary. This may be related to the diatom ooze/diatom-rich clay being replaced by siliceous claystone at the bottom of Subunit IIIA and the top of Subunit IIIB (see "Lithostratigraphy").

\section{Natural gamma radiation}

NGR shows strong cyclicity that is similar to the GRA bulk density cyclicity (see also "Downhole measurements"). As these conformable variation patterns with GRA bulk density suggest that their controls are closely related, NGR also shows the trend pattern of lithologic changes, alternating between very dark brown to black organic-rich bands and lighter olive to green hemipelagic sediment. Between 0 and $8 \mathrm{~m}$ CSF-A, the total NGR counts show a large step increase from 20 to $55 \mathrm{cps}$ and then a gradual increase to $\sim 45 \mathrm{~m}$ CSF-A (Fig. F43). This coincides with the Subunit IA/IB boundary, with strong cyclicity. As discussed at previous sites, these variation patterns of NGR may be explained by high uranium content associated with organic-rich layers in Unit I. After sharply decreasing at $58 \mathrm{~m}$ CSF-A, which corresponds to the Unit I/II boundary, NGR counts increase and then decrease again between 58 and $82 \mathrm{~m}$ CSF-A. Deeper, NGR gradually increases to $157 \mathrm{~m}$ CSF-A. Subsequently, NGR counts generally decrease to $230 \mathrm{~m}$ CSF-A and then increase from 10 to $70 \mathrm{cps}$ between $\sim 230$ and $\sim 250$ m CSF-A.

\section{Compressional wave velocity}

Compressional $P$-wave velocity was measured with the WRMSL in Sections 1, 2, and 3 of each core for
Holes U1430A-U1430C and then combined as one data set of values for this site. $P$-wave velocity at Site $\mathrm{U} 1430$ varies from 1488 to $1726 \mathrm{~m} / \mathrm{s}$ (average $=1540$ $\mathrm{m} / \mathrm{s}$ ) and generally increases with depth. The trend, however, is not clear enough to reflect the lithologic changes because of the lack of a data set for the entire site. In Unit I and Subunit IIA, high $P$-wave velocity is related to coarser grained tephra/ash layers.

\section{Vane shear stress}

Shear stress measurements were performed (generally one per core) from 0 to $240 \mathrm{~m}$ CSF-A on the working halves of Hole U1430A using an analog vane shear device. Shear strength ranges from 6.3 to $192.1 \mathrm{kPa}$ and generally increases with depth (Fig. F45). Between 0 and $\sim 50 \mathrm{~m}$ CSF-A, shear strength linearly increases from 6.3 to $38.2 \mathrm{kPa}$, and shear strength values show relatively high scatter with an overall increase to $180 \mathrm{~m}$ CSF-A. Deeper, shear strength linearly decreases to $15 \mathrm{kPa}$ and then largely increases to its maximum. This scattering shear strength in the lower part of the hole may be related to the highly diatomaceous layers or microfractures within cores.

\section{Diffuse reflectance spectroscopy}

Color reflectance data measured on the split archivehalf sections at Site U1430 are little different from previously drilled Site U1425 (Fig. F46). Although there is high variability, reflecting the lithologic change alternating between very dark brown to black organic-rich bands and lighter olive to green hemipelagic sediment, occurring in the physical properties within Unit I, the cyclicity of color reflectance at Site U1430 is much weaker than at Site U1425. Below Subunit IIA, color reflectance remains stable to the bottom of the hole, whereas the color bands fade out downhole below Unit I. The trend of luminance $\left(\mathrm{L}^{*}\right)$ in this interval is much lower than the trend at Site U1425. Because of this, although Site U1425 shows higher variability in Unit I, the mean value of $L^{*}$ at Site U1430 (average $=31.5$ ) is lower than Site U1425 (average $=34.0$ ) (Fig. F47). This indicates that Site U1430 consists of more dark colored sediment. Parameters $\mathrm{a}^{*}$ and $\mathrm{b}^{*}$ combined show the variable presence of primarily yellowishblueish compounds.

\section{Summary}

Physical properties measured at Site U1430 generally show trends that are similar to Site U1425 for Subunits IA, IB, and IIA, following sediment lithology. Magnetic susceptibility, bulk density, and NGR have higher values in Unit I than in Unit II, whereas po- 
rosity and water content show opposite trends. Magnetic susceptibility and $P$-wave velocity also show high peak values, which agrees well with the depth of tephra/ash layers in Unit I. Shear strength generally increases to $\sim 180 \mathrm{~m}$ CSF-A with depth because of sediment compaction, then decreases to $\sim 230 \mathrm{~m}$ CSF-A, and finally shows a large increase between $\sim 230$ and $\sim 240 \mathrm{~m}$ CSF-A. Color reflectance shows higher variation in physical properties in Unit I than in Unit II, and the variations are closely related to the lithology of Unit I, which consists of alternating very dark brown to black organic-rich bands and lighter olive to green hemipelagic sediment. All physical property values exhibit a large change at $\sim 240 \mathrm{~m}$ CSF-A, which is assumed as the opal-A/opalCT boundary transition zone.

\section{Downhole measurements}

\section{Logging operations}

Downhole logging measurements at Site U1430 were conducted in Hole U1430B after completion of APC/ $\mathrm{XCB}$ coring to a total depth of $275 \mathrm{~m}$ CSF-A. In preparation for logging, the hole was flushed with a $114 \mathrm{bbl}$ sweep of high-viscosity mud, and the bit was pulled up to 80 mbsf. The wireline logging tool strings were modified to maximize data acquisition in the lowest part of the hole. Two short modified paleo combo and Formation MicroScanner (FMS)sonic tool strings were deployed to the bottom of Hole U1430B (Fig. F48) (see "Downhole measurements" in the "Methods" chapter [Tada et al., 2015b], see also Table T12 in the "Methods" chapter [Tada et al., 2015b] for tool acronyms).

On 19 September 2013 at $1830 \mathrm{~h}$ (UTC), the paleo combo tool string (comprising natural and spectral gamma radiation, density, and magnetic susceptibility tools) descended from the rig floor into the pipe. A downlog was taken at $\sim 600 \mathrm{~m} / \mathrm{h}$ to the bottom of the hole at $271.6 \mathrm{~m}$ WSF. The hole was logged up to $\sim 191 \mathrm{~m} \mathrm{WSF}$ at $500 \mathrm{~m} / \mathrm{h}$ (Pass 1 ). The tool string returned for a main pass from the bottom of the hole to the seafloor.

The second tool string included resistivity at the top and natural and spectral gamma radiation at the bottom. Data are uncorrected from borehole diameter. The tool string started down the pipe at $2250 \mathrm{~h}$. The downlog was run at a logging speed of $500 \mathrm{~m} / \mathrm{h}$ to the bottom of the hole at $271.5 \mathrm{~m}$ WSF. The repeat uplog (Pass 1) was done at a logging speed of $500 \mathrm{~m} / \mathrm{h}$ up to $\sim 170.5 \mathrm{~m}$ WSF. The tool string returned for a main pass from the bottom of the hole to the seafloor.
The FMS-sonic was rigged at $\sim 0200 \mathrm{~h}$ on 20 September. A downlog was taken at $600 \mathrm{~m} / \mathrm{h}$. The tool string reached the bottom of Hole U1430B at $\sim 271.7 \mathrm{~m}$ WSF. Two uphole passes of the FMS-sonic were run, the first pass to $\sim 75 \mathrm{~m} \mathrm{WSF}$ and the main pass to the seafloor, both at $550 \mathrm{~m} / \mathrm{h}$. The first pass was conducted normally up to $114 \mathrm{~m}$ WSF, at which point the surface system indicated a telemetry drop-out. There is a small interval on the first pass from 113.8 to $111.3 \mathrm{~m}$ WSF where the FMS readings are not valid. The main pass was conducted without any disruption, providing data over the entire interval of interest without any gaps. The FMS-sonic tool string was back to the surface at $0525 \mathrm{~h}$. Rig down was finished by $0700 \mathrm{~h}$, concluding logging operations at Site U1430.

The seafloor depth was indicated by the step in the gamma logs. The paleo combo uplogs (main passes) found the seafloor at 1081.30 and $1081.55 \mathrm{mbrf}$, and the main pass of the FMS-sonic found the seafloor at 1081.60 mbrf. Heave was very low $(<0.2 \mathrm{~m}$ peak-topeak) during operations, and the wireline heave compensator was not used (see "Downhole measurements" in the "Methods" chapter [Tada et al., 2015b]).

\section{Logging data quality}

Tool calibration was performed both before and after the logging runs to ensure quality control. In Hole U1430B, the borehole conditions were of medium quality with a diameter $<12.5$ inches from 100 to 152 mbsf and deeper than 250 mbsf (Fig. F49, Column 1). The borehole is slightly larger from the pipe entrance to $100 \mathrm{mbsf}$, although it did not exceed $\sim 14$ inches in diameter. The diameter is noticeably enlarged from 168 to 257 mbsf, which impacted FMS image quality, especially from $\sim 168$ to $\sim 190$ mbsf. The borehole diameter is also asymmetrical, as evidenced from FMS calipers (Fig. F50, Column 1). Heave was negligible during downhole logging data acquisition, and despite the moderate borehole quality, $\log$ data quality is generally very good.

There is good agreement between physical properties and logging data for the NGR and density logs along almost the entire borehole depth (Fig. F49, Columns 2 and 3). As a result of caliper closure (see "Downhole measurements" in the "Site U1423" chapter [Tada et al., 2015d]), the uplog gamma rays from the first tool string and the FMS-sonic deviate from the core NGR data to lower values from $\sim 85$ and $\sim 103$ mbsf to the pipe entrance (Fig. F49, Column 2). For the same reason, the density log shows lower values than the core data over the same interval (shallower than $~ 85$ mbsf). The second tool string was run cen- 
tralized in the borehole, so the gamma ray uplog is not affected by this phenomenon, although in the absence of the caliper measurements the data are not corrected from borehole diameter. As the total spectral gamma ray (HSGR) tool was located at the bottom of the tool string during the second run, the recorded data cover a longer interval (Fig. F50, Column 2). For the three tool strings, natural and spectral gamma ray data recorded shallower than 80 mbsf should only be used qualitatively because of the attenuation of the signal through the pipe (Figs. F49, F50).

The resistivity curves are good, except for some highfrequency noise starting from $\sim 120$ mbsf to the pipe entrance. Preprocessing has been applied to correct the logs of the Magnetic Susceptibility Sonde from temperature drift (see "Downhole measurements" in the "Site U1423" chapter [Tada et al., 2015d]). The corrected deep-reading, low-resolution log is generally inversely correlated with the density log (Fig. F49, Column 5). The drift-corrected, high-resolution log correlates relatively well with the magnetic susceptibility measurements on cores, except where affected by borehole size and borehole wall rugosity. Further processing remains necessary. The velocity $\log$ has a steadily increasing downhole trend and correlates well with the density log deeper than $\sim 245$ mbsf. The sonic quality may have been impacted by the enlarged borehole diameter shallower than 105 mbsf and from $\sim 200$ to $\sim 245$ mbsf. The FMS resistivity images were of very good quality, except for some short intervals where the borehole diameter was enlarged with high-frequency changes in diameter (Fig. F50, Column 6).

\section{Logging unit}

The Hole U1430B logs change gradually downhole, with no major steps in base levels. The entire logged interval was divided in two logging units (LI and LII; Fig. F49). The upper part of the hole (from below the pipe to $\sim 244$ mbsf) is characterized by lower gamma ray, density, and resistivity than the bottom part of the hole. Hole U1430B is characterized by moderateamplitude variability in NGR (and its $\mathrm{U}, \mathrm{Th}$, and $\mathrm{K}$ components) on a decameter to submeter scale (Fig. F50). The Hostile Environment Natural Gamma Ray Sonde (HNGS) signal ranges on average from 20 to 90 gAPI and most likely tracks clay content (Fig. F49). The $U$, Th, and $K$ curves are generally well correlated (Fig. F50). The $\mathrm{U}$ content varies from 1 to 10 ppm on the data set uncorrected from borehole diameter (Fig. F50, Column 5). The gamma ray signal correlates well with the bulk density log, which shows high-amplitude variations ranging from 1.20 to $2.1 \mathrm{~g} / \mathrm{cm}^{3}$ (Fig. F50, Column 2). Resistivity and sonic logs are relatively flat, except deeper than $\sim 244$ mbsf where they show pronounced oscillations of varied amplitude and frequency, which are well correlated with the density logs. Sonic velocity ranges from 1.5 to $2.3 \mathrm{~km} / \mathrm{s}$.

\section{Logging Unit LI: base of drill pipe ( $~ 80 \mathrm{mbsf})$ to $\sim 244$ mbsf}

Logging Unit LI is characterized by moderate-amplitude variability in NGR (and its $\mathrm{U}$, Th, and K components) (Fig. F50). Terrigenous clay has high $\mathrm{K}$ and Th contents and has relatively higher density and lower porosity than diatom-rich sediment. As a consequence, intervals with high gamma ray values, high density, and high resistivity generally reflect an increase in terrigenous clay content relative to diatomrich intervals (see "Lithostratigraphy"). Conversely, the intervals with gamma ray, density, and resistivity low values correlate in cores with diatom-rich intervals (see "Lithostratigraphy"). Logging Unit LI has been divided into two subunits on the basis of changes in character of the downhole logs (logging Subunits LIa and LIb; Figs. F49, F50).

\section{Logging Subunit Lla: base of drill pipe ( $\sim 80 \mathrm{mbsf})$ to $\sim 200 \mathrm{mbsf}$}

Logging Subunit LIa is characterized by NGR $>30$ gAPI and moderate- to high-amplitude swings in U, Th, and K. A slight downhole increasing trend is also observed, which likely reflects a downhole decrease in diatom content relative to terrigenous sediment (Fig. F50). Two low value intervals are observed at $\sim 94$ and $~ 98$ mbsf, with the deepest approximating the depth of the lithologic Unit II/III boundary, placed at $98.10 \mathrm{~m}$ CSF-A in Hole U1430A (Section 346-U1430A-11H-7) (see "Lithostratigraphy"). The gamma ray signal correlates well with the bulk density $\log$, which shows high-amplitude variations ranging from 1.20 to $1.50 \mathrm{~g} / \mathrm{cm}^{3}$ (Figs. F49 [Column $1]$, F50). The peak value $>1.60 \mathrm{~g} / \mathrm{cm}^{3}$ ( 142 mbsf) does not correlate with anything obvious in the cored sediment. The sonic and resistivity curve shows low-amplitude variations. Logging Subunit LIa extends over the lower part of lithologic Subunit IIB (diatom ooze with a few silty clay intervals) and part of Subunit IIIA (alternating layers of heavily bioturbated diatomaceous ooze and diatom-rich/bearing silty clay).

The transition from logging Subunit LIa to LIb is placed at $\sim 200$ mbsf. No noticeable change in lithology was observed at this depth (see "Lithostratigraphy").

\section{Logging Subunit Llb: 200 to $\sim 244$ mbsf}

Logging Subunit LIb is distinguished from logging Subunit LIa by a decrease in resistivity values. This subunit is also characterized by higher frequency os- 
cillations in total and spectral natural gamma radiation compared to logging Subunit LIa (Fig. F50). A downhole decreasing trend in the total gamma ray counts (and in $\mathrm{U}, \mathrm{Th}$, and $\mathrm{K}$ ) is also observed to $\sim 230$ mbsf, which is the depth at which the lowest values at the scale of the borehole are reached. A downhole increasing trend is observed deeper than this depth. The density curve follows the same trends with values ranging from 1.2 to $1.5 \mathrm{~g} / \mathrm{cm}^{3}$ (Fig. F49, Column 3 ), with a minimum density observed at $\sim 231 \mathrm{mbsf}$. This low density, low gamma ray interval is $\sim 4 \mathrm{~m}$ thick and correlates with a thick laminated diatom ooze-rich interval in Core 346-U1430B-25H (see "Lithostratigraphy").

Logging Subunit LIb extends over the lower part of lithologic Subunit IIIA. The base of logging Subunit LIb ( 244 mbsf) fits the depth of the lithologic Subunit IIIA/IIIB boundary placed at $244 \mathrm{~m}$ CSF-A in Section 346-U1430B-28H-1 (see "Lithostratigraphy").

\section{Logging Unit LII: $\sim 244$ to $\sim 272$ mbsf}

Logging Unit LII starts with a sharp increase in density, resistivity, and sonic log values (Fig. F49). Highamplitude swings are observed in these logs at a scale varying from one to few meters in thickness, reflecting the interbedded gravel, sandstone, diatom ooze, and tephras observed within lithologic Subunit IIIB and Unit IV (see "Lithostratigraphy"). Logging Unit LII is also distinguished from logging Unit LI by higher values in total NGR and especially in components $\mathrm{Th}$ and $\mathrm{K}$. The high $\mathrm{K}$ concentrations reflect the presence of glauconite in the sediment.

\section{FMS images}

In Hole U1430B, as observed at previous Expedition 346 sites, conductive intervals (dark color in the FMS image in Fig. F50) generally correlate with low gamma ray, low density, and low resistivity logs. Conversely, more resistive intervals (light color in the FMS image in figure) generally correlate with higher values in the gamma ray, bulk density, and resistivity logs. This relationship can be interpreted in terms of the relative abundance of clay/diatom in the sediment, with clay having higher $\mathrm{K}$ and Th contents and relatively greater density than diatom-rich sediment. With the exception of ash, gravel, and indurated layers, conductive intervals in the FMS images tend to reflect intervals enriched in diatoms, whereas resistive intervals reflect relatively high terrigenous clay content. The good FMS resistivity data quality allows the borehole formation resistivity to be interpreted at several scales.
At the scale of the borehole, the interval shallower than 200 mbsf (logging Subunit LIa) is characterized by (relatively) medium conductivity (orangecolored upper interval in the FMS image in Fig. F50). Higher conductivity (dark color in the FMS image) is observed deeper, within logging Subunit LIb. This is interpreted as reflecting a possible increase in diatom content within the lower part of lithologic Subunit IIIA (see "Lithostratigraphy") compared to the upper part of the subunit. Deeper than 240 mbsf, the FMS images are characterized by high resistivity (light colors in the FMS image in figure), which reflects the increase in clay content in lithologic Subunit IIIB and Unit IV (see "Lithostratigraphy") as well as the presence of cemented intervals evidenced by high density, velocity, and resistivity values (Fig. F49, Columns 3, 4, and 6).

At a finer scale, the FMS images also reveal numerous resistive and conductive intervals, with thicknesses ranging from several tens of centimeters to a few meters (Figs. F51, F52). Transitions between alternations are mainly gradual, although some sharp contacts are observed locally. Figure F51 illustrates an apparent cyclic nature of some resistive and conductive intervals on the FMS images from 125 to 135 mbsf. The cyclic pattern consists of $\sim 0.4-1 \mathrm{~m}$ thick resistive intervals (light color in the FMS image in Fig. F51), generally correlating with higher values in the gamma ray, bulk density, and resistivity logs. We interpret this as reflecting relatively clay rich intervals. These resistive intervals alternate with conductive intervals (dark color in the FMS image), generally correlating to laminated (diatomite or carbonate rich) intervals characterized by lower values in the gamma ray, bulk density, and resistivity logs. These very preliminary observations, however, need to be further examined by postexpedition shore-based research.

The resistive-conductive cycles described above are only slightly visible across certain intervals characterized by irregular enlarged borehole diameter, especially from $\sim 168$ to 190 mbsf.

In the lower part of the borehole, deeper than 244 mbsf (logging Unit LII), FMS images are characterized by highly resistive layers (in white in the FMS images) alternating with lower resistivity layers (Fig. F50). Core recovery across logging Unit LII is low. A first attempt of core-log integration suggests that some of the high-resistivity layers correlate to tephra and tuff layers in Sections 346-U1430B-32X-1 and 32X-CC. These preliminary observations, however, need to be further examined by postexpedition shore-based research. It should be possible to assess the lithologic successions within the core gaps by 
combining the density, resistivity, and gamma ray logs with the FMS images.

\section{In situ temperature and heat flow}

APCT-3 downhole temperature measurements were performed in Hole U1430A at five depths including the mudline. In situ temperatures range from $3.36^{\circ} \mathrm{C}$ at $32.1 \mathrm{~m}$ CSF-A to $12.11^{\circ} \mathrm{C}$ at $117.6 \mathrm{~m}$ CSF-A (Table T17). The temperatures increase linearly with depth deeper than $32.1 \mathrm{~m}$ CSF-A. The trend line of the in situ temperature measurements intersects the seafloor at $0.1^{\circ} \mathrm{C}$ (Fig. F52A). This is slightly lower than the average of the lowest mudline temperature in the four APCT-3 measurements $\left(0.58^{\circ} \mathrm{C}\right)$. A linear fit of temperature versus depth gives a geothermal gradient of $103^{\circ} \mathrm{C} / \mathrm{km}$. A heat flow of $93 \mathrm{~mW} / \mathrm{m}^{2}$ was obtained from the slope of the linear fit between in situ temperature and the calculated in situ thermal resistance (Fig. F52) (Pribnow et al., 2000).

\section{Stratigraphic correlation and sedimentation rates}

During drilling operations, real-time tracking of the relative positions of core gaps in the three holes at Site U1430 was accomplished using magnetic susceptibility and GRA data from the WRMSL and Special Task Multisensor Logger. Data were collected at a resolution of $5 \mathrm{~cm}$, which was sufficient to keep up with core recovery rates. At this site, the sea state was relatively calm and gas expansion was minimal. Detailed (centimeter scale) compositing and splicing (see "Stratigraphic correlation and sedimentation rates" in the "Methods" chapter [Tada et al., 2015b]) are based on the high-resolution RGB color data (blue) recovered from the Section Half Imaging Logger at $0.5 \mathrm{~cm}$ resolution. For detailed discussion of these data sets, see "Physical properties" in the "Methods" chapter (Tada et al., 2015b).

Three holes were drilled at this site: two holes (U1430A and U1430B) to $275 \mathrm{~m} \mathrm{CSF}-\mathrm{A}$ and a third hole (U1430C) to $250 \mathrm{~m}$ CSF-A. After all cores were composited (Table T18), a splice (Table T19) was constructed primarily using Hole U1430B with shorter sections from Hole U1430A utilized to span the Hole U1430B core gaps. The splice spans the entire length of the overlapped intervals among the three holes from the mudline to Section 346U1430A-28H-3, $76 \mathrm{~cm}$ (243.9 m CSF-A; $259.1 \mathrm{~m}$ CCSF-D, as defined in the "Methods" chapter [Tada et al., 2015b]) (Fig. F53). Based on the difference between the CCSF-D and CSF-A depths at the bottom of the spliced interval, expansion at this site was $\sim 6 \%$.
A CCSF-C scale (as defined in "Stratigraphic correlation and sedimentation rates" in the "Methods" chapter [Tada et al., 2015b]) was created for cores from Hole U1430C by mapping them into the splice using the core-log integration functionality in Correlator. Cores $346-\mathrm{U} 1430 \mathrm{C}-4 \mathrm{H}$ and $5 \mathrm{H}$ are not well correlated to cores at equivalent depths in the other two holes because of the presence of slump structures (see "Lithostratigraphy"). Construction of the CCSF-C scale is based on correlation of structure in the RGB (blue) data (Table T20).

\section{Age model and sedimentation rates}

A preliminary age model was established on the basis of all available biostratigraphic and paleomagnetic age control points (Fig. F54A; Table T21). The B/M boundary is taken as an age-depth inflection point at $34.45 \mathrm{~m}$ CCSF-A (0.781 Ma) because the average slope in the interval between 50 and $80 \mathrm{~m} \mathrm{CCSF-A} \mathrm{is}$ well constrained by biostratigraphic events and appears to be smaller than the slope between the seafloor and the $\mathrm{B} / \mathrm{M}$ boundary.

Because the LO of L. redondoensis (5.06 Ma), the FOs of L. pylomaticus (5.30 Ma) and Thalassiosira oestrupii (5.56 Ma), and the LO of C. nakasekoi (7.40 Ma) all occurred at the same horizon (Section 346-U1430A9H-CC; $83.45 \mathrm{~m}$ CCSF-A), we infer a hiatus lasting at least from 7.40 to $5.06 \mathrm{Ma}$ at this horizon. The line connecting the $\mathrm{B} / \mathrm{M}$ boundary and the depth-age of the LO of L redondoensis defines a second segment of depth-age relationship, which defines the ages of the Subunit IA/IB and IB/IIA boundaries. In order to minimize the number of inflection points in the depth-age relationship below the inferred hiatus, we connected the LO of C. nakasekoi and the LO of $L$. renzae. The depth-age line connecting these two points defines the ages of the Subunit IIB/IIIA and IIIA/IIIB boundaries. The depth-age line that defined the sedimentation rates of Subunit IIIA was also well constrained between the LOs of D. katayamae, Cyrtocapsella japonica, and D. hustedtii and the FOs of $C$. nakasekoi and Lychnocanoma magnacornuta. A depthage line connecting the LO of $L$. renzae and the LO of Dendrospyris sakii defines the sedimentation rates of Subunit IIIB and Unit IV. The resulting ages of the lithologic boundaries are provided in Table T21.

Sedimentation rates at Site U1430 range from 3.3 to $44 \mathrm{~m} / \mathrm{m}$.y. with an inferred hiatus at $83.45 \mathrm{~m}$ CCSF-A. Sedimentation rates are relatively high in Subunits IA and IIIA, moderate in Subunits IB and IIA, and low in Subunit IIIB and Unit IV (Fig. F54B). Higher sedimentation rates tend to be associated with higher GRA density, which suggests higher detrital flux. Increased detrital flux results in increased sedimentation rates and GRA density because of reduced 
dilution of low-density biogenic material. Although clear lithologic evidence of a hiatus was not found in Cores $346-\mathrm{U} 1430 \mathrm{~A}-9 \mathrm{H}$ and $10 \mathrm{H}$, low sedimentation rates are suggested by the glauconite-bearing condensed section found in interval 346-U1430A-9H-4, $70-150 \mathrm{~cm}$, and in the corresponding intervals 346U1430B-9H-1, 105-147 cm, and 346-U1430C-9H-2, $120 \mathrm{~cm}$, to $9 \mathrm{H}-2,25 \mathrm{~cm}$ (see "Lithostratigraphy"). Glauconite sand-rich intervals of Unit IV also indicate low sedimentation rates at $3.3 \mathrm{~m} / \mathrm{m}$.y.

\section{References}

Baker, P.A., and Kastner, M., 1981. Constraints on the formation of sedimentary dolomite. Science,

213(4504):214-216. doi:10.1126/sci-

ence.213.4504.214

Baldauf, J.G., and Barron, J.A., 1980. Actinocyclus ingens var. nodus: a new, stratigraphically useful diatom of the circum-North Pacific. Micropaleontology, 26(1):103-110. doi:10.2307/1485279

Blum, P., 1997. Physical properties handbook: a guide to the shipboard measurement of physical properties of deep-sea cores. ODP Tech. Note, 26. doi:10.2973/ odp.tn.26.1997

Froelich, P.N., Klinkhammer, G.P., Bender, M.L., Luedtke, N.A., Heath, G.R., Cullen, D., Dauphin, P., Hammond, D., Hartman, B., and Maynard, V., 1979. Early oxidation of organic matter in pelagic sediments of the eastern equatorial Atlantic: suboxic diagenesis. Geochim. Cosmochim. Acta, 43(7):1075-1090. doi:10.1016/00167037(79)90095-4

Gardner, J.V., Nelson, C.S., and Baker, P.A., 1986. Distribution and character of pale green laminae in sediment from Lord Howe Rise: a probable late Neogene and Quaternary tephrostratigraphic record. In Kennett, J.P., von der Borch, C.C., et al., Init. Repts. DSDP, 90: Washington, DC (U.S. Govt. Printing Office), 1145-1159. doi:10.2973/dsdp.proc.90.125.1986

Gooday, A.J., 1993. Deep-sea benthic foraminiferal species which exploit phytodetritus: characteristic features and controls on distribution. Mar. Micropaleontol., 22(3):187-205. doi:10.1016/0377-8398(93)90043-W

Hase, H., Yoon, J.-H., and Koterayama, W., 1999. The current structure of the Tsushima Warm Current along the Japan coast. J. Oceanogr., 55(2):217-235. doi:10.1023/ A:1007894030095

Ingle, J.C., Jr., Suyehiro, K., von Breymann, M.T., et al., 1990. Proc. ODP, Init. Repts., 128: College Station, TX (Ocean Drilling Program). doi:10.2973/ odp.proc.ir.128.1990

Irino, T., and Tada, R., 2000. Quantification of aeolian dust (Kosa) contribution to the Japan Sea sediments and its variation during the last $200 \mathrm{ky}$. Geochem. J., 34(1):5993. doi:10.2343/geochemj.34.59

Isobe, A., Ando, M., Watanabe, T., Senjyu, T., Sugihara, S., and Manda, A., 2002. Freshwater and temperature transports through the Tsushima-Korea Straits. J. Geo- phys. Res.: Oceans, 107(C7):3065. doi:10.1029/ 2000JC000702

Isoda, Y., 2011. Climate change and physical process associated with the Tsushima Warm Current. Mem. Fac. Fish. Sci., Hokkaido Univ., 53(2):2-12. http://hdl.handle.net/ 2115/47547

Jorissen, F.J., 1999. Benthic foraminiferal microhabitats below the sediment-water interface. In Sen Gupta, B.K. (Ed.), Modern Foraminifera: Dordrecht (Kluwer), 161179. doi:10.1007/0-306-48104-9_10

Jorissen, F.J., de Stigter, H.C., and Widmark, J.G.V., 1995. A conceptual model explaining benthic foraminiferal microhabitats. Mar. Micropaleontol., 26(1-4):3-15. doi:10.1016/0377-8398(95)00047-X

Jorissen, F.J., Fontanier, C., and Thomas, E., 2007. Paleoceanographical proxies based on deep-sea benthic foraminiferal assemblage characteristics. In Hillaire-Marcel, C. and De Vernal, A. (Eds.), Proxies in Late Cenozoic Paleoceanography. Dev. Mar. Geol., 263-325. doi:10.1016/ S1572-5480(07)01012-3

Kastner, M., Keene, J.B., and Gieskes, J.M., 1977. Diagenesis of siliceous oozes, I. Chemical controls on the rate of opal-A to opal-CT transformation-an experimental study. Geochim. Cosmochim. Acta, 41(8):1041-1051. doi:10.1016/0016-7037(77)90099-0

Kucera, M., and Kennett, J.P., 2000. Biochronology and evolutionary implications of late Neogene California margin planktonic foraminiferal events. Mar. Micropaleontol., 40(1-2):67-81. doi:10.1016/

S0377-8398(00)00029-3

Lee, K.E., Bahk, J.J., and Choi, J., 2008. Alkenone temperature estimates for the East Sea during the last 190,000 years. Org. Geochem., 39(6):741-753. doi:10.1016/j.orggeochem.2008.02.003

Maiya, S., 1978. Late Cenozoic planktonic foraminiferal biostratigraphy of the oil-field region of northeast Japan. In Cenozoic Geology of Japan: Osaka, 35-60. (in Japanese, with abstract in English)

Masuzawa, T., and Kitano, Y., 1983. Interstitial water chemistry in deep-sea sediments from the Japan Sea. J. Oceanogr. Soc. Jpn., 39(4):171-184. doi:10.1007/ BF02070261

Murray, R.W., Brumsack, H.J., von Breymann, M.T., Sturz, A.A., Dunbar, R.B., and Gieskes, J.M., 1992. Diagenetic reactions in deeply buried sediments of the Japan Sea: a synthesis of interstitial-water chemistry results from Legs 127 and 128. In Tamaki, K., Suyehiro, K., Allan, J., McWilliams, M., et al., Proc. ODP, Sci. Results, 127/128 (Pt. 2): College Station, TX (Ocean Drilling Program), 1261-1274. doi:10.2973/odp.proc.sr.1271282.177.1992

Pribnow, D., Kinoshita, M., and Stein, C., 2000. Thermal Data Collection and Heat Flow Recalculations for Ocean Drilling Program Legs 101-180: Hanover, Germany (Inst. Joint Geosci. Res., Inst. Geowiss. Gemeinschaftsauf. [GGA]). http://www-odp.tamu.edu/publications/ heatflow/ODPReprt.pdf

Sudo, H., 1986. A note on the Japan Sea Proper Water. Prog. Oceanogr., 17(3-4):313-336. doi:10.1016/00796611(86)90052-2 
Sun, Y., and An, Z., 2005. Late Pliocene-Pleistocene changes in mass accumulation rates of eolian deposits on the central Chinese Loess Plateau. J. Geophys. Res.: Atmos., 110(D23):D23101. doi:10.1029/2005JD006064

Tada, R., 1994. Paleoceanographic evolution of the Japan Sea. Palaeogeogr., Palaeoclimatol., Palaeoecol., 108(34):487-508. doi:10.1016/0031-0182(94)90248-8

Tada, R., Murray, R.W., Alvarez Zarikian, C.A., Anderson, W.T., Jr., Bassetti, M.-A., Brace, B.J., Clemens, S.C., da Costa Gurgel, M.H., Dickens, G.R., Dunlea, A.G., Gallagher, S.J., Giosan, L., Henderson, A.C.G., Holbourn, A.E., Ikehara, K., Irino, T., Itaki, T., Karasuda, A., Kinsley, C.W., Kubota, Y., Lee, G.S., Lee, K.E., Lofi, J., Lopes, C.I.C.D., Peterson, L.C., Saavedra-Pellitero, M., Sagawa, T., Singh, R.K., Sugisaki, S., Toucanne, S., Wan, S., Xuan, C., Zheng, H., and Ziegler, M., 2015a. Expedition 346 summary. In Tada, R., Murray, R.W., Alvarez Zarikian, C.A., and the Expedition 346 Scientists, Proc. IODP, 346: College Station, TX (Integrated Ocean Drilling Program). doi:10.2204/iodp.proc.346.101.2015

Tada, R., Murray, R.W., Alvarez Zarikian, C.A., Anderson, W.T., Jr., Bassetti, M.-A., Brace, B.J., Clemens, S.C., da Costa Gurgel, M.H., Dickens, G.R., Dunlea, A.G., Gallagher, S.J., Giosan, L., Henderson, A.C.G., Holbourn, A.E., Ikehara, K., Irino, T., Itaki, T., Karasuda, A., Kinsley, C.W., Kubota, Y., Lee, G.S., Lee, K.E., Lofi, J., Lopes, C.I.C.D., Peterson, L.C., Saavedra-Pellitero, M., Sagawa, T., Singh, R.K., Sugisaki, S., Toucanne, S., Wan, S., Xuan, C., Zheng, H., and Ziegler, M., 2015b. Methods. In Tada, R., Murray, R.W., Alvarez Zarikian, C.A., and the Expedition 346 Scientists, Proc. IODP, 346: College Station, TX (Integrated Ocean Drilling Program). doi:10.2204/ iodp.proc.346.102.2015

Tada, R., Murray, R.W., Alvarez Zarikian, C.A., Anderson, W.T., Jr., Bassetti, M.-A., Brace, B.J., Clemens, S.C., da Costa Gurgel, M.H., Dickens, G.R., Dunlea, A.G., Gallagher, S.J., Giosan, L., Henderson, A.C.G., Holbourn, A.E., Ikehara, K., Irino, T., Itaki, T., Karasuda, A., Kinsley,
C.W., Kubota, Y., Lee, G.S., Lee, K.E., Lofi, J., Lopes, C.I.C.D., Peterson, L.C., Saavedra-Pellitero, M., Sagawa, T., Singh, R.K., Sugisaki, S., Toucanne, S., Wan, S., Xuan, C., Zheng, H., and Ziegler, M., 2015c. Site U1422. In Tada, R., Murray, R.W., Alvarez Zarikian, C.A., and the Expedition 346 Scientists, Proc. IODP, 346: College Station, TX (Integrated Ocean Drilling Program). doi:10.2204/iodp.proc.346.103.2015

Tada, R., Murray, R.W., Alvarez Zarikian, C.A., Anderson, W.T., Jr., Bassetti, M.-A., Brace, B.J., Clemens, S.C., da Costa Gurgel, M.H., Dickens, G.R., Dunlea, A.G., Gallagher, S.J., Giosan, L., Henderson, A.C.G., Holbourn, A.E., Ikehara, K., Irino, T., Itaki, T., Karasuda, A., Kinsley, C.W., Kubota, Y., Lee, G.S., Lee, K.E., Lofi, J., Lopes, C.I.C.D., Peterson, L.C., Saavedra-Pellitero, M., Sagawa, T., Singh, R.K., Sugisaki, S., Toucanne, S., Wan, S., Xuan, C., Zheng, H., and Ziegler, M., 2015d. Site U1423. In Tada, R., Murray, R.W., Alvarez Zarikian, C.A., and the Expedition 346 Scientists, Proc. IODP, 346: College Station, TX (Integrated Ocean Drilling Program). doi:10.2204/iodp.proc.346.104.2015

Tamaki, K., Pisciotto, K., Allan, J., et al., 1990. Proc. ODP, Init. Repts., 127: College Station, TX (Ocean Drilling Program). doi:10.2973/odp.proc.ir.127.1990

Xuan, C., and Channell, J.E.T., 2009. UPmag: MATLAB software for viewing and processing $U$ channel or other pass-through paleomagnetic data. Geochem., Geophys., Geosyst., 10(10):Q10Y07. doi:10.1029/2009GC002584

Yanagisawa, Y., and Akiba, F., 1998. Refined Neogene diatom biostratigraphy for the northwest Pacific around Japan, with an introduction of code numbers for selected diatom biohorizons. Chishitsugaku Zasshi, 104(6):395-414. doi:10.5575/geosoc.104.395

Publication: 28 March 2015 MS 346-110 
Figure F1. Bathymetric map of Expedition 346 sites (red circles). Sites previously drilled by the Deep Sea Drilling Project (DSDP) and Ocean Drilling Program (ODP) (white circles) are also shown. Also illustrated are surface current systems.

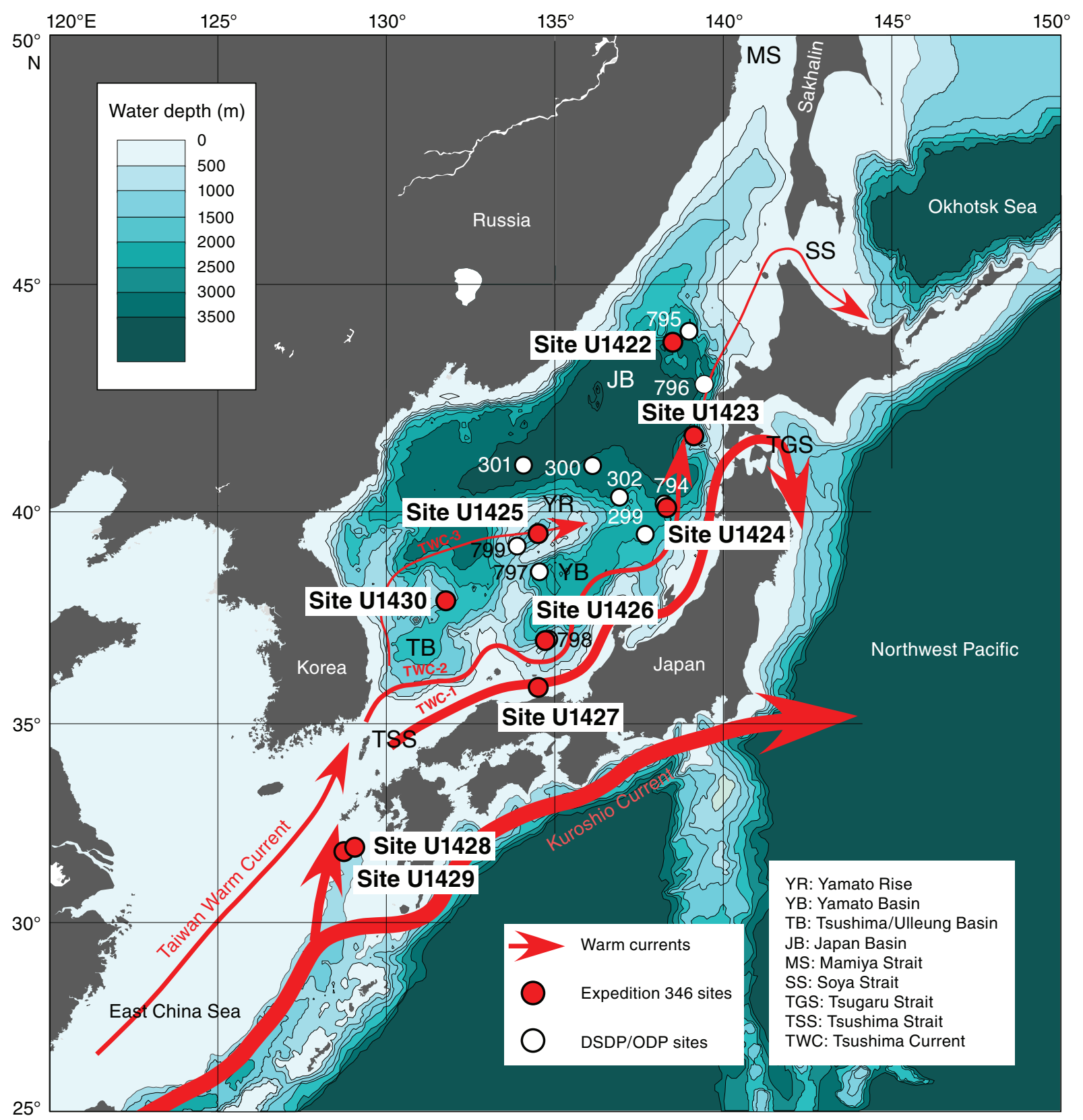


Figure F2. Lithologic summary, Hole U1430A. GRA = gamma ray attenuation.

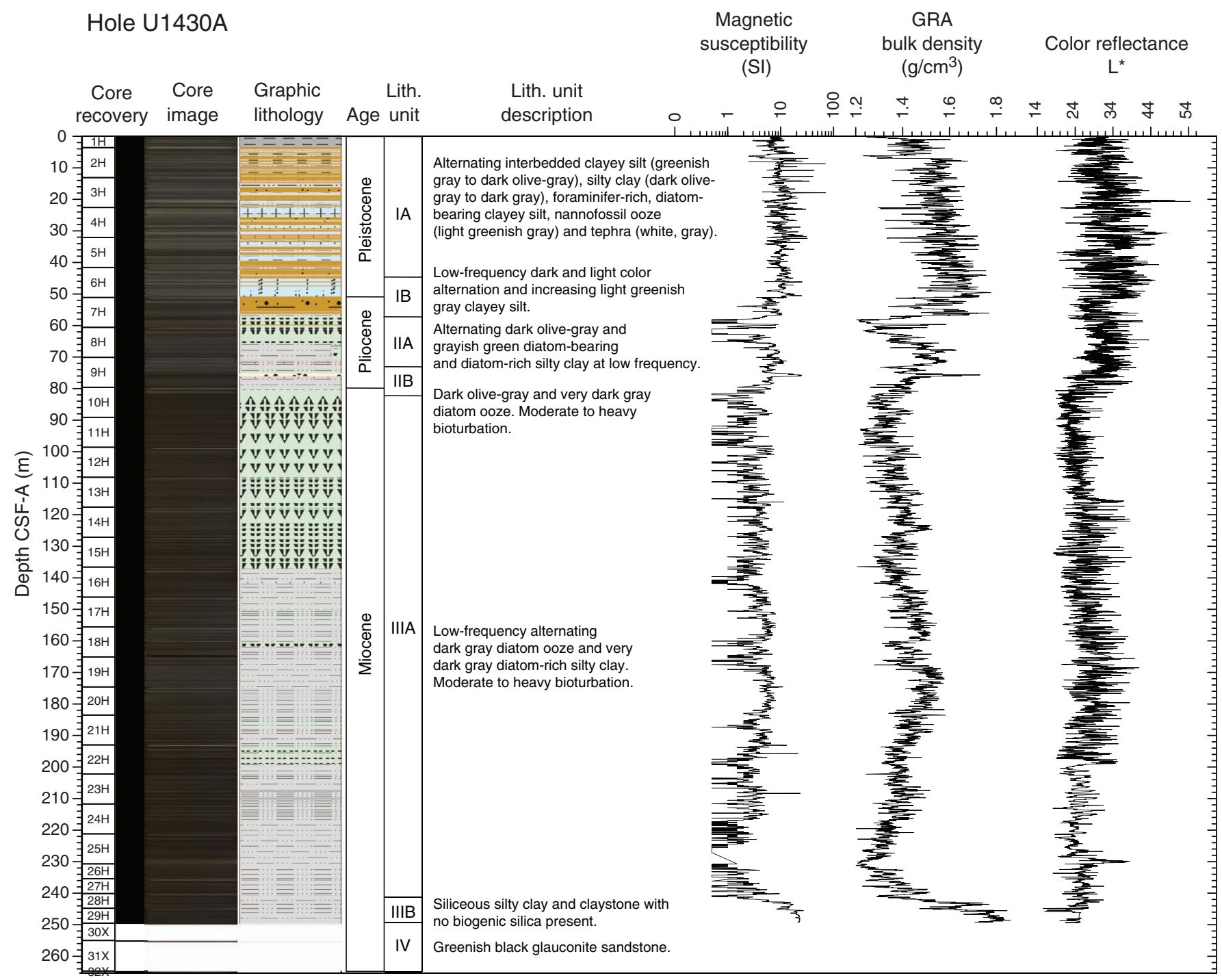


Figure F3. Lithologic summary, Hole U1430B. GRA = gamma ray attenuation.

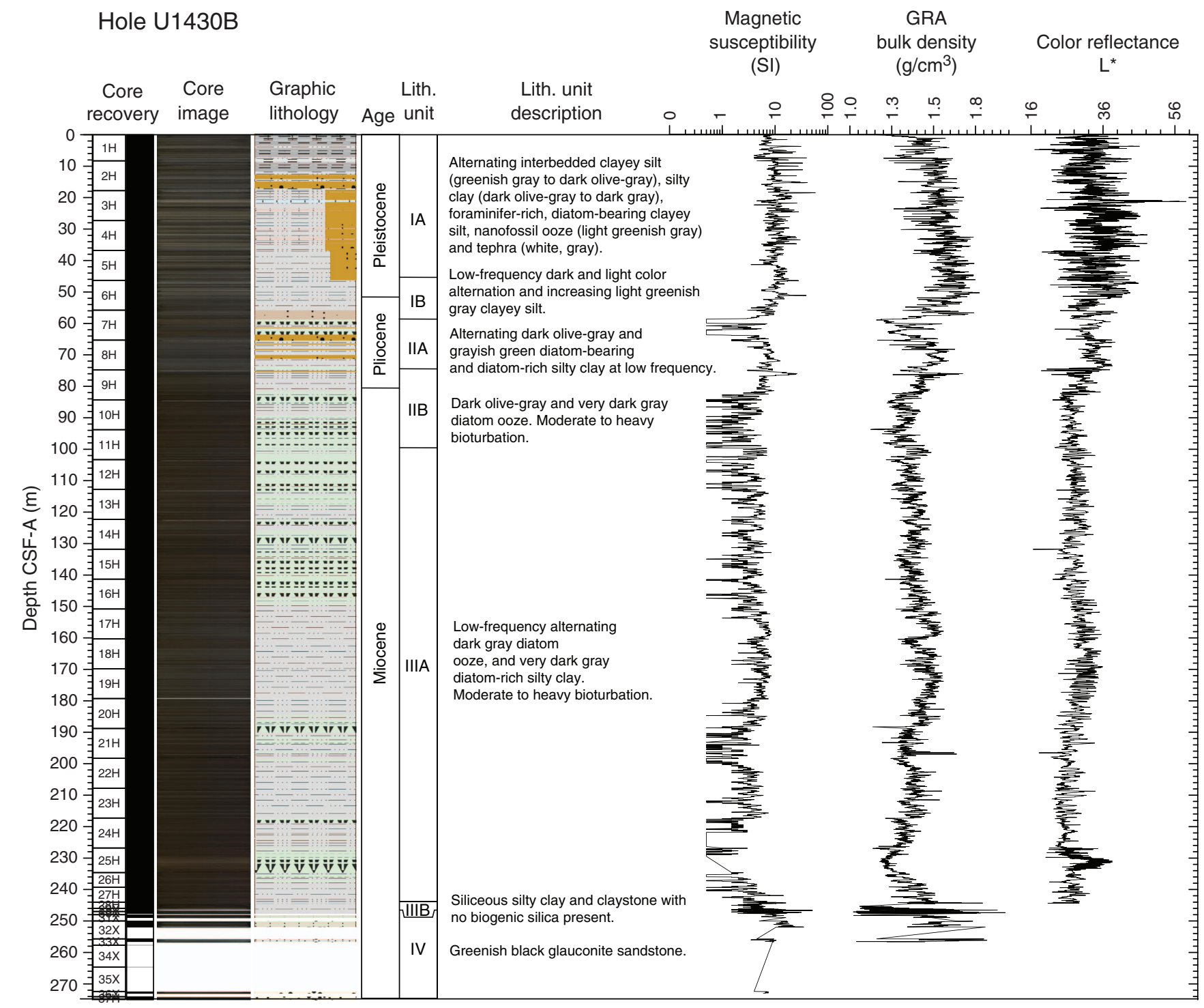


Figure F4. Lithologic summary, Hole U1430C. GRA = gamma ray attenuation.

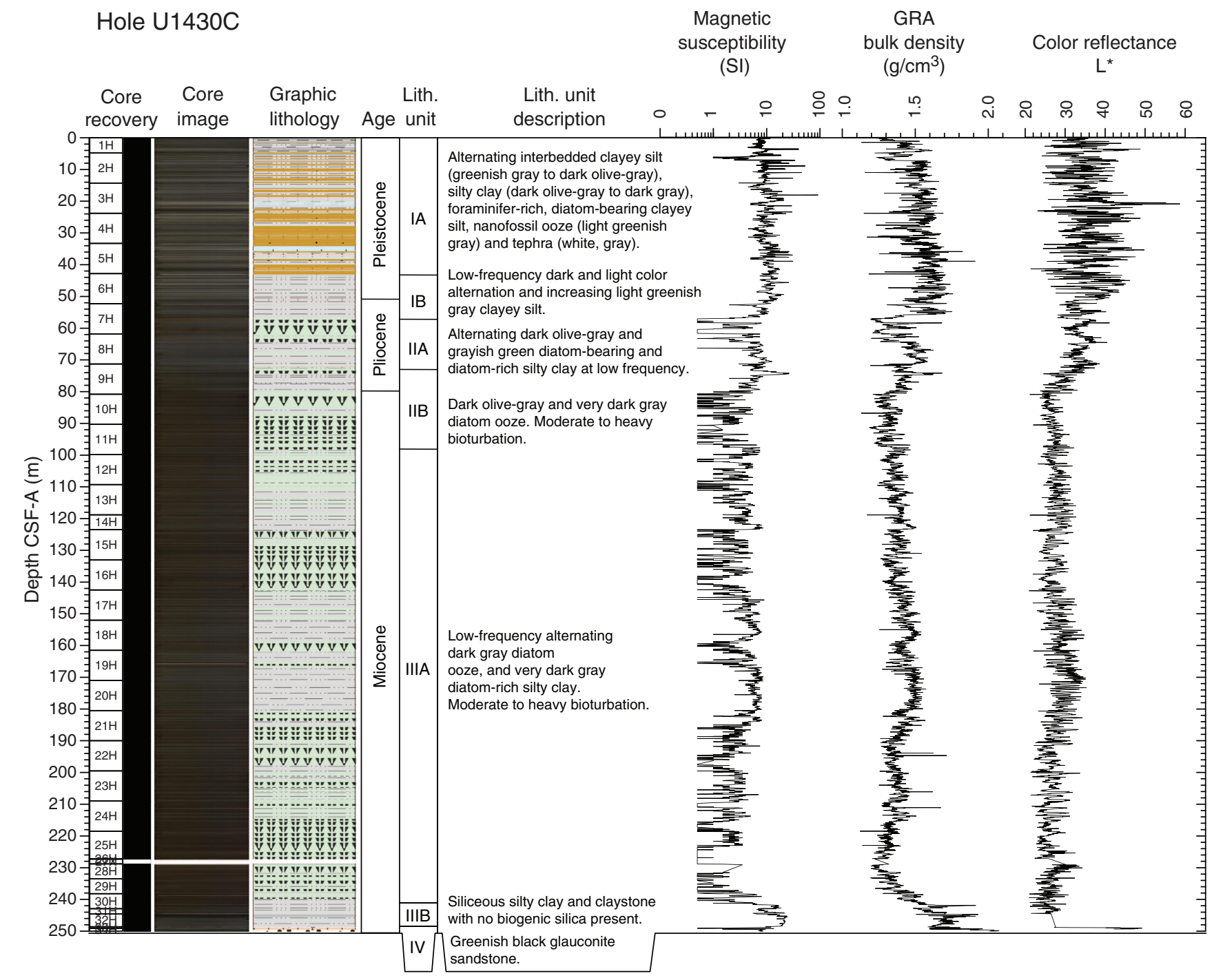


Figure F5. Distribution of tephra layers and total thickness of tephra in each core, Hole U1430A.

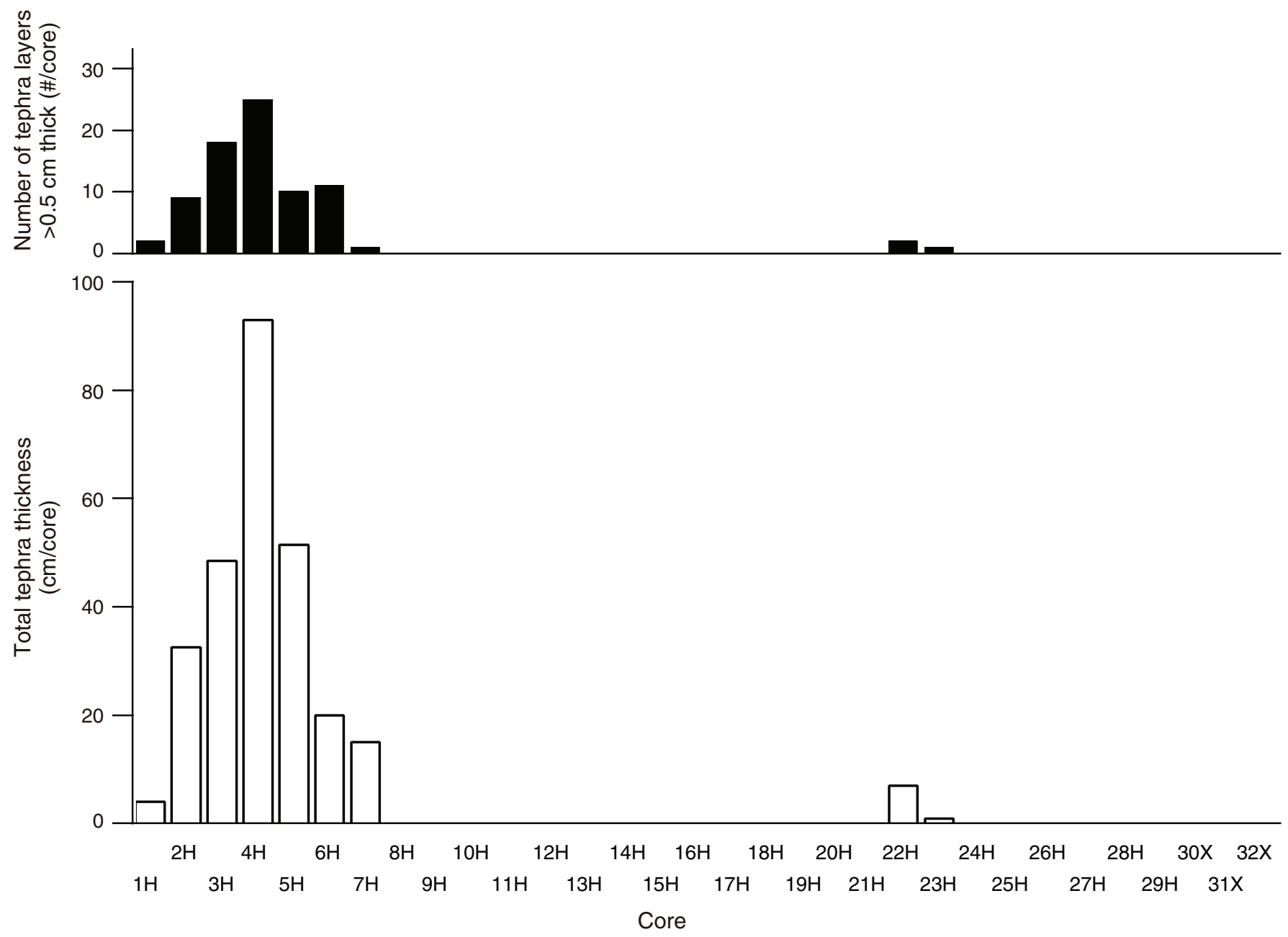


Figure F6. Hole-to-hole correlation of lithologic units, Site U1430.

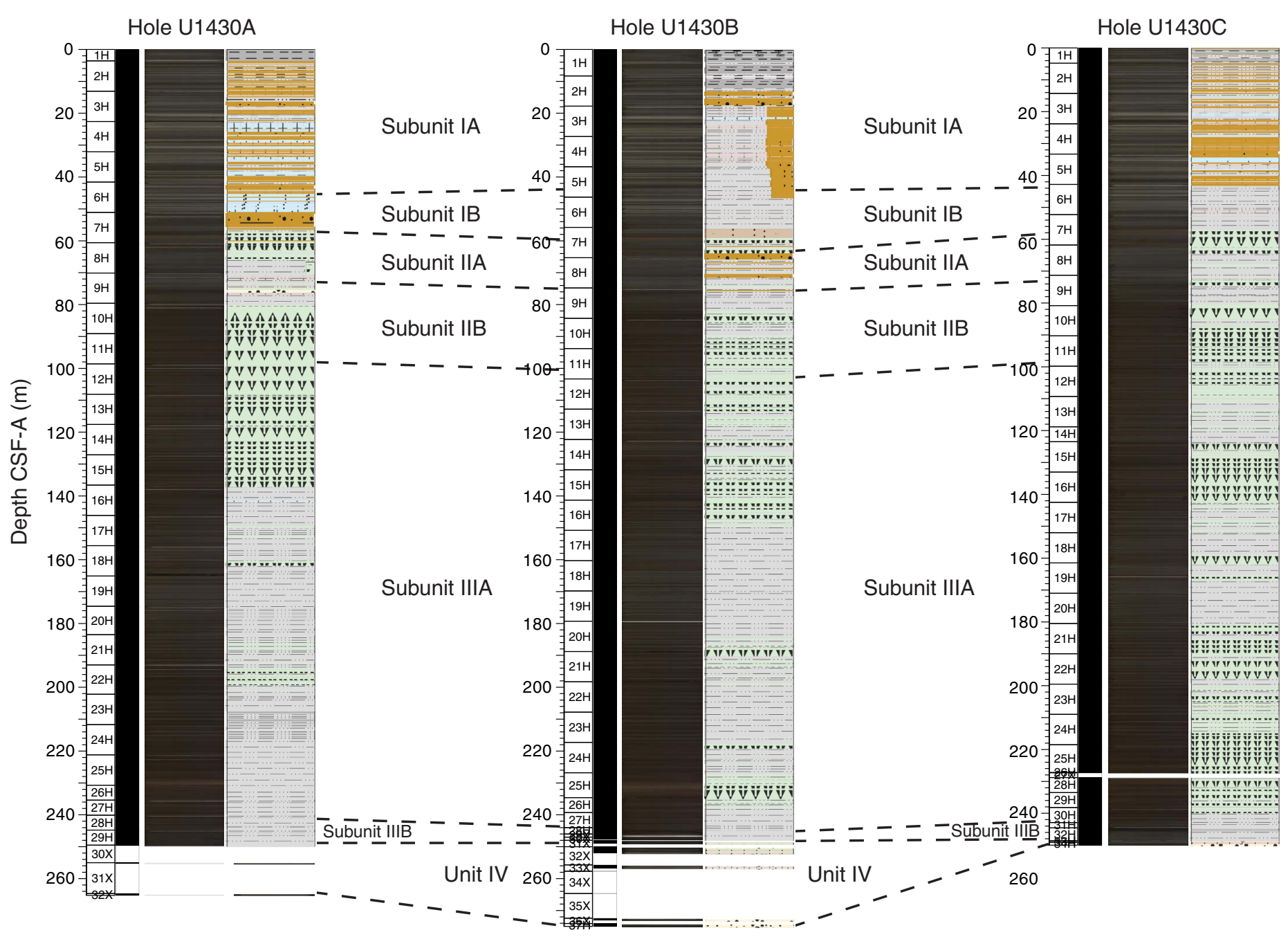


Figure F7. Variation of bulk sediment sample XRD peak intensities of identified minerals with depth, Site U1430.

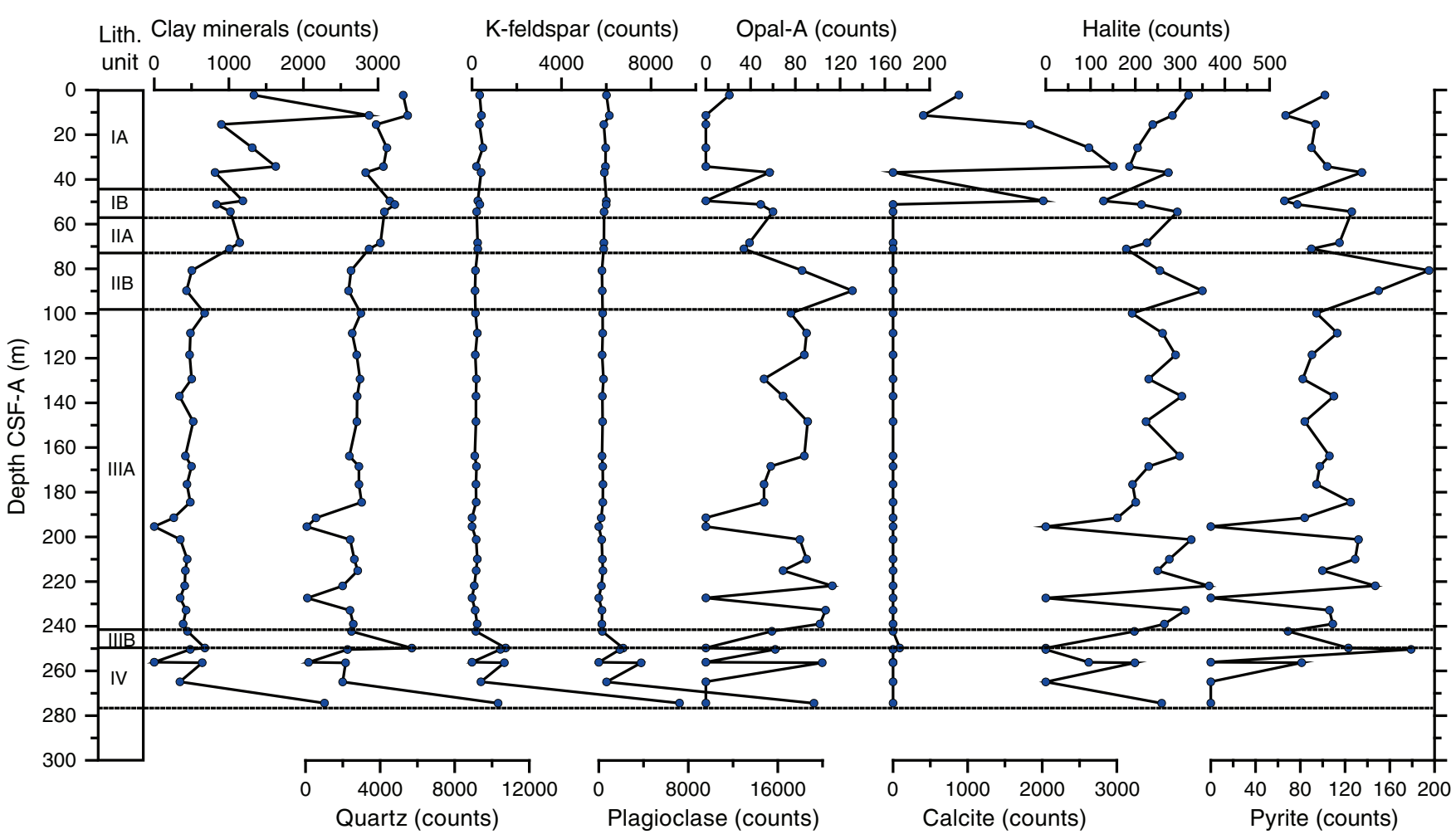


Figure F8. Photographs showing sediment representative of Subunit IA, Hole U1430A. Note that core images have been enhanced using a color contrast to highlight sedimentary structures.

\section{Hole U1430A \\ Subunit IA}

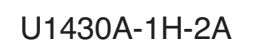

U1430A-2H-3A 6.60-8.10 m CSF-A

U1430A-3H-6A 20.60-22.10 m CSF-A

U1430A-4H-2A 24.10-25.60 m CSF-A

U1430A-5H-2A 33.60-35.10 m CSF-A

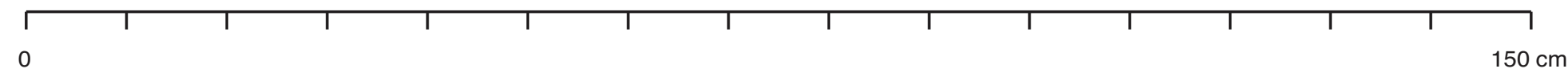


Figure F9. Comparison of laminations and color banding observed in Subunit IA across marginal basin drilled during Expedition 346. Sediment from Holes U1426C, U1423B, U1424A, U1425B, and U1430A are represented. Note that core images have been enhanced using a color contrast to highlight sedimentary structures.

\section{Characteristic laminations in Subunit IA at 0.4-0.5 Ma}

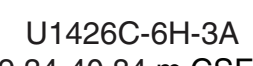

U1425B-3H-1A 18.30-19.80 m CSF-A

U1430A-3H-5A 19.10-20.60 m CSF-A

U1430A-3H-6A 20.60-22.10 m CSF-A 
Figure F10. Photographs representative of Subunit IB, Hole U1430A. Note that core images have been enhanced using a color contrast to highlight sedimentary structures.

Hole U1430A

Subunit IB

U1430A-6H-3A

44.60-46.10 m CSF-A

U1430A-6H-4A

46.10-47.60 m CSF-A

U1430A-6H-5A

47.60-49.10 m CSF-A

U1430A-6H-6A

49.10-50.60 m CSF-A

U1430A-7H-2A

52.60-54.10 m CSF-A

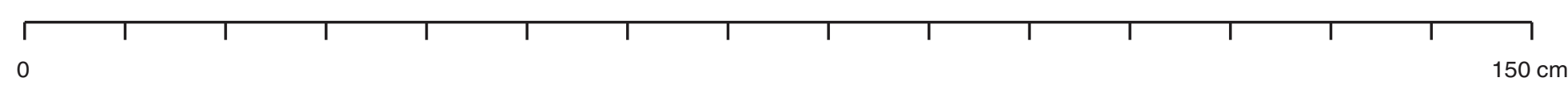


Figure F11. Smear slide images showing glauconite in (A) Sample 346-U1430A-6H-CC, 2 cm, and (B-D) in tephra layer at Sample 346-U1430A$9 \mathrm{H}-4,100 \mathrm{~cm}$. D is under crossed nicols and shows that glauconite has filled the interior space of a diatom but kept the diatom's original texture. E. Photograph of full Section 346-U1430A-6H-CC.

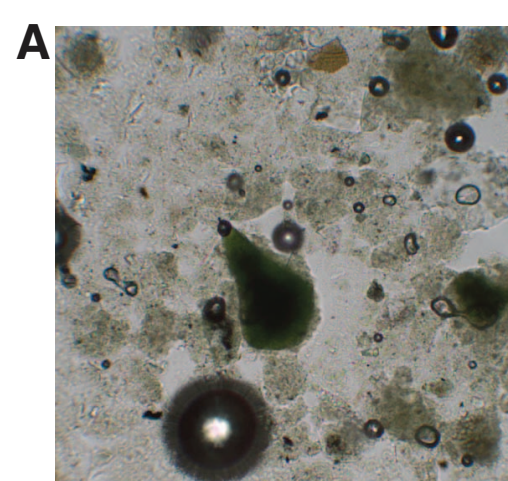

$100 \mu \mathrm{m}$

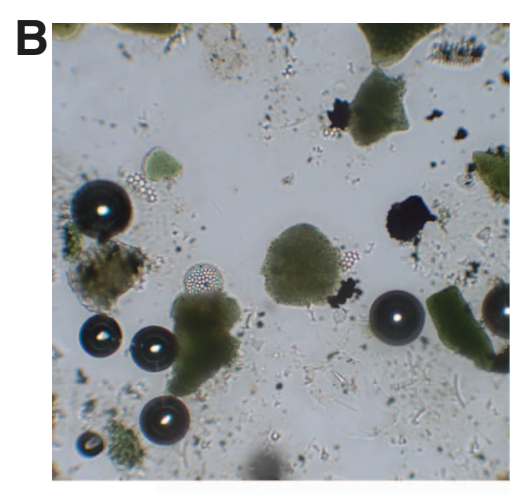

$100 \mu \mathrm{m}$

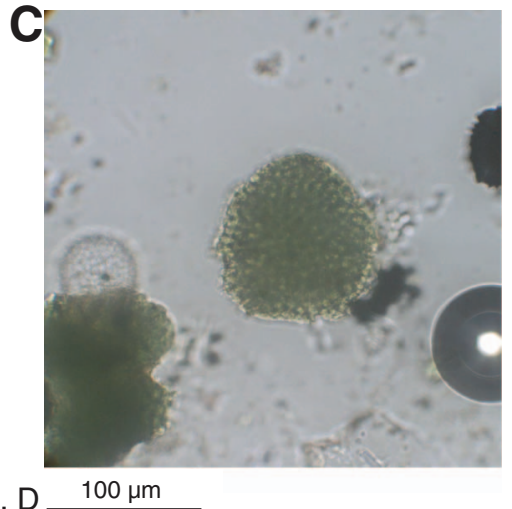

B, C, D $100 \mu \mathrm{m}$

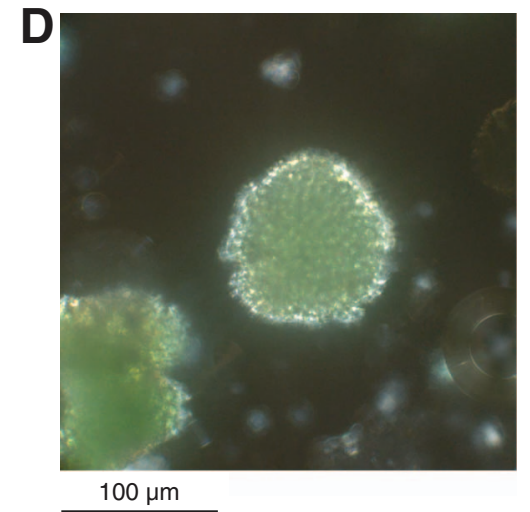

\section{E}

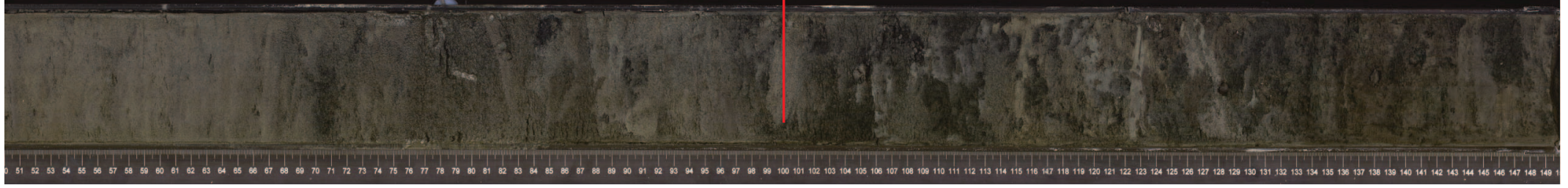


Figure F12. Photographs representative of Subunit IIA, Hole U1430A. Note that core images have been enhanced using a color contrast to highlight sedimentary structures.

Hole U1430A

Subunit IIA

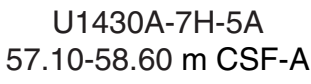

U1430A-7H-6A

58.60-60.10 m CSF-A

U1430A-8H-4A

65.10-66.60 m CSF-A

U1430A-8H-5A 66.60-68.10 m CSF-A

U1430A-8H-6A 68.10-69.60 m CSF-A

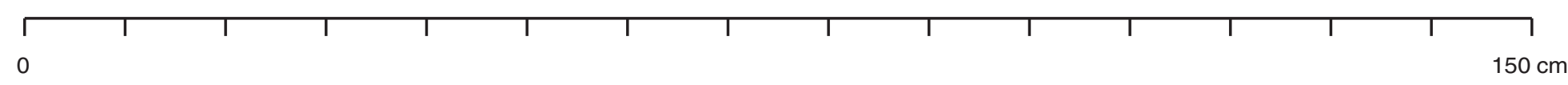


Figure F13. Photographs representative of Subunit IIB, Hole U1430A. Note that core images have been enhanced using a color contrast to highlight sedimentary structures.

Hole U1430A

Subunit IIB

U1430A-9H-4A 74.60-76.10 m CSF-A

U1430A-9H-6A 77.60-79.10 m CSF-A

U1430A-10H-3A 82.60-84.10 m CSF-A

U1430A-10H-5A 85.60-87.10 m CSF-A

U1430A-11H-3A 92.10-93.60 m CSF-A

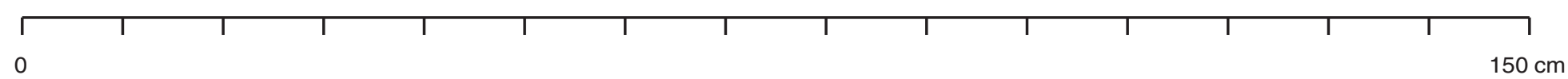


Figure F14. Photographs representative of Subunit IIIA, Hole U1430A. Note that core images have been enhanced using a color contrast to highlight sedimentary structures.

\section{Hole U1430A}

Subunit IIIA

\section{$\mathrm{U} 1430 \mathrm{~A}-13 \mathrm{H}-1 \mathrm{~A}$} 108.10-109.60 m CSF-A

U1430A-13H-5A 114.10-115.60 m CSF-A

U1430A-21H-1A 183.50-185.00 m CSF-A

U130A-21H-6A 191.00-192.02 m CSF-A

\section{U1430A-25H-4A} 225.70-227.20 m CSF-A

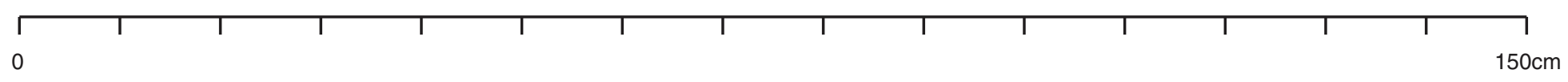


Figure F15. Photographs representative of Subunit IIIB, Hole U1430A. Note that core images have been enhanced using a color contrast to highlight sedimentary structures.

Hole U1430A

Subunit IIIB

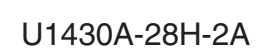

U1430A-28H-3A 243.12-244.32 m CSF-A

U1430A-29H-1A 244.80-246.30 m CSF-A

\section{U1430A-29H-2A} 246.30-247.80 m CSF-A

\section{U1430A-29H-3A} 247.80-249.30 m CSF-A

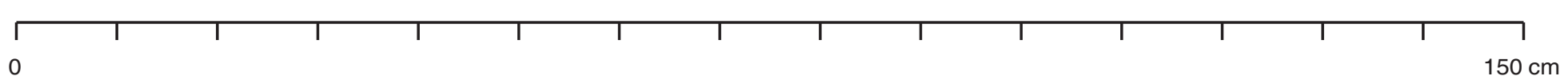


Figure F16. Photographs representative of Unit IV, Hole U1430A. Note that core images have been enhanced using a color contrast to highlight sedimentary structures.

Hole U1430A

Unit IV

U1430A-30X-CC 249.50-249.73 m CSF-A

U1430A-31X-CC 255.00-255.34 m CSF-A

U1430A-32X-CC 264.70-265.25 m CSF-A

U1430B-29X-CC 246.00-246.70 m CSF-A

U1430C-32H-1A 244.60-246.10 m CSF-A

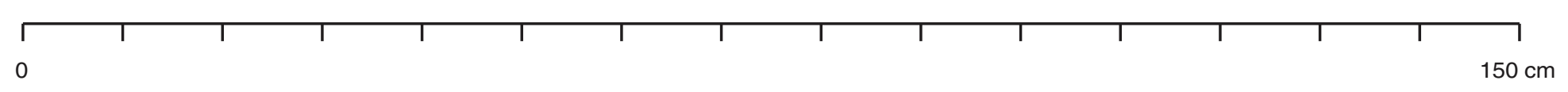


Figure F17. Comparison of XRD diffractogram of two samples (346-U1430A-28H-2A, 64-65 cm, and 30X-CC, 22-23 cm). Note that a typical opal-CT signature appears in the deeper-depth sample.

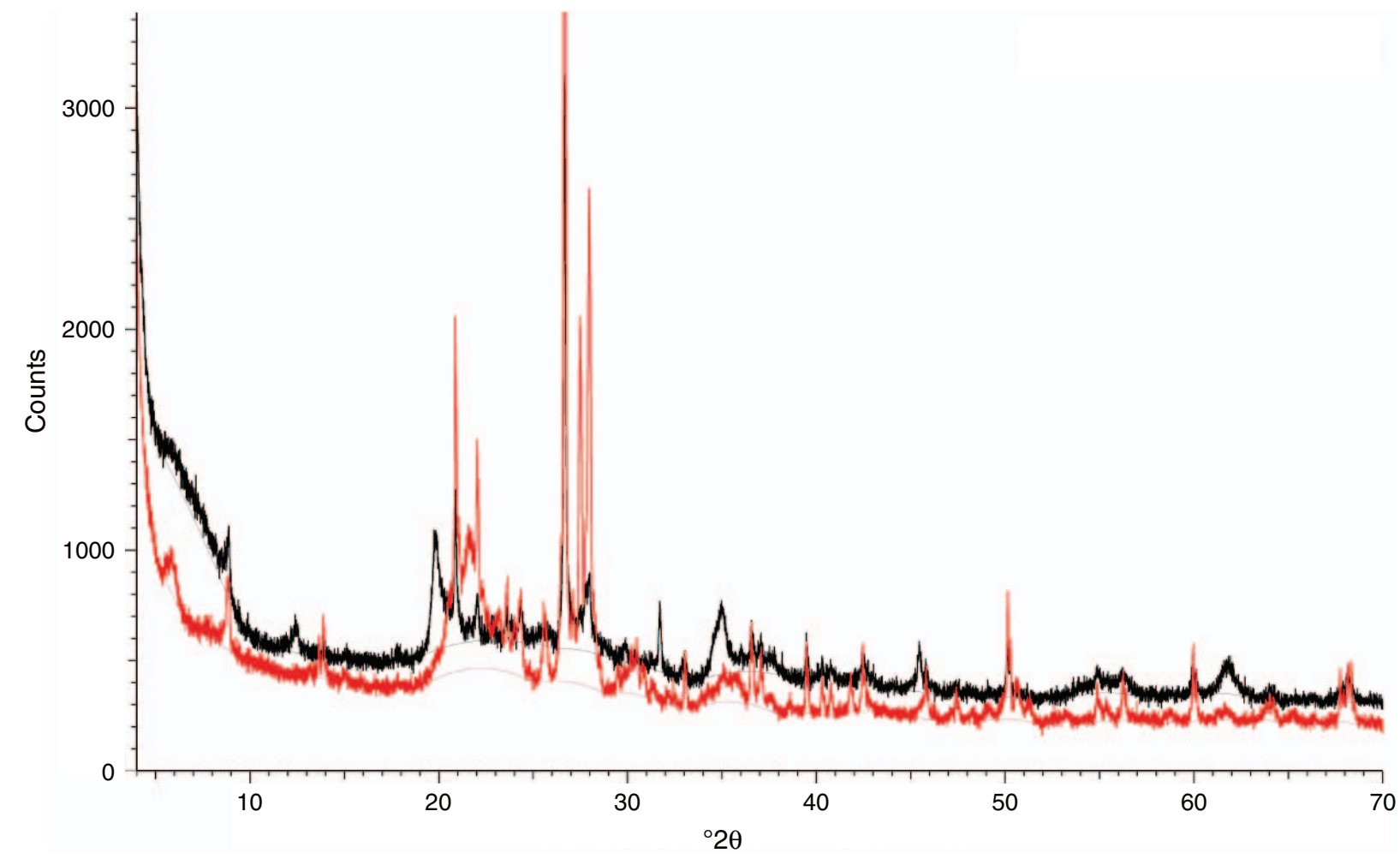

I 346-U1430A-26H-2, 64-65 cm I 346-U1430A-30X-CC, $22-23 \mathrm{~cm}$ 


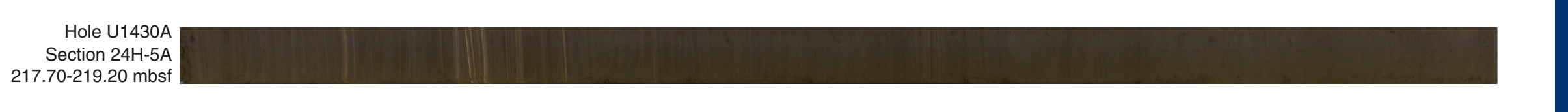

Hole U1430A

Section $25 \mathrm{H}-4 \mathrm{~A}$ 225.70-227.20 mbsf

Hole U1430A Section $25 \mathrm{H}-6 \mathrm{~A}$ 228.70-229.72 mbsf

Hole U1430A Section 25H-7A 229.72-230.44 mbsf

Hole U1430A Section $26 \mathrm{H}-1 \mathrm{~A}$ $230.70-232.20$ mbsf

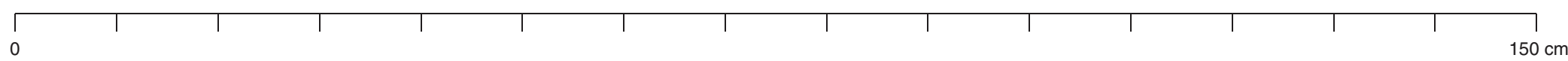


Figure F19. Photograph of core section and XRD diagram corresponding to analysis of a distinctive yellowish sediment layer (Sample 346-U1430A-21H-6A, 43-44 cm).
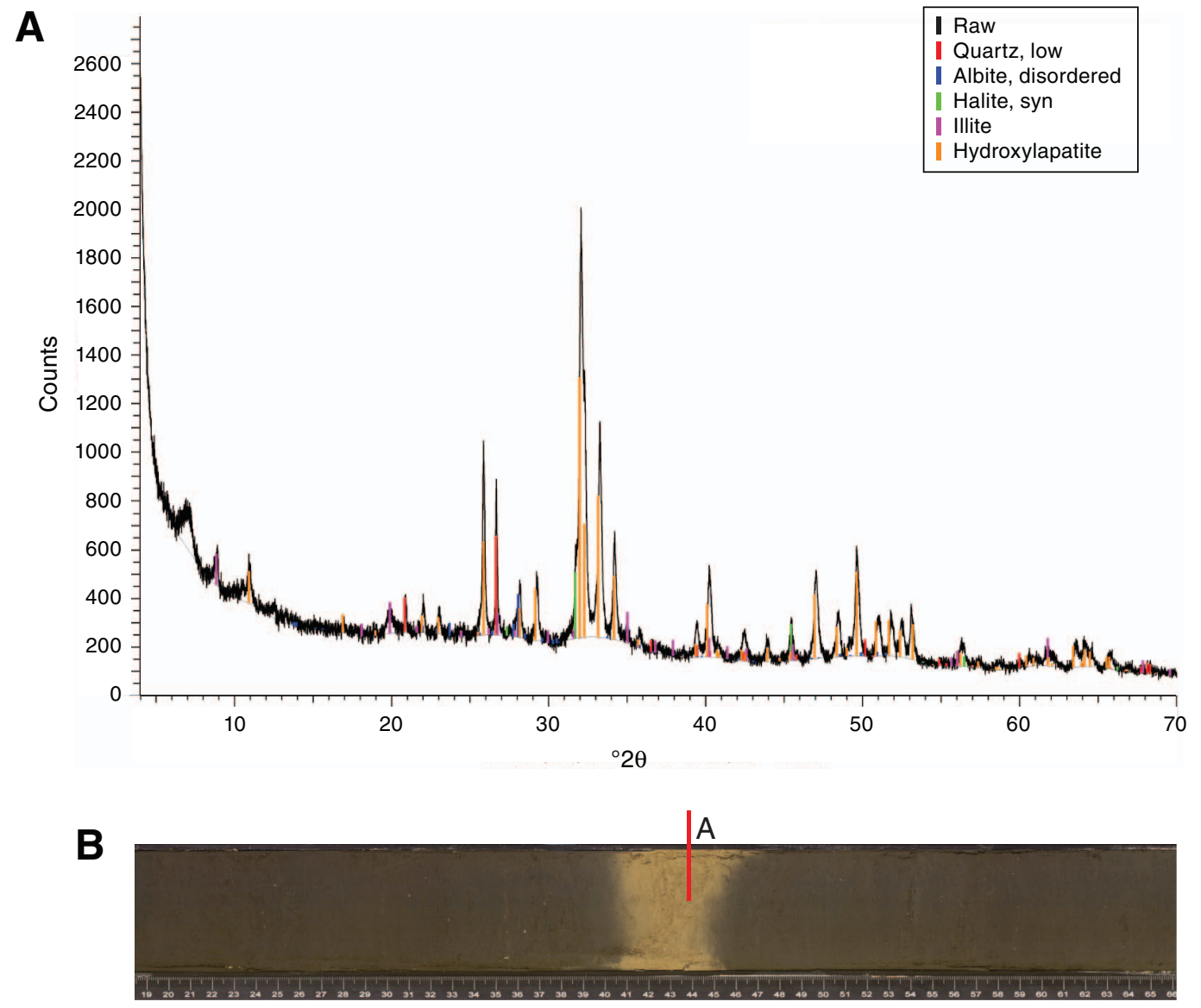
Figure F20. A-D. Smear slide images showing lithologic changes between different color laminations of Subunit IIIA. A. Section 346-U1430A-24H5, $25 \mathrm{~cm}$. B. Section 24H-5, $26.5 \mathrm{~cm}$. C. Section 24H-5, $33 \mathrm{~cm}$. D. Section 24H-5, $35 \mathrm{~cm}$. E. Photograph of full Section 346-U1430A-24H-5.

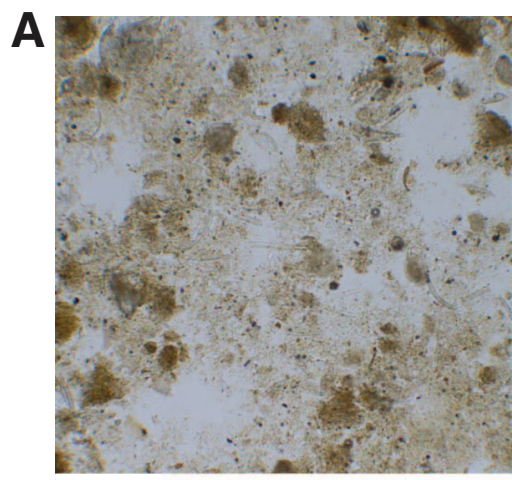

$100 \mu \mathrm{m}$
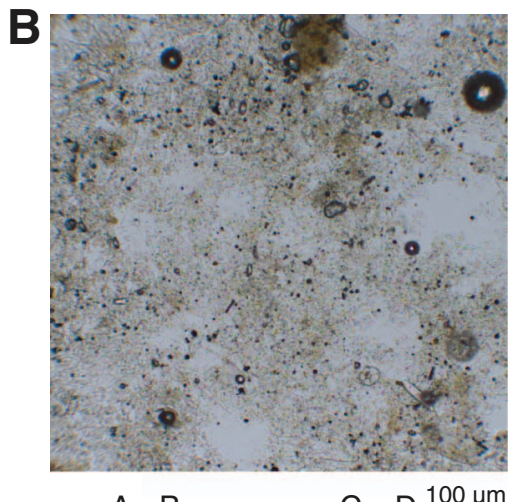

A B

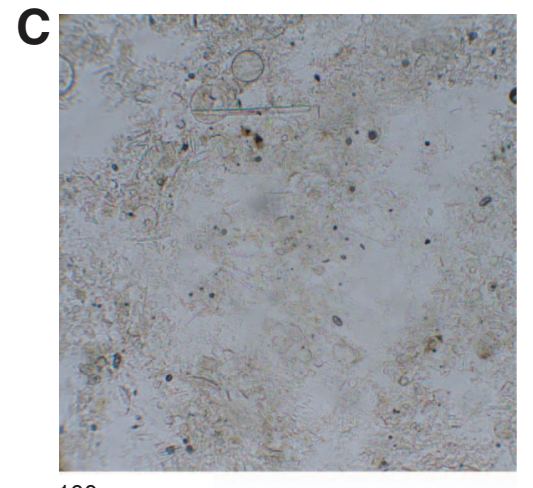

$100 \mu \mathrm{m}$

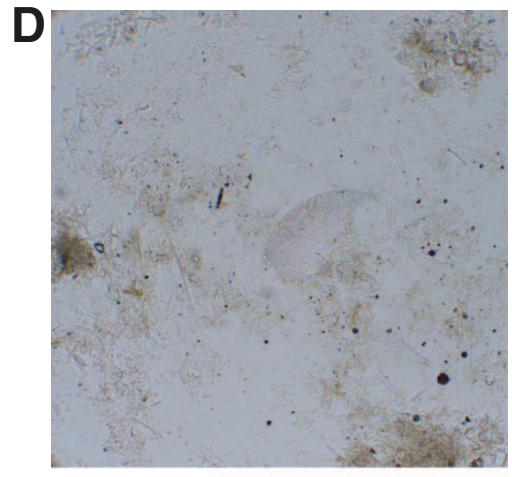

$100 \mu \mathrm{m}$

E

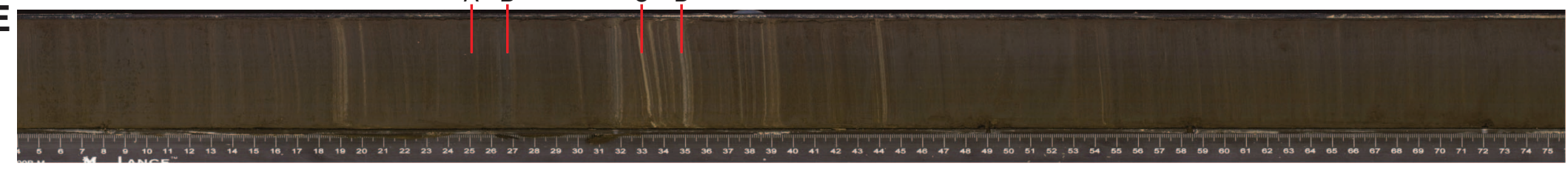


Figure F21. Smear slide images showing typical variations in diatom content. A. Section 346-U1430A-7H-6, $120 \mathrm{~cm}$. B. Section 28H-1, $75 \mathrm{~cm}$. C. Section 28H-2, $145 \mathrm{~cm}$. D. Section 29H-1, $75 \mathrm{~cm}$. E. Section $29 \mathrm{H}-1,96 \mathrm{~cm}$. F. Section $29 \mathrm{H}-3,75 \mathrm{~cm}$. Note that diatoms dramatically decrease deeper than Section $28 \mathrm{H}-2,145 \mathrm{~cm}$.

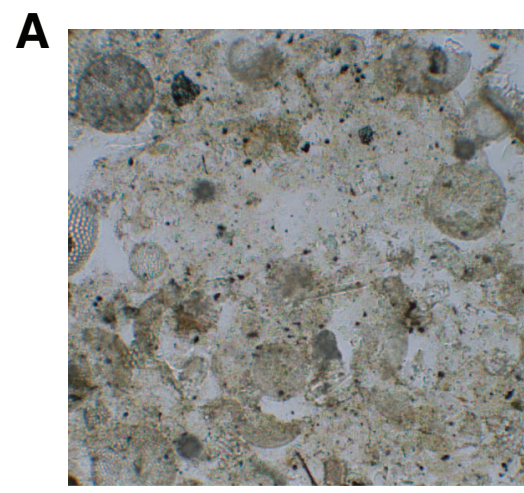

$\underline{100 \mu \mathrm{m}}$

D

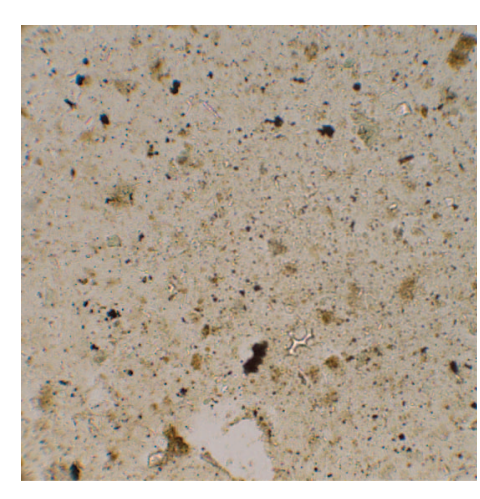

$100 \mu \mathrm{m}$
B

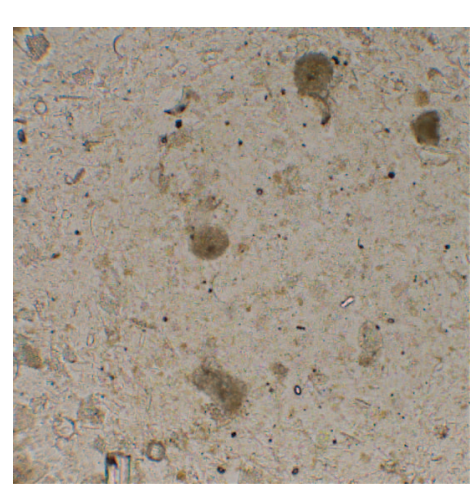

$\underline{100 \mu \mathrm{m}}$

E

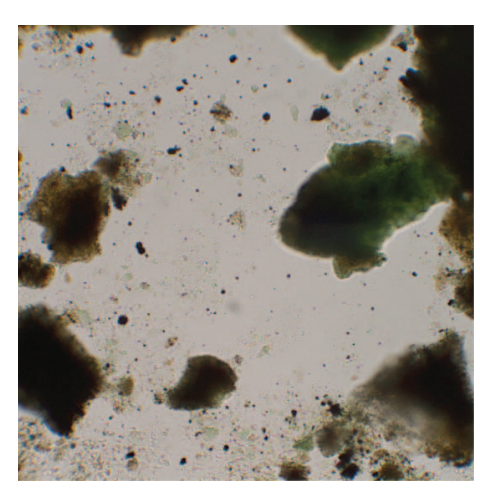

$100 \mu \mathrm{m}$

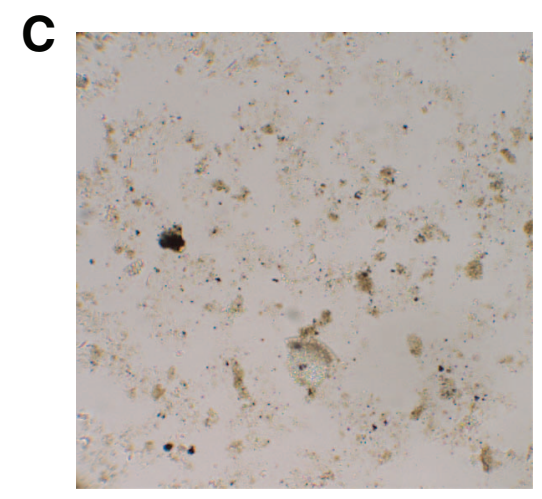

$\underline{100 \mu \mathrm{m}}$

$F$

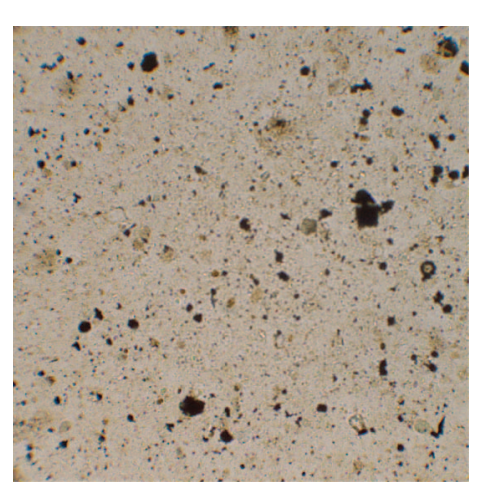

$100 \mu \mathrm{m}$ 
Figure F22. (A) Glauconite-quartz sandstone image (interval 346-U1430A-30X-CC, $22-23$ cm) and (B) corresponding XRD diffractogram. Note the presence of quartz, feldspar, and smectite peaks.
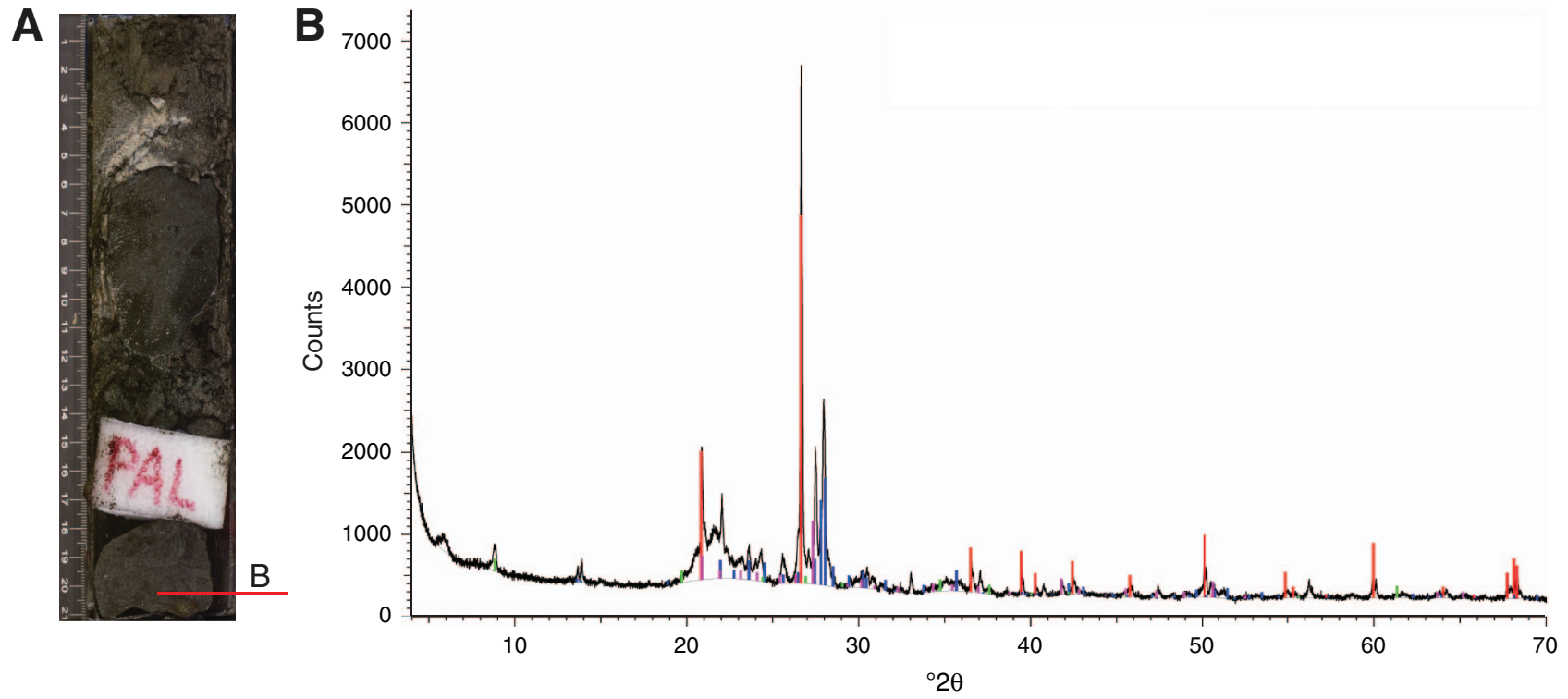
Raw
I Quartz, low
I Anorthite, Na-rich, disordered
I Microcline
| Glauconite 
Figure F23. (A) Glauconite-dolomite sandstone image (interval 346-U1430A-32X-CC, 16-18 cm) and (B) corresponding XRD diffractogram. Note the presence of dolomite and smectite and the much lower intensity of quartz/feldspar peaks in comparison with glauconite-quartz sandstone.
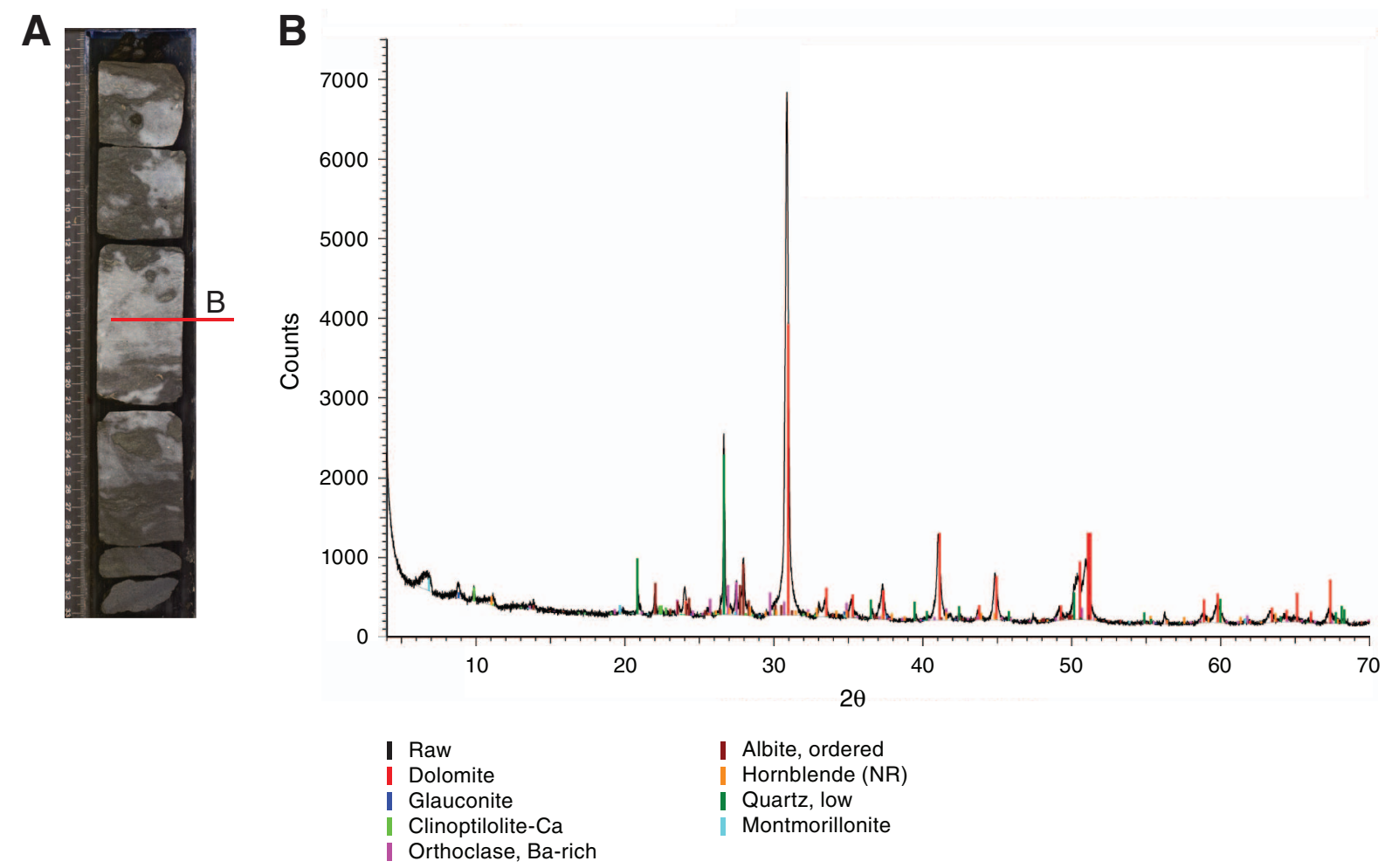
Figure F24. A-D. Thin section images of glauconite sandstone from Unit IV (interval 346-U1430C-32H-CC, 19$21 \mathrm{~cm})$. Note that glauconite fills in and retains the original diatom texture.
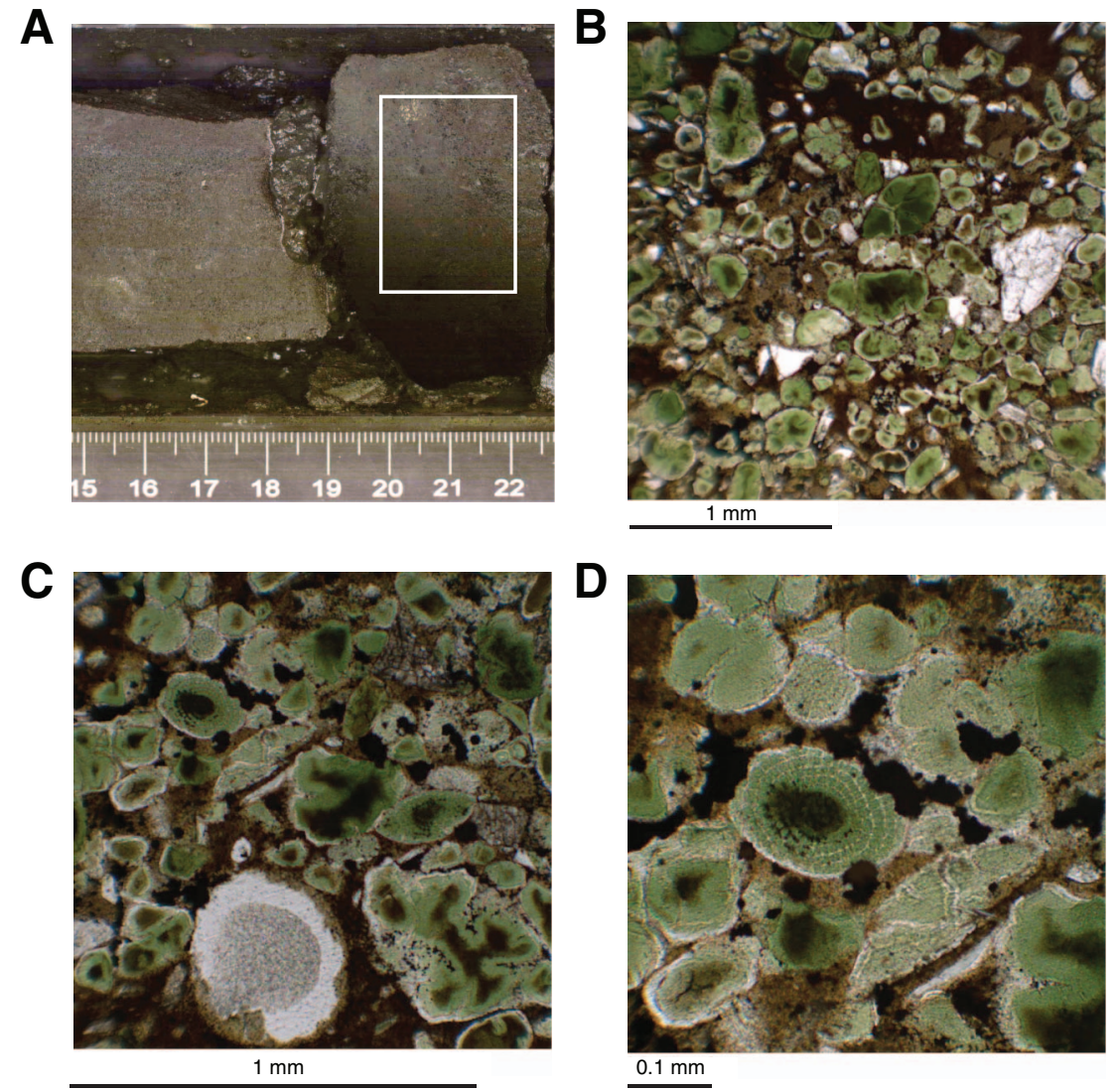
Figure F25. A-D. Smear slide images showing examples of tephra alteration. E. Full section image (Section 346-U1430B-33X-1). C is under crossed nicols. The edges of the volcanic glass in $\mathrm{B}$ and $\mathrm{C}$ are altered and have become indistinct. In $\mathrm{D}$, nearly all volcanic glass is dissolved and altered to silicon/clay minerals.

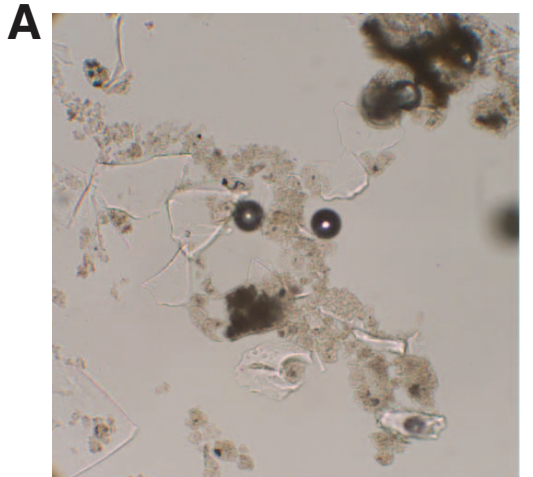

$E$

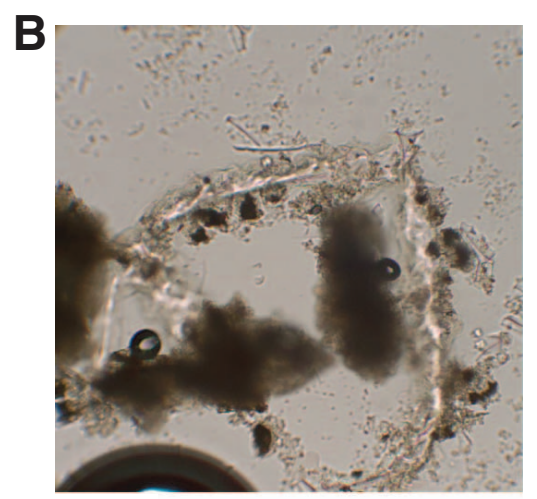

$100 \mu \mathrm{m}$

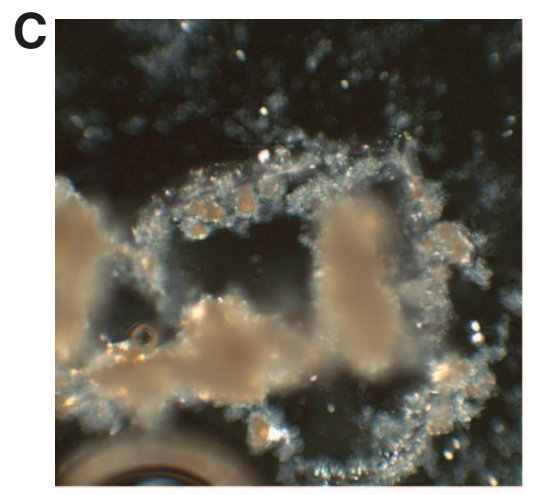

$100 \mu \mathrm{m}$

A

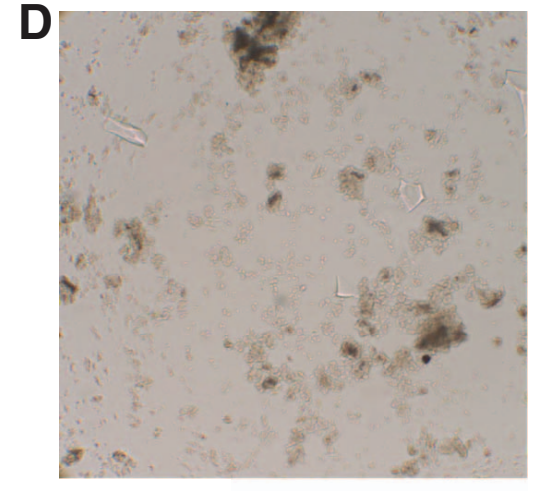

$100 \mu \mathrm{m}$

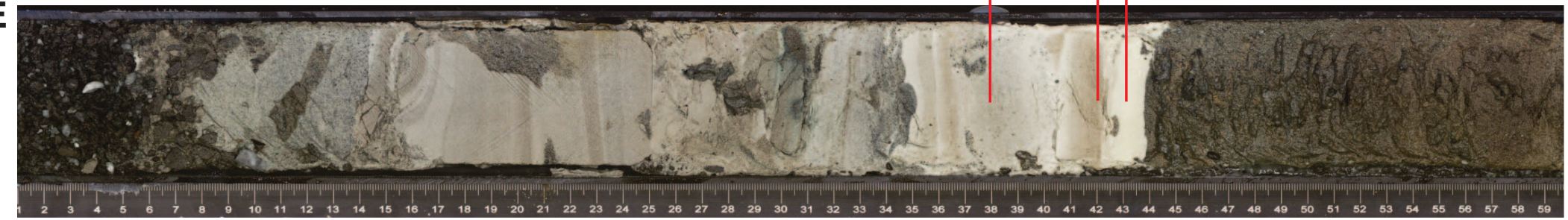


Figure F26. Integrated calcareous and siliceous microfossil biozonation, Site U1430. Note: Depth has been calculated from CCSF-A (Holes U1430A and U1430B) to CSF-A (Hole U1430A).

Hole U1430A

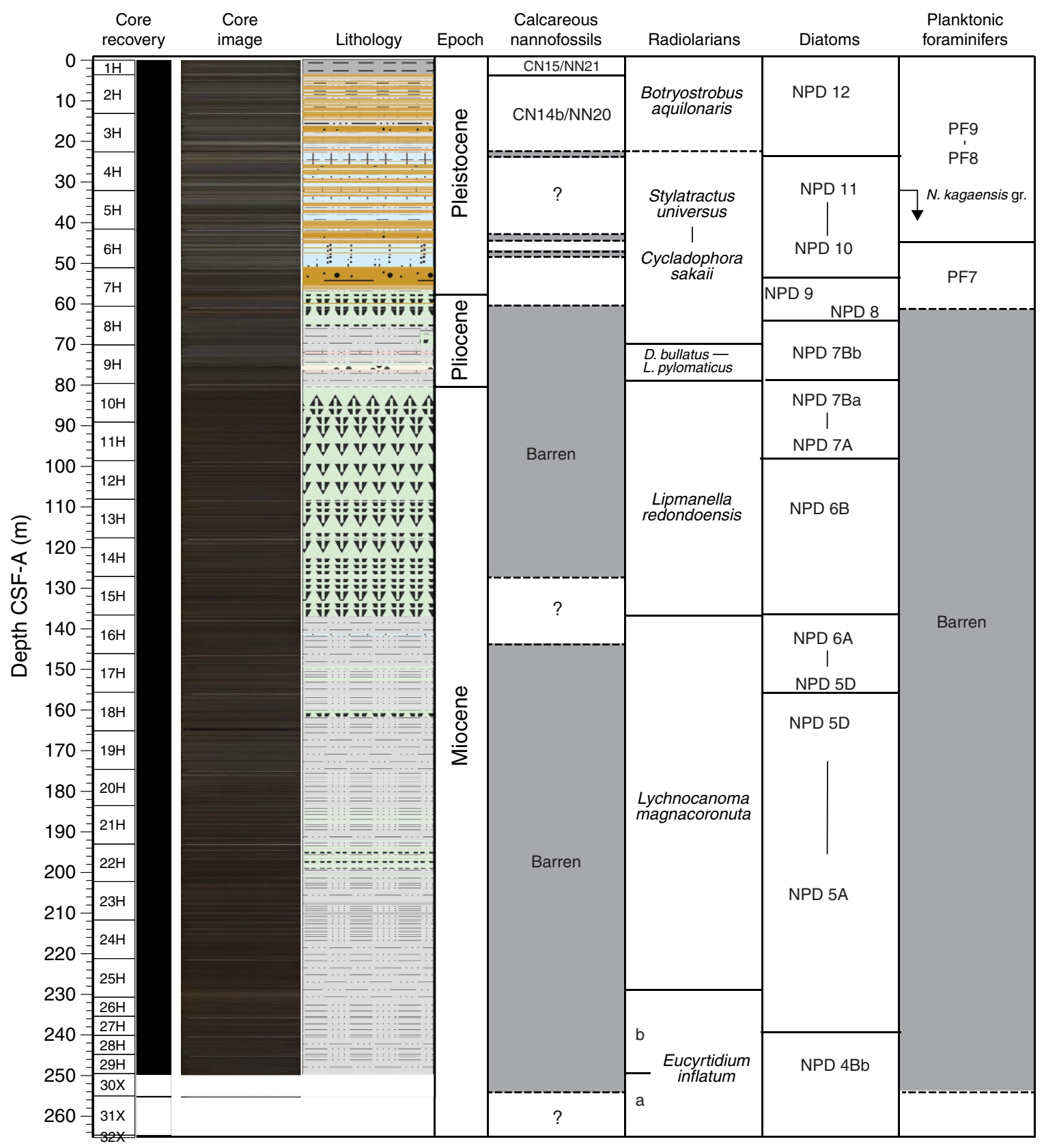


Figure F27. Age-depth profile, Site U1430. FO = first occurrence, LO = last occurrence, RD = rapid decrease, LCO $=$ last common occurrence, $\mathrm{FCO}=$ first common occurrence.

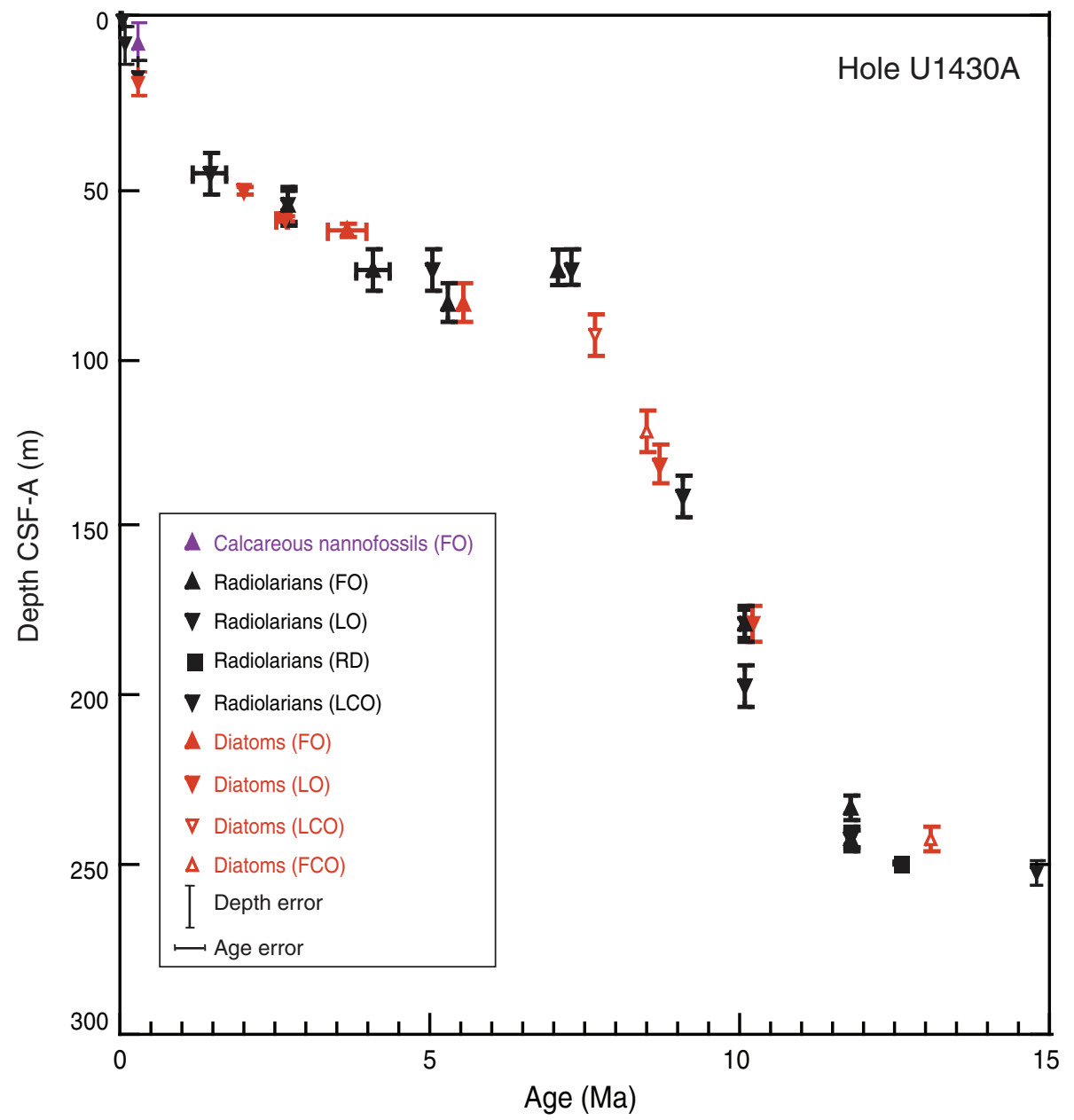


Figure F28. Distribution of siliceous and calcareous microfossils at Site U1430. B = barren, $\mathrm{R}=$ rare, $F=$ few, $C=$ common, $A=$ abundant, $D=$ dominant.

Site U1430

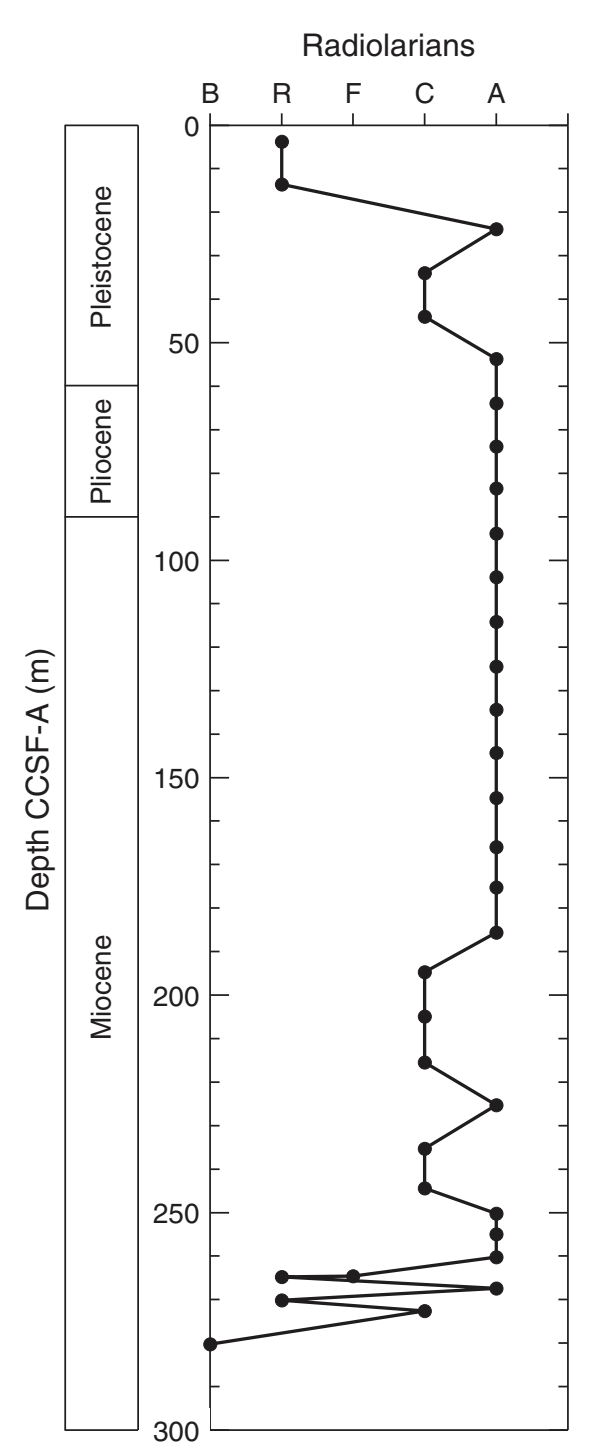

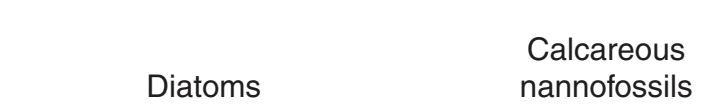

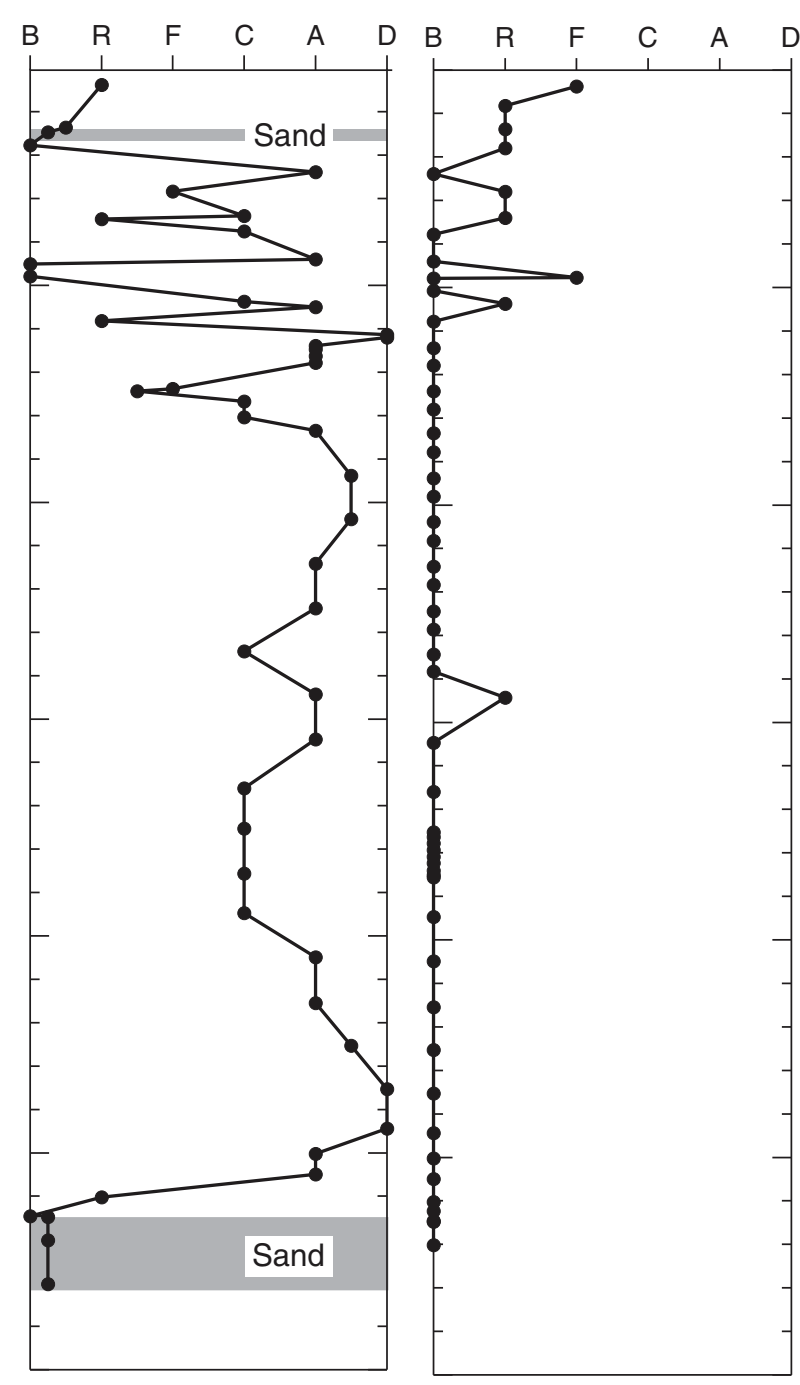

Planktonic foraminifers $/ 30 \mathrm{~cm}^{3}$

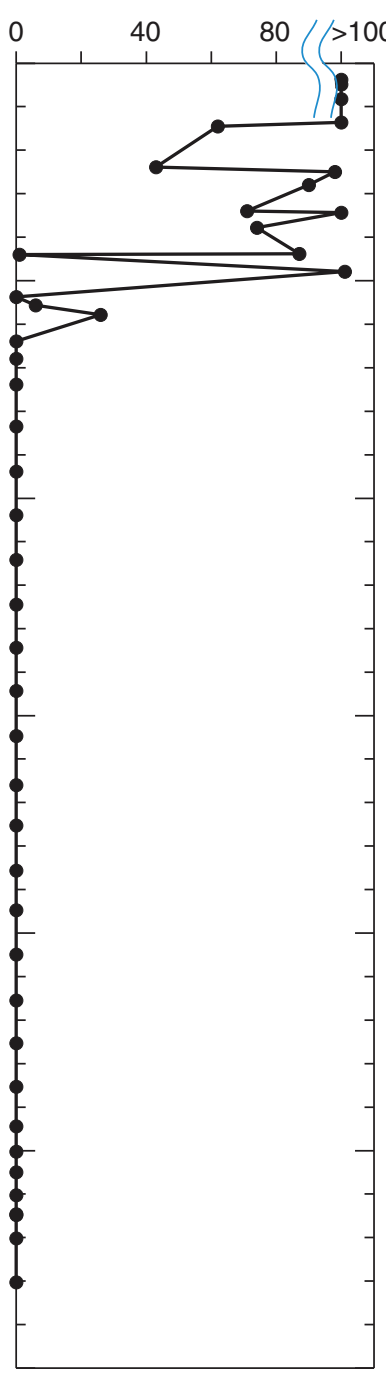

Benthic foraminifers $/ 30 \mathrm{~cm}^{3}$

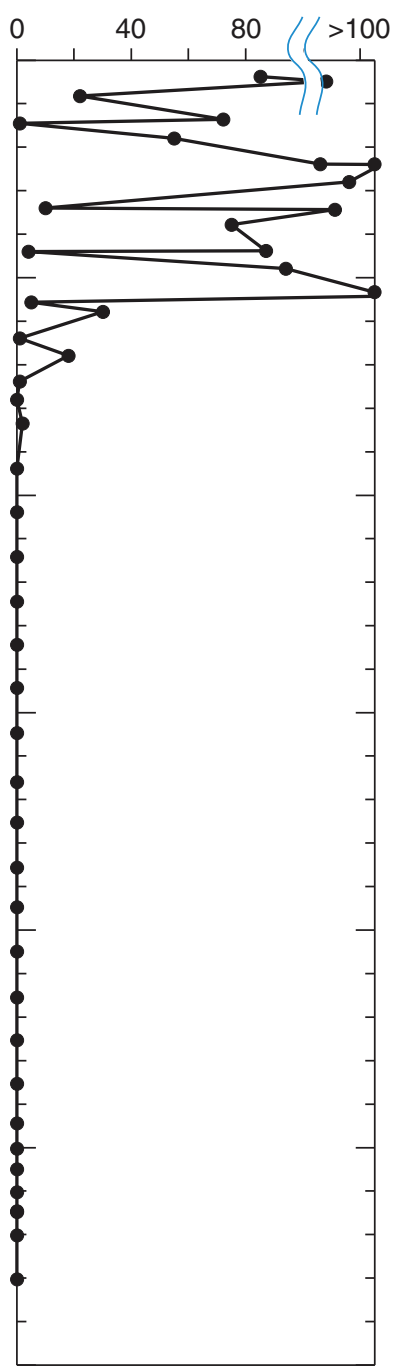



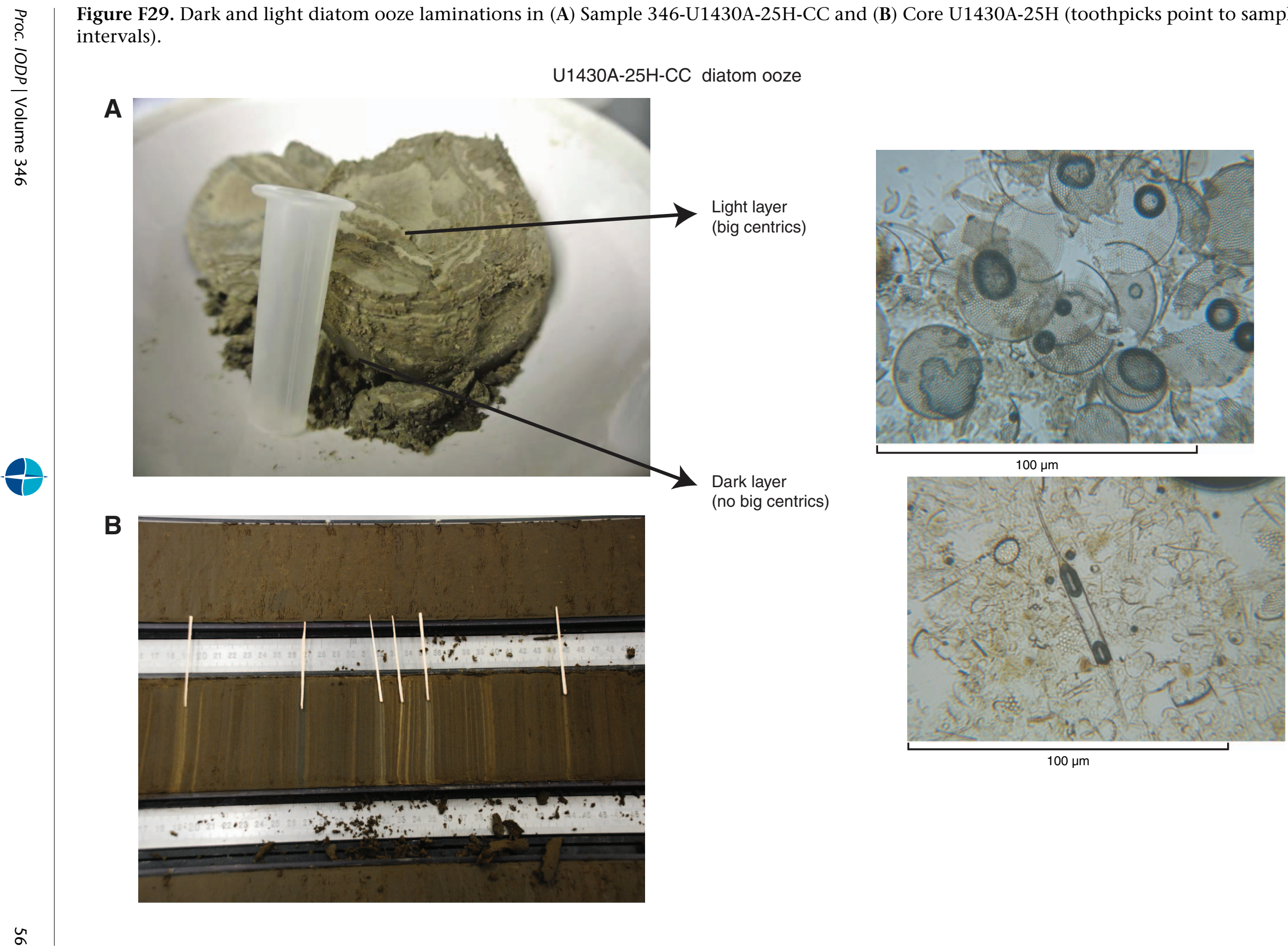
Figure F30. Distribution of benthic foraminifers in Hole U1430A showing percentage of various calcareous species as percentage of the total benthic assemblage.

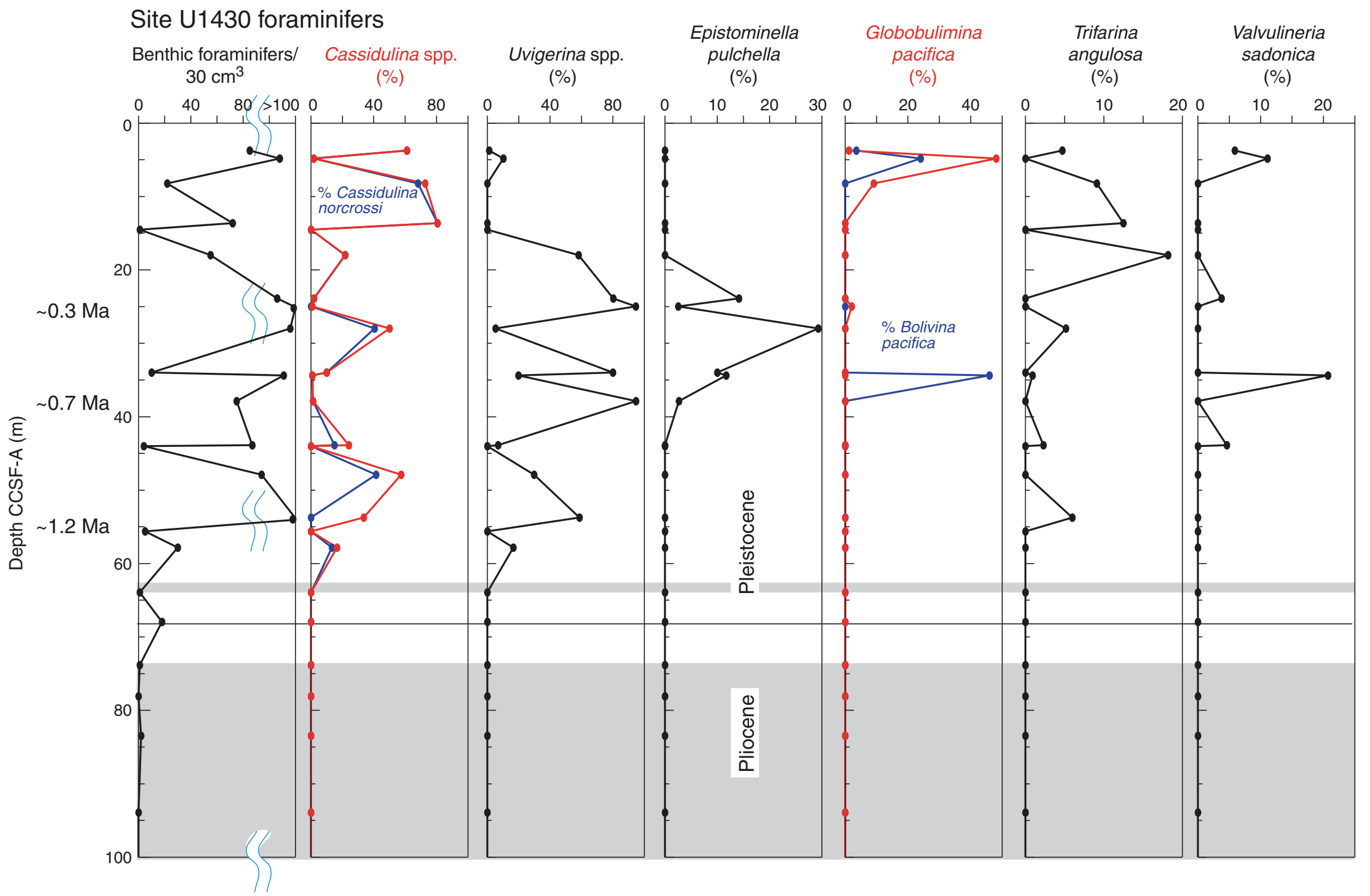


Figure F31. Calcareous and organically cemented, agglutinated foraminifers from the Hole U1430A mudline sample. Scale bars $=100 \mu \mathrm{m}$. 1. Hyperammina elongata. 2. Jaculella acuta. 3-6. Reophax scorpiurus. 7, 8. Bolivina pacifica. 9. Bolivina robusta. 10, 11. Trifarina angulosa. 12, 13. Miliammina echigoensis. 14. Robertinoides bradyi. 15. Quinqueloculina sp. 16. Nummoloculina sp. 17. Pyrgoella sp. 18. Pyrgo sp.

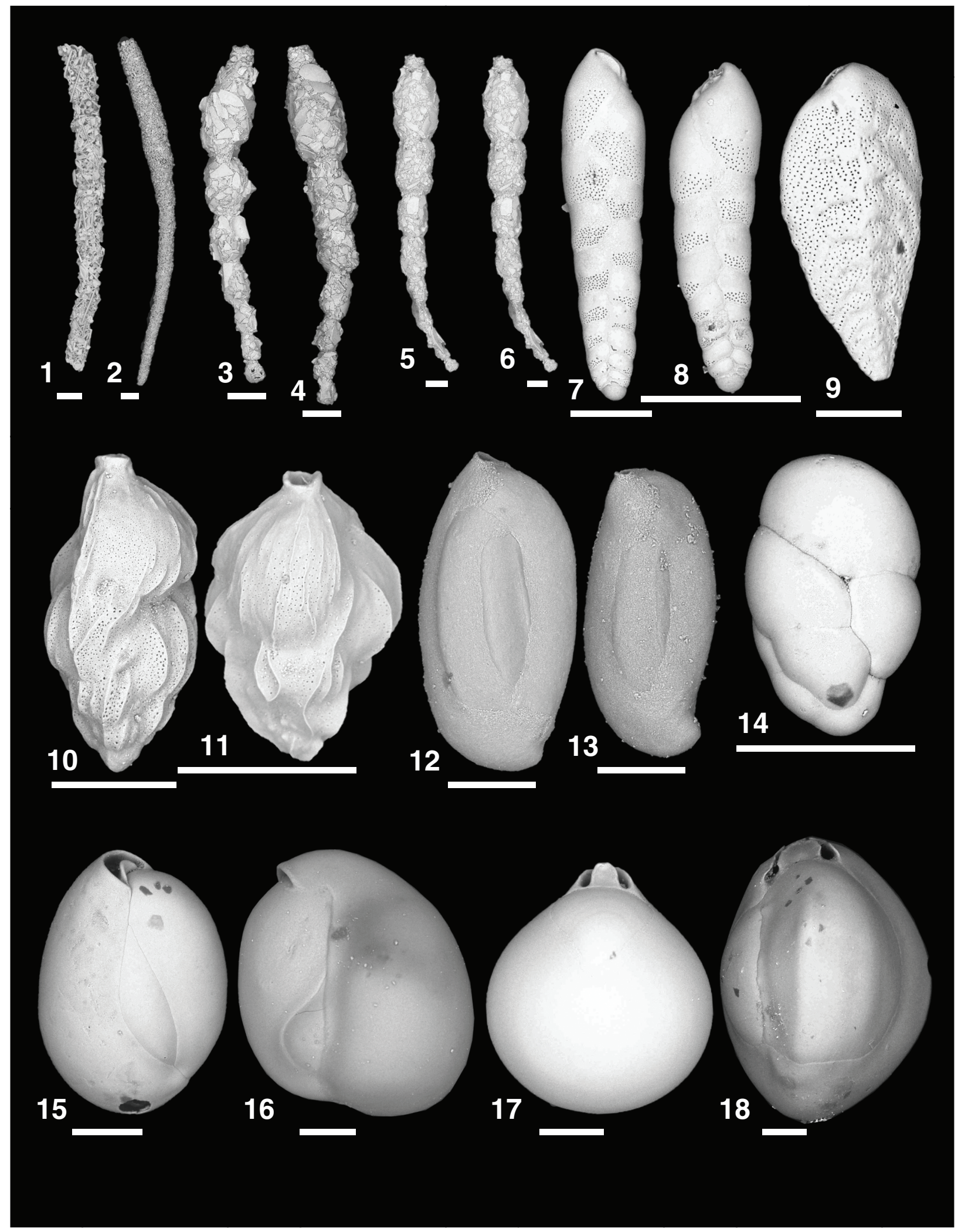


Figure F32. Calcareous and organically cemented, agglutinated foraminifers from the Hole U1430A mudline sample. Scale bars $=100 \mu \mathrm{m}$. 1-3, 5. Cribrostomoides subglobosus. 4. Glomospira charoides. 6, 7. Haplophragmoides sp. 8, 9. Haplophragmoides subsphaericum. 10, 11. Paratrochammina challenger. 12. Cassidulina japonica. 13. Cibicidoides mundulus.

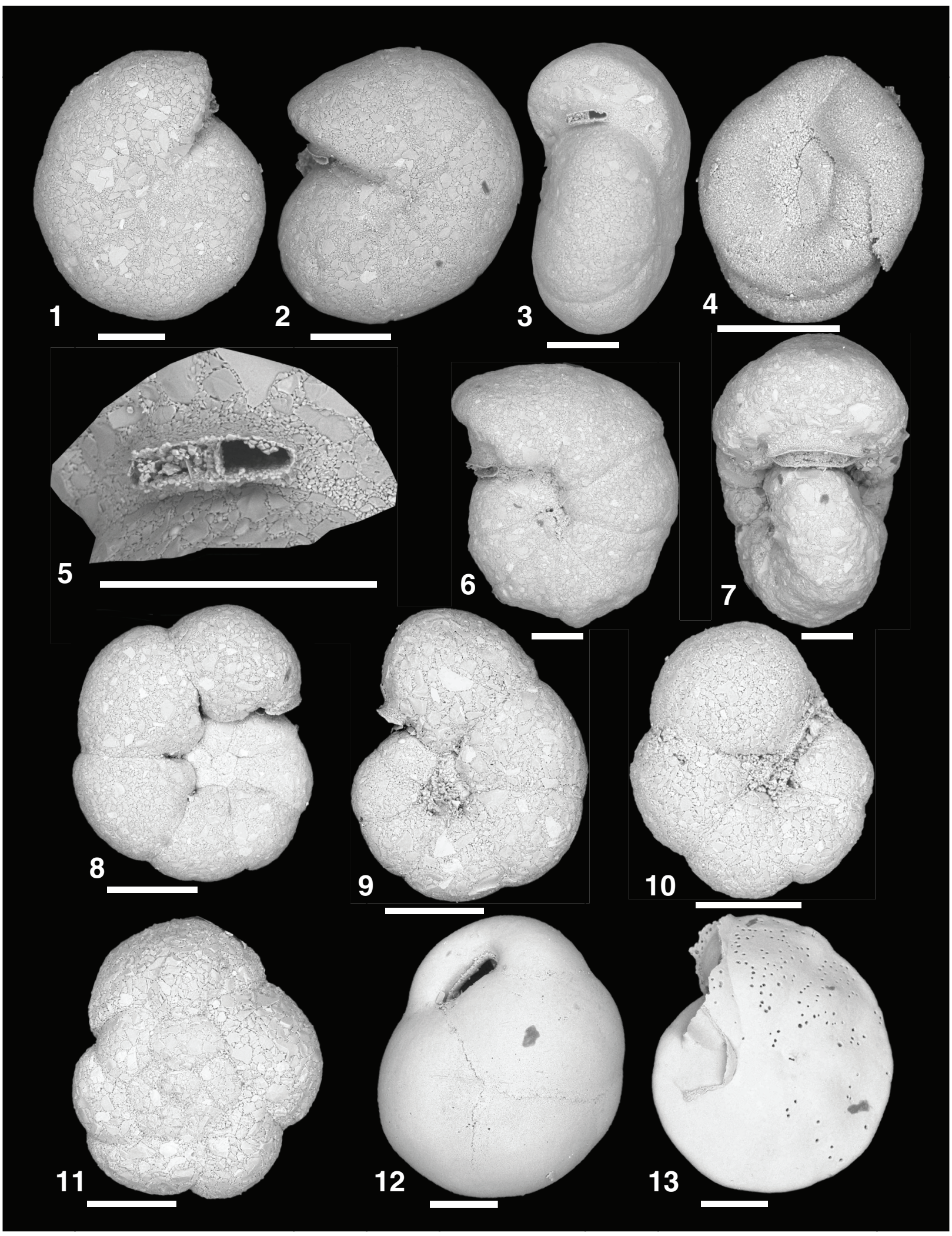


Figure F33. Dissolved alkalinity, ammonium, and phosphate profiles over the full depth, Site U1430. Constructed using squeezed interstitial water (IW-sq) samples.

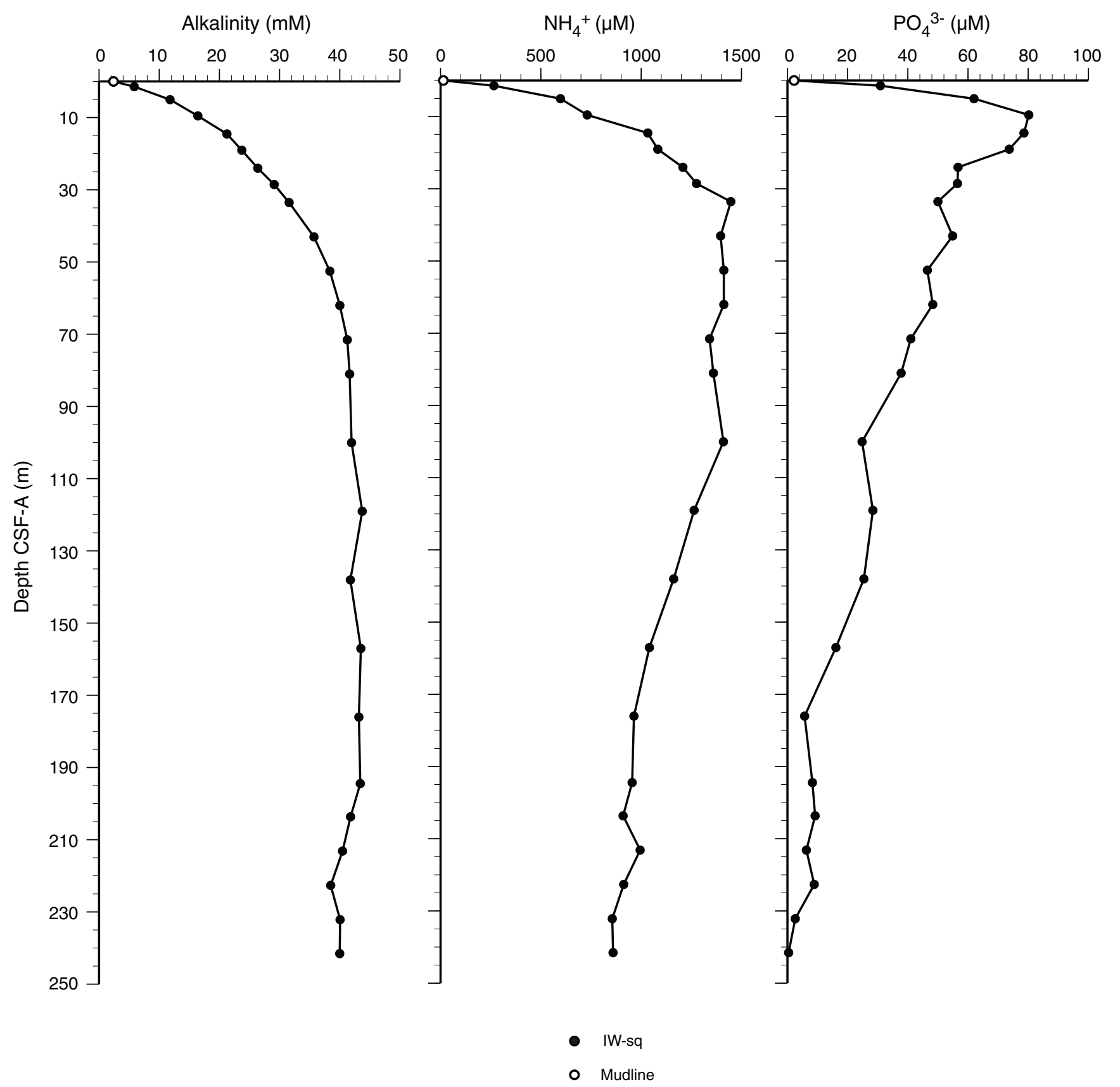


Figure F34. Dissolved calcium, magnesium, and strontium profiles across the full depth, Site U1430.

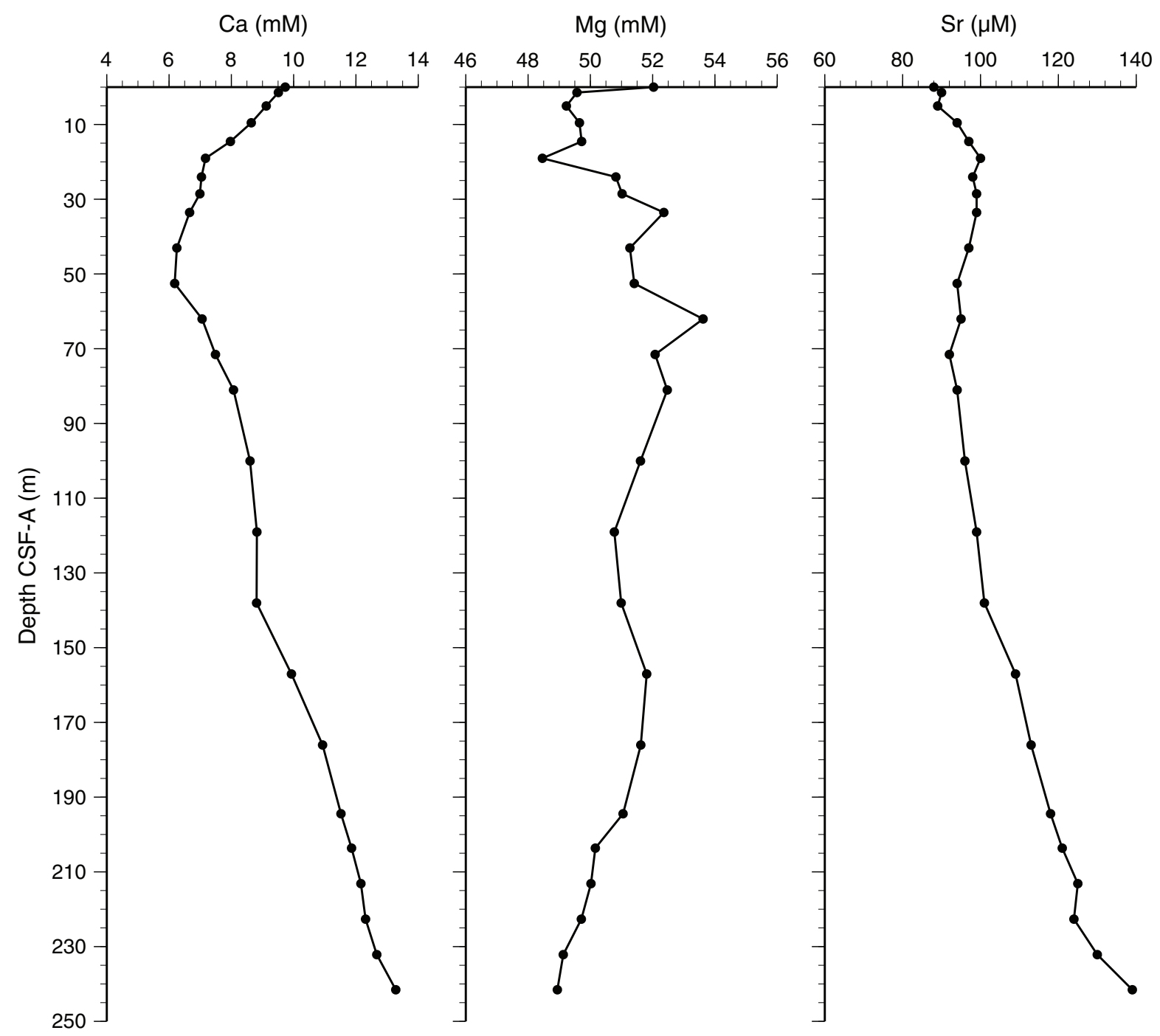


Figure F35. Dissolved sulfate concentrations, Site U1430. Also shown are headspace $\mathrm{CH}_{4}$ concentrations (on a linear scale).

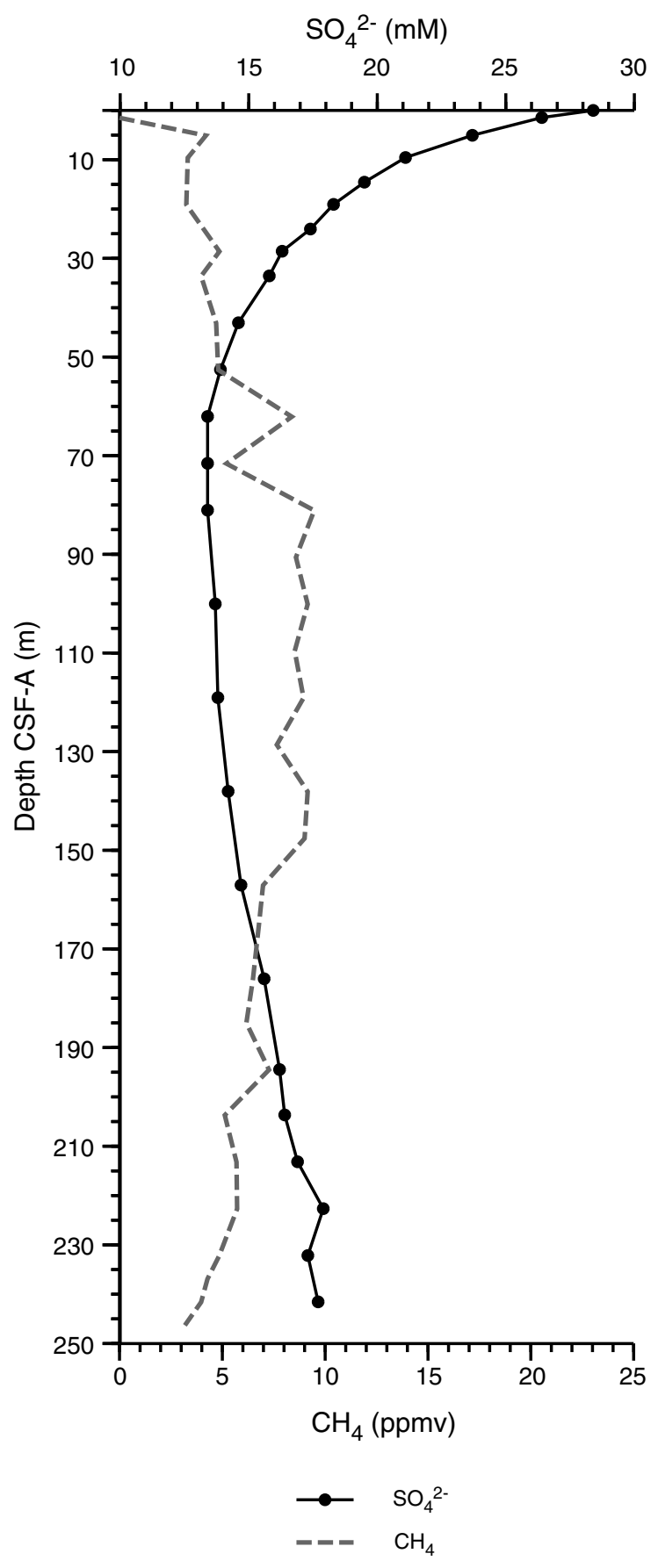


Figure F36. Headspace $\mathrm{CH}_{4}$ concentrations with depth at Site U1430 with other sites plotted for comparison. Note the very low concentration at Site U1430, compared to other Expedition 346 sites.

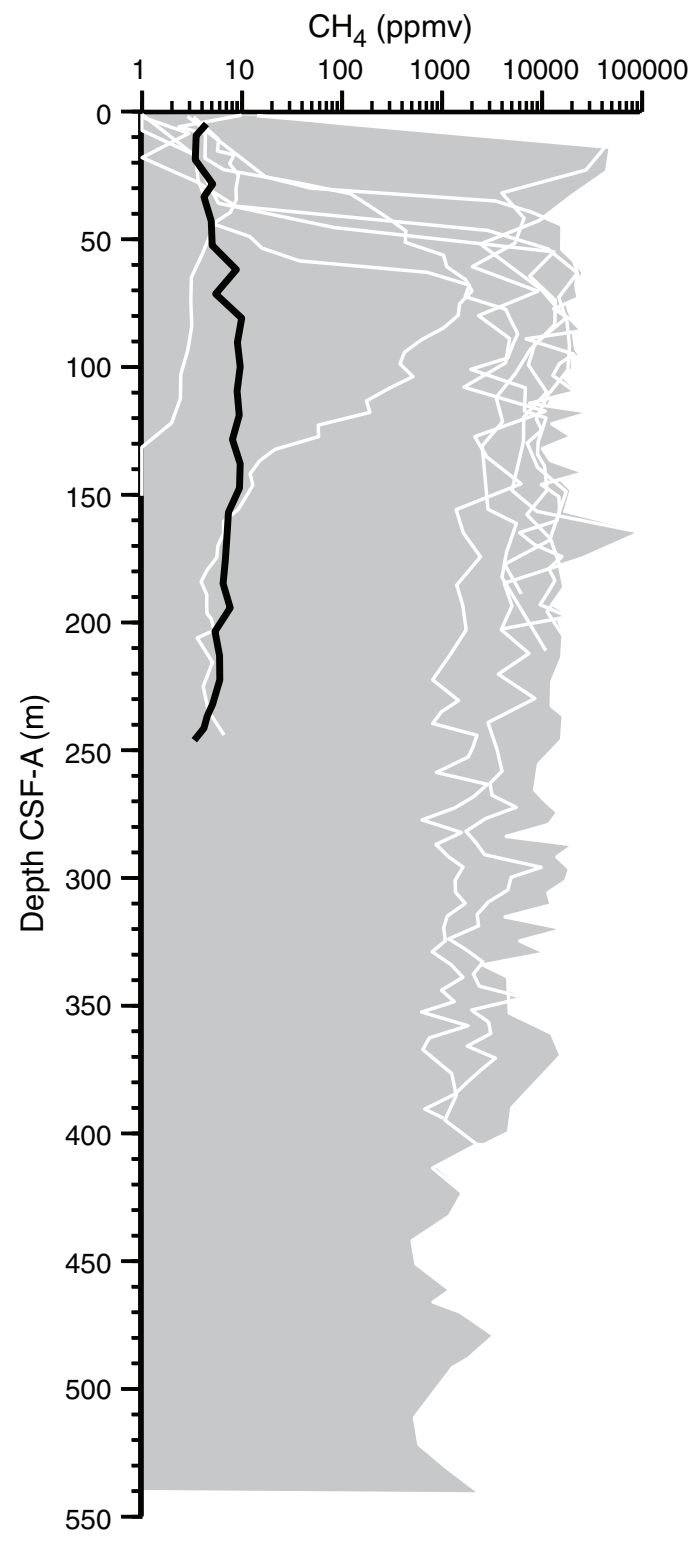


Figure F37. Solid-phase contents of discrete sediment samples, Site U1430. TOC = total organic carbon, TN = total nitrogen.

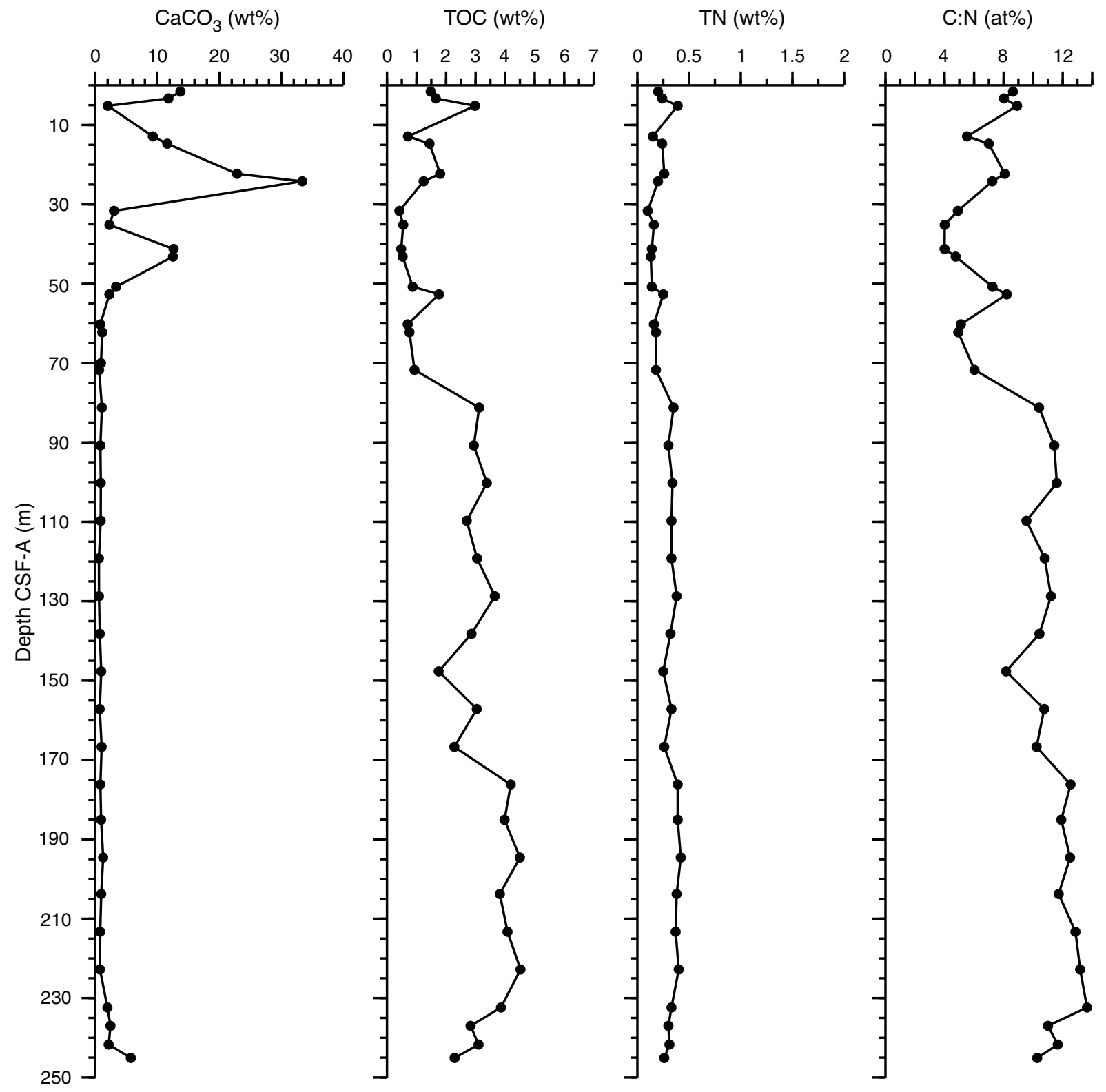


Figure F38. Dissolved manganese and iron profiles over the entire depth from squeezed samples only, Site U1430.

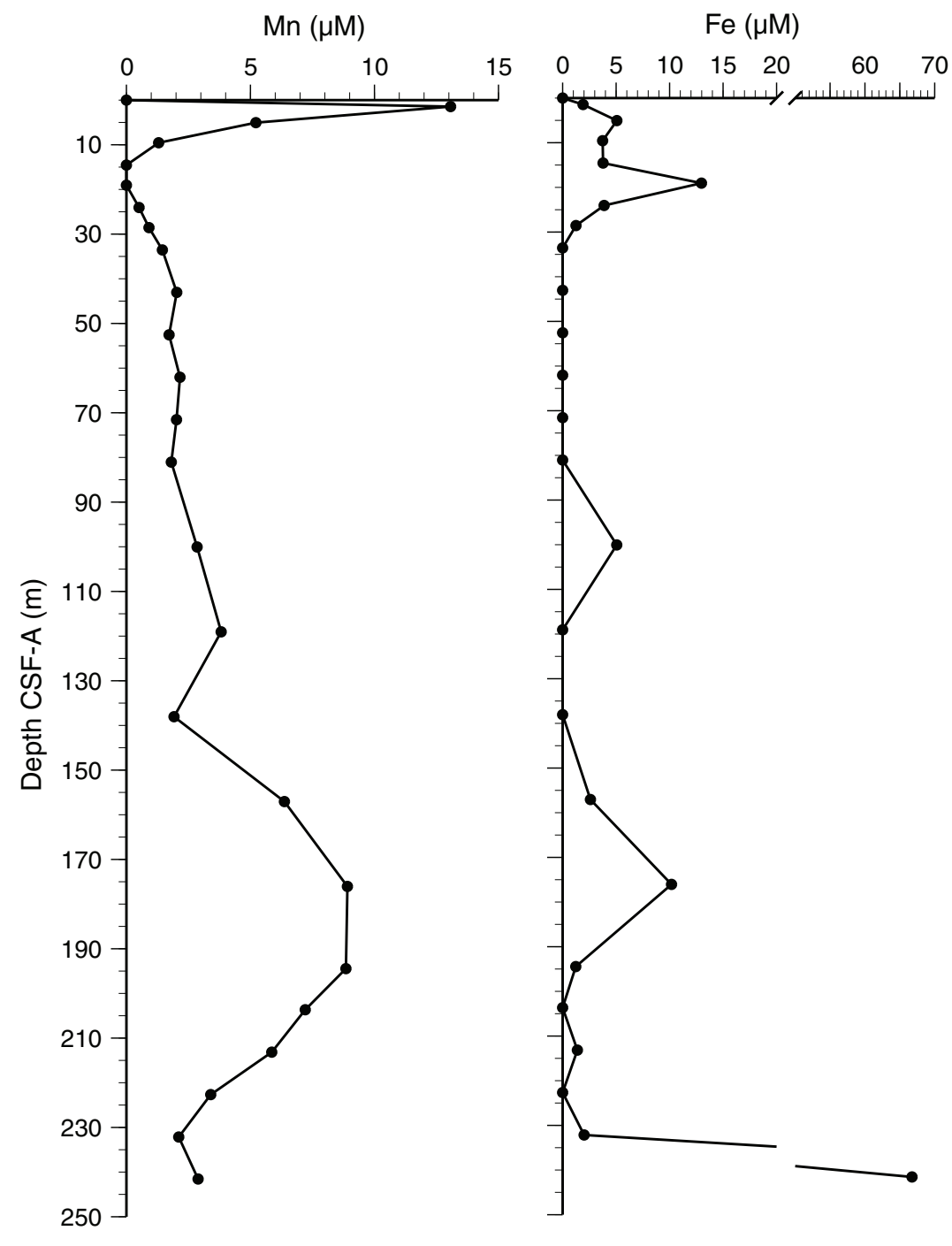


Figure F39. Dissolved boron, lithium, and silica profiles across the full depth from squeezed samples only, Site U1430.

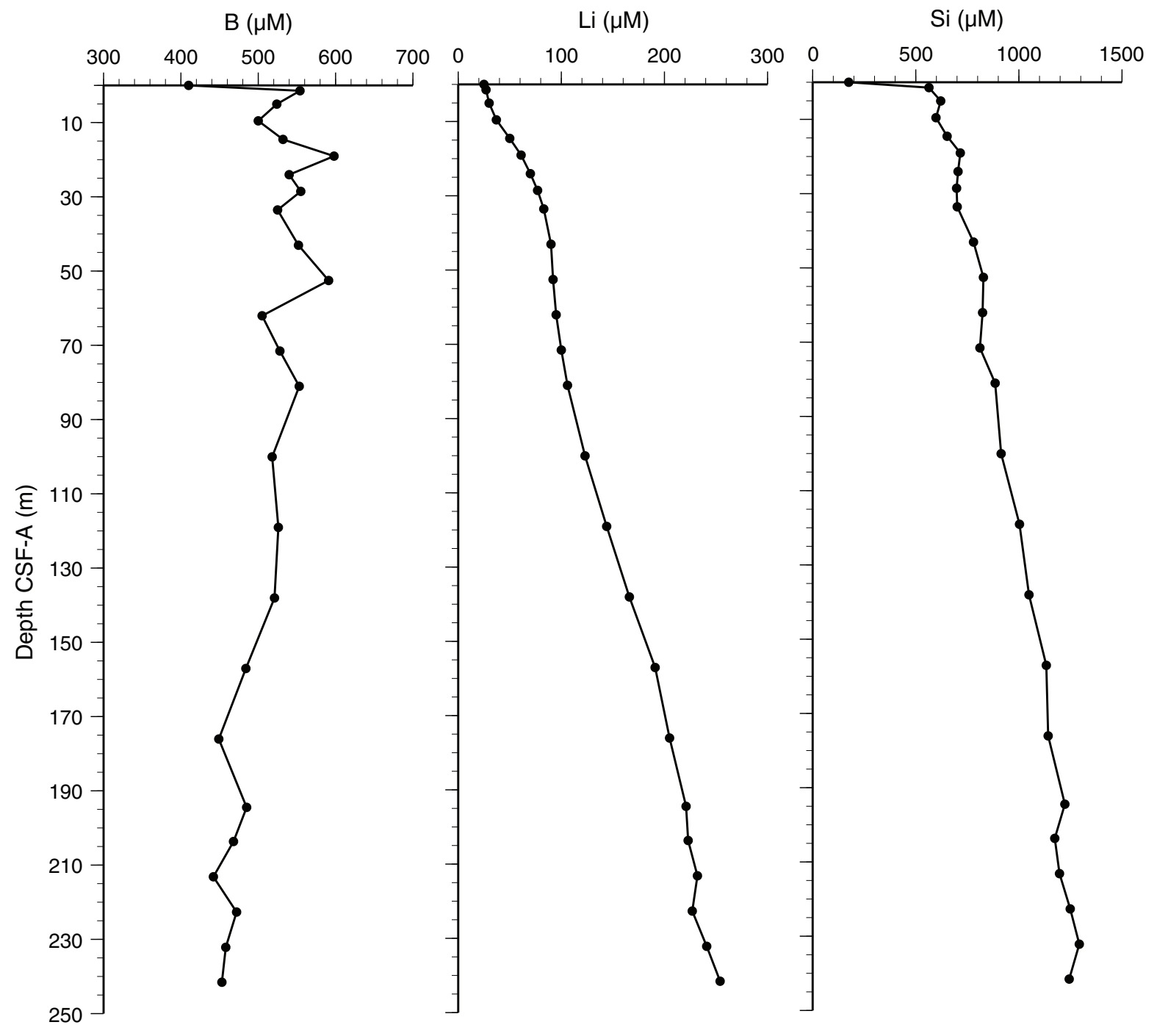


Figure F40. Dissolved chloride, sodium, and bromine profiles across the full depth, Site U1430.

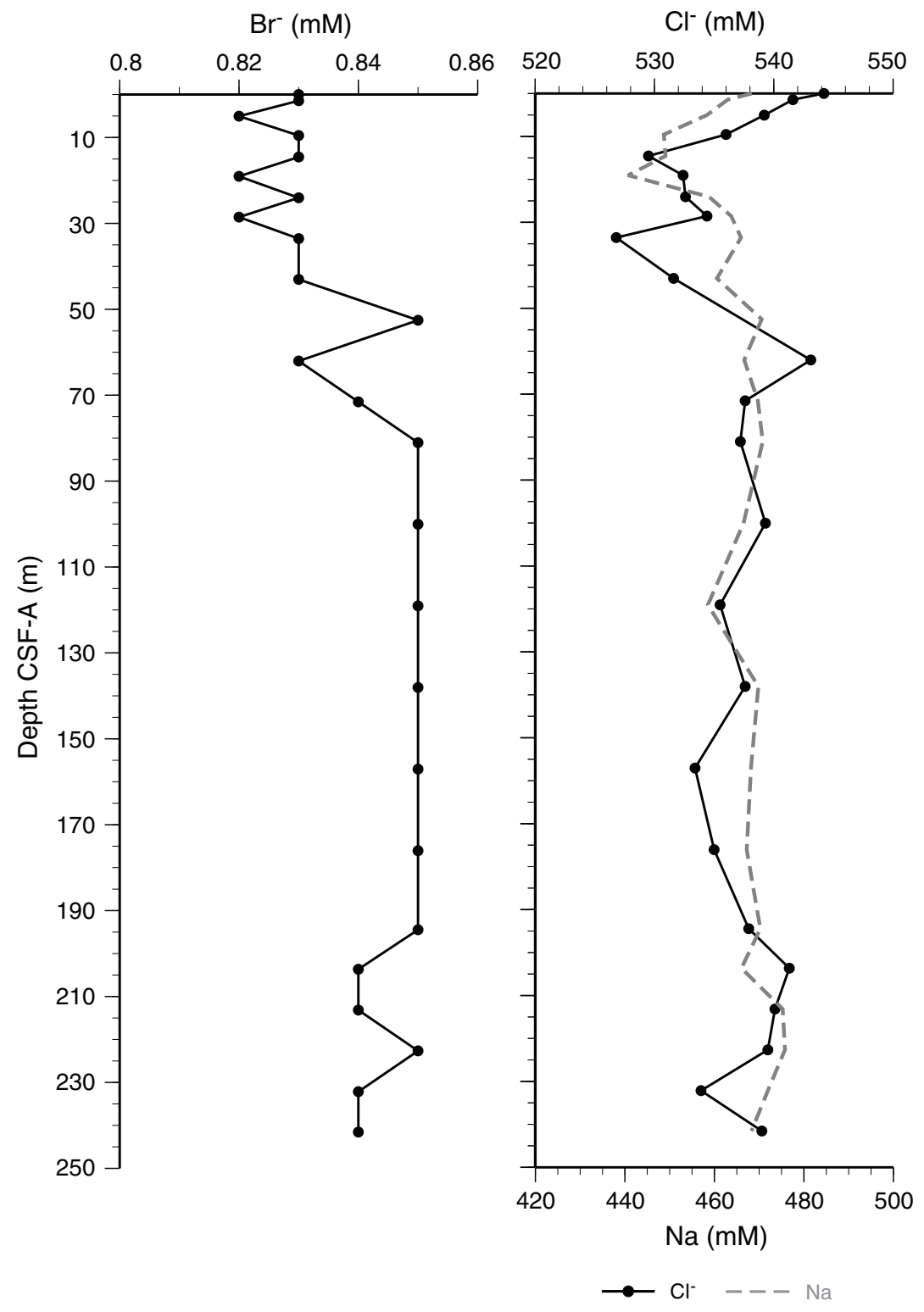


Figure F41. Paleomagnetism after $20 \mathrm{mT}$ AF demagnetization, Site U1430. Chron column: black = normal polarity, white = reversed polarity, gray = zones or polarity boundaries without clear magnetostratigraphic interpretation. Inclination column: thin black dashed lines = expected geocentric axial dipole inclinations at the site latitude during reversed (left) and normal (right) polarities, triangles along the left side mark depths where discrete paleomagnetic cube samples were collected (orange = discrete samples measured during the expedition). Declination column: gray dots $=$ measured declination values, green dots $=$ declination values corrected using core orientation data collected by the FlexIT tool. Susceptibility column: SHMSL and WRMSL measured values are shown in magenta and gray dots, respectively. A. Hole U1430A. (Continued on next two pages.)

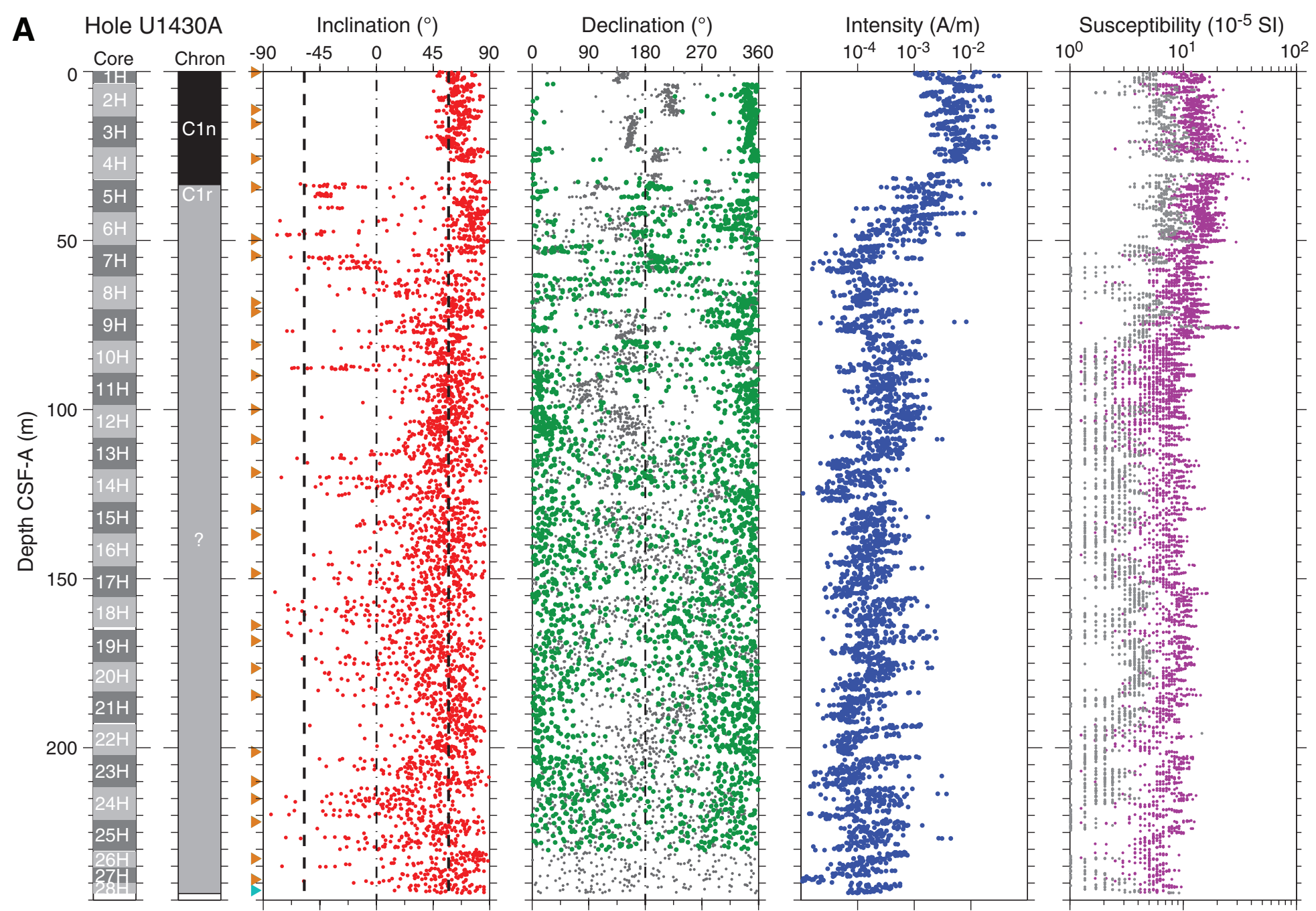


Figure F41 (continued). B. Hole U1430B. (Continued on next page.)

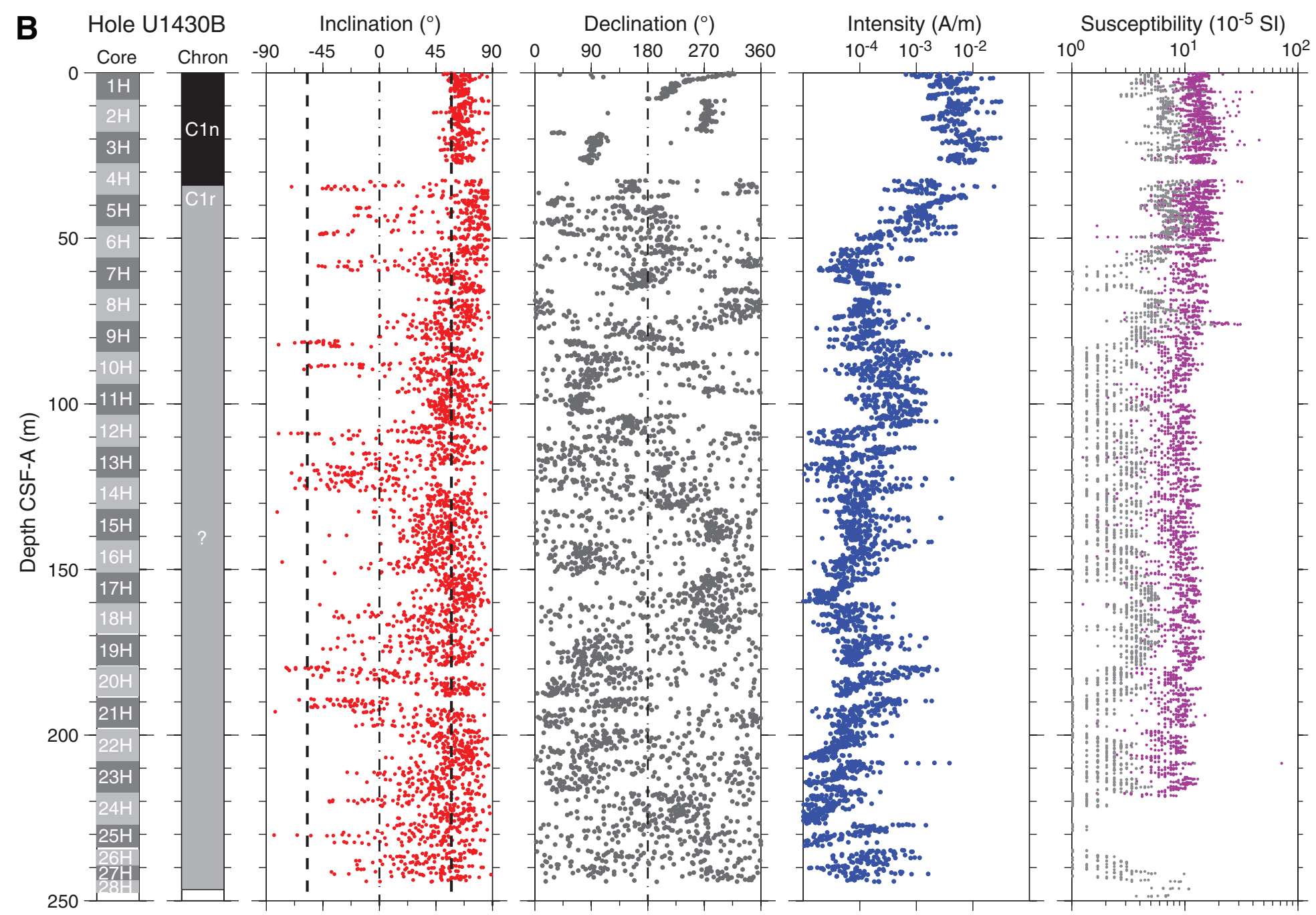


Figure F41 (continued). C. Hole U1430C.

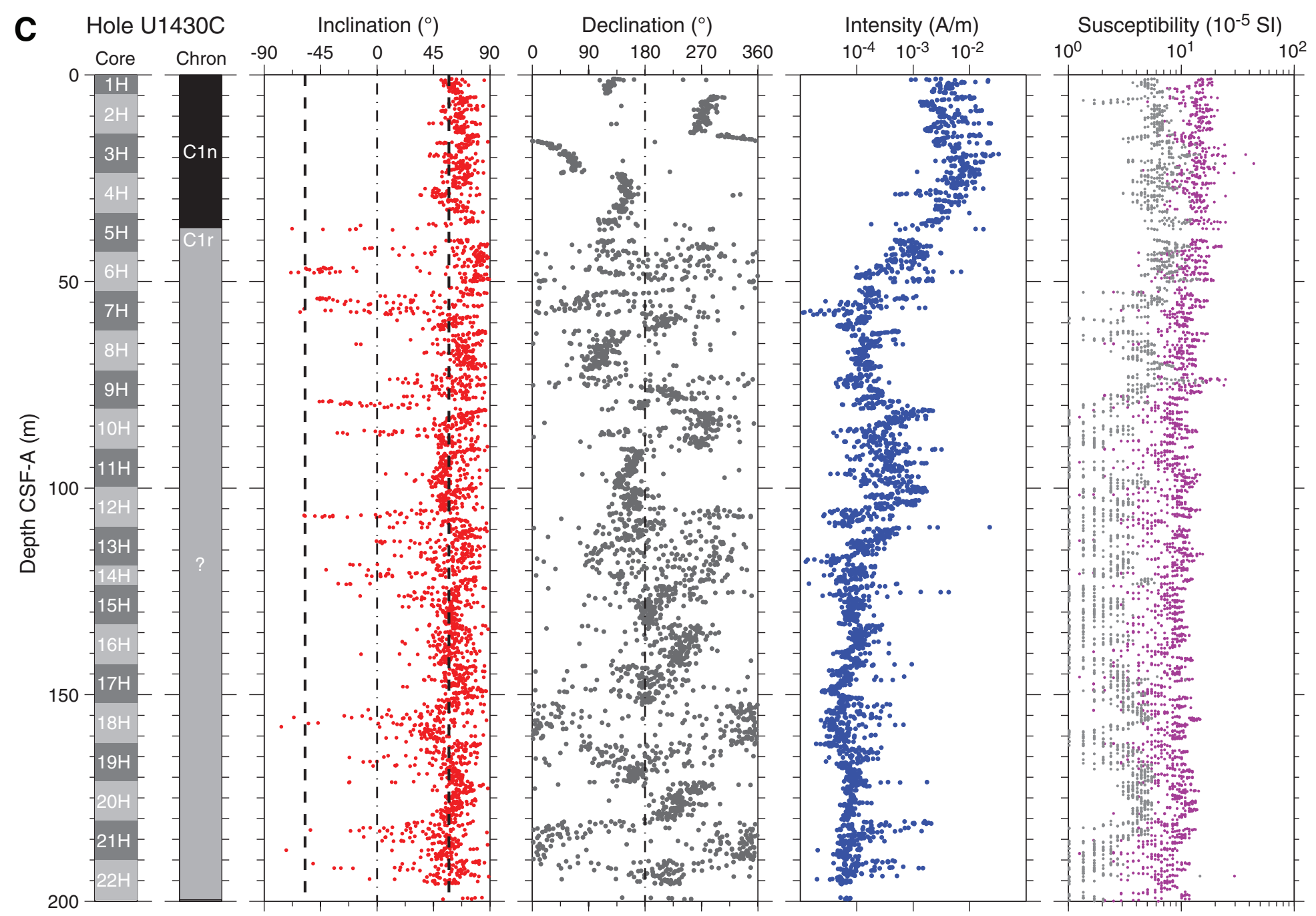


Figure F42. AF demagnetization results for discrete samples, Hole U1430A. For each sample, the left plot shows the intensity variation with progressive demagnetization. The middle and right plots show the NRM vector measured after each demagnetization treatment on an orthogonal projection (Zijderveld) and on an equal area projection, respectively. In the orthogonal projection plot, squares $=$ horizontal projections, circles $=$ vertical projections. In the equal area projection plot, closed circles $=$ projection data with positive inclinations, open circles $=$ projection data with negative inclinations. Note that on the orthogonal projection (Zijderveld) plot, NRM data before demagnetization have been removed to better display the demagnetized data. A-H. 0.26-68.38 m CSF-A. (Continued on next three pages.)

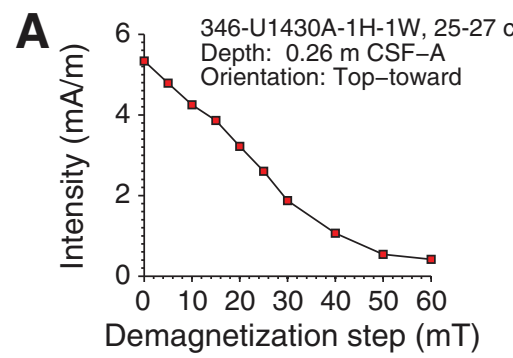

B ${ }^{4} \quad$ 346-U1430A-2H-6W, 25-27 cm

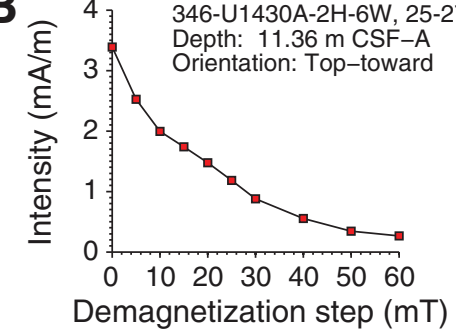

C 5 346-U1430A-3H-2W, 80-82 cm

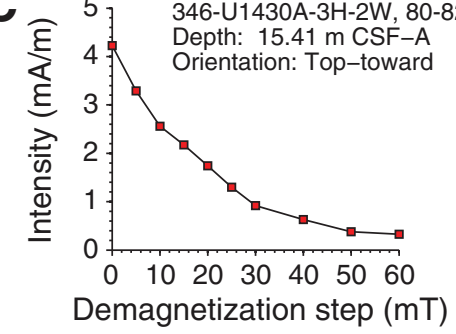

D 12 346-U1430A-4H-3W, 23-25 cm

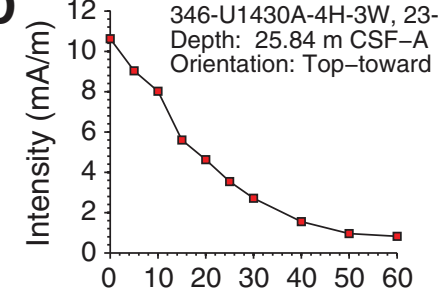

Demagnetization step (mT)
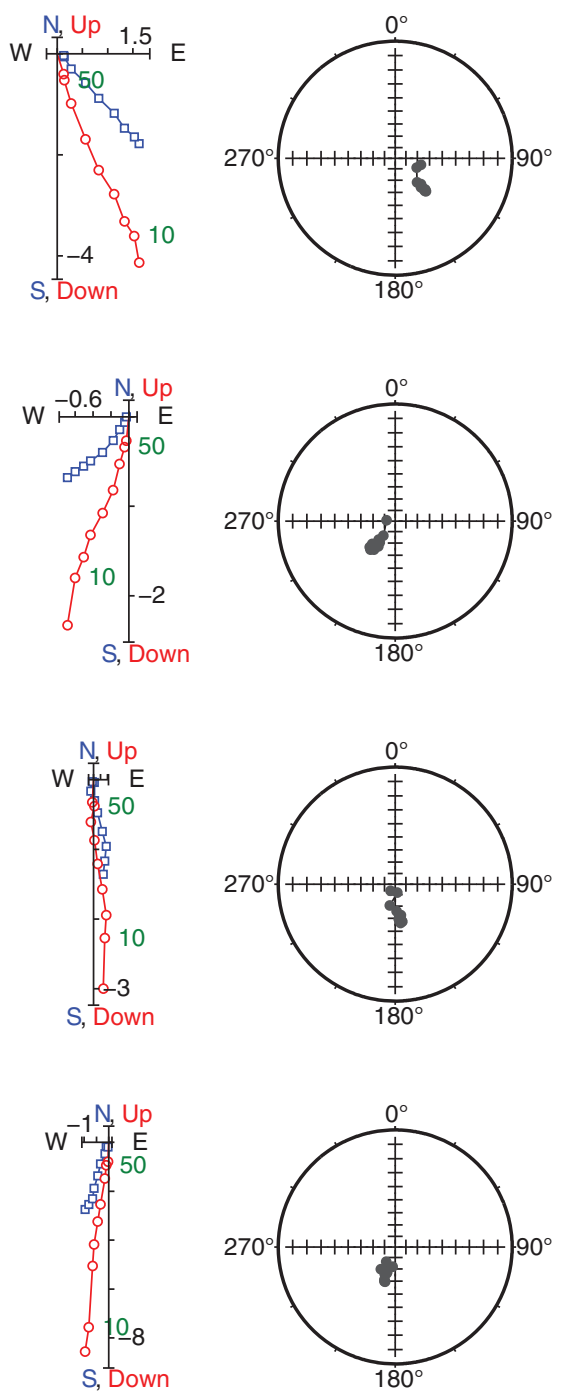

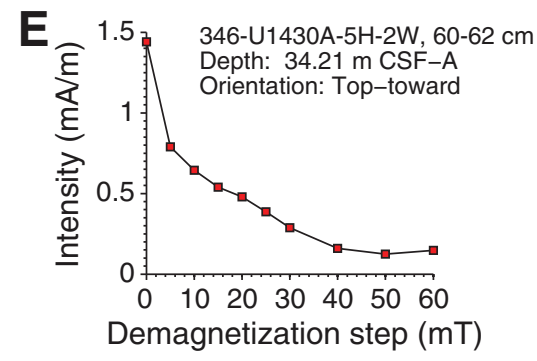

F 2 346-U1430A-6H-6W, 50-52 cm

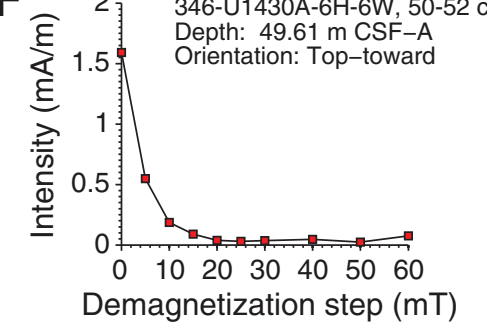

G 1.5 346-U1430A-7H-3W, $38-40 \mathrm{~cm}$

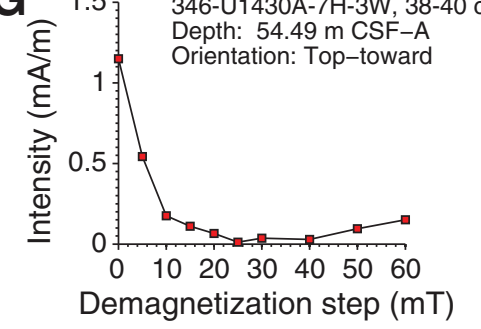

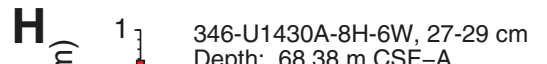

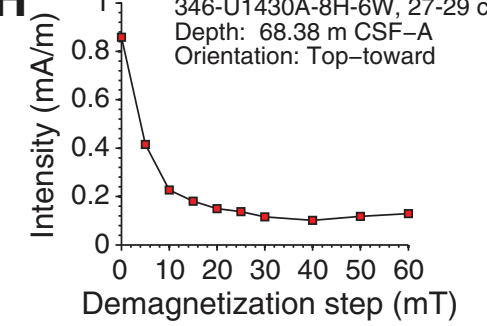

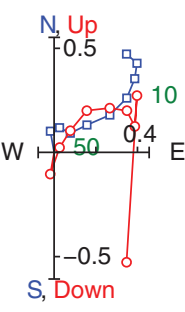
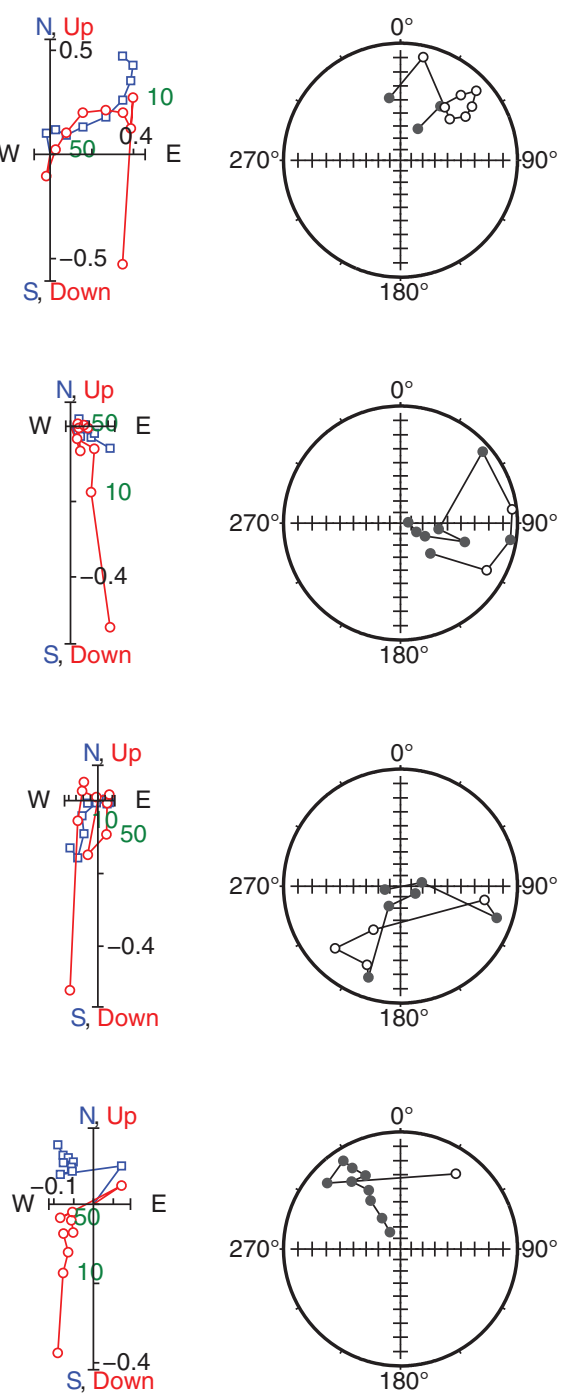
Figure F42 (continued). I-P. 71.03-136.94 m CSF-A. (Continued on next page.)

0.8 346-U1430A-9H-1W, 92-94 cm

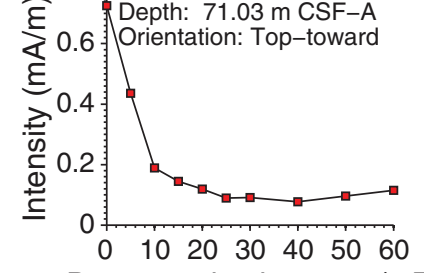

Demagnetization step $(\mathrm{mT})$

J 2 346-U1430A-10H-1W, 122-124 cm

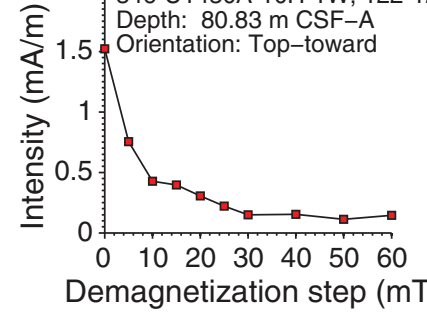

K

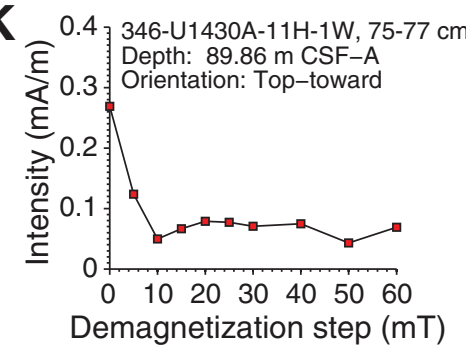

L ${ }^{1.5}$ 3 346-U1430A-12H-1W, $132-134 \mathrm{~cm}$

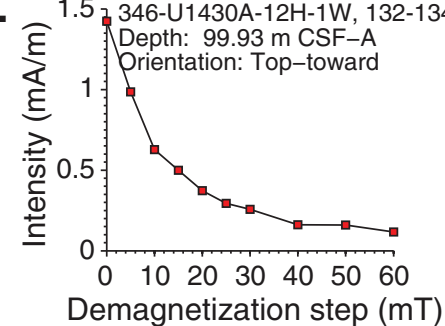

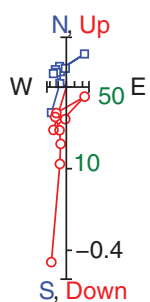
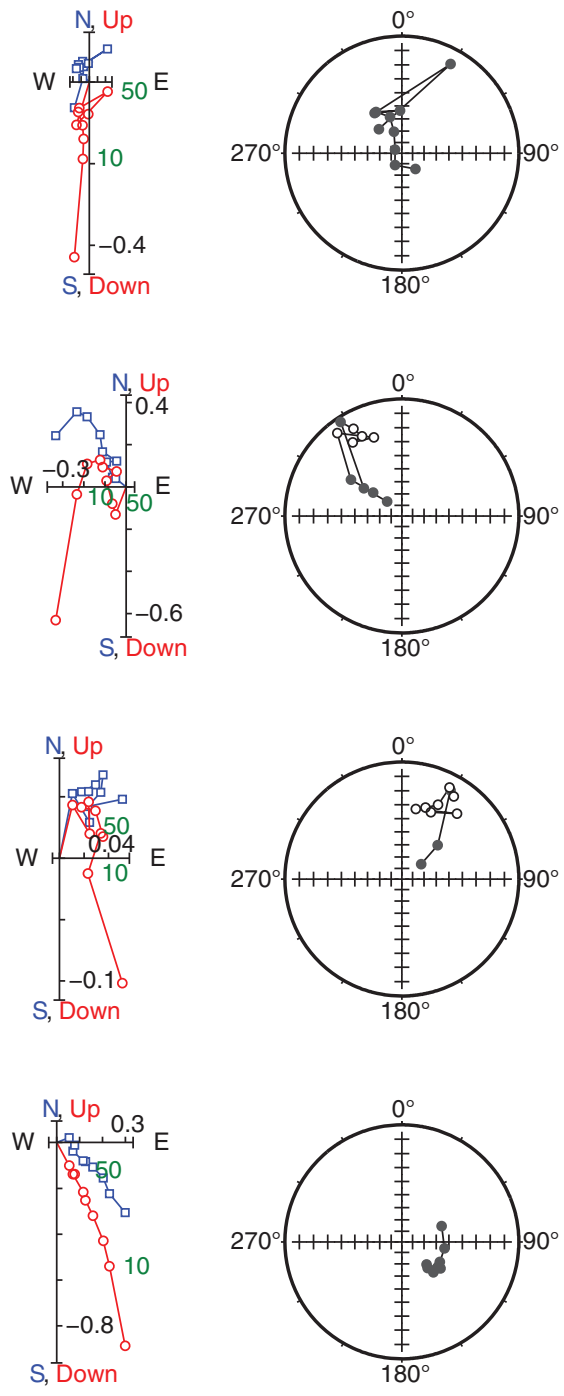

M 0.5 346-U1430A-13H-1W, 74-76 cm

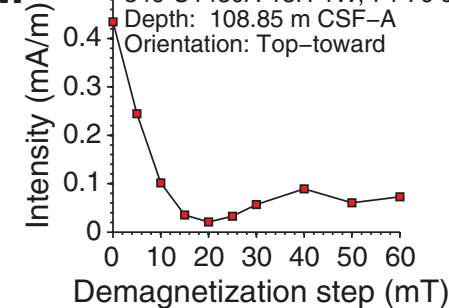

N 0.2 346-U1430A-14H-1W, $95-97 \mathrm{~cm}$ है Depth: $118.56 \mathrm{~m} \mathrm{CSF-A}$

0.15 Orientation: Top-toward

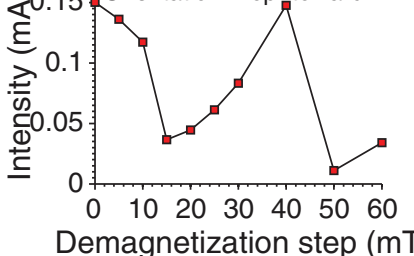

0

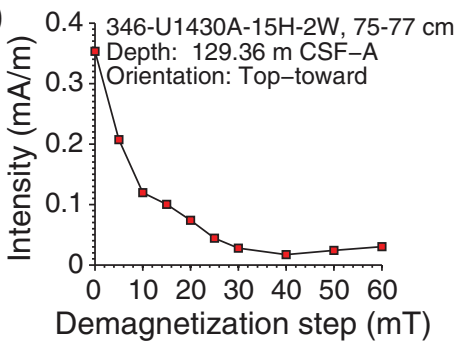

P 0.4 346-U1430A-16H-1W, 33-35 cm

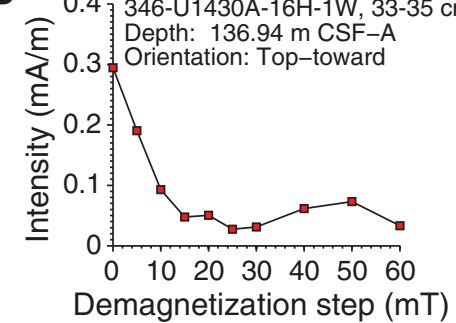

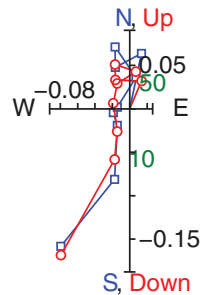
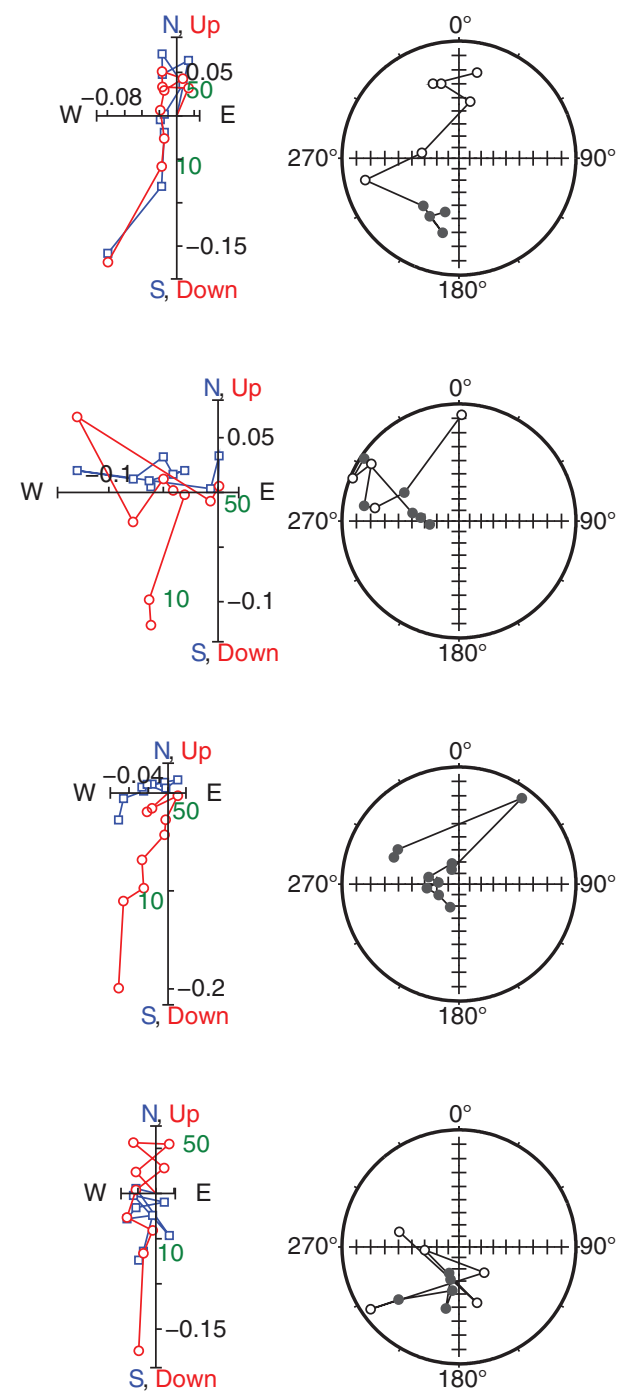
Figure F42 (continued). Q-X. 148.39-215.09 m CSF-A. (Continued on next page.)

$\mathbf{Q}_{\widehat{0}}$ 0.4 346-U1430A-17H-2W, 78-80 cm \& 0.3 Orientation: Top-toward

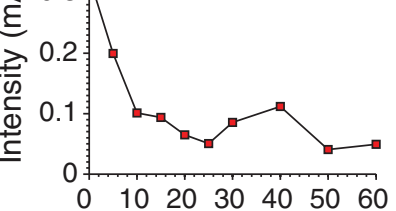

Demagnetization step $(\mathrm{mT})$

$\mathbf{R}^{0}$ 0.12 346-U1430A-18H-6W, 68-70 cm E 0.1 Orientation: Top-toward छ

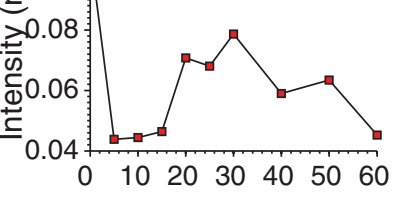

Demagnetization step (mT)

S 0.25 346-U1430A-19H-3W, $26-28 \mathrm{~cm}$

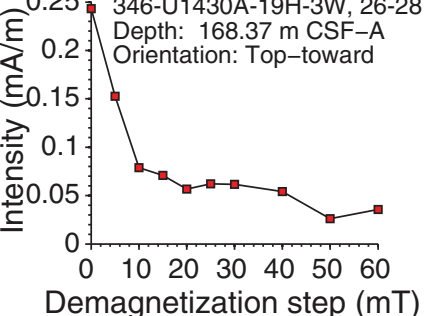

T 0.4 346-U1430A-20H-2W, 36-38 cm

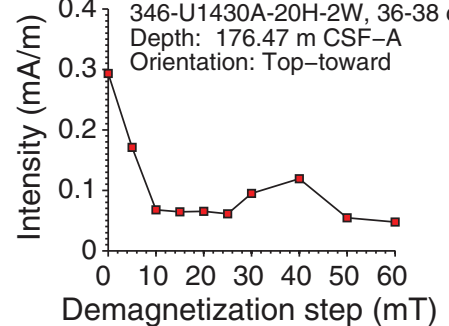

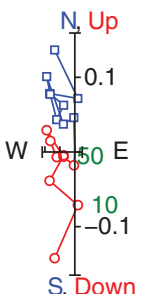
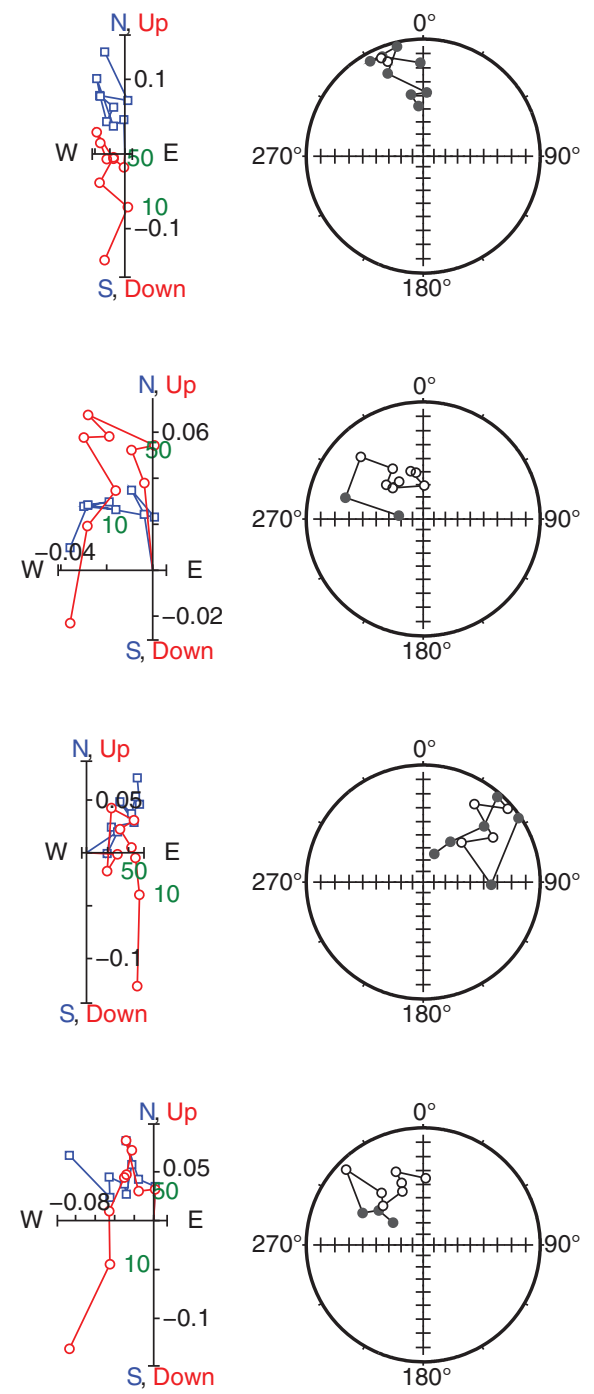

U 0.25 346-U1430A-21H-1W, 97-99 cm है 0.2 Depth: $184.48 \mathrm{~m} \mathrm{CSF}-\mathrm{A}$ E 0.15 0.15 迹 0.1 $\begin{array}{lllllll}0 & 10 & 20 & 30 & 40 & 50 & 60\end{array}$ Demagnetization step (mT)

V 0.14 346-U1430A-22H-6W, 70-72 cm
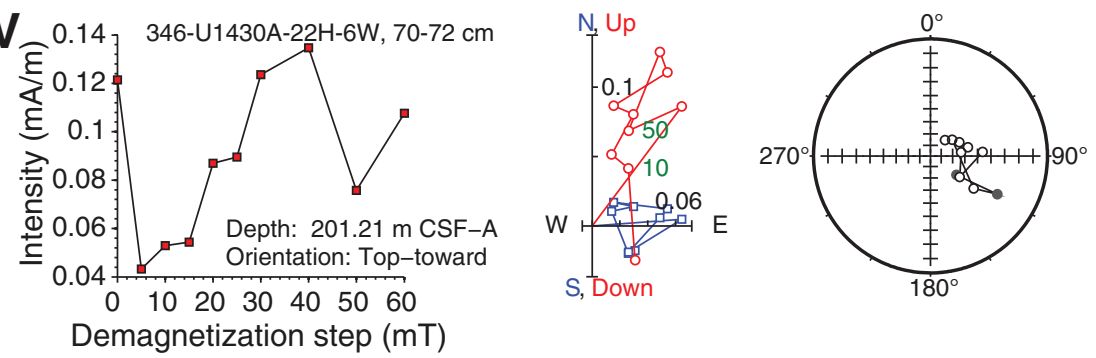

W 0.4 , 346-U1430A-23H-6W, $25-27 \mathrm{~cm}$
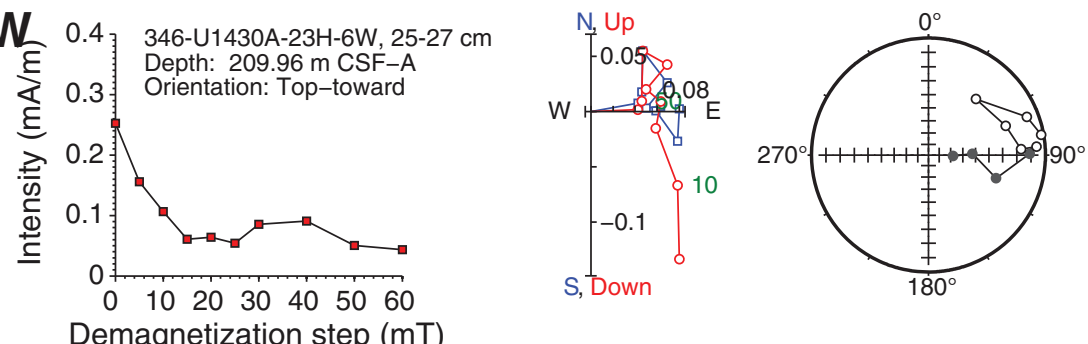
Demagnetization step (mT)

X 0.18 346-U1430A-24H-3W, 38-40 cm
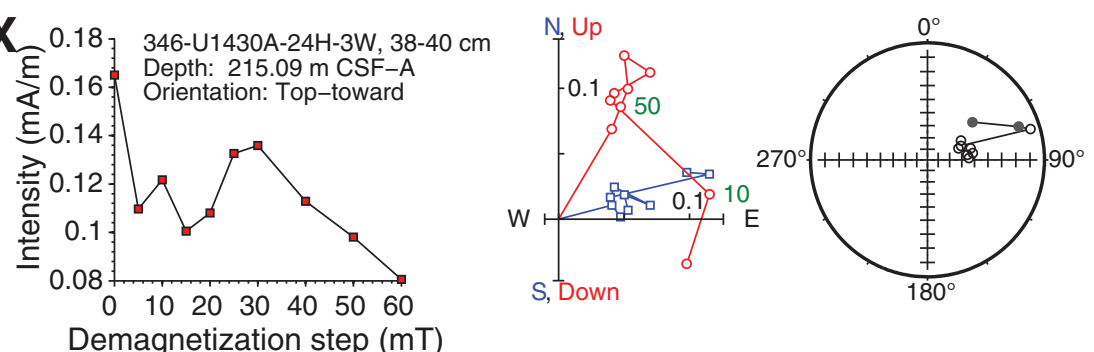
Figure F42 (continued). Y-BB. 221.91-264.87 m CSF-A.
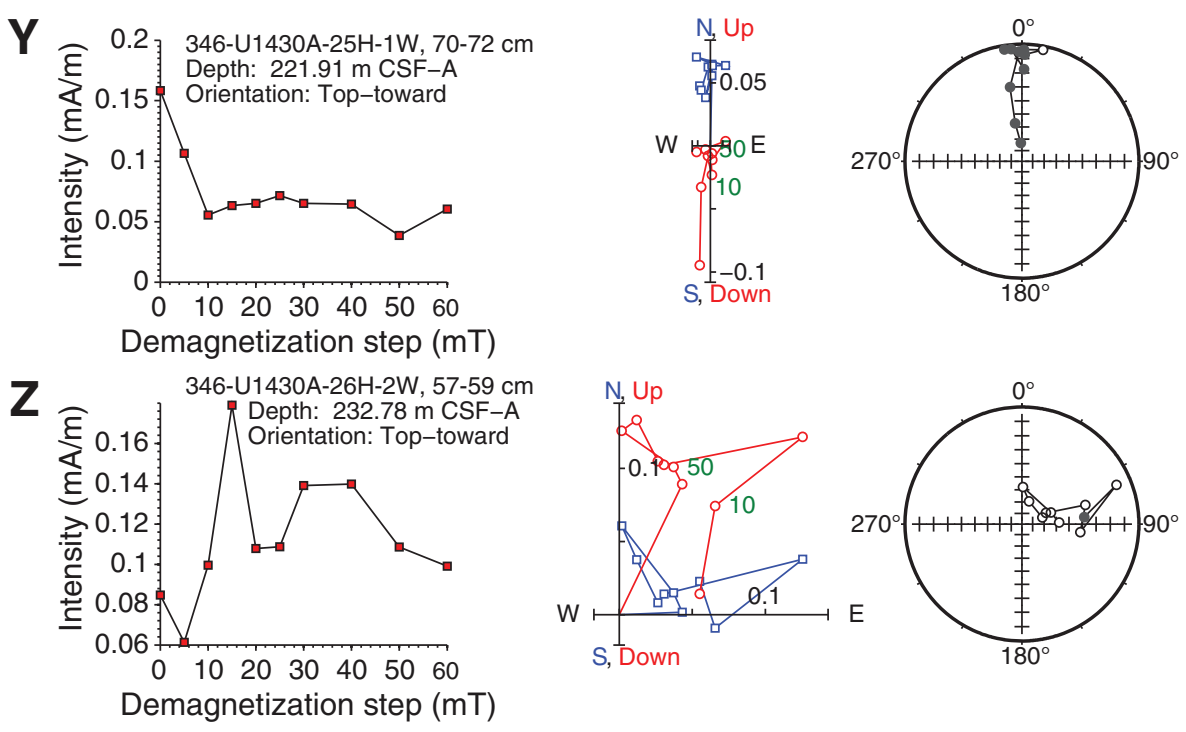

AA
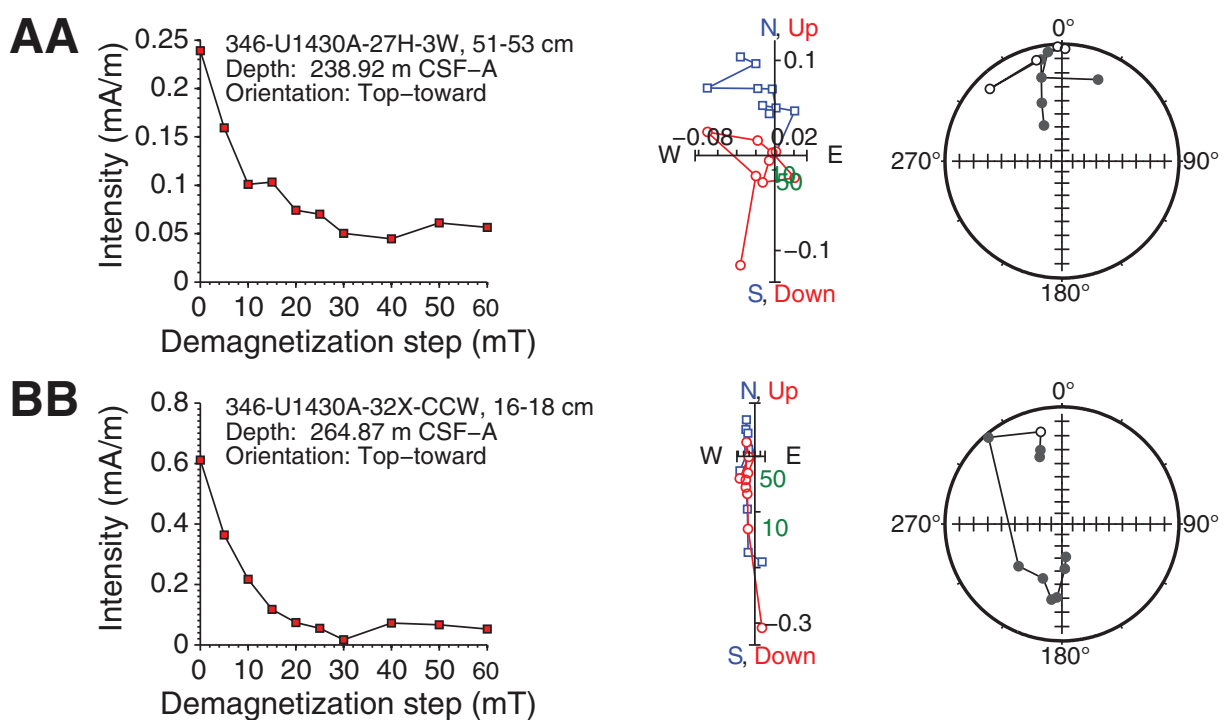
Figure F43. Suite of physical properties measured in Holes U1430A, U1430B, and U1430C. The first magnetic susceptibility panel shows WRMSL data of Hole U1430A, whereas the second panel shows point SHMSL susceptibility data of Hole U1430A. Gamma ray attenuation (GRA) bulk density is from Hole U1430A. Natural gamma radiation (NGR) is from Hole U1430A. $P$-wave velocity panel shows combined data from WRMSL of Holes U1430A, U1430B, and U1430C. Dashed horizontal lines = lithologic subunit boundaries, solid horizontal lines $=$ lithologic unit boundaries.

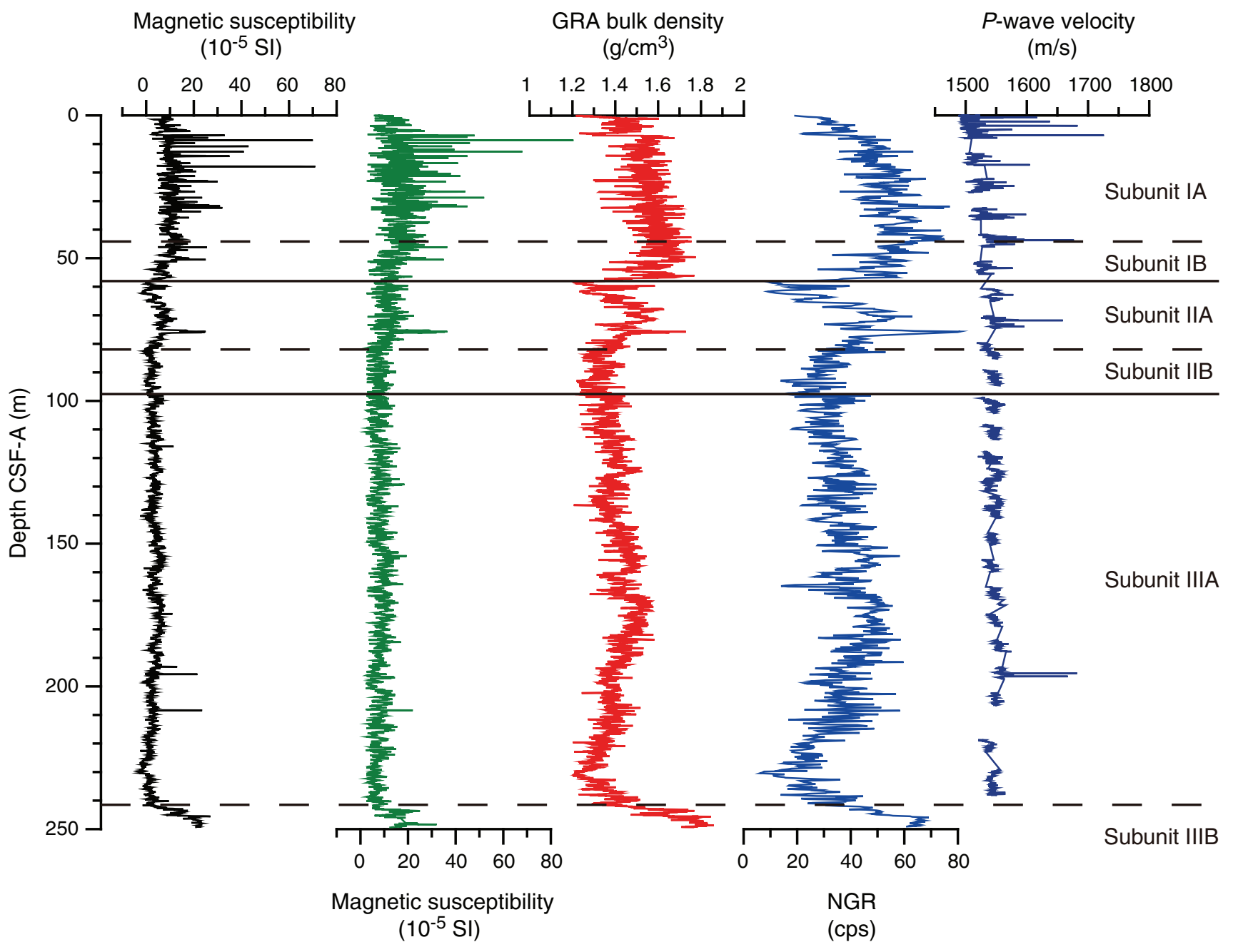


Figure F44. Data comparison and correlation of unit boundaries between Sites U1425 and U1430 in gamma ray attenuation (GRA) bulk density and natural gamma radiation (NGR).

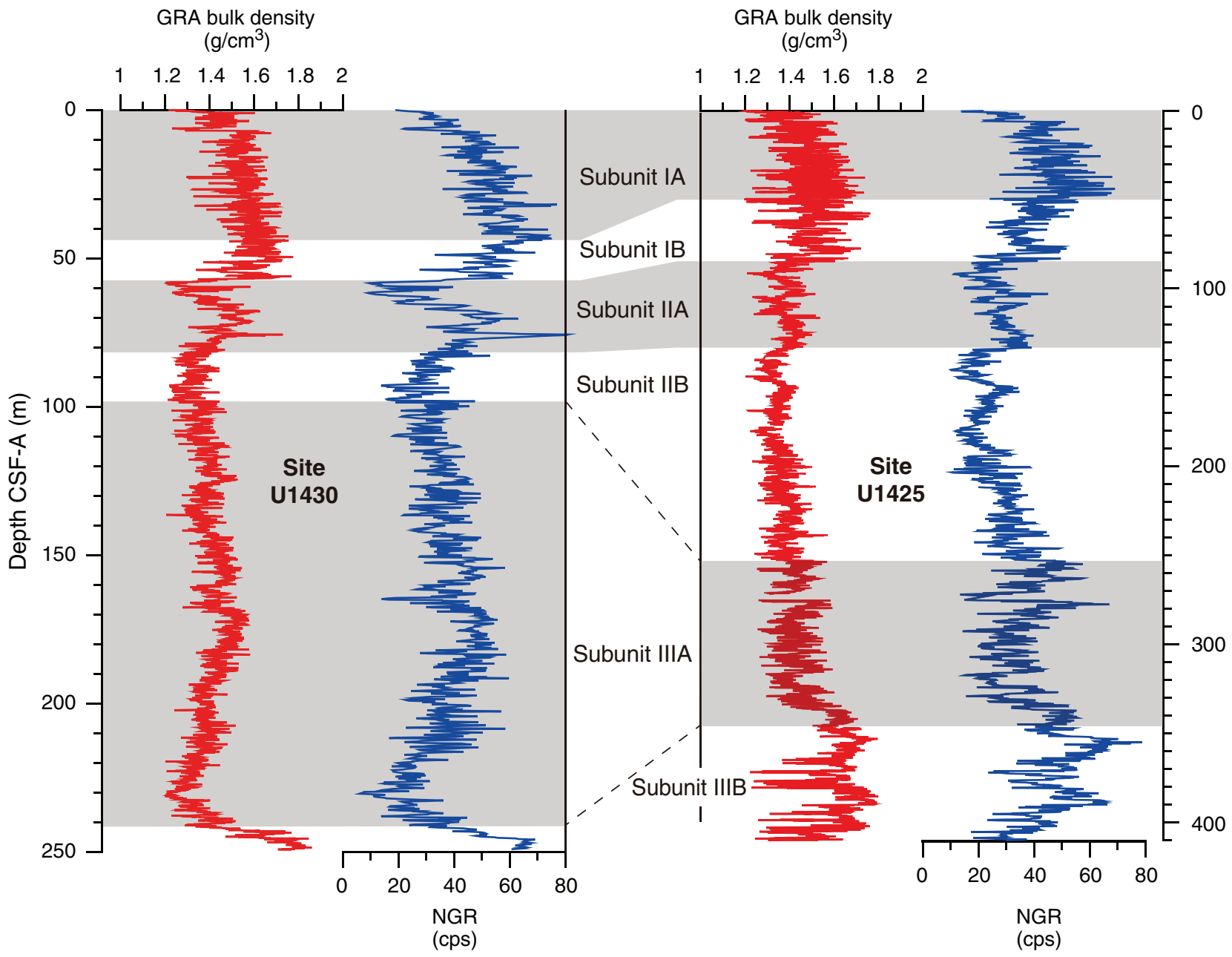


Figure F45. Discrete bulk density, grain density, porosity, water content, and shear strength, Site U1430. Dashed horizontal lines = lithologic subunit boundaries, solid horizontal lines = lithologic unit boundaries.

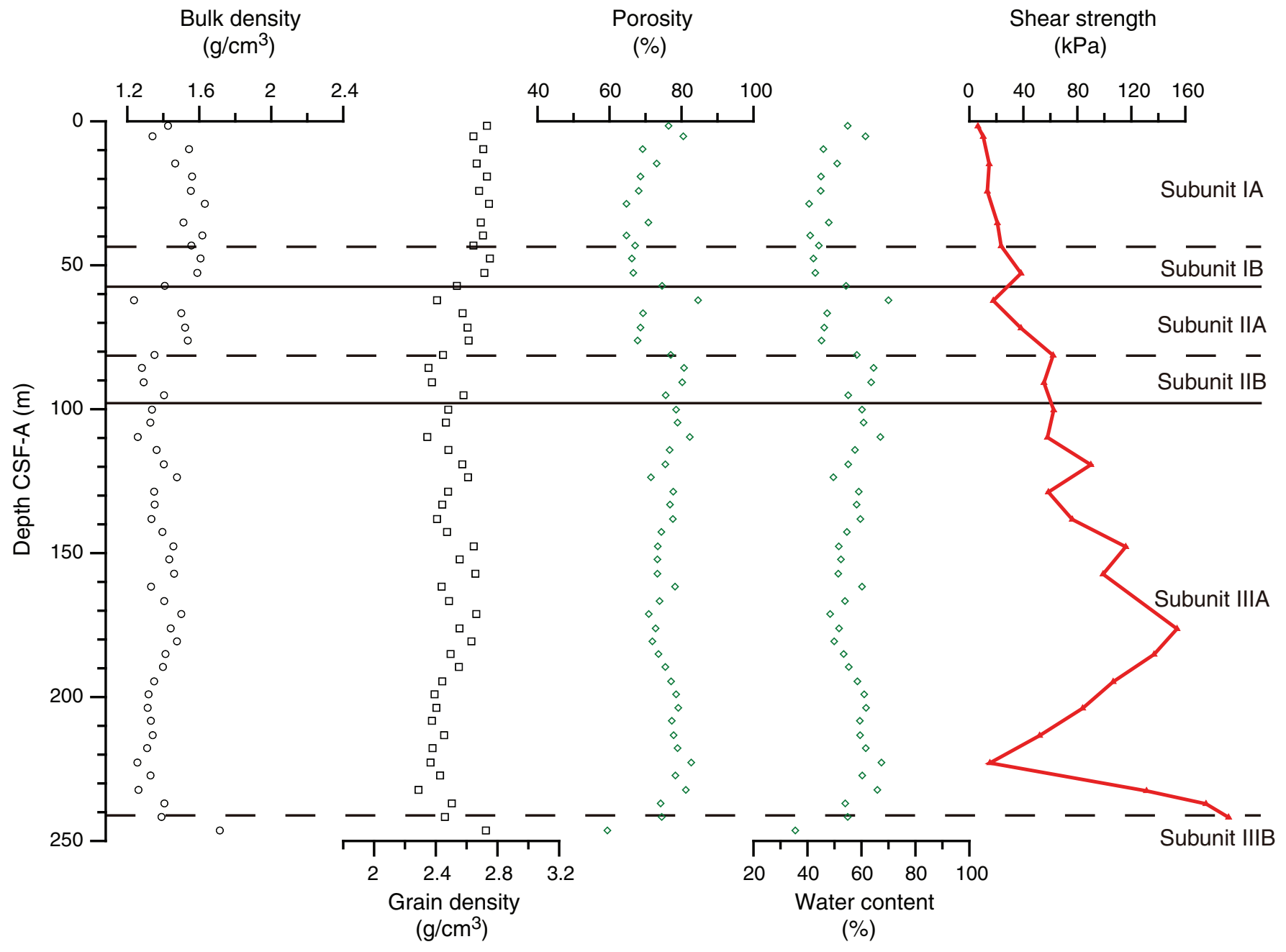


Figure F46. Color reflectance $\left(\mathrm{L}^{*}, \mathrm{a}^{*}\right.$, and $\left.\mathrm{b}^{*}\right)$, Hole U1430B. Dashed horizontal lines = lithologic subunit boundaries, solid horizontal lines $=$ lithologic unit boundaries.

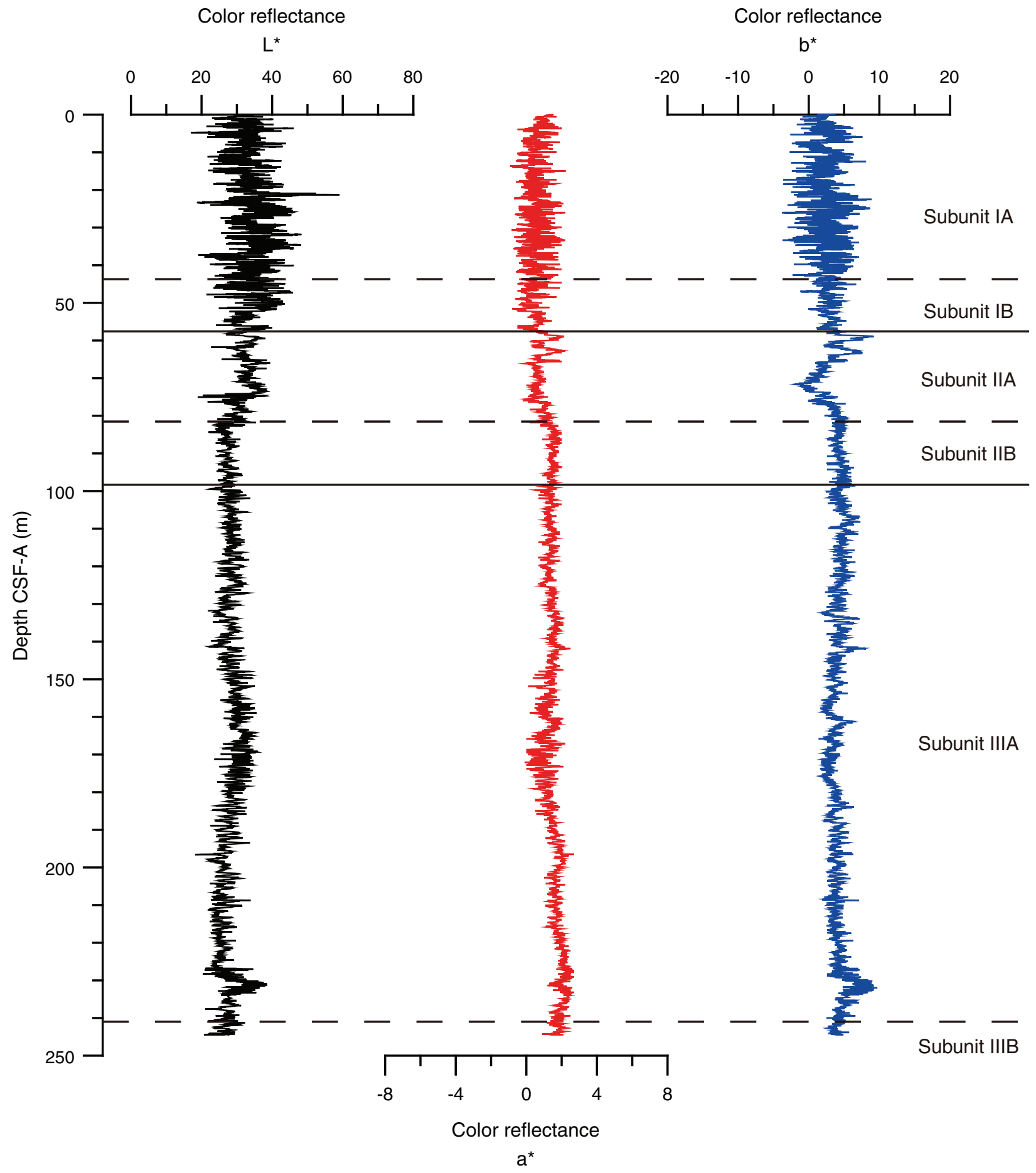


Figure F47. Diffuse reflectance data comparison between Sites U1425 and U1430 in $\mathrm{L}^{*}-\mathrm{a}^{*}$ and $\mathrm{a}^{*}-\mathrm{b}^{*}$ color spaces. Average $L^{*}$ for each site is depicted by lines in upper panels.
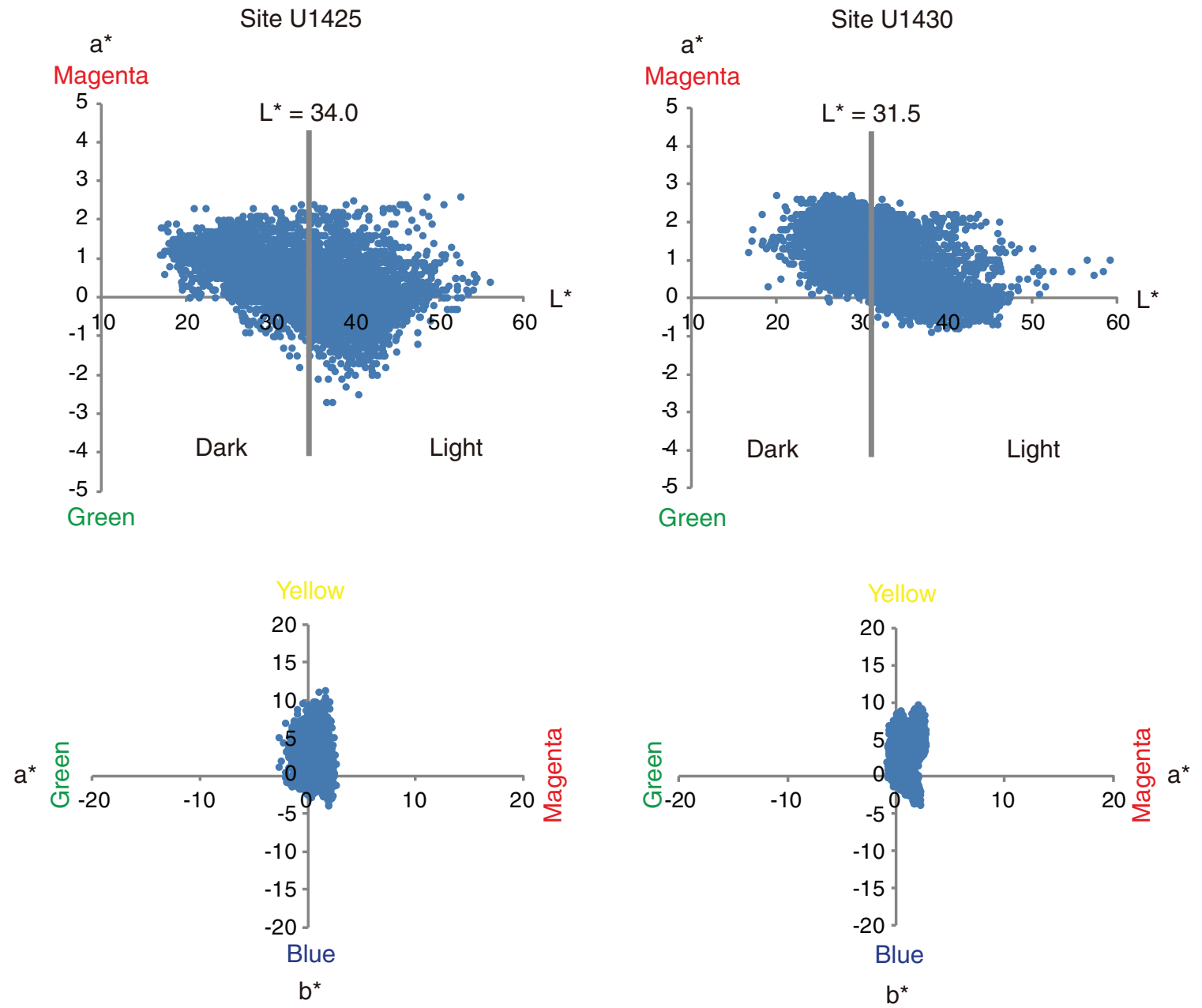
Figure F48. Logging operations summary diagram, Site U1430. FMS = Formation MicroScanner.

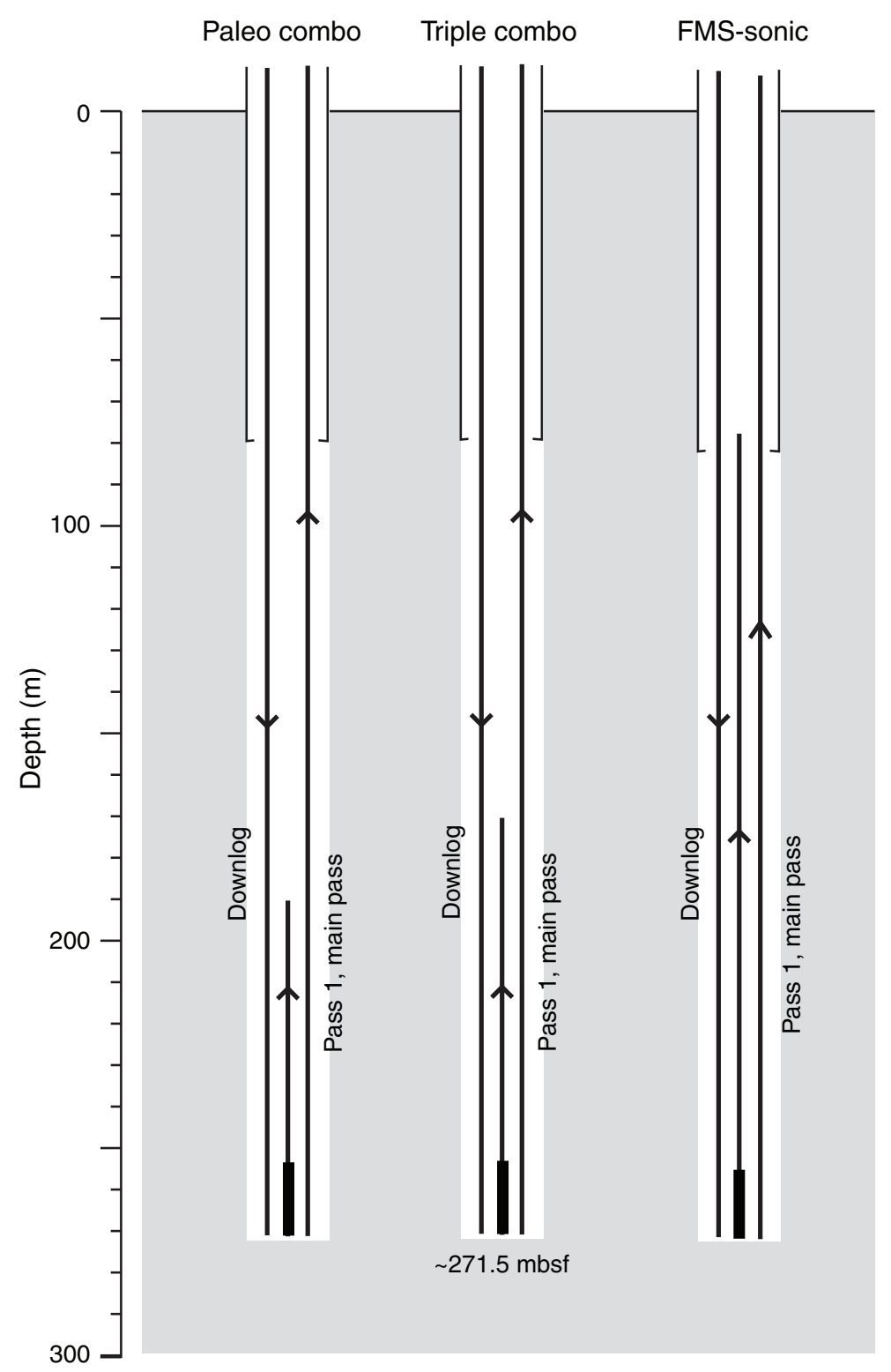


Figure F49. Downhole logs and logging units, Hole U1430B. HSGR = standard (total) gamma radiation, NGR = natural gamma radiation, RHOM = bulk density, RLA1 = shallow apparent resistivity, RT HRLT = "true" resistivity, MSS = Magnetic Susceptibility Sonde, LMSS = low-resolution MSS, HMSS = high-resolution MSS.

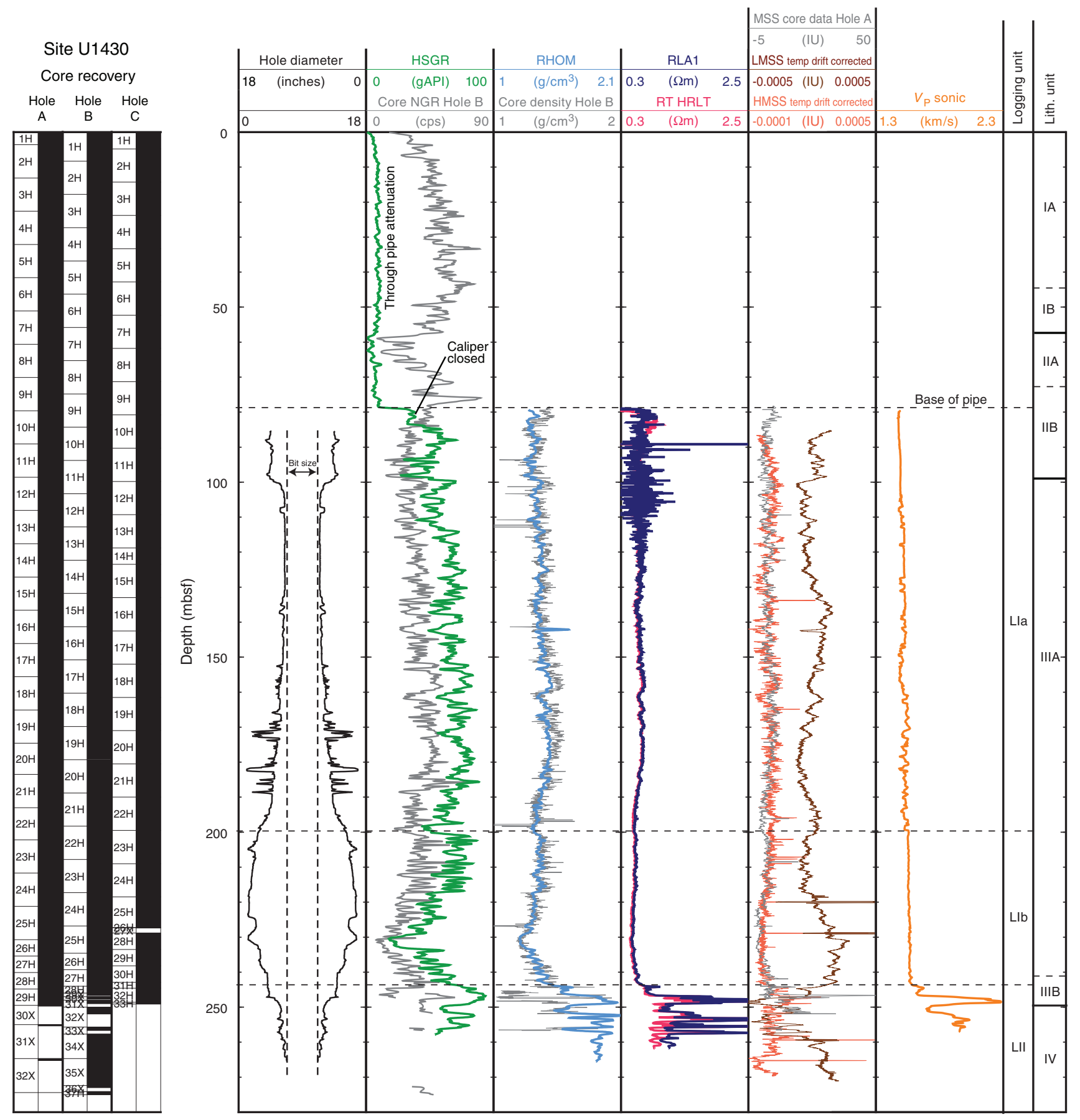


Figure F50. Natural gamma radiation logs, straight (nonoriented) Formation MicroScanner (FMS) images, and logging units, Hole U1430B. HSGR = standard (total) gamma radiation, HCGR = computed gamma radiation.

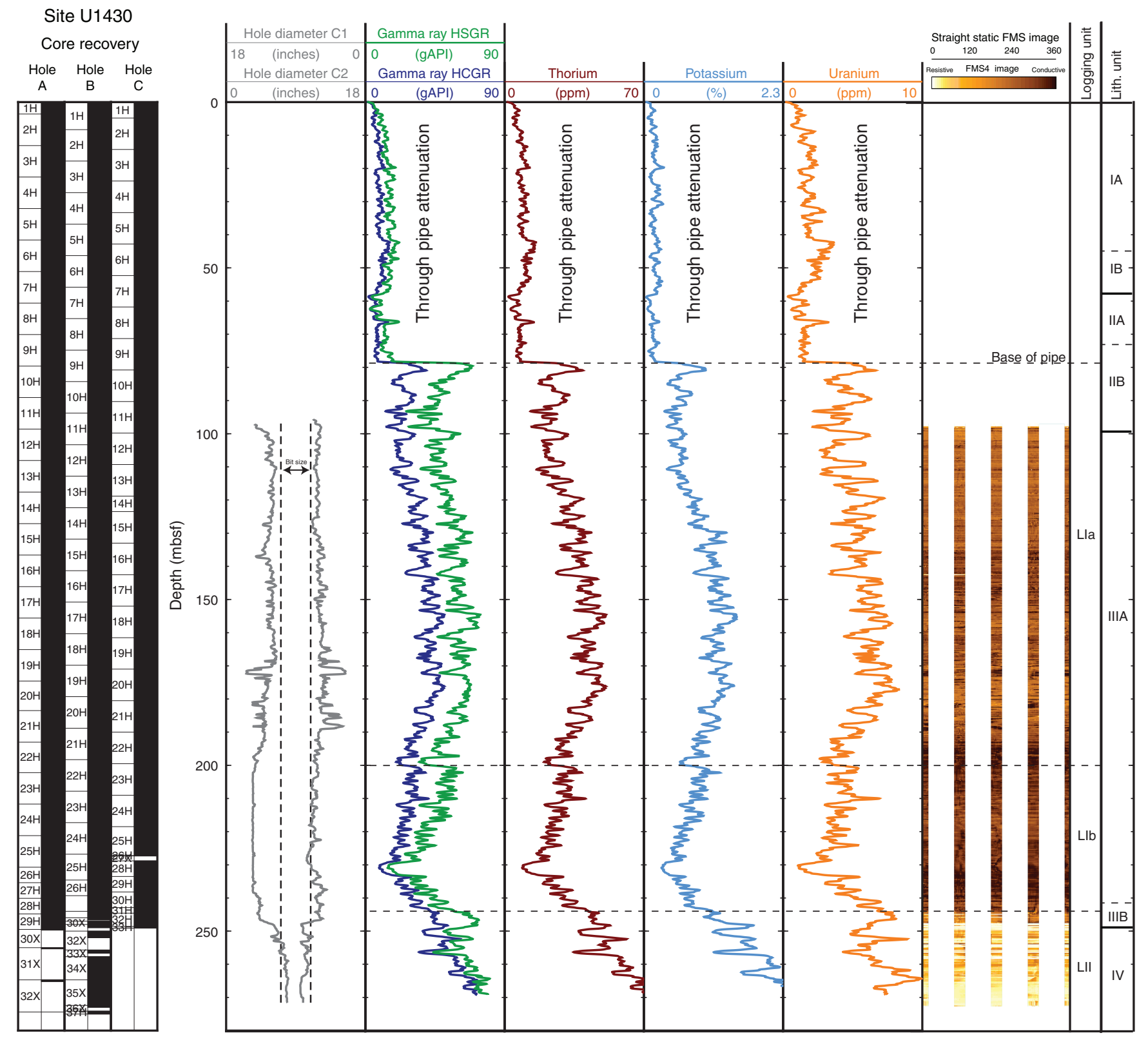


Figure F51. Correlation of downhole logs and straight (nonoriented) Formation MicroScanner (FMS) images (290-323 mbsf) in Hole U1430B, illustrating the cyclic nature of the sediment record at intervals of $\sim 8-15 \mathrm{~m}$. $\mathrm{NGR}=$ natural gamma radiation, $\mathrm{HSGR}=$ standard (total) natural gamma radiation, RT = "true" resistivity.

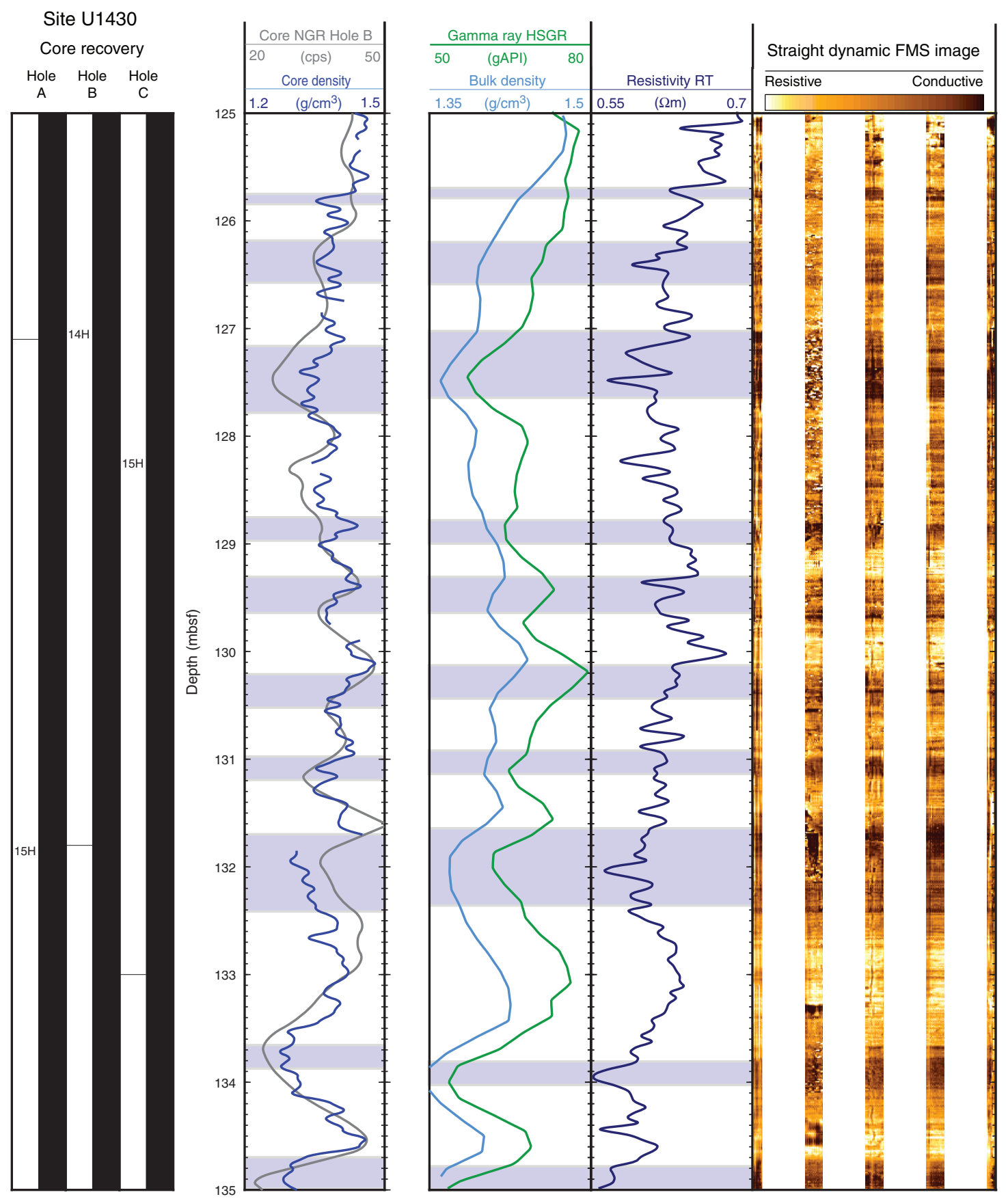


Figure F52. Plots of heat flow calculations, Hole U1430A. A. In situ sediment temperatures from advanced piston corer temperature tool (APCT-3) measurements with average values for mudline and Cores 346-U1430A$4 \mathrm{H}, 7 \mathrm{H}, 10 \mathrm{H}$, and $13 \mathrm{H}$ (circles), and linear fit. B. In situ thermal conductivity data (squares) with calculated thermal resistance (solid line). C. Bullard plot of heat flow calculated from a linear fit of temperature vs. thermal resistance data.
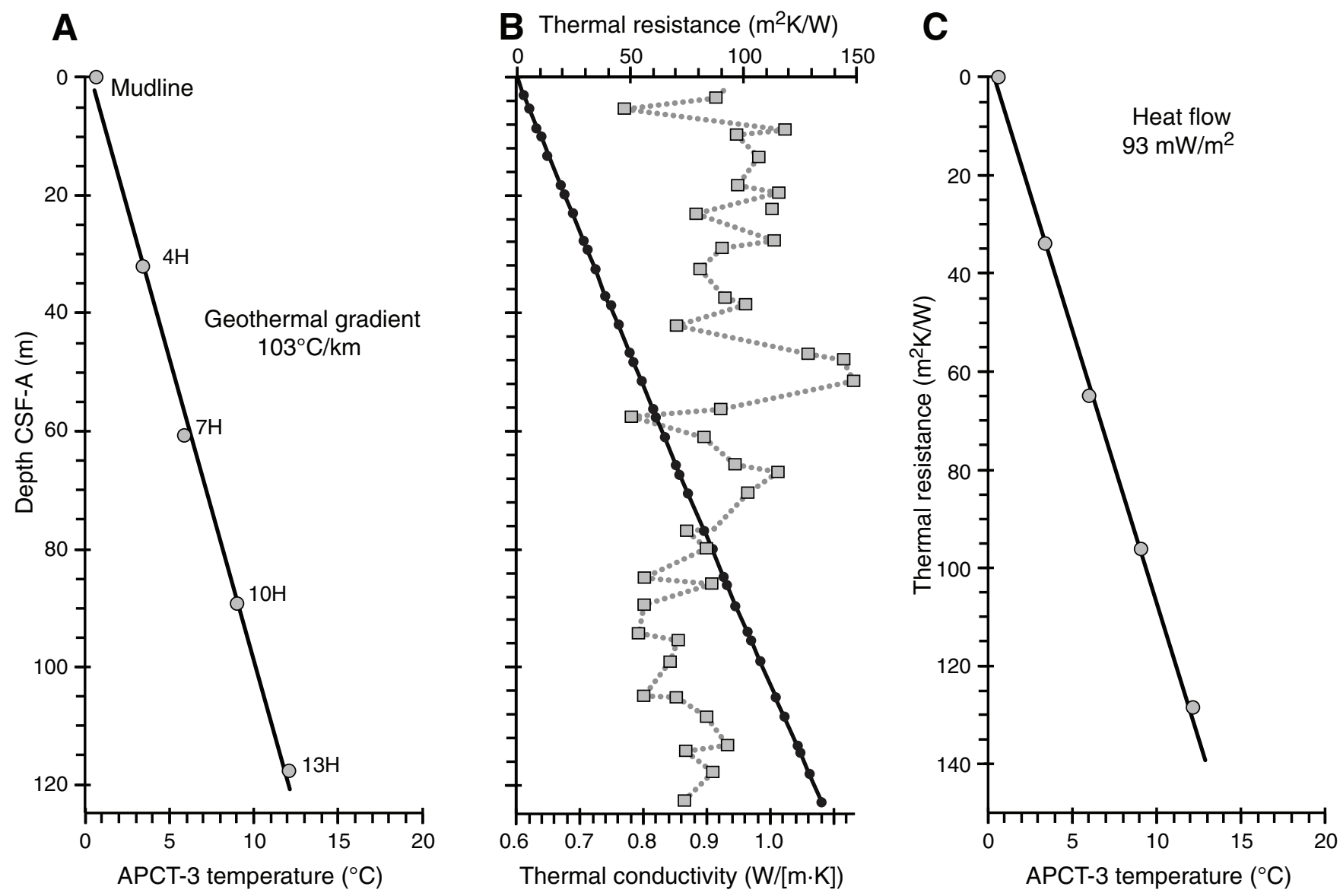
Figure F53. Composited cores and splice for Site U1430. Each core is adjusted (in depth) by a constant amount to align it with adjacent cores at a chosen tie point (typically a distinctive feature in all of the data sets). Other features may or may not align among adjacent cores because of differential squeezing and stretching during the coring process or because of variable expansion characteristics. The splice is constructed from the composited cores by selecting intervals from different holes such that coring gaps and drilling disturbances are avoided. Data included in the splice are plotted on the CCSF-D scale, whereas data not included in the splice are plotted on the CCSF-A scale. Horizontal light green lines indicate tie points where the splice changes from one hole to another. Only the splice is plotted on the correct $y$-axis scale; data from the Holes U1430A, $\mathrm{U} 1430 \mathrm{~B}$, and U1430C are offset by 40, 80, or 120 units, respectively, for illustrative purposes. One and two point spikes are artifacts generated when the track sensor measures beyond the end of the $\sim 150 \mathrm{~cm}$ sections. A. 0-100 m CCSF-A. (Continued on next two pages.)
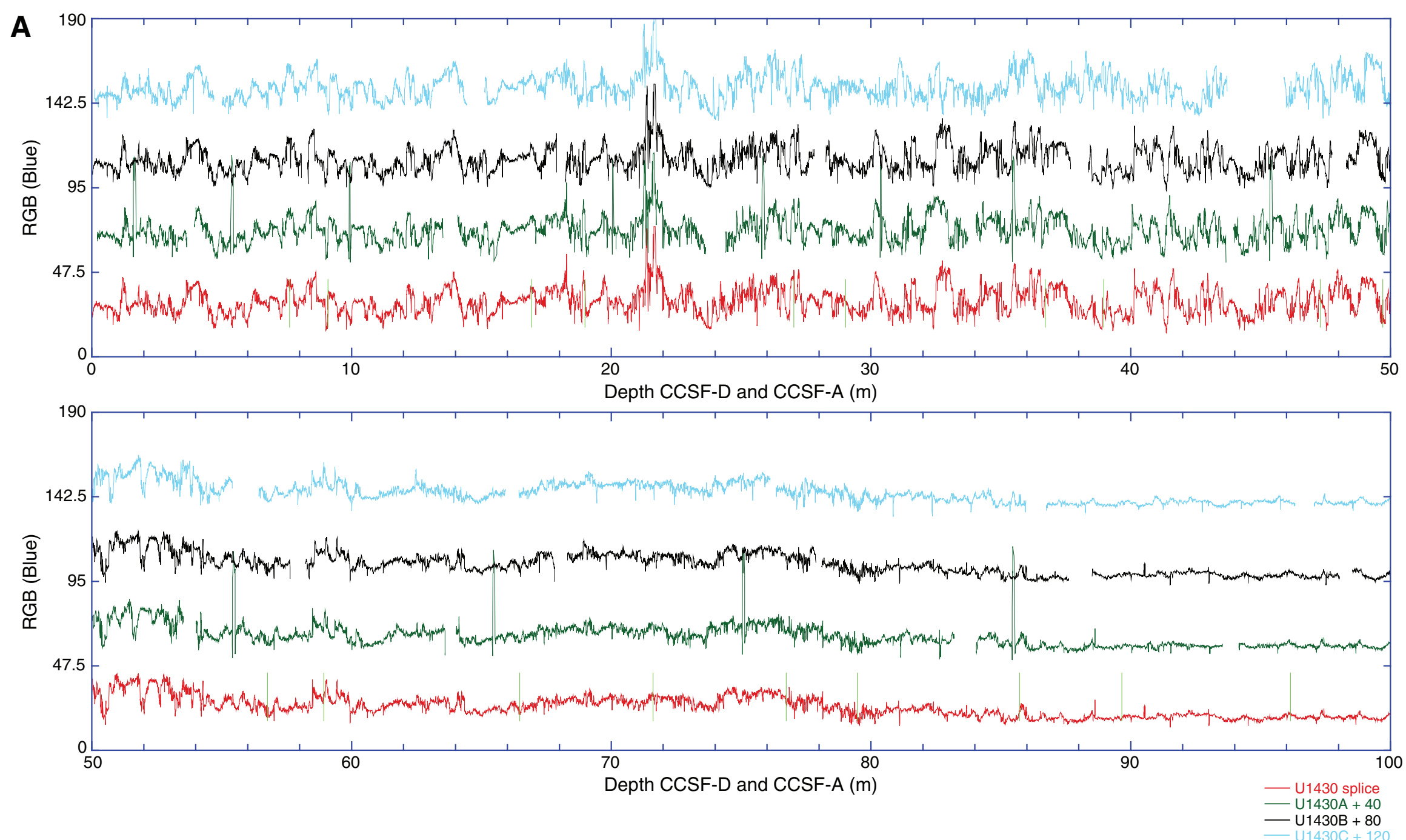
Figure F53 (continued). B. 100-200 m CCSF-A. (Continued on next page.)
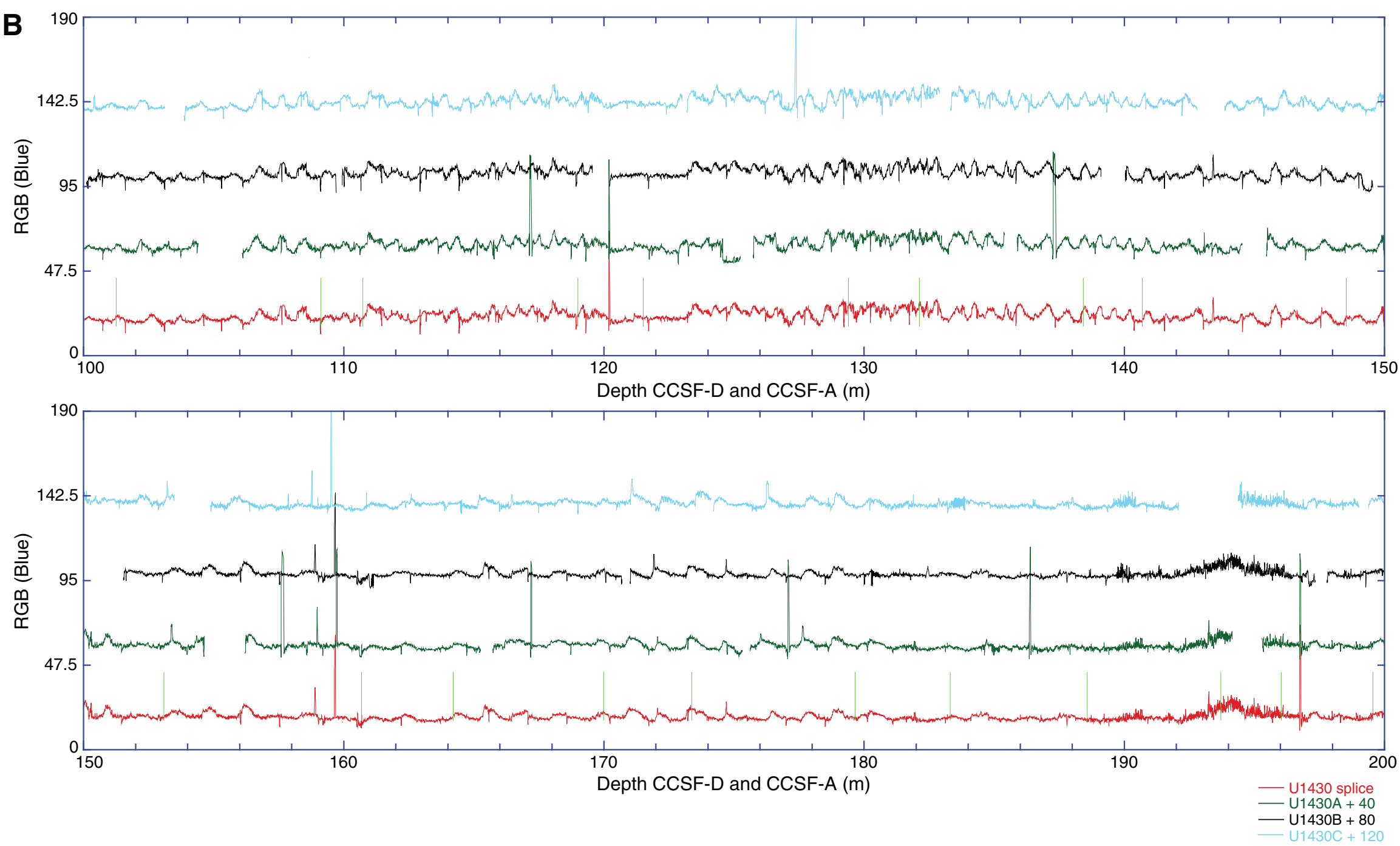
Figure F53 (continued). C. 200-270 m CCSF-A.
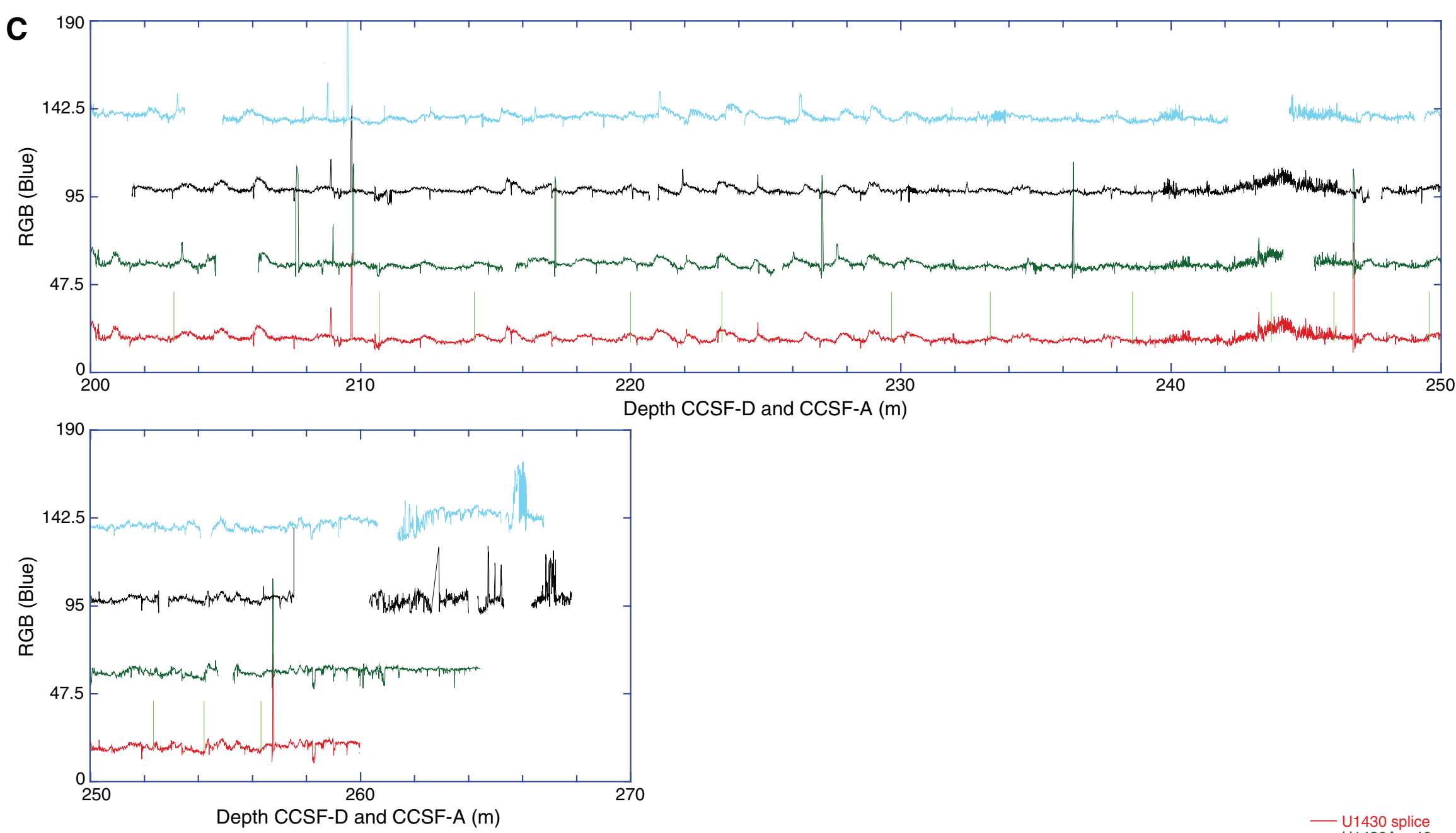
Figure F54. Age model and sedimentation rates, Site U1430. A. Synthesis of biostratigraphic and paleomagnetic age control points with most likely depth-age relationship lines used to establish a preliminary age model. B. Average sedimentation rates between age control points plotted with gamma ray attenuation (GRA) density.

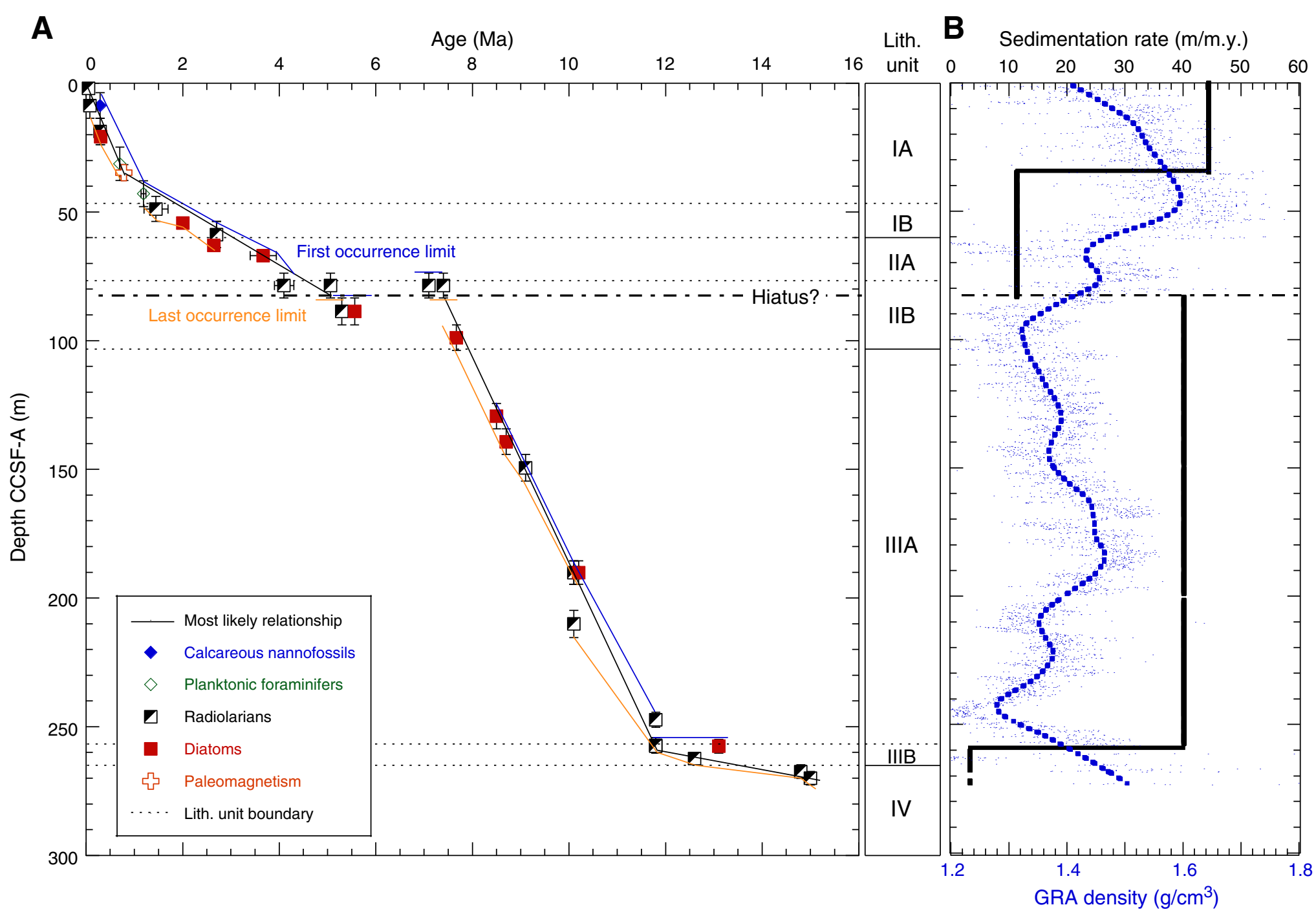


Table T1. Hole summary, Site U1430. (Continued on next two pages.)

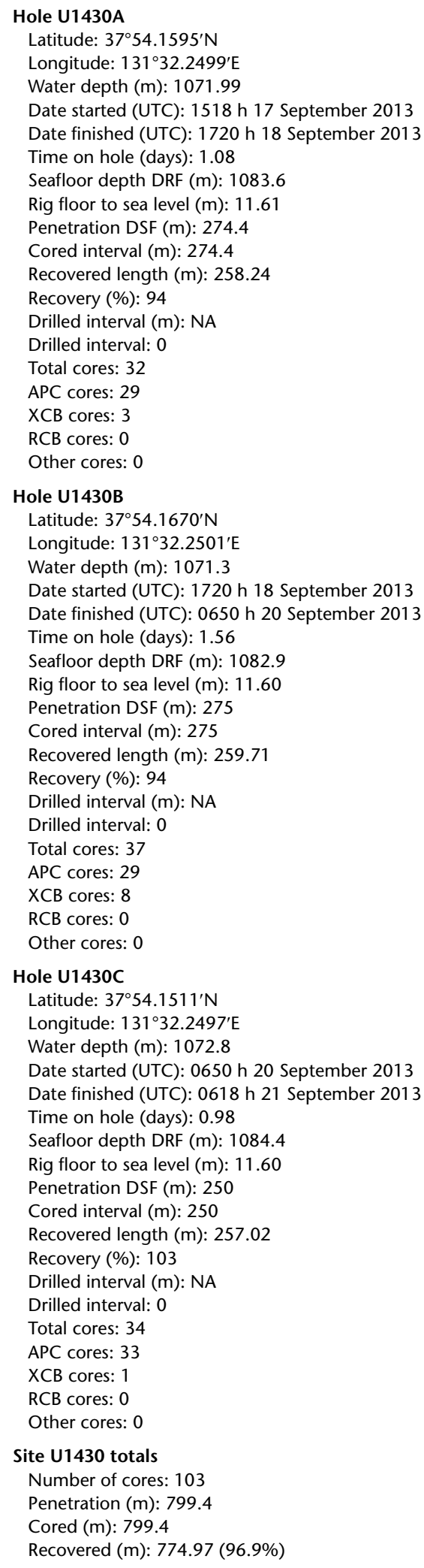


Table T1 (continued). (Continued on next page.)

\begin{tabular}{|c|c|c|c|c|c|c|c|c|c|c|}
\hline Core & $\begin{array}{c}\text { Date } \\
\text { (Aug 2013) }\end{array}$ & $\begin{array}{c}\text { Time } \\
\text { (h) }\end{array}$ & $\begin{array}{l}\text { Top depth } \\
\text { of cored } \\
\text { interval } \\
\text { DSF }(m)\end{array}$ & $\begin{array}{l}\text { Bottom depth } \\
\text { of cored } \\
\text { interval } \\
\text { DSF }(m)\end{array}$ & $\begin{array}{l}\text { Interval } \\
\text { advanced } \\
(\mathrm{m})\end{array}$ & $\begin{array}{l}\text { Top depth } \\
\text { of recovered } \\
\text { core } \\
\text { CSF }(m)\end{array}$ & $\begin{array}{c}\text { Bottom depth } \\
\text { of recovered } \\
\text { core } \\
\text { CSF }(m)\end{array}$ & $\begin{array}{l}\text { Length of } \\
\text { core } \\
\text { recovered } \\
\text { (m) }\end{array}$ & $\begin{array}{l}\text { Curated } \\
\text { length } \\
(\mathrm{m})\end{array}$ & $\begin{array}{c}\text { Recovery } \\
\text { (\%) }\end{array}$ \\
\hline \multicolumn{11}{|c|}{ 346-U1430A- } \\
\hline $1 \mathrm{H}$ & 16 & 1950 & 0.0 & 3.6 & 3.6 & 0.0 & 3.58 & 3.58 & 3.58 & 99 \\
\hline $2 \mathrm{H}$ & 16 & 2040 & 3.6 & 13.1 & 9.5 & 3.6 & 13.33 & 9.73 & 9.73 & 102 \\
\hline $3 \mathrm{H}$ & 16 & 2110 & 13.1 & 22.6 & 9.5 & 13.1 & 22.93 & 9.83 & 9.83 & 103 \\
\hline $4 \mathrm{H}$ & 16 & 2150 & 22.6 & 32.1 & 9.5 & 22.6 & 32.22 & 9.62 & 9.62 & 101 \\
\hline $5 \mathrm{H}$ & 16 & 2220 & 32.1 & 41.6 & 9.5 & 32.1 & 42.10 & 10.00 & 10.00 & 105 \\
\hline $6 \mathrm{H}$ & 16 & 2245 & 41.6 & 51.1 & 9.5 & 41.6 & 51.42 & 9.82 & 9.82 & 103 \\
\hline $7 \mathrm{H}$ & 16 & 2325 & 51.1 & 60.6 & 9.5 & 51.1 & 61.05 & 9.95 & 9.95 & 105 \\
\hline $8 \mathrm{H}$ & 16 & 2350 & 60.6 & 70.1 & 9.5 & 60.6 & 70.53 & 9.93 & 9.93 & 105 \\
\hline $9 \mathrm{H}$ & 17 & 0020 & 70.1 & 79.6 & 9.5 & 70.1 & 79.95 & 9.85 & 9.85 & 104 \\
\hline $10 \mathrm{H}$ & 17 & 0105 & 79.6 & 89.1 & 9.5 & 79.6 & 89.51 & 9.91 & 9.91 & 104 \\
\hline $11 \mathrm{H}$ & 17 & 0130 & 89.1 & 98.6 & 9.5 & 89.1 & 98.89 & 9.79 & 9.79 & 103 \\
\hline $12 \mathrm{H}$ & 17 & 0200 & 98.6 & 108.1 & 9.5 & 98.6 & 108.46 & 9.86 & 9.86 & 104 \\
\hline $13 \mathrm{H}$ & 17 & 0240 & 108.1 & 117.6 & 9.5 & 108.1 & 117.98 & 9.88 & 9.88 & 104 \\
\hline $14 \mathrm{H}$ & 17 & 0310 & 117.6 & 127.1 & 9.5 & 117.6 & 127.47 & 9.87 & 9.87 & 104 \\
\hline $15 \mathrm{H}$ & 17 & 0340 & 127.1 & 136.6 & 9.5 & 127.1 & 136.96 & 9.86 & 9.86 & 104 \\
\hline $16 \mathrm{H}$ & 17 & 0405 & 136.6 & 146.1 & 9.5 & 136.6 & 146.52 & 9.92 & 9.92 & 104 \\
\hline $17 \mathrm{H}$ & 17 & 0435 & 146.1 & 155.6 & 9.5 & 146.1 & 156.01 & 9.91 & 9.91 & 104 \\
\hline $18 \mathrm{H}$ & 17 & 0500 & 155.6 & 165.1 & 9.5 & 155.6 & 165.15 & 9.55 & 9.55 & 101 \\
\hline $19 \mathrm{H}$ & 17 & 0525 & 165.1 & 174.6 & 9.5 & 165.1 & 175.01 & 9.91 & 9.91 & 104 \\
\hline $20 \mathrm{H}$ & 17 & 0555 & 174.6 & 183.5 & 8.9 & 174.6 & 183.53 & 8.93 & 8.93 & 100 \\
\hline $21 \mathrm{H}$ & 17 & 0635 & 183.5 & 193.0 & 9.5 & 183.5 & 192.95 & 9.45 & 9.45 & 99 \\
\hline $22 \mathrm{H}$ & 17 & 0710 & 193.0 & 202.2 & 9.2 & 193.0 & 202.25 & 9.25 & 9.25 & 101 \\
\hline $23 \mathrm{H}$ & 17 & 0740 & 202.2 & 211.7 & 9.5 & 202.2 & 211.86 & 9.66 & 9.66 & 102 \\
\hline $24 \mathrm{H}$ & 17 & 0815 & 211.7 & 221.2 & 9.5 & 211.7 & 221.48 & 9.78 & 9.78 & 103 \\
\hline $25 \mathrm{H}$ & 17 & 0910 & 221.2 & 230.7 & 9.5 & 221.2 & 230.70 & 9.50 & 9.50 & 100 \\
\hline $26 \mathrm{H}$ & 17 & 0950 & 230.7 & 235.4 & 4.7 & 230.7 & 235.69 & 4.99 & 4.99 & 106 \\
\hline $27 \mathrm{H}$ & 17 & 1020 & 235.4 & 240.1 & 4.7 & 235.4 & 240.43 & 5.03 & 5.03 & 107 \\
\hline $28 \mathrm{H}$ & 17 & 1045 & 240.1 & 244.8 & 4.7 & 240.1 & 245.11 & 5.01 & 5.01 & 107 \\
\hline $29 \mathrm{H}$ & 17 & 1120 & 244.8 & 249.5 & 4.7 & 244.8 & 249.55 & 4.75 & 4.75 & 101 \\
\hline $30 x$ & 17 & 1320 & 249.5 & 255.0 & 5.5 & 249.5 & 249.73 & 0.23 & 0.23 & 4 \\
\hline $31 x$ & 17 & 1415 & 255.0 & 264.7 & 9.7 & 255.0 & 255.34 & 0.34 & 0.34 & 4 \\
\hline \multirow[t]{2}{*}{$32 x$} & 17 & 1505 & 264.7 & 274.4 & 9.7 & 264.7 & 265.25 & 0.55 & 0.55 & 6 \\
\hline & & & \multicolumn{2}{|c|}{ Total advanced $(\mathrm{m})$} & 274.4 & \multicolumn{2}{|c|}{ Total recovered $(\mathrm{m})$ : } & 258.24 & & \\
\hline \multicolumn{11}{|c|}{ 346-U1430B- } \\
\hline $1 \mathrm{H}$ & 17 & 1840 & 0.0 & 8.3 & 8.3 & 0.0 & 8.27 & 8.27 & 8.27 & 100 \\
\hline $2 \mathrm{H}$ & 17 & 1905 & 8.3 & 17.8 & 9.5 & 8.3 & 18.03 & 9.73 & 9.73 & 102 \\
\hline $3 \mathrm{H}$ & 17 & 1930 & 17.8 & 27.3 & 9.5 & 17.8 & 27.58 & 9.78 & 9.78 & 103 \\
\hline $4 \mathrm{H}$ & 17 & 1955 & 27.3 & 36.8 & 9.5 & 27.3 & 36.94 & 9.64 & 9.64 & 101 \\
\hline $5 \mathrm{H}$ & 17 & 2020 & 36.8 & 46.3 & 9.5 & 36.8 & 46.37 & 9.57 & 9.57 & 101 \\
\hline $6 \mathrm{H}$ & 17 & 2055 & 46.3 & 55.8 & 9.5 & 46.3 & 55.87 & 9.57 & 9.57 & 101 \\
\hline $7 \mathrm{H}$ & 17 & 2120 & 55.8 & 65.3 & 9.5 & 55.8 & 65.56 & 9.76 & 9.76 & 103 \\
\hline $8 \mathrm{H}$ & 17 & 2145 & 65.3 & 74.8 & 9.5 & 65.3 & 75.12 & 9.82 & 9.82 & 103 \\
\hline $9 \mathrm{H}$ & 17 & 2210 & 74.8 & 84.3 & 9.5 & 74.8 & 84.60 & 9.80 & 9.80 & 103 \\
\hline $10 \mathrm{H}$ & 17 & 2310 & 84.3 & 93.8 & 9.5 & 84.3 & 93.86 & 9.56 & 9.56 & 101 \\
\hline $11 \mathrm{H}$ & 17 & 2335 & 93.8 & 103.3 & 9.5 & 93.8 & 103.61 & 9.81 & 9.81 & 103 \\
\hline $12 \mathrm{H}$ & 18 & 0000 & 103.3 & 112.8 & 9.5 & 103.3 & 113.13 & 9.83 & 9.83 & 103 \\
\hline $13 \mathrm{H}$ & 18 & 0030 & 112.8 & 122.3 & 9.5 & 112.8 & 122.69 & 9.89 & 9.89 & 104 \\
\hline $14 \mathrm{H}$ & 18 & 0055 & 122.3 & 131.8 & 9.5 & 122.3 & 131.94 & 9.64 & 9.64 & 101 \\
\hline $15 \mathrm{H}$ & 18 & 0120 & 131.8 & 141.3 & 9.5 & 131.8 & 141.44 & 9.64 & 9.64 & 101 \\
\hline $16 \mathrm{H}$ & 18 & 0145 & 141.3 & 150.8 & 9.5 & 141.3 & 150.98 & 9.68 & 9.68 & 102 \\
\hline $17 \mathrm{H}$ & 18 & 0210 & 150.8 & 160.3 & 9.5 & 150.8 & 160.70 & 9.90 & 9.90 & 104 \\
\hline $18 \mathrm{H}$ & 18 & 0235 & 160.3 & 169.8 & 9.5 & 160.3 & 170.04 & 9.74 & 9.74 & 103 \\
\hline $19 \mathrm{H}$ & 18 & 0300 & 169.8 & 179.3 & 9.5 & 169.8 & 179.08 & 9.28 & 9.28 & 98 \\
\hline $20 \mathrm{H}$ & 18 & 0325 & 179.3 & 188.8 & 9.5 & 179.3 & 188.92 & 9.62 & 9.62 & 101 \\
\hline $21 \mathrm{H}$ & 18 & 0350 & 188.8 & 198.3 & 9.5 & 188.8 & 198.43 & 9.63 & 9.63 & 101 \\
\hline $22 \mathrm{H}$ & 18 & 0415 & 198.3 & 207.8 & 9.5 & 198.3 & 208.00 & 9.70 & 9.70 & 102 \\
\hline $23 \mathrm{H}$ & 18 & 0440 & 207.8 & 217.3 & 9.5 & 207.8 & 217.52 & 9.72 & 9.72 & 102 \\
\hline $24 \mathrm{H}$ & 18 & 0505 & 217.3 & 226.8 & 9.5 & 217.3 & 227.01 & 9.71 & 9.71 & 102 \\
\hline $25 \mathrm{H}$ & 18 & 0545 & 226.8 & 234.6 & 7.8 & 226.8 & 234.60 & 7.80 & 7.80 & 100 \\
\hline $26 \mathrm{H}$ & 18 & 0630 & 234.6 & 239.3 & 4.7 & 234.6 & 239.56 & 4.96 & 4.96 & 106 \\
\hline $27 \mathrm{H}$ & 18 & 0705 & 239.3 & 244.0 & 4.7 & 239.3 & 244.42 & 5.12 & 5.12 & 109 \\
\hline $28 \mathrm{H}$ & 18 & 0730 & 244.0 & 246.0 & 2.0 & 244.0 & 247.68 & 3.68 & 3.68 & 184 \\
\hline $29 X$ & 18 & 0920 & 246.0 & 247.0 & 1.0 & 246.0 & 246.70 & 0.70 & 0.70 & 70 \\
\hline $30 x$ & 18 & 1010 & 247.0 & 248.0 & 1.0 & 247.0 & 247.69 & 0.69 & 0.69 & 69 \\
\hline $31 X$ & 18 & 1045 & 248.0 & 250.0 & 2.0 & 248.0 & 248.99 & 0.99 & 0.99 & 50 \\
\hline $32 X$ & 18 & 1135 & 250.0 & 255.7 & 5.7 & 250.0 & 251.96 & 1.96 & 1.96 & 34 \\
\hline
\end{tabular}


Table T1 (continued).

\begin{tabular}{|c|c|c|c|c|c|c|c|c|c|c|}
\hline Core & $\begin{array}{c}\text { Date } \\
\text { (Aug 2013) }\end{array}$ & $\begin{array}{l}\text { Time } \\
\text { (h) }\end{array}$ & $\begin{array}{l}\text { Top depth } \\
\text { of cored } \\
\text { interval } \\
\text { DSF }(m)\end{array}$ & $\begin{array}{l}\text { Bottom depth } \\
\text { of cored } \\
\text { interval } \\
\text { DSF (m) }\end{array}$ & $\begin{array}{l}\text { Interval } \\
\text { advanced } \\
(\mathrm{m})\end{array}$ & $\begin{array}{l}\text { Top depth } \\
\text { of recovered } \\
\text { core } \\
\text { CSF }(m)\end{array}$ & $\begin{array}{c}\text { Bottom depth } \\
\text { of recovered } \\
\text { core } \\
\text { CSF }(m)\end{array}$ & $\begin{array}{l}\text { Length of } \\
\text { core } \\
\text { recovered } \\
\text { (m) }\end{array}$ & $\begin{array}{l}\text { Curated } \\
\text { length } \\
(\mathrm{m})\end{array}$ & $\begin{array}{c}\text { Recovery } \\
\text { (\%) }\end{array}$ \\
\hline $33 x$ & 18 & 1220 & 255.7 & 257.7 & 2.0 & 255.7 & 256.69 & 0.99 & 0.99 & 50 \\
\hline $34 X$ & 18 & 1255 & 257.7 & 264.7 & 7.0 & 257.7 & 257.70 & & 0 & \\
\hline $35 x$ & 18 & 1335 & 264.7 & 272.4 & 7.7 & 264.7 & 264.70 & & 0 & \\
\hline $36 x$ & 18 & 1425 & 272.4 & 274.1 & 1.7 & 272.4 & 273.01 & 0.61 & 0.61 & 36 \\
\hline \multirow[t]{2}{*}{$37 \mathrm{H}$} & 18 & 1505 & 274.1 & 275.0 & 0.9 & 274.1 & 275.02 & 0.92 & 0.92 & 102 \\
\hline & & & \multicolumn{2}{|c|}{ Total advanced $(\mathrm{m})$} & 143.3 & \multicolumn{2}{|c|}{ Total recovered $(\mathrm{m})$} & 145.85 & & \\
\hline \multicolumn{11}{|c|}{ 346-U1430C- } \\
\hline $1 \mathrm{H}$ & 17 & 1840 & 0.0 & 4.8 & 4.8 & 0.0 & 4.78 & 4.78 & 4.78 & 100 \\
\hline $2 \mathrm{H}$ & 17 & 1905 & 4.8 & 14.3 & 9.5 & 4.8 & 14.40 & 9.60 & 9.60 & 101 \\
\hline $3 \mathrm{H}$ & 17 & 1930 & 14.3 & 23.8 & 9.5 & 14.3 & 24.20 & 9.90 & 9.90 & 104 \\
\hline $4 \mathrm{H}$ & 17 & 1955 & 23.8 & 33.3 & 9.5 & 23.8 & 33.61 & 9.81 & 9.81 & 103 \\
\hline $5 \mathrm{H}$ & 17 & 2020 & 33.3 & 42.8 & 9.5 & 33.3 & 43.18 & 9.88 & 9.88 & 104 \\
\hline $6 \mathrm{H}$ & 17 & 2055 & 42.8 & 52.3 & 9.5 & 42.8 & 52.59 & 9.79 & 9.79 & 103 \\
\hline $7 \mathrm{H}$ & 17 & 2120 & 52.3 & 61.8 & 9.5 & 52.3 & 61.96 & 9.66 & 9.66 & 102 \\
\hline $8 \mathrm{H}$ & 17 & 2145 & 61.8 & 71.3 & 9.5 & 61.8 & 71.83 & 10.03 & 10.03 & 106 \\
\hline $9 \mathrm{H}$ & 17 & 2210 & 71.3 & 80.8 & 9.5 & 71.3 & 81.13 & 9.83 & 9.83 & 103 \\
\hline $10 \mathrm{H}$ & 17 & 2310 & 80.8 & 90.3 & 9.5 & 80.8 & 90.58 & 9.78 & 9.78 & 103 \\
\hline $11 \mathrm{H}$ & 17 & 2335 & 90.3 & 99.8 & 9.5 & 90.3 & 100.17 & 9.87 & 9.87 & 104 \\
\hline $12 \mathrm{H}$ & 18 & 0000 & 99.8 & 109.3 & 9.5 & 99.8 & 109.58 & 9.78 & 9.78 & 103 \\
\hline $13 \mathrm{H}$ & 18 & 0030 & 109.3 & 118.8 & 9.5 & 109.3 & 118.96 & 9.66 & 9.66 & 102 \\
\hline $14 \mathrm{H}$ & 18 & 0055 & 118.8 & 123.5 & 4.7 & 118.8 & 123.78 & 4.98 & 4.98 & 106 \\
\hline $15 \mathrm{H}$ & 18 & 0120 & 123.5 & 133.0 & 9.5 & 123.5 & 133.38 & 9.88 & 9.88 & 104 \\
\hline $16 \mathrm{H}$ & 18 & 0145 & 133.0 & 142.5 & 9.5 & 133.0 & 142.95 & 9.95 & 9.95 & 105 \\
\hline $17 \mathrm{H}$ & 18 & 0210 & 142.5 & 152.0 & 9.5 & 142.5 & 152.35 & 9.85 & 9.85 & 104 \\
\hline $18 \mathrm{H}$ & 18 & 0235 & 152.0 & 161.5 & 9.5 & 152.0 & 161.89 & 9.89 & 9.89 & 104 \\
\hline $19 \mathrm{H}$ & 18 & 0300 & 161.5 & 171.0 & 9.5 & 161.5 & 171.45 & 9.95 & 9.95 & 105 \\
\hline $20 \mathrm{H}$ & 18 & 0325 & 171.0 & 180.5 & 9.5 & 171.0 & 180.74 & 9.74 & 9.74 & 103 \\
\hline $21 \mathrm{H}$ & 18 & 0350 & 180.5 & 190.0 & 9.5 & 180.5 & 190.36 & 9.86 & 9.86 & 104 \\
\hline $22 \mathrm{H}$ & 18 & 0415 & 190.0 & 199.5 & 9.5 & 190.0 & 199.92 & 9.92 & 9.92 & 104 \\
\hline $23 \mathrm{H}$ & 18 & 0440 & 199.5 & 209.0 & 9.5 & 199.5 & 209.40 & 9.90 & 9.90 & 104 \\
\hline $24 \mathrm{H}$ & 18 & 0505 & 209.0 & 218.5 & 9.5 & 209.0 & 218.67 & 9.67 & 9.67 & 102 \\
\hline $25 \mathrm{H}$ & 18 & 0545 & 218.5 & 227.2 & 8.7 & 218.5 & 227.24 & 8.74 & 8.74 & 100 \\
\hline $26 \mathrm{H}$ & 18 & 0630 & 227.2 & 227.3 & 0.1 & 227.2 & 227.33 & 0.13 & 0.13 & 130 \\
\hline $27 X$ & 18 & 0705 & 227.3 & 228.8 & 1.5 & 227.3 & 227.35 & 0.05 & 0.05 & 3 \\
\hline $28 \mathrm{H}$ & 18 & 0730 & 228.8 & 233.5 & 4.7 & 228.8 & 233.62 & 4.82 & 4.82 & 103 \\
\hline $29 \mathrm{H}$ & 18 & 0920 & 233.5 & 238.2 & 4.7 & 233.5 & 238.52 & 5.02 & 5.02 & 107 \\
\hline $30 \mathrm{H}$ & 18 & 1010 & 238.2 & 242.9 & 4.7 & 238.2 & 243.06 & 4.86 & 4.86 & 103 \\
\hline $31 \mathrm{H}$ & 18 & 1045 & 242.9 & 244.6 & 1.7 & 242.9 & 244.66 & 1.76 & 1.76 & 104 \\
\hline $32 \mathrm{H}$ & 18 & 1135 & 244.6 & 248.6 & 4.0 & 244.6 & 248.59 & 3.99 & 3.99 & 100 \\
\hline $33 \mathrm{H}$ & 18 & 1220 & 248.6 & 249.1 & 0.5 & 248.6 & 249.37 & 0.77 & 0.77 & 154 \\
\hline \multirow[t]{2}{*}{$34 \mathrm{H}$} & 18 & 1255 & 249.1 & 250.0 & 0.9 & 249.1 & 250.02 & 0.92 & 0.92 & 102 \\
\hline & & & \multicolumn{2}{|c|}{ Total advanced $(\mathrm{m})$ : } & 250.0 & \multicolumn{2}{|c|}{ Total recovered $(\mathrm{m})$} & 257.02 & & \\
\hline
\end{tabular}

$\mathrm{DRF}=$ drilling depth below rig floor, $\mathrm{DSF}=$ drilling depth below seafloor, $\mathrm{CSF}=$ core depth below seafloor. $\mathrm{APC}=\mathrm{advanced}$ piston corer, $\mathrm{XCB}=$ extended core barrel, $\mathrm{RCB}=$ rotary core barrel. $\mathrm{H}=\mathrm{APC}$ system, $\mathrm{X}=\mathrm{XCB}$ system. $\mathrm{NA}=$ not applicable. 
Table T2. Visible tephra layers thicker than $0.5 \mathrm{~cm}$, Hole U1430A. (Continued on next page.)

\begin{tabular}{|c|c|c|c|c|c|}
\hline $\begin{array}{l}\text { Core, section, } \\
\text { interval }(\mathrm{cm})\end{array}$ & $\begin{array}{c}\text { Top } \\
\text { depth } \\
\text { CSF-A (m) }\end{array}$ & $\begin{array}{c}\text { Bottom } \\
\text { depth } \\
\text { CSF-A (m) }\end{array}$ & $\begin{array}{l}\text { Thickness } \\
(\mathrm{cm})\end{array}$ & Color & Occurrence \\
\hline \multicolumn{6}{|l|}{ 346-U1430A- } \\
\hline $1 \mathrm{H}-2,50-51$ & 2.00 & 2.01 & 1.0 & Light gray & Layered \\
\hline $1 \mathrm{H}-3,54-57$ & 3.44 & 3.47 & 3.0 & Light gray & Layered \\
\hline $2 \mathrm{H}-2,0-3$ & 5.10 & 5.13 & 3.0 & White & Layered \\
\hline $2 \mathrm{H}-3,36-42$ & 6.96 & 7.02 & 6.0 & White & Layered \\
\hline $2 \mathrm{H}-3,97-98$ & 7.57 & 7.58 & 1.0 & Dark gray & Layered \\
\hline $2 \mathrm{H}-4,28-28.5$ & 8.38 & 8.39 & 0.5 & Light gray & Layered \\
\hline $2 \mathrm{H}-4,30-30.5$ & 8.40 & 8.41 & 0.5 & Dark gray & Layered \\
\hline $2 \mathrm{H}-4,56-62$ & 8.66 & 8.72 & 6.0 & Black & Layered \\
\hline $2 \mathrm{H}-5,115-123$ & 10.75 & 10.83 & 8.0 & White & Layered \\
\hline $2 \mathrm{H}-6,40-40.5$ & 11.50 & 11.505 & 0.5 & Dark gray & Layered \\
\hline $2 \mathrm{H}-7,6-13$ & 12.66 & 12.73 & 7.0 & Light gray & Layered \\
\hline $3 \mathrm{H}-1,88-99$ & 13.98 & 14.09 & 11.0 & White & Layered \\
\hline $3 \mathrm{H}-1,116-120$ & 14.26 & 14.30 & 4.0 & White & Layered \\
\hline $3 \mathrm{H}-3,115-120$ & 17.25 & 17.30 & 5.0 & Light gray & Layered \\
\hline $3 \mathrm{H}-4,21-29$ & 17.81 & 17.89 & 8.0 & Gray & Layered \\
\hline $3 \mathrm{H}-4,123-126$ & 18.83 & 18.86 & 3.0 & Light gray & Layered \\
\hline $3 \mathrm{H}-5,9-9.5$ & 19.19 & 19.195 & 0.5 & Black & Layered \\
\hline $3 \mathrm{H}-5,34.5-35$ & 19.445 & 19.45 & 0.5 & Gray & Layered \\
\hline $3 \mathrm{H}-5,45-49$ & 19.55 & 19.59 & 4.0 & White & Layered \\
\hline $3 \mathrm{H}-5,60.5-62$ & 19.705 & 19.72 & 1.5 & Dark gray & Layered \\
\hline $3 \mathrm{H}-5,111-112$ & 20.215 & 20.225 & 1.0 & Black & Layered \\
\hline $3 \mathrm{H}-5,122-122.5$ & 20.32 & 20.325 & 0.5 & Black & Layered \\
\hline $3 \mathrm{H}-5,123-125$ & 20.33 & 20.35 & 2.0 & Gray & Layered \\
\hline $3 \mathrm{H}-5,131-132$ & 20.41 & 20.42 & 1.0 & Very dark gray & Layered \\
\hline $3 \mathrm{H}-6,39-40$ & 20.99 & 21.00 & 1.0 & Black & Layered \\
\hline $3 \mathrm{H}-6,43.5-44$ & 21.035 & 21.04 & 0.5 & Gray & Layered \\
\hline $3 \mathrm{H}-6,60-62$ & 21.20 & 21.22 & 2.0 & Gray & Layered \\
\hline $3 \mathrm{H}-6,65-66$ & 21.25 & 21.26 & 1.0 & Gray & Layered \\
\hline $3 \mathrm{H}-\mathrm{CC}, 14-16$ & 22.79 & 22.81 & 2.0 & Gray & Layered \\
\hline $4 \mathrm{H}-1,0-13$ & 22.60 & 22.73 & 13.0 & White & Layered \\
\hline $4 \mathrm{H}-1,24-25$ & 22.84 & 22.85 & 1.0 & Gray & Layered \\
\hline $4 \mathrm{H}-1,28-40$ & 22.88 & 23.00 & 12.0 & White & Layered \\
\hline $4 \mathrm{H}-1,64-68$ & 23.24 & 23.28 & 4.0 & Gray & Layered \\
\hline $4 \mathrm{H}-1,126-129$ & 23.86 & 23.89 & 3.0 & White & Layered \\
\hline $4 \mathrm{H}-2,58-66$ & 24.68 & 24.76 & 8.0 & White & Layered \\
\hline $4 \mathrm{H}-3,125-125.5$ & 26.85 & 26.86 & 0.5 & Dark gray & Layered \\
\hline $4 \mathrm{H}-3,133-133.5$ & 26.93 & 26.94 & 0.5 & Dark gray & Layered \\
\hline $4 \mathrm{H}-4,38-39$ & 27.48 & 27.49 & 1.0 & Gray & Layered \\
\hline $4 \mathrm{H}-4,61-62$ & 27.71 & 27.72 & 1.0 & Gray & Layered \\
\hline $4 \mathrm{H}-4,77-78$ & 27.87 & 27.88 & 1.0 & Gray & Layered \\
\hline $4 \mathrm{H}-4,117-118$ & 28.27 & 28.28 & 1.0 & Gray & Layered \\
\hline $4 \mathrm{H}-5,45-66$ & 29.05 & 29.26 & 21.0 & White & Layered \\
\hline $4 \mathrm{H}-5,100-105$ & 29.60 & 29.65 & 5.0 & White & Layered \\
\hline $4 \mathrm{H}-5,117-118$ & 29.77 & 29.78 & 1.0 & Gray & Layered \\
\hline $4 \mathrm{H}-7,2-3$ & 31.24 & 31.25 & 1.0 & Gray & Layered \\
\hline $4 \mathrm{H}-7,4-7$ & 31.26 & 31.29 & 3.0 & Gray & Layered \\
\hline $4 \mathrm{H}-7,15-18$ & 31.37 & 31.40 & 3.0 & Dark gray & Layered \\
\hline $4 \mathrm{H}-7,33-34.5$ & 31.55 & 31.565 & 1.5 & Gray & Layered \\
\hline $4 \mathrm{H}-7,36-37$ & 31.58 & 31.59 & 1.0 & Gray & Layered \\
\hline $4 \mathrm{H}-7,50-54$ & 31.72 & 31.76 & 4.0 & Gray & Layered \\
\hline $4 \mathrm{H}-7,61-63$ & 31.83 & 31.85 & 2.0 & Gray & Layered \\
\hline $4 \mathrm{H}-\mathrm{CC}, 4-6$ & 31.98 & 32.00 & 2.0 & Gray & Layered \\
\hline $4 \mathrm{H}-\mathrm{CC}, 12-13$ & 32.06 & 32.07 & 1.0 & Gray & Layered \\
\hline $4 \mathrm{H}-\mathrm{CC}, 18-19.5$ & 32.12 & 32.135 & 1.5 & Gray & Layered \\
\hline $5 \mathrm{H}-1,0-29$ & 32.10 & 32.39 & 29.0 & White & Layered \\
\hline $5 \mathrm{H}-1,72-78$ & 32.82 & 32.88 & 2.0 & Gray & Layered \\
\hline $5 \mathrm{H}-1,80-83$ & 32.90 & 32.93 & 3.0 & Gray & Layered \\
\hline $5 \mathrm{H}-2,0-9$ & 33.60 & 33.69 & 9.0 & Light gray & Layered \\
\hline $5 \mathrm{H}-2,103-105$ & 34.63 & 34.65 & 2.0 & Gray & Layered \\
\hline $5 \mathrm{H}-3,65-68$ & 35.75 & 35.78 & 3.0 & Gray & Layered \\
\hline $5 \mathrm{H}-3,70-71$ & 35.80 & 35.81 & 1.0 & Gray & Layered \\
\hline $5 \mathrm{H}-4,36-37$ & 36.96 & 36.97 & 1.0 & White & Layered \\
\hline $5 \mathrm{H}-6,56.5-57.5$ & 40.165 & 40.175 & 1.0 & Gray & Layered \\
\hline $5 \mathrm{H}-6,146.5-147$ & 41.065 & 41.07 & 0.5 & Dark gray & Layered \\
\hline $6 \mathrm{H}-1,89-90$ & 42.49 & 42.50 & 1.0 & Gray & Layered \\
\hline $6 \mathrm{H}-1,96-97$ & 42.56 & 42.57 & 1.0 & Dark gray & Layered \\
\hline $6 \mathrm{H}-2,60-61$ & 43.70 & 43.71 & 1.0 & Dark gray & Layered \\
\hline
\end{tabular}


Table T2 (continued).

\begin{tabular}{lcccll}
\hline $\begin{array}{c}\text { Core, section, } \\
\text { interval }(\mathrm{cm})\end{array}$ & $\begin{array}{c}\text { Top } \\
\text { depth } \\
\text { CSF-A }(\mathrm{m})\end{array}$ & $\begin{array}{c}\text { Bottom } \\
\text { depth } \\
\text { CSF-A }(\mathrm{m})\end{array}$ & $\begin{array}{c}\text { Thickness } \\
(\mathrm{cm})\end{array}$ & \multicolumn{1}{c}{ Color } & Occurrence \\
\hline $6 \mathrm{H}-2,64-66$ & 43.74 & 43.76 & 2.0 & Gray & Layered \\
$6 \mathrm{H}-2,68-68.5$ & 43.78 & 43.79 & 0.5 & Dark gray & Layered \\
$6 \mathrm{H}-2,75-76$ & 43.85 & 43.86 & 1.0 & Gray & Layered \\
$6 \mathrm{H}-2,112-116$ & 44.22 & 44.26 & 4.0 & White & Layered \\
$6 \mathrm{H}-2,130.5-131$ & 44.405 & 44.41 & 0.5 & Dark gray & Layered \\
$6 \mathrm{H}-3,22-23$ & 44.82 & 44.83 & 1.0 & Gray & Layered \\
$6 \mathrm{H}-3,58-59$ & 45.18 & 45.19 & 1.0 & White & Layered \\
$6 \mathrm{H}-\mathrm{CC}, 16-23$ & 51.35 & 51.42 & 7.0 & Gray & Layered \\
$7 \mathrm{H}-1,8-23$ & 59.10 & 51.33 & 15.0 & White & Layered \\
$22 \mathrm{H}-2,126-129$ & 195.76 & 195.79 & 3.0 & Gray & Layered \\
$22 \mathrm{H}-3,51-55$ & 196.51 & 196.55 & 4.0 & Light gray & Layered \\
$23 \mathrm{H}-5,14-15$ & 208.34 & 208.35 & 1.0 & Very dark gray & Layered \\
\hline
\end{tabular}




\begin{tabular}{|c|c|c|c|c|c|c|c|c|c|c|c|c|c|c|}
\hline $\begin{array}{l}\text { Hole, core, section, } \\
\text { interval }(\mathrm{cm})\end{array}$ & $\begin{array}{l}\text { Top depth } \\
\text { CSF-A (m) }\end{array}$ & $\begin{array}{l}\text { Smectite } \\
\text { (counts) }\end{array}$ & $\begin{array}{c}\text { Illite } \\
\text { (counts) }\end{array}$ & $\begin{array}{l}\text { Kaolinite } \\
\text { + chlorite } \\
\text { (counts) }\end{array}$ & $\begin{array}{l}\text { Quartz } \\
\text { (counts) }\end{array}$ & $\begin{array}{l}\text { K-feldspar } \\
\text { (counts) }\end{array}$ & $\begin{array}{l}\text { Plagioclase } \\
\text { (counts) }\end{array}$ & $\begin{array}{l}\text { Calcite } \\
\text { (counts) }\end{array}$ & $\begin{array}{l}\text { Dolomite } \\
\text { (counts) }\end{array}$ & $\begin{array}{l}\text { Halite } \\
\text { (counts) }\end{array}$ & $\begin{array}{l}\text { Pyrite } \\
\text { (counts) }\end{array}$ & $\begin{array}{l}\text { Opal-A } \\
\text { (counts) }\end{array}$ & $\begin{array}{l}\text { Opal-CT } \\
\text { (counts) }\end{array}$ & $\begin{array}{l}\text { Hydroxlapatite } \\
\text { (counts) }\end{array}$ \\
\hline \multicolumn{15}{|l|}{$346-$} \\
\hline U1430A-1H-2, 74.0-75.0 & 2.24 & 276 & 619 & 441 & 5,237 & 339 & 687 & 882 & 117 & 319 & 102 & 21 & 0 & 0 \\
\hline U1430A-2H-6, 24.0-25.0 & 11.34 & 543 & 1,511 & 826 & 5,475 & 421 & 939 & 406 & 215 & 283 & 67 & 0 & 0 & 0 \\
\hline U1430A-3H-2, 79.0-80.0 & 15.39 & 215 & 433 & 252 & 3,785 & 331 & 448 & 1,836 & 74 & 239 & 94 & 0 & 0 & 0 \\
\hline U1430A-4H-3, 22.0-23.0 & 25.82 & 258 & 673 & 382 & 4,362 & 485 & 613 & 2,626 & 82 & 205 & 90 & 0 & 0 & 0 \\
\hline U1430A-5H-2, 59.0-60.0 & 34.19 & 369 & 757 & 502 & 4,173 & 198 & 597 & 2,955 & 139 & 187 & 104 & 0 & 0 & 0 \\
\hline U1430A-5H-4, 29.0-30.0 & 36.89 & 148 & 407 & 260 & 3,225 & 406 & 496 & 0 & 94 & 274 & 135 & 57 & 0 & 0 \\
\hline U1430A-6H-6, 49.0-50.0 & 49.59 & 356 & 751 & 81 & 4,519 & 261 & 676 & 2,014 & 170 & 129 & 66 & 0 & 0 & 0 \\
\hline U1430A-6H-CC, 1.0-2.0 & 51.2 & 170 & 426 & 239 & 4,785 & 348 & 661 & 0 & 0 & 214 & 77 & 49 & 0 & 0 \\
\hline U1430A-7H-3, 37.0-38.0 & 54.47 & 183 & 575 & 263 & 4,227 & 207 & 469 & 0 & 84 & 294 & 126 & 60 & 0 & 0 \\
\hline U1430A-8H-6, 23.0-24.0 & 68.33 & 220 & 621 & 304 & 4,017 & 250 & 456 & 0 & 72 & 226 & 115 & 39 & 0 & 0 \\
\hline U1430A-9H-1, 99.0-100.0 & 71.09 & 183 & 560 & 264 & 3,407 & 258 & 441 & 0 & 0 & 180 & 90 & 34 & 0 & 0 \\
\hline U1430A-10H-1, $117.0-118.0$ & 80.77 & 100 & 266 & 138 & 2,439 & 153 & 284 & 0 & 0 & 255 & 195 & 86 & 0 & 0 \\
\hline U1430A-11H-1, 70.0-71.0 & 89.8 & 111 & 233 & 88 & 2,307 & 134 & 309 & 0 & 0 & 350 & 150 & 131 & 0 & 0 \\
\hline $\mathrm{U} 1430 \mathrm{~A}-12 \mathrm{H}-1,127.0-128.0$ & 99.87 & 149 & 361 & 165 & 2,966 & 153 & 344 & 0 & 0 & 193 & 95 & 76 & 0 & 0 \\
\hline U1430A-13H-1, 70.0-71.0 & 108.8 & 113 & 263 & 109 & 2,504 & 237 & 348 & 0 & 0 & 261 & 113 & 90 & 0 & 0 \\
\hline U1430A-14H-1, 91.0-92.0 & 118.51 & 88 & 242 & 143 & 2,742 & 144 & 299 & 0 & 0 & 290 & 90 & 88 & 0 & 0 \\
\hline U1430A-15H-2, 70.0-71.0 & 129.3 & 83 & 293 & 126 & 2,921 & 195 & 419 & 0 & 0 & 230 & 82 & 52 & 0 & 0 \\
\hline U1430A-16H-1, 41.0-42.0 & 137.01 & 0 & 235 & 102 & 2,768 & 177 & 319 & 0 & 0 & 304 & 110 & 69 & 0 & 0 \\
\hline U1430A-17H-2, 77.0-78.0 & 148.37 & 130 & 266 & 126 & 2,752 & 176 & 341 & 0 & 0 & 224 & 84 & 91 & 0 & 0 \\
\hline U1430A-18H-6, 67.0-68.0 & 163.77 & 86 & 212 & 120 & 2,350 & 123 & 289 & 0 & 0 & 299 & 106 & 88 & 0 & 0 \\
\hline U1430A-19H-3, 33.0-34.0 & 168.43 & 143 & 236 & 120 & 2,861 & 198 & 348 & 0 & 0 & 230 & 97 & 58 & 0 & 0 \\
\hline $\mathrm{U} 1430 \mathrm{~A}-20 \mathrm{H}-2,35.0-36.0$ & 176.45 & 130 & 209 & 100 & 2,864 & 174 & 372 & 0 & 0 & 194 & 95 & 52 & 0 & 0 \\
\hline U1430A-21H-1, 96.0-97.0 & 184.46 & 95 & 246 & 142 & 3,008 & 186 & 359 & 0 & 0 & 201 & 125 & 52 & 0 & 0 \\
\hline U1430A-21H-6, 43.0-44.0 & 191.43 & 0 & 132 & 130 & 561 & 0 & 217 & 0 & 0 & 160 & 84 & 0 & 0 & 1,690 \\
\hline U1430A-22H-2, 87.0-88.0 & 195.37 & 0 & 0 & 0 & 71 & 0 & 0 & 0 & 0 & 0 & 0 & 0 & 0 & 471 \\
\hline U1430A-22H-6, 69.0-70.0 & 201.19 & 0 & 245 & 104 & 2,394 & 186 & 261 & 0 & 0 & 325 & 132 & 84 & 0 & 0 \\
\hline U1430A-23H-6, 24.0-25.0 & 209.94 & 97 & 222 & 122 & 2,617 & 236 & 323 & 0 & 0 & 276 & 129 & 90 & 0 & 0 \\
\hline U1430A-24H-3, 37.0-38.0 & 215.07 & 100 & 195 & 122 & 2,798 & 185 & 370 & 0 & 0 & 250 & 100 & 69 & 0 & 0 \\
\hline U1430A-25H-1, 69.0-70.0 & 221.89 & 88 & 206 & 114 & 1,988 & 100 & 234 & 0 & 0 & 365 & 147 & 113 & 0 & 0 \\
\hline U1430C-26H-CC, $11.0-12.0$ & 227.31 & 347 & 0 & 0 & 98 & 0 & 0 & 0 & 9,582 & 0 & 0 & 0 & 0 & 0 \\
\hline U1430A-26H-2, 61.0-62.0 & 232.81 & 83 & 226 & 117 & 2,381 & 139 & 285 & 0 & 0 & 312 & 106 & 107 & 0 & 0 \\
\hline U1430A-27H-3, 56.0-57.0 & 238.96 & 90 & 184 & 113 & 2,560 & 231 & 277 & 0 & 0 & 265 & 109 & 102 & 0 & 0 \\
\hline U1430A-28H-2, 64.0-65.0 & 242.24 & 88 & 235 & 122 & 2,464 & 169 & 311 & 0 & 0 & 198 & 69 & 59 & 0 & 0 \\
\hline U1430A-30X-CC, 22.0-23.0 & 249.72 & 145 & 273 & 261 & 5,699 & 1,502 & 2,179 & 89 & 0 & 0 & 123 & 0 & 581 & 0 \\
\hline U1430B-32X-1, 34.0-35.0 & 250.34 & 115 & 367 & 0 & 2,251 & 1,266 & 1,884 & 0 & 0 & 0 & 179 & 62 & 0 & 0 \\
\hline U1430B-33X-1, 39.0-40.0 & 256.09 & 0 & 0 & 0 & 163 & 0 & 0 & 0 & 0 & 96 & 0 & 0 & 0 & 0 \\
\hline U1430B-33X-1, 61.0-62.0 & 256.31 & 160 & 483 & 0 & 2,145 & 1,444 & 3,785 & 0 & 2,172 & 199 & 81 & 104 & 0 & 0 \\
\hline U1430A-32X-CC, 16.0-18.0 & 264.86 & 186 & 158 & 0 & 1,992 & 398 & 694 & 0 & 6,453 & 0 & 0 & 0 & 0 & 0 \\
\hline U1430B-37H-1, 28.0-29.0 & 274.38 & 330 & 1,721 & 231 & 10,325 & 9,273 & 19,229 & 0 & 0 & 259 & 0 & 0 & 0 & 0 \\
\hline
\end{tabular}


Table T4. Microfossil bioevents, Site U1430.

\begin{tabular}{|c|c|c|c|c|c|c|c|c|c|c|c|c|}
\hline \multicolumn{2}{|c|}{ Core, section, interval $(\mathrm{cm})$} & \multirow[b]{2}{*}{ Event } & \multirow[b]{2}{*}{ Bioevents and epoch boundaries } & \multirow{2}{*}{$\begin{array}{l}\text { Age } \\
\text { (Ma) }\end{array}$} & \multicolumn{4}{|c|}{ Depth CSF-A (m) } & \multicolumn{4}{|c|}{ Depth CCSF-A (m) } \\
\hline Top & Bottom & & & & Top & Bottom & Midpoint & \pm & Top & Bottom & Midpoint & \pm \\
\hline \multirow[t]{2}{*}{ 346-U1430A- } & 346-U1430A- & & & & & & & & & & & \\
\hline & $\begin{array}{l}1 \mathrm{H}-\mathrm{CC} \\
2 \mathrm{H}-\mathrm{CC}\end{array}$ & $\begin{array}{l}\mathrm{R} \\
\mathrm{CN}\end{array}$ & $\begin{array}{l}\text { LO Lychnocanoma sakaii } \\
\text { FO Emiliania huxleyi }\end{array}$ & $\begin{array}{l}0.05 \\
0.29\end{array}$ & $\begin{array}{l}0.00 \\
3.53\end{array}$ & $\begin{array}{r}3.53 \\
13.27\end{array}$ & $\begin{array}{l}1.77 \\
8.40\end{array}$ & $\begin{array}{l}1.77 \\
4.87\end{array}$ & $\begin{array}{l}0.21 \\
3.74\end{array}$ & $\begin{array}{r}3.74 \\
13.63\end{array}$ & $\begin{array}{l}1.98 \\
8.69\end{array}$ & $\begin{array}{l}1.77 \\
4.95\end{array}$ \\
\hline $1 \mathrm{H}-\mathrm{CC}$ & $2 \mathrm{H}-\mathrm{CC}$ & $\mathrm{R}$ & LO Amphimelissa setosa & 0.08 & 3.53 & 13.27 & 8.40 & 4.87 & 3.74 & 13.63 & 8.69 & 4.95 \\
\hline $2 \mathrm{H}-\mathrm{CC}$ & $3 \mathrm{H}-\mathrm{CC}$ & $\mathrm{R}$ & LO Spongodiscus sp. & 0.29 & 13.27 & 22.88 & 18.08 & 4.81 & 13.63 & 23.88 & 18.76 & 5.13 \\
\hline $3 \mathrm{H}-3,57-58$ & $3 \mathrm{H}-\mathrm{CC}$ & $\mathrm{D}$ & LO Proboscia curvirostris & 0.30 & 16.67 & 22.88 & 19.78 & 3.11 & 17.67 & 23.88 & 20.78 & 3.11 \\
\hline $5 \mathrm{H}-\mathrm{CC}$ & $6 \mathrm{H}-\mathrm{CC}$ & $\mathrm{R}$ & LO Axoprunum acquilonium & $1.2-1.7$ & 42.05 & 51.37 & 46.71 & 4.66 & 44.00 & 53.74 & 48.87 & 4.87 \\
\hline $6 \mathrm{H}-\mathrm{CC}$ & 7H-1, 100-101 & $\mathrm{D}$ & LO Neodenticula koizumii & 2.00 & 51.37 & 52.10 & 51.74 & 0.37 & 53.74 & 55.02 & 54.38 & 0.64 \\
\hline $6 \mathrm{H}-\mathrm{CC}$ & 7H-CC & $\mathrm{R}$ & FO Cycladophora davisiana & 2.70 & 51.37 & 61.00 & 56.19 & 4.81 & 53.74 & 63.92 & 58.83 & 5.09 \\
\hline $6 \mathrm{H}-\mathrm{CC}$ & $7 \mathrm{H}-\mathrm{CC}$ & $\mathrm{R}$ & LO Hexacontium parviakitaensis & 2.70 & 51.37 & 61.00 & 56.19 & 4.81 & 53.74 & 63.92 & 58.83 & 5.09 \\
\hline $7 \mathrm{H}-6,55-56$ & 7H-CC & $\mathrm{D}$ & LO Neodenticula kamtschatica & $2.60-2.70$ & 59.15 & 61.00 & 60.08 & 0.92 & 62.07 & 63.92 & 63.00 & 0.92 \\
\hline $8 \mathrm{H}-2,75$ & $8 \mathrm{H}-3,75$ & $\mathrm{D}$ & FO Neodenticula koizumii & $3.40-3.93$ & 62.85 & 64.35 & 63.60 & 0.75 & 66.29 & 67.79 & 67.04 & 0.75 \\
\hline $8 \mathrm{H}-\mathrm{CC}$ & 9H-CC & $\mathrm{R}$ & FO Hexacontium parviakitaensis & $3.9-4.3$ & 70.39 & 79.90 & 75.15 & 4.75 & 73.83 & 83.45 & 78.64 & 4.81 \\
\hline $8 \mathrm{H}-\mathrm{CC}$ & $9 \mathrm{H}-\mathrm{CC}$ & $\mathrm{R}$ & LO Lipmanella redondoensis & 5.06 & 70.39 & 79.90 & 75.15 & 4.75 & 73.83 & 83.45 & 78.64 & 4.81 \\
\hline $8 \mathrm{H}-\mathrm{CC}$ & $9 \mathrm{H}-\mathrm{CC}$ & $\mathrm{R}$ & FO Axoprunum acquilonium & 7.10 & 70.39 & 79.90 & 75.15 & 4.75 & 73.83 & 83.45 & 78.64 & 4.81 \\
\hline $9 \mathrm{H}-\mathrm{CC}$ & $10 \mathrm{H}-\mathrm{CC}$ & $\mathrm{R}$ & FO Larcopyle pylomaticus & 5.30 & 79.90 & 89.46 & 84.68 & 4.78 & 83.45 & 93.91 & 88.68 & 5.23 \\
\hline $9 \mathrm{H}-\mathrm{CC}$ & $10 \mathrm{H}-\mathrm{CC}$ & D & FO Shionodiscus oestrupii & 5.56 & 79.90 & 89.46 & 84.68 & 4.78 & 83.45 & 93.91 & 88.68 & 5.23 \\
\hline $8 \mathrm{H}-\mathrm{CC}$ & $9 \mathrm{H}-\mathrm{CC}$ & $\mathrm{R}$ & LO Cycladophora nakasekoi & 7.40 & 70.39 & 79.90 & 75.15 & 4.75 & 73.83 & 83.45 & 78.64 & 4.81 \\
\hline $10 \mathrm{H}-\mathrm{CC}$ & $11 \mathrm{H}-\mathrm{CC}$ & $\mathrm{D}$ & LCO Thalassionema schraderi & 7.67 & 89.46 & 98.84 & 94.15 & 4.69 & 93.91 & 103.91 & 98.91 & 5.00 \\
\hline $13 \mathrm{H}-\mathrm{CC}$ & $14 \mathrm{H}-\mathrm{CC}$ & $\mathrm{D}$ & FCO Thalassionema schraderi & 8.50 & 117.93 & 127.42 & 122.68 & 4.74 & 124.47 & 134.37 & 129.42 & 4.95 \\
\hline $14 \mathrm{H}-\mathrm{CC}$ & $15 \mathrm{H}-\mathrm{CC}$ & $\mathrm{D}$ & LO Denticulopsis katayamae & 8.70 & 127.42 & 136.91 & 132.17 & 4.75 & 134.37 & 144.28 & 139.32 & 4.95 \\
\hline $15 \mathrm{H}-\mathrm{CC}$ & $16 \mathrm{H}-\mathrm{CC}$ & $\mathrm{R}$ & LCO Lychnocanoma magnacornuta & 9.10 & 136.91 & 146.47 & 141.69 & 4.78 & 144.28 & 154.61 & 149.44 & 5.17 \\
\hline $19 \mathrm{H}-\mathrm{CC}$ & $20 \mathrm{H}-\mathrm{CC}$ & $\mathrm{R}$ & FO Cycladophora nakasekoi & 10.10 & 174.96 & 183.48 & 179.22 & 4.26 & 185.60 & 194.76 & 190.18 & 4.58 \\
\hline $19 \mathrm{H}-\mathrm{CC}$ & $20 \mathrm{H}-\mathrm{CC}$ & $\mathrm{R}$ & LO Cyrtocapsella japonica & 10.10 & 174.96 & 183.48 & 179.22 & 4.26 & 185.60 & 194.76 & 190.18 & 4.58 \\
\hline $19 \mathrm{H}-\mathrm{CC}$ & $20 \mathrm{H}-\mathrm{CC}$ & $\mathrm{D}$ & LO Denticulopsis hustedtii & 10.20 & 174.96 & 183.48 & 179.22 & 4.26 & 185.60 & 194.76 & 190.18 & 4.58 \\
\hline $21 \mathrm{H}-\mathrm{CC}$ & $22 \mathrm{H}-\mathrm{CC}$ & $\mathrm{R}$ & LO Dendrospyris uruyaensis & 10.10 & 192.9 & 202.2 & 197.55 & 4.65 & 204.87 & 215.41 & 210.14 & 5.27 \\
\hline $25 \mathrm{H}-\mathrm{CC}$ & $26 \mathrm{H}-\mathrm{CC}$ & $\mathrm{R}$ & FO Lychnocanoma magnacornuta & 11.80 & 230.65 & 235.64 & 233.15 & 2.50 & 244.36 & 250.24 & 247.30 & 2.94 \\
\hline $27 \mathrm{H}-\mathrm{CC}$ & $28 \mathrm{H}-\mathrm{CC}$ & $\mathrm{R}$ & FO Dendrospyris uruyaensis & 11.80 & 240.38 & 245.06 & 242.72 & 2.34 & 254.99 & 260.25 & 257.62 & 2.63 \\
\hline $27 \mathrm{H}-\mathrm{CC}$ & $28 \mathrm{H}-\mathrm{CC}$ & $\mathrm{R}$ & LO Eucyrtidium inflatum & 11.80 & 240.38 & 245.06 & 242.72 & 2.34 & 254.99 & 260.25 & 257.62 & 2.63 \\
\hline $27 \mathrm{H}-\mathrm{CC}$ & $28 \mathrm{H}-\mathrm{CC}$ & $\mathrm{R}$ & LO Lithopera renzae & 11.80 & 240.38 & 245.06 & 242.72 & 2.34 & 254.99 & 260.25 & 257.62 & 2.63 \\
\hline $27 \mathrm{H}-\mathrm{CC}$ & $28 \mathrm{H}-\mathrm{CC}$ & D & FCO Denticulopsis simonsenii & 13.10 & 240.38 & 245.06 & 242.72 & 2.34 & 254.99 & 260.25 & 257.62 & 2.63 \\
\hline $29 \mathrm{H}-\mathrm{CC}$ & $30 \mathrm{X}-\mathrm{CC}$ & $\mathrm{R}$ & RD Cyrticapsella tetrapera & 12.60 & 249.50 & 249.68 & 249.59 & 0.09 & 264.63 & 264.81 & 264.72 & 0.09 \\
\hline $30 \mathrm{X}-\mathrm{CC}$ & $31 \mathrm{X}-\mathrm{CC}$ & $\mathrm{R}$ & LO Dendrospyris sakaii & 14.80 & 249.68 & 255.07 & 252.38 & 2.69 & 264.81 & 270.20 & 267.50 & 2.69 \\
\hline 346-U1430B- & 346-U1430B- & & & & & & & & & & & \\
\hline $3 \mathrm{H}-\mathrm{CC}$ & $4 \mathrm{H}-\mathrm{CC}$ & $\mathrm{F}$ & LO Neogloboquadrina kagaensis group & 0.70 & 27.58 & 36.89 & 32.24 & 4.66 & 28.02 & 37.86 & 32.94 & 4.92 \\
\hline $4 \mathrm{H}-\mathrm{CC}$ & $5 \mathrm{H}-\mathrm{CC}$ & $\mathrm{F}$ & Neogloboquadrina pachyderma (coiling change, $\mathrm{d}$ to $s$ ) & $1.14-1.24$ & 36.94 & 46.32 & 41.63 & 4.69 & 37.91 & 47.90 & 42.91 & 4.99 \\
\hline $32 X-1,111-113$ & $333 X-1,59-61$ & $\mathrm{R}$ & LO Pentactinosphaera hokurikuensis & 15.0 & 251.11 & 256.29 & 253.70 & 2.59 & 267.45 & 272.63 & 270.04 & 2.59 \\
\hline 346-U1430C- & 346-U1430C- & & & & & & & & & & & \\
\hline $3 \mathrm{H}-\mathrm{CC}$ & $4 \mathrm{H}-\mathrm{CC}$ & $\mathrm{F}$ & LO Neogloboquadrina kagaensis group & 0.70 & 24.20 & 33.56 & 28.88 & 4.68 & 25.04 & 34.43 & 29.73 & 4.70 \\
\hline $29 \mathrm{H}-\mathrm{CC}$ & $30 \mathrm{H}-\mathrm{CC}$ & $\mathrm{R}$ & FO Dendrospyris uruyaensis & 11.80 & 238.47 & 243.01 & 240.74 & 2.27 & 254.36 & 259.30 & 256.83 & 2.47 \\
\hline $29 \mathrm{H}-\mathrm{CC}$ & $30 \mathrm{H}-\mathrm{CC}$ & $\mathrm{R}$ & LO Eucyrtidium inflatum & 11.80 & 238.47 & 243.01 & 240.74 & 2.27 & 254.36 & 259.30 & 256.83 & 2.47 \\
\hline $30 \mathrm{H}-\mathrm{CC}$ & $31 \mathrm{H}-\mathrm{CC}$ & $\mathrm{R}$ & RD Cyrticapsella tetrapera & 12.60 & 243.01 & 244.61 & 243.81 & 0.80 & 259.30 & 260.90 & 260.10 & 0.80 \\
\hline
\end{tabular}

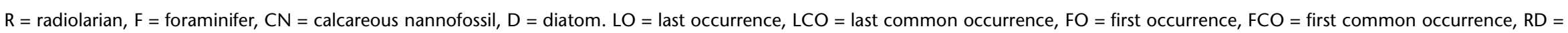
rapid decrease. 
Table T5. Preservation and estimated abundance of calcareous nannofossils, Site U1430.

\begin{tabular}{|c|c|c|c|c|c|c|c|c|}
\hline $\begin{array}{l}\text { Core, section, } \\
\text { interval }(\mathrm{cm})\end{array}$ & $\begin{array}{c}\text { Top } \\
\text { depth } \\
\text { CSF-A (m) }\end{array}$ & $\begin{array}{c}\text { Bottom } \\
\text { depth } \\
\text { CSF-A (m) }\end{array}$ & $\begin{array}{c}\text { Depth } \\
\text { CCSF-A (m) }\end{array}$ & 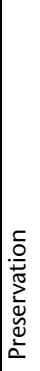 & 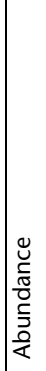 & 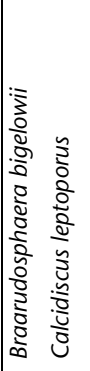 & 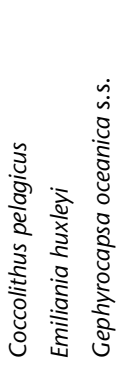 & 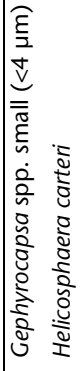 \\
\hline $\begin{array}{l}\text { 346-U1430A- } \\
1 \mathrm{H}-\mathrm{CC}\end{array}$ & 3.53 & 358 & 3.74 & $M$ & $\mathrm{~F}$ & & $\mathrm{R} \quad \mathrm{R}$ & $\mathrm{F}$ \\
\hline $2 \mathrm{H}-\mathrm{CC}$ & 13.27 & 13.33 & 13.63 & $P$ & $\mathrm{R}$ & & $R$ & $\mathrm{R}$ \\
\hline $3 \mathrm{H}-\mathrm{CC}$ & 22.88 & 22.93 & 23.88 & & B & & & \\
\hline $4 \mathrm{H}-\mathrm{CC}$ & 32.17 & 32.22 & 33.98 & $M$ & $\mathrm{R}$ & $\mathrm{R}$ & $\mathrm{R}$ & $\mathrm{F}$ \\
\hline $5 \mathrm{H}-\mathrm{CC}$ & 42.05 & 42.10 & 44.00 & & B & & & \\
\hline $6 \mathrm{H}-3,75$ & 45.35 & 45.35 & 47.72 & $M$ & $\mathrm{~F}$ & & C & $\mathrm{R}$ \\
\hline $6 \mathrm{H}-5,75$ & 48.35 & 48.35 & 50.72 & & B & & & \\
\hline $6 \mathrm{H}-\mathrm{CC}$ & 51.37 & 51.42 & 53.74 & $P$ & $\mathrm{R}$ & & $\mathrm{R}$ & \\
\hline 7H-CC & 61.00 & 61.05 & 63.92 & & B & & & \\
\hline $8 \mathrm{H}-\mathrm{CC}$ & 70.39 & 70.44 & 73.83 & & B & & & \\
\hline 9H-CC & 79.90 & 79.95 & 83.45 & & B & & & \\
\hline $10 \mathrm{H}-\mathrm{CC}$ & 89.46 & 89.51 & 93.91 & & B & & & \\
\hline $11 \mathrm{H}-\mathrm{CC}$ & 98.84 & 98.89 & 103.91 & & B & & & \\
\hline $12 \mathrm{H}-\mathrm{CC}$ & 108.41 & 108.46 & 114.19 & & B & & & \\
\hline $13 \mathrm{H}-\mathrm{CC}$ & 117.93 & 117.98 & 124.47 & & B & & & \\
\hline $14 \mathrm{H}-\mathrm{CC}$ & 127.42 & 127.47 & 134.37 & & B & & & \\
\hline $15 \mathrm{H}-\mathrm{CC}$ & 136.91 & 136.96 & 144.28 & $M$ & $R$ & & & $\mathrm{R}$ \\
\hline $16 \mathrm{H}-\mathrm{CC}$ & 146.47 & 146.52 & 154.61 & & B & & & \\
\hline $17 \mathrm{H}-\mathrm{CC}$ & 155.96 & 156.01 & 165.97 & & B & & & \\
\hline $18 \mathrm{H}-\mathrm{CC}$ & 165.10 & 165.15 & 175.25 & & B & & & \\
\hline $19 \mathrm{H}-1,60$ & 165.70 & 165.70 & 176.34 & & B & & & \\
\hline $19 \mathrm{H}-2,60$ & 167.20 & 167.20 & 177.84 & & B & & & \\
\hline $19 \mathrm{H}-3,60$ & 168.70 & 168.70 & 179.34 & & B & & & \\
\hline $19 \mathrm{H}-4,70$ & 170.30 & 170.30 & 180.94 & & B & & & \\
\hline $19 \mathrm{H}-5,60$ & 171.70 & 171.70 & 182.34 & & B & & & \\
\hline $19 \mathrm{H}-6,80$ & 173.40 & 173.40 & 184.04 & & B & & & \\
\hline $19 \mathrm{H}-7,30$ & 174.40 & 174.40 & 185.04 & & B & & & \\
\hline $19 \mathrm{H}-\mathrm{CC}$ & 174.96 & 175.01 & 185.60 & & B & & & \\
\hline $20 \mathrm{H}-\mathrm{CC}$ & 183.48 & 183.53 & 194.76 & & B & & & \\
\hline $21 \mathrm{H}-\mathrm{CC}$ & 192.90 & 192.95 & 204.87 & & B & & & \\
\hline $22 \mathrm{H}-\mathrm{CC}$ & 202.20 & 202.25 & 215.41 & & B & & & \\
\hline $23 \mathrm{H}-\mathrm{CC}$ & 211.81 & 211.86 & 225.34 & & B & & & \\
\hline $24 \mathrm{H}-\mathrm{CC}$ & 221.43 & 221.48 & 235.36 & & B & & & \\
\hline $25 \mathrm{H}-\mathrm{CC}$ & 230.65 & 230.70 & 244.36 & & B & & & \\
\hline $26 \mathrm{H}-\mathrm{CC}$ & 235.64 & 235.69 & 250.24 & & B & & & \\
\hline $27 \mathrm{H}-\mathrm{CC}$ & 240.38 & 240.43 & 254.99 & & B & & & \\
\hline $28 \mathrm{H}-\mathrm{CC}$ & 245.06 & 245.11 & 260.25 & & B & & & \\
\hline $29 \mathrm{H}-\mathrm{CC}$ & 249.50 & 249.55 & 264.63 & & B & & & \\
\hline $30 \mathrm{X}-\mathrm{CC}$ & 249.68 & 249.73 & 264.81 & & B & & & \\
\hline $31 X-C C$ & 255.07 & 255.12 & 270.20 & & B & & & \\
\hline 346-U1430B- & & & & & & & & \\
\hline $1 \mathrm{H}-\mathrm{CC}$ & 8.22 & 8.27 & 8.22 & $P$ & $\mathrm{R}$ & R & & \\
\hline $2 \mathrm{H}-\mathrm{CC}$ & 17.98 & 18.03 & 18.00 & $P$ & $\mathrm{R}$ & & & $\mathrm{F}$ \\
\hline $3 \mathrm{H}-\mathrm{CC}$ & 27.53 & 27.58 & 27.97 & $P$ & $R$ & $\mathrm{R}$ & $\mathrm{F}$ & C F \\
\hline $4 \mathrm{H}-\mathrm{CC}$ & 36.89 & 36.94 & 37.86 & & B & & & \\
\hline $5 \mathrm{H}-\mathrm{CC}$ & 46.32 & 46.37 & 47.90 & & B & & & \\
\hline $6 \mathrm{H}-\mathrm{CC}$ & 55.82 & 55.87 & 57.83 & & B & & & \\
\hline 7H-CC & 65.51 & 65.56 & 67.95 & & B & & & \\
\hline $8 \mathrm{H}-\mathrm{CC}$ & 75.07 & 75.12 & 78.09 & & B & & & \\
\hline 9H-CC & 84.55 & 84.60 & 87.86 & & B & & & \\
\hline $10 \mathrm{H}-\mathrm{CC}$ & 93.82 & 93.86 & 98.05 & & B & & & \\
\hline $11 \mathrm{H}-\mathrm{CC}$ & 103.56 & 103.61 & 108.30 & & B & & & \\
\hline $12 \mathrm{H}-\mathrm{CC}$ & 113.08 & 113.13 & 118.38 & & B & & & \\
\hline $13 \mathrm{H}-\mathrm{CC}$ & 122.64 & 122.69 & 128.60 & & B & & & \\
\hline $14 \mathrm{H}-\mathrm{CC}$ & 131.75 & 131.77 & 138.34 & & B & & & \\
\hline $29 \mathrm{X}-\mathrm{CC}$ & 246.00 & 246.05 & 262.34 & & B & & & \\
\hline
\end{tabular}

Preservation: $\mathrm{M}=$ moderate, $\mathrm{P}=$ poor. Abundance: $\mathrm{C}=$ common, $\mathrm{F}=$ few $\mathrm{R}=$ rare $\mathrm{B}=$ barren. Shaded intervals $=$ barren. 
Table T6. Preservation and estimated abundance of radiolarians, Site U1430.

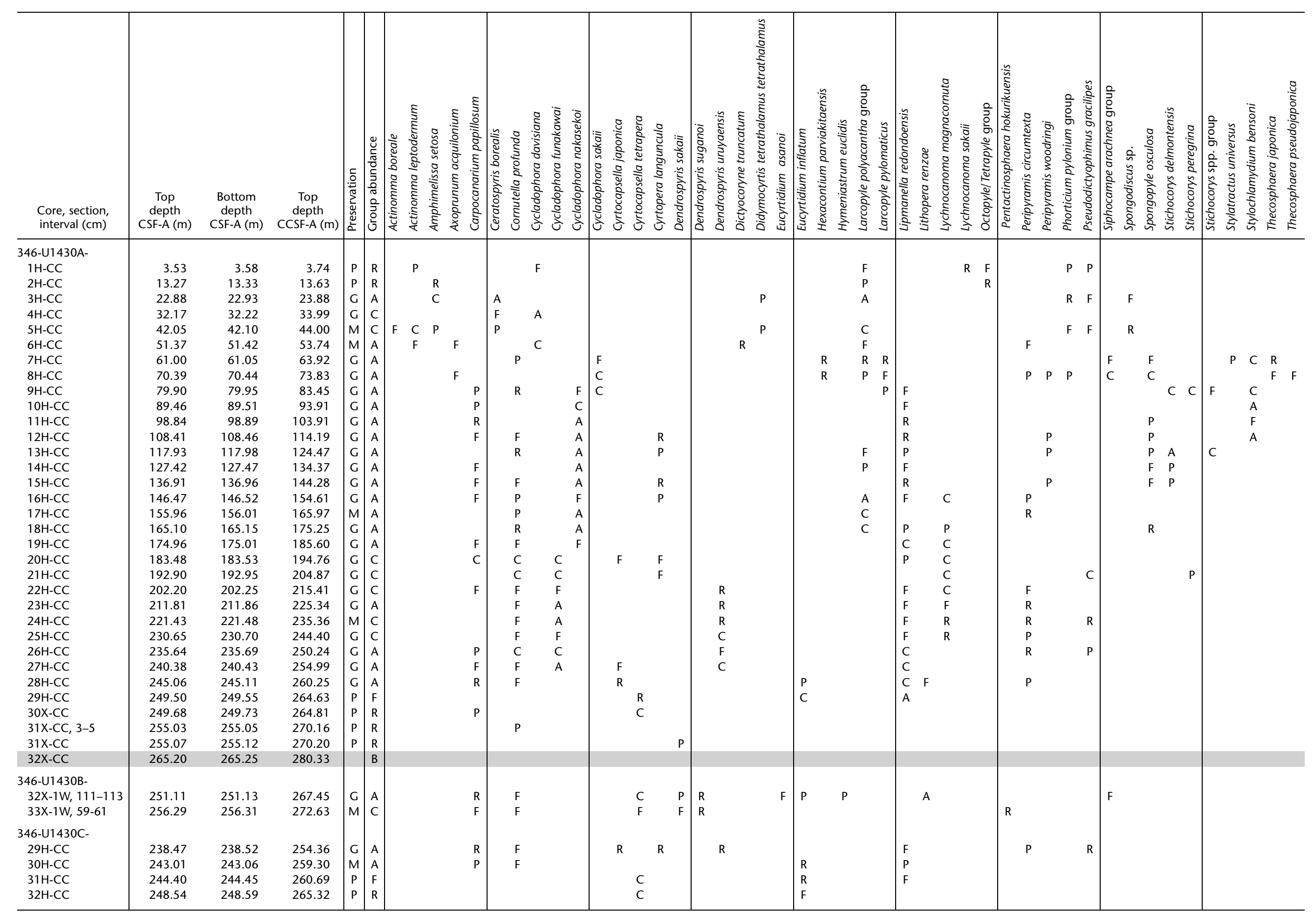

Preservation: $\mathrm{G}=$ good, $\mathrm{M}=$ moderate, $\mathrm{P}=$ poor. Abundance: $\mathrm{A}=$ abundant, $\mathrm{C}=$ common, $\mathrm{F}=$ few, $\mathrm{R}=$ rare, $\mathrm{P}=$ present, $\mathrm{B}=$ barren. Shaded interval $=$ barren 
Table T7. Preservation and estimated abundance of diatoms, Hole U1430A.

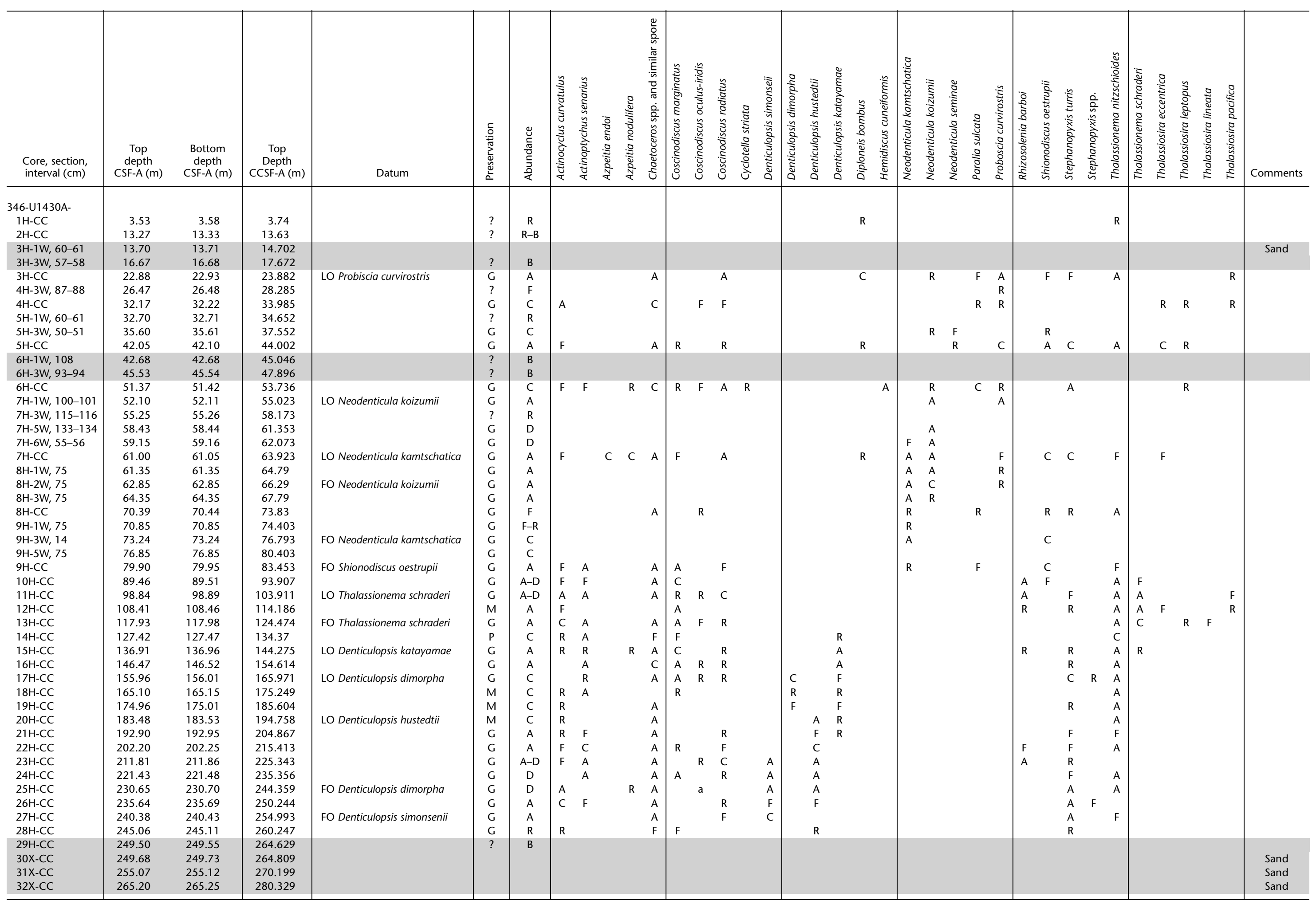

Preservation: $\mathrm{G}=$ good, $\mathrm{M}=$ moderate, $\mathrm{P}=$ poor. Abundance: $\mathrm{D}=$ dominant, $\mathrm{A}=$ abundant, $\mathrm{C}=$ common, $\mathrm{F}=$ few, $\mathrm{R}=$ rare, $\mathrm{B}=$ barren, ? $=$ the sample does not allow an assessment of the preservation. $\mathrm{LO}=$ last occurrence, $\mathrm{FO}=$ first occurrence. Shaded intervals $=$ barren. 
Table T8. Preservation and estimated abundance of planktonic foraminifers, Site U1430.

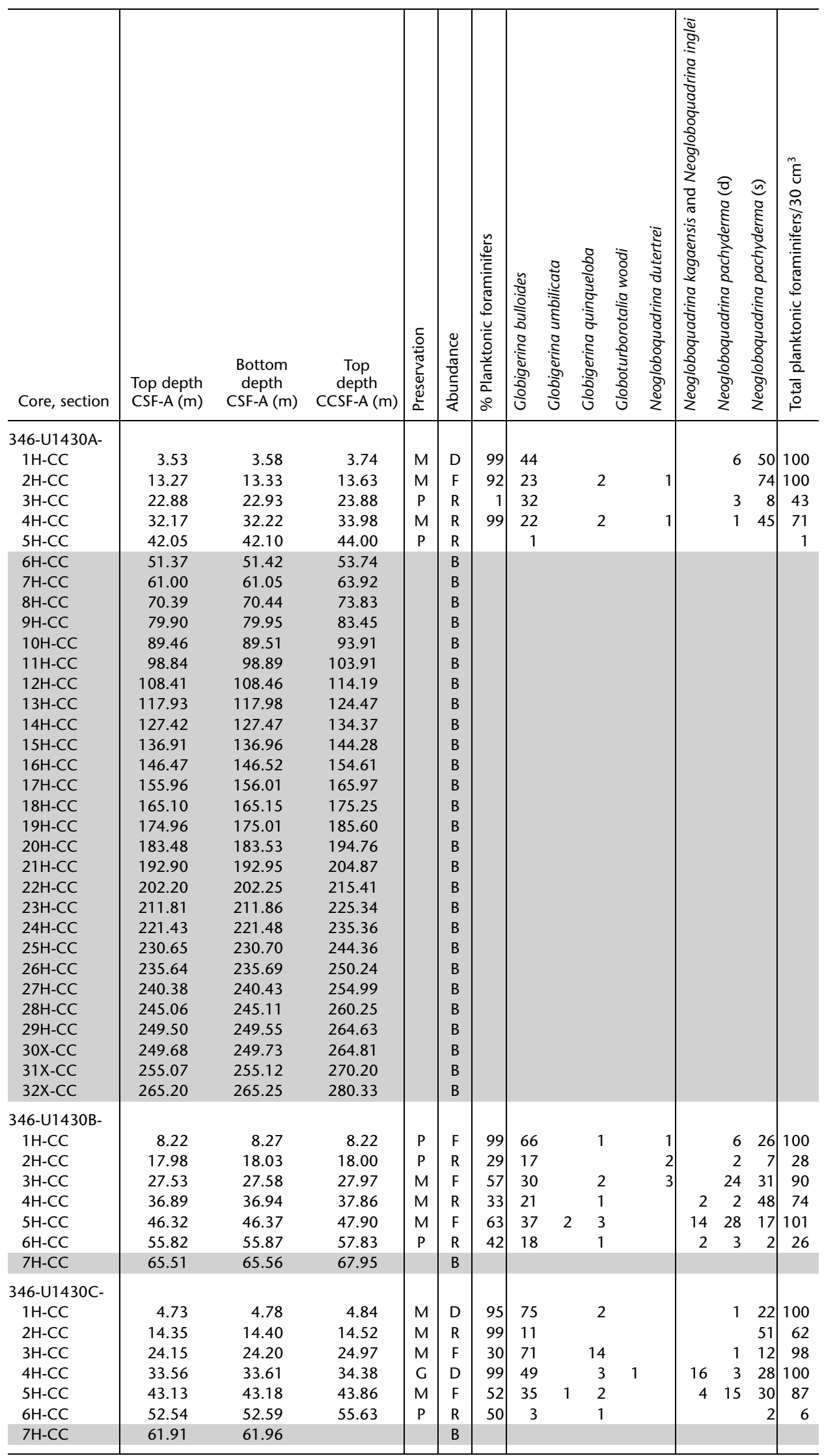

Preservation: $\mathrm{G}=$ good, $\mathrm{M}=$ moderate, $\mathrm{P}=$ poor. Abundance: $\mathrm{D}=$ dominant, $\mathrm{F}=\mathrm{few}, \mathrm{R}=$ rare, $\mathrm{B}=$ barren. Shaded intervals $=$ barren. 
Table T9. Benthic foraminifers, Site U1430.

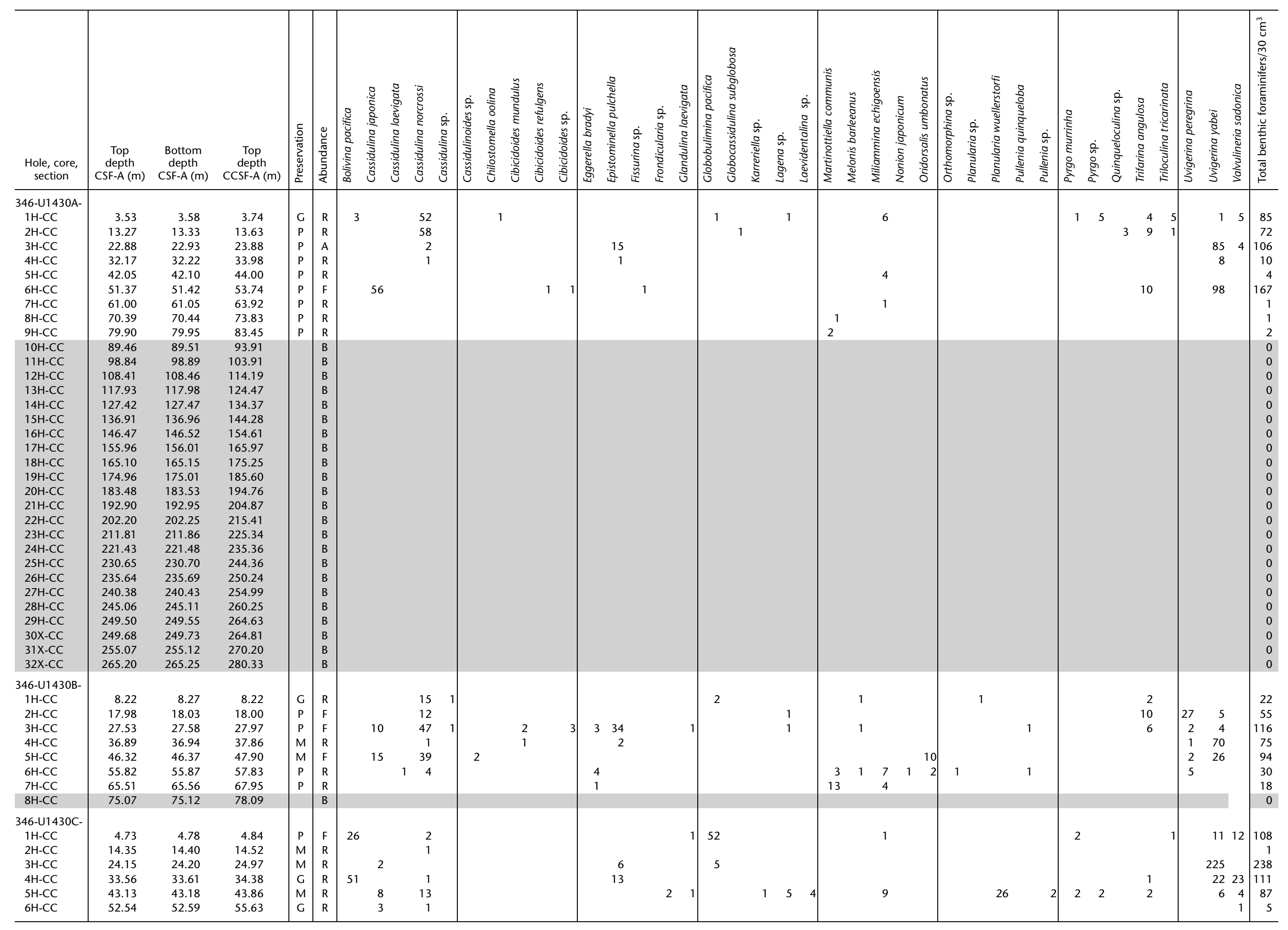

Numbers of foraminifers $(>150 \mu \mathrm{m})$ per $10 \mathrm{~cm}^{3}$ are underestimated in samples with $>100$ specimens, as these samples were not completely picked. Preservation: $G=$ good, $M=$ moderate, $P=$ poor. Abundance: $D=$ dominant, $F=$ few, $R=$ rare, $B=$ barren. Shaded intervals $=$ barren. 
Table T10. Interstitial water chemistry, Site U1430.

\begin{tabular}{|c|c|c|c|c|c|c|c|c|c|c|c|c|c|c|c|c|c|c|c|c|c|c|}
\hline $\begin{array}{l}\text { Core, section, } \\
\text { interval }(\mathrm{cm})\end{array}$ & $\begin{array}{l}\text { Top depth } \\
\text { CSF-A }(m)\end{array}$ & $\begin{array}{c}\text { Sample } \\
\text { type }\end{array}$ & $\begin{array}{l}\text { Alkalinity } \\
\text { (mMM) } \\
\text { Titration }\end{array}$ & $\begin{array}{l}\mathrm{pH} \\
\mathrm{iSE}\end{array}$ & $\begin{array}{l}\text { Salinity } \\
\text { (\%or) } \\
\text { Refract }\end{array}$ & $\begin{array}{c}\mathrm{Cl} \\
(\mathrm{Cl}) \\
\text { Titration }\end{array}$ & $\begin{array}{c}\mathrm{Cl}^{\mathrm{C}} \\
(\mathrm{mM}) \\
\mathrm{Cl}\end{array}$ & $\begin{array}{c}\mathrm{SO}_{4} \mathrm{C}^{2} \\
(\mathrm{mM}) \\
\mathrm{IC}\end{array}$ & $\begin{array}{c}\mathrm{Br} \\
(\mathrm{mM}) \\
\mathrm{IC}\end{array}$ & $\begin{array}{c}\mathrm{Na} \\
(\mathrm{mM}) \\
\mathrm{MM}\end{array}$ & $\begin{array}{c}\mathrm{Ca} \\
\underset{(\mathrm{mM})}{\mathrm{ICP}}\end{array}$ & $\begin{array}{c}\mathrm{Mg} \\
(\mathrm{mM}) \\
\mathrm{ICP}\end{array}$ & $\begin{array}{c}\mathrm{K} \\
(\mathrm{mM}) \\
\mathrm{ICP}\end{array}$ & $\begin{array}{c}B \\
(M M) \\
I C P\end{array}$ & $\begin{array}{c}\mathrm{Ba} \\
(\mathrm{MM}) \\
\mathrm{CM}\end{array}$ & $\begin{array}{c}\mathrm{Fe} \\
(\mu \mathrm{M}) \\
\mathrm{ICP}\end{array}$ & $\begin{array}{l}\mathrm{Li} \\
(\mu \mathrm{M}) \\
\mathrm{ICP}\end{array}$ & $\begin{array}{c}\mathrm{Mn} \\
(\mathrm{MM}) \\
\mathrm{ICP}\end{array}$ & $\begin{array}{c}\mathrm{Si} \\
(\mathrm{MM}) \\
\mathrm{ICP}\end{array}$ & $\begin{array}{c}\mathrm{Sr} \\
(\mathrm{MM}) \\
\mathrm{ICP}\end{array}$ & 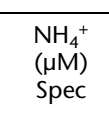 & $\begin{array}{l}\mathrm{PO}^{3^{3-}} \\
\left(\mathrm{HM}^{2} \mathrm{M}\right. \\
\text { Specc }\end{array}$ \\
\hline $\begin{array}{l}346-\mathrm{U} 1340 \mathrm{~A}-\mathrm{A} \\
1 \mathrm{H}-10-5\end{array}$ & & & & & & & & & & & & & & & & & & & & & & \\
\hline $\begin{array}{l}1 \mathrm{H}-1,0-5 \\
1 \mathrm{H}-1,145-150\end{array}$ & $\begin{array}{l}0 \\
1.45\end{array}$ & ML & $\begin{array}{l}2.40 \\
5.85\end{array}$ & $\begin{array}{l}7.48 \\
7.32 \\
-\end{array}$ & $\begin{array}{l}35.500 \\
35.00\end{array}$ & $\begin{array}{l}544.2 \\
541.6\end{array}$ & $\begin{array}{l}545.0 \\
543.0\end{array}$ & $\begin{array}{l}28.4 \\
26.4\end{array}$ & $\begin{array}{l}0.83 \\
0.83\end{array}$ & $\begin{array}{l}{ }_{468.37} \\
46297\end{array}$ & $\begin{array}{l}9.73 \\
9.51\end{array}$ & $\begin{array}{l}52.03 \\
49.57\end{array}$ & $\begin{array}{l}10.49 \\
12.02\end{array}$ & $\begin{array}{l}\begin{array}{l}410.04 \\
55029\end{array} \\
5.92\end{array}$ & $\begin{array}{l}1.34 \\
718\end{array}$ & $\begin{array}{l}\text { BD } \\
186\end{array}$ & $\begin{array}{l}24.76 \\
27.26\end{array}$ & $\begin{array}{l}\mathrm{BD} \\
13.22\end{array}$ & $\begin{array}{l}175.32 \\
576.13\end{array}$ & $\begin{array}{l}88.28 \\
90.38\end{array}$ & & 2.2 \\
\hline $2 \mathrm{H}-1,145-150$ & 5.05 & IW-Sq & 11.80 & 7.34 & 35.00 & 539.2 & 534.0 & $\begin{array}{l}23.7 \\
23.7\end{array}$ & $\begin{array}{l}.032 \\
0.82\end{array}$ & 458.29 & 9.12 & $\begin{array}{l}49.23 \\
49.23\end{array}$ & 12.27 & 524.02 & 9.41 & $\begin{array}{l}1.00 \\
5.07\end{array}$ & 30.11 & 5.22 & 620.63 & 89.24 & 598.00 & 62.0 \\
\hline $2 \mathrm{H}-4,145-150$ & $\begin{array}{r}9.55 \\
1455\end{array}$ & IW-Sq & $\begin{array}{l}16.42 \\
0.725\end{array}$ & 7.27 & 35.00 & $\begin{array}{l}536.0 \\
50.5\end{array}$ & 534.2 & 21.1 & 0.83 & 448.70 & 8.64 & 49.65 & 11.56 & $\begin{array}{l}499.68 \\
521.07\end{array}$ & 6.50 & 3.74 & 37.50 & 1.30 & 598.03 & 94.16 & 731.00 & 80.2 \\
\hline $\begin{array}{l}3 \mathrm{H}-1,1,1 \\
3 \mathrm{H}-4,1\end{array}$ & $\begin{array}{l}14.55 \\
1905\end{array}$ & IW-Sq & $\begin{array}{l}21.25 \\
21.27\end{array}$ & 7.20 & 35.00 & $\begin{array}{l}529.5 \\
62.5\end{array}$ & S33.4 & $\begin{array}{l}19.5 \\
19.5\end{array}$ & 0.83 & ${ }_{449.08}^{440} \quad \mathrm{C}$ & 7.97 & $\begin{array}{l}49.72 \\
{ }^{9} .72\end{array}$ & 11.68 & $\begin{array}{l}531.92 \\
502\end{array}$ & 6.89 & $\begin{array}{l}3.78 \\
1.78\end{array}$ & 50.08 & BD & 651.73 & 96.75 & 1033.00 & 78.6 \\
\hline $\begin{array}{l}3 \mathrm{H}-4,145-150 \\
4 \mathrm{H}-1,145-150\end{array}$ & $\begin{array}{l}19.05 \\
24.05\end{array}$ & $\begin{array}{l}\text { IW-sq } \\
\text { IW-sq }\end{array}$ & $\begin{array}{l}23.72 \\
26.38\end{array}$ & $\begin{array}{l}7.08 \\
7.05\end{array}$ & $\begin{array}{l}34.40 \\
34.00\end{array}$ & $\begin{array}{l}5232.4 \\
532.6\end{array}$ & $\begin{array}{l}531.7 \\
536.7\end{array}$ & $\begin{array}{l}18.3 \\
17.4\end{array}$ & $\begin{array}{l}0.82 \\
0.83\end{array}$ & 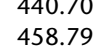 & $\begin{array}{l}7.17 \\
7.04\end{array}$ & $\begin{array}{l}48.46 \\
50.82\end{array}$ & $\begin{array}{l}71.64 \\
12.06\end{array}$ & $\begin{array}{l}588.76 \\
540.32\end{array}$ & $\begin{array}{r}71.64 \\
7.43\end{array}$ & $\begin{array}{r}12.80 \\
3.88\end{array}$ & $\begin{array}{l}60.63 \\
69.81\end{array}$ & $\begin{array}{l}\mathrm{BD} \\
0.51\end{array}$ & $\begin{array}{l}755.58 \\
705.06\end{array}$ & $\begin{array}{l}99.07 \\
98.04\end{array}$ & $\begin{array}{l}1083.300 \\
1238.00\end{array}$ & $\begin{array}{l}73.7 \\
56.7\end{array}$ \\
\hline$-4,445-150$ & 28.55 & IW-sq & & 7.09 & 35.00 & 534.4 & 528.8 & 16.3 & 0.82 & 463.75 & 6.99 & 51.02 & 12.28 & 555.38 & 6.25 & 1.25 & & 0.91 & 698.47 & 98.71 & 276.00 & 56.5 \\
\hline $5 \mathrm{H}-1,145-150$ & 33.55 & IW-sq & 31.59 & 7.12 & 34.00 & 526.8 & 536.5 & 15.8 & 0.83 & 465.95 & 6.66 & 52.36 & 12.21 & 525.10 & 8.64 & BD & 82.72 & 1.45 & 701.14 & 99.18 & 1447.00 & 50.0 \\
\hline $6 \mathrm{H}-1,145-150$ & 43.05 & IW-sq & 35.71 & 7.11 & 35.00 & 531.6 & 533.7 & 14.6 & 0.83 & 460.55 & 6.25 & 51.27 & 12.70 & 552.31 & 9.79 & $\mathrm{BD}$ & 89.53 & 2.03 & 780.10 & 97.12 & 1396.00 & 54.9 \\
\hline $\begin{array}{l}7 \mathrm{H}-1,1 \\
0\end{array}$ & & IW-sq & 38.35 & 7.04 & 35.00 & & 542.6 & 13.9 & 0.85 & 470.57 & 6.18 & 51.41 & 12.71 & 591.15 & 9.05 & BD & 91.97 & 1.72 & 827.62 & 94.07 & 1412.00 & 46.5 \\
\hline $\begin{array}{l}8 \mathrm{H}-1,145-150 \\
9 \mathrm{H}-1,145-150\end{array}$ & $\begin{array}{l}62.05 \\
71.55\end{array}$ & $\begin{array}{l}\text { IW-Sq } \\
\text { IW-Sg }\end{array}$ & $\begin{array}{l}40.01 \\
41.25\end{array}$ & $\begin{array}{l}7.21 \\
7.03\end{array}$ & $\begin{array}{l}35.00 \\
33500\end{array}$ & $\begin{array}{l}543.1 \\
536.6\end{array}$ & $\begin{array}{l}536.3 \\
566\end{array}$ & $\begin{array}{l}13.4 \\
1.34\end{array}$ & $\begin{array}{l}0.83 \\
0.84\end{array}$ & $\begin{array}{l}{ }_{466.66}^{469} \\
46971\end{array}$ & $\begin{array}{l}7.06 \\
7.49\end{array}$ & $\begin{array}{r}53.62 \\
5508\end{array}$ & $\begin{array}{l}11.41 \\
12.83\end{array}$ & $\begin{array}{l}504.94 \\
52777\end{array}$ & $\begin{array}{l}6.95 \\
773\end{array}$ & $\begin{array}{l}\text { BD } \\
B D\end{array}$ & $\begin{array}{r}95.48 \\
10020\end{array}$ & 2.16 & $\begin{array}{l}823.72 \\
811.42\end{array}$ & $\begin{array}{l}94.82 \\
07.49\end{array}$ & $\begin{array}{l}1412.00 \\
134100\end{array}$ & ${ }^{48.3}$ \\
\hline $\begin{array}{l}\text { 9H-1, } 145-150 \\
10 \mathrm{H}-1,145-150\end{array}$ & $\begin{array}{l}71.55 \\
88.05\end{array}$ & $\begin{array}{l}\text { IW-sq } \\
\text { IW-sg }\end{array}$ & $\begin{array}{l}{ }_{41.25} \\
41.64\end{array}$ & $\begin{array}{l}7.03 \\
7.03\end{array}$ & $\begin{array}{l}35.00 \\
35.00\end{array}$ & $\begin{array}{l}537.6 \\
537.2\end{array}$ & $\begin{array}{l}536.6 \\
544.7\end{array}$ & $\begin{array}{l}13.4 \\
13.4\end{array}$ & $\begin{array}{l}0.84 \\
0.85\end{array}$ & $\begin{array}{l}469.71 \\
470.79\end{array}$ & $\begin{array}{l}7.49 \\
8.07\end{array}$ & $\begin{array}{l}52.08 \\
52.47\end{array}$ & $\begin{array}{l}12.83 \\
12.06\end{array}$ & $\begin{array}{l}527.77 \\
558.24\end{array}$ & $\begin{array}{l}7.73 \\
9.61\end{array}$ & $\begin{array}{l}\mathrm{BD} \\
\mathrm{BD}\end{array}$ & $\begin{array}{l}100.20 \\
107.68\end{array}$ & $\begin{array}{l}2.02 \\
1.83\end{array}$ & $\begin{array}{l}811.42 \\
891.68\end{array}$ & $\begin{array}{l}92.49 \\
9.15\end{array}$ & $\begin{array}{l}1341.00 \\
1360.00\end{array}$ & $\begin{array}{l}41.0 \\
37.8\end{array}$ \\
\hline $\begin{array}{l}-150 \\
H-1,1,145-150\end{array}$ & & IW-sq & & 7.05 & & & 544.0 & $\begin{array}{l}13.4 \\
13.7\end{array}$ & $\begin{array}{l}.0 .85 \\
0.85\end{array}$ & 466.51 & $0.0 \%$ & $\begin{array}{l}52.47 \\
51.61\end{array}$ & $\begin{array}{l}12.00 \\
11.85\end{array}$ & $\begin{array}{l}519.78 \\
519.48\end{array}$ & $\begin{array}{l}9.01 \\
11.96\end{array}$ & 5.14 & 123.80 & 1.03 & $\begin{array}{l}913.00 \\
913.98\end{array}$ & 96.29 & $\begin{array}{l}1500.00 \\
1410.00\end{array}$ & $\begin{array}{l}34.0 \\
24.8\end{array}$ \\
\hline $14 \mathrm{H}-1,145-150$ & 119.05 & IW-Sq & & 6.87 & 36.00 & 535.5 & 542.5 & 13.8 & 0.85 & 458.54 & $\begin{array}{lll}0.00 \\
0.02\end{array}$ & 50.77 & 11.67 & 526.06 & 7.43 & $B D$ & 144.22 & 3.82 & 1002.63 & 98.59 & 264.00 & $\begin{array}{l}28.0 \\
28.4\end{array}$ \\
\hline $16 \mathrm{H}-1,145$ & 12005 & IW-sq & 41.76 & 6.70 & 35.00 & 537.6 & 541.2 & 14.2 & 0.85 & 469.82 & 8.81 & 50.99 & 11.71 & 521.28 & 16.18 & BD & 166.02 & 1.92 & 1049.40 & 101.36 & 1162.00 & 25.4 \\
\hline $18 \mathrm{H}-1,145-150$ & 157.05 & IW-sq & 43.50 & 6.76 & 36.00 & 533.4 & 543.7 & 14.7 & 0.85 & 468.17 & 9.93 & 51.81 & 11.08 & 484.23 & 17.19 & 2.60 & 191.35 & 6.37 & 1133.11 & 108.85 & 1041.00 & 16.1 \\
\hline${ }^{20 \mathrm{H}-1,1}$ & & IW-Sq & $\begin{array}{l}43.17 \\
4317\end{array}$ & 6.83 & 36.00 & $\begin{array}{l}553.0 \\
520\end{array}$ & $\begin{array}{l}542.6 \\
54.6\end{array}$ & 15.6 & 0.85 & $\begin{array}{l}467.22 \\
467\end{array}$ & $\begin{array}{l}10.93 \\
10.93\end{array}$ & $\begin{array}{l}51.62 \\
{ }_{11.62}\end{array}$ & 10.88 & & 9.64 & 10.13 & 207.89 & 9.04 & 1145.93 & $\begin{array}{l}113.84 \\
1139\end{array}$ & 964.00 & 5.7 \\
\hline $\begin{array}{l}22 \mathrm{H}-1,145-150 \\
23 \mathrm{H}-1,145-150\end{array}$ & $\begin{array}{l}194.45 \\
203.65\end{array}$ & $\begin{array}{l}\text { IW-sq } \\
\text { IW-sg }\end{array}$ & $\begin{array}{l}{ }_{43.41}^{43.79} \\
41.79\end{array}$ & $\begin{array}{l}6.66 \\
6.61\end{array}$ & $\begin{array}{l}36.00 \\
36.00\end{array}$ & $\begin{array}{l}537.9 \\
541.3\end{array}$ & $\begin{array}{l}540.7 \\
541.6\end{array}$ & 16.2 & $\begin{array}{l}0.85 \\
0.84\end{array}$ & $\begin{array}{l}470.26 \\
466.04\end{array}$ & $\begin{array}{l}11.52 \\
11.86\end{array}$ & $\begin{array}{r}51.05 \\
5016\end{array}$ & $\begin{array}{l}10.97 \\
10.89\end{array}$ & $\begin{array}{l}488.76 \\
46784\end{array}$ & $\begin{array}{l}8.21 \\
8.87\end{array}$ & $\begin{array}{l}1.23 \\
B D\end{array}$ & $\begin{array}{l}224.90 \\
223.14\end{array}$ & $\begin{array}{l}9.01 \\
7.21\end{array}$ & $\begin{array}{l}1236.35 \\
117429\end{array}$ & $\begin{array}{l}119.59 \\
120.96\end{array}$ & $\begin{array}{l}955.00 \\
91000\end{array}$ & 8.3 \\
\hline $24 \mathrm{H}-1,145$ & & $\begin{array}{l}\text { IW } \\
\text { IW-sa }\end{array}$ & 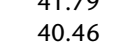 & $\begin{array}{l}0.01 \\
7.66\end{array}$ & $\begin{array}{l}30.00 \\
36.00\end{array}$ & $\begin{array}{l}54.3 .3 \\
540.1\end{array}$ & $\begin{array}{l}541.3 \\
541.3\end{array}$ & $\begin{array}{l}10.4 \\
16.9\end{array}$ & $\begin{array}{l}.084 \\
0.84\end{array}$ & 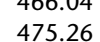 & $\begin{array}{l}11.80 \\
12.16\end{array}$ & $\begin{array}{l}50.10 \\
50.02\end{array}$ & 10.76 & 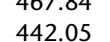 & $\begin{array}{l}.8 .87 \\
9.45\end{array}$ & 1.38 & 232.04 & $\begin{array}{l}1.21 \\
5.86\end{array}$ & $\begin{array}{l}1114.29 \\
1197.08\end{array}$ & $\begin{array}{l}124.90 \\
124.72\end{array}$ & 95.00 & 9.2 \\
\hline $25 \mathrm{H}-1,145-150$ & 222.65 & IW-sq & 38.49 & 6.59 & 36.00 & 539.5 & 540.1 & 17.9 & 0.85 & 475.77 & 12.31 & 49.71 & 10.76 & 472.38 & 6.23 & BD & 226.78 & 3.40 & 1248.77 & 124.32 & 913.00 & 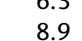 \\
\hline $26 \mathrm{H}$ & & IW-Sq & 40 & 6.70 & & 533.9 & & 17.3 & 0.84 & 471.94 & 12.67 & 13 & 10.63 & 457.81 & $17.18 \mathrm{Y} \quad \mathrm{l}$ & 2.01 & 08 & 2.11 & $1293.37 \mathrm{Cl}$ & 129.59 & 6.00 & 2.6 \\
\hline $28 \mathrm{H}-1,145-150$ & 241.55 & IW-sq & 39.99 & 6.29 & 36.00 & 539.0 & 538.6 & 17.7 & 0.84 & 468.28 & 13.28 & 48.94 & 10.09 & 452.88 & 20.64 & 66.75 & 254.04 & 2.89 & 1244.09 & 139.15 & 860.00 & 0.4 \\
\hline 346-U1340B- & & & & & & & & & & & & & & & & & & & & & & \\
\hline$m$ & 0.00 & ML & 2.40 & 7.47 & & 540.5 & 547 & 28.1 & 0.81 & & & & & 421.81 & BD & BD & 27.22 & 6.76 & 302.40 & 88.93 & 36.83 & \\
\hline $1 \mathrm{H}-1,2 \quad \mathrm{C}$ & 0.05 & IW-Rh & $\begin{array}{l}2.54 \\
2.56\end{array}$ & $\begin{array}{l}7.01 \\
7.30\end{array}$ & & $\begin{array}{l}547.1 \\
542.9\end{array}$ & & 28. & 0.8 & & & & & 502 & BD & 201.86 & 26.53 & 15 & $\begin{array}{l}781.22 \\
57110\end{array}$ & & & \\
\hline 1 & $\begin{array}{l}0.10 \\
0.15\end{array}$ & $\begin{array}{l}\text { IW-Rh } \\
\text { IW-Rh }\end{array}$ & $\begin{array}{l}2.56 \\
2.59\end{array}$ & 7.26 & & & $\begin{array}{l}442.0 \\
549.2\end{array}$ & $\begin{array}{l}28 \\
27\end{array}$ & 0.8 & & & & & & $\begin{array}{l}B D \\
B D \\
B D\end{array}$ & 51. & & $\begin{array}{l}22.15 \\
52\end{array}$ & & & & \\
\hline & 0.20 & IW-Rh & 2.66 & 7.27 & & & 550.7 & 27.8 & 0.82 & & & & & $\begin{array}{l}48 \\
50\end{array}$ & $\begin{array}{l}\mathrm{BD} \\
\mathrm{BD}\end{array}$ & 16. & & & $\begin{array}{l}460.06 \\
568.63\end{array}$ & $\begin{array}{l}89.86 \\
89.73\end{array}$ & & \\
\hline $1 \mathrm{f}$ & 0.25 & IW-Rh & 2.80 & 7.40 & & 541.2 & 547.4 & 28.1 & 0.81 & & & & & & BD & 16 & & & & & & \\
\hline & 0.30 & & 2.82 & $7+2+3$ & & 507 & & & 0 & & & & & & BD & 18. & & & & 89.86 & & \\
\hline & 0.40 & IW-Rh & $\begin{array}{l}3.10 \\
3.20\end{array}$ & 7.38 & & 540.7 & $\begin{array}{r}546.5 \\
561\end{array}$ & & 0.82 & & & & & & BD & 9.02 & & & & 90.46 & 74.64 & \\
\hline & 0.60 & 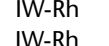 & $\begin{array}{l}3.29 \\
417\end{array}$ & $\begin{array}{l}7.48 \\
7.50\end{array}$ & & 340.4 & & & 0. & & & & & & BD & 4.15 & 26.56 & & & 89.14 & & \\
\hline & 0 & & $\begin{array}{l}4 \\
4\end{array}$ & 7 & & 543 & & & 0. & & & & & & $\begin{array}{l}\text { BD } \\
\text { BD }\end{array}$ & PR ( & & & & & & \\
\hline & & & 4 & & & 552.3 & & & & & & & & & 晨D & BD & $\begin{array}{r}28.29 \\
27\end{array}$ & & & & $\pi 19.33$ & \\
\hline & 1.53 & In & 5.54 & 7. & & 544.0 & & & & & & & & & $\begin{array}{l}\text { BD } \\
\text { BD }\end{array}$ & B & $\begin{array}{l}27.19 \\
28.33\end{array}$ & & & & 154.05 & \\
\hline & & & & & & & & & & & & & & & $\begin{array}{l}\mathrm{DU} \\
\mathrm{BD}\end{array}$ & $\mathrm{DU}$ & & & & 59 & 19400 & \\
\hline 1 & & & & & & & & & & & & & & & BD & BD & 29.08 & 1.28 & 576.36 & 92.29 & 253.00 & \\
\hline & & & 7. & 7. & & & & & 0.82 & & & & & & BD & BD & & 10. & 583.62 & 91.87 & & \\
\hline $1 \mathrm{t}$ & 3.48 & In & 8. & 7. & & & 542.0 & 25.0 & 0.8 & & & & & & BD & BD & & & & 90.71 & & \\
\hline & 413 & & 8. & 75 & & $\begin{array}{l}545.8 \\
5409\end{array}$ & 541.4 & 24.9 & 0.82 & & & & & $\begin{array}{l}427 \\
550\end{array}$ & BD & $\begin{array}{l}3.19 \\
0 D\end{array}$ & 3050 & 13 & 503.89 & 0180 & & \\
\hline & $\begin{array}{l}.4 .13 \\
4.60\end{array}$ & $\begin{array}{l}\text { II. } \\
\text { IW }\end{array}$ & 10 & 7. & & & & & 0. & & & & & 560.58 & BD & BD & 30.59 & 7.88 & 603.04 & 91.88 & & \\
\hline & 4 & & & & & 53 & & & & & & & & 571.07 & BD & BD & 8 & 6.43 & 617.33 & 93.81 & & \\
\hline & & & & & & $549 . \varepsilon$ & & & & & & & & & BD & & & & & & & \\
\hline & & & & 7. & & & & & 0 & & & & & & & B & & & & & & \\
\hline , 96-97 & 5.46 & & 1 & 7.37 & & 538.8 & & 2 & 0.83 & & & & & & $\mathrm{BD}$ & 1.12 & & & & 61 & & \\
\hline & & & & 7 & & 536.5 & & & & 46 & 9 & & & & BD & BD & & & & & & \\
\hline it & $\begin{array}{l}6.7 \\
6.8\end{array}$ & & 1. & 7. & & & & 22 & 0. & $4.2>>$ & 9. & & & & $\begin{array}{l}B D \\
0 D\end{array}$ & $B$ & & & & 年5 & & \\
\hline & 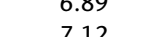 & in & 12 & 1.44 & & 54 & & 22 & & 4 & $\begin{array}{l}9.0 \\
91\end{array}$ & & & & 焉D & 要 & & & $\begin{array}{c}98 \\
56\end{array}$ & & & \\
\hline $1 \mathrm{H}-5,1$ & 7.32 & IW-Rh & 13.39 & 7.36 & & 50.0 & 544.9 & 22.8 & $\begin{array}{l}0.83 \\
0.83\end{array}$ & 499 & 8.7 & 48.8 & 11.0 & $\begin{array}{l}46700 \\
467\end{array}$ & $\mathrm{BD}$ & BD & 33.90 & 2.70 & $\begin{array}{l}653.59 \\
653.59\end{array}$ & 92.70 & & \\
\hline
\end{tabular}

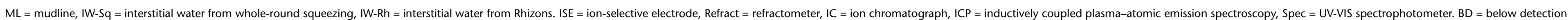


Table T11. Headspace (HS) gas concentrations, Site U1430.

\begin{tabular}{|c|c|c|c|c|c|}
\hline $\begin{array}{l}\text { Core, section, } \\
\text { interval }(\mathrm{cm})\end{array}$ & $\begin{array}{l}\text { Top depth } \\
\text { CSF-A (m) }\end{array}$ & $\begin{array}{l}\text { Sample } \\
\text { type }\end{array}$ & $\begin{array}{l}\text { Sediment } \\
\text { volume } \\
\left(\mathrm{cm}^{3}\right)\end{array}$ & $\begin{array}{c}\mathrm{CH}_{4} \\
\text { mppmv) } \\
\text { measured }\end{array}$ & $\begin{array}{c}\mathrm{CH}_{4} \\
\text { (ppmv) } \\
\text { normalized }\end{array}$ \\
\hline \multicolumn{6}{|l|}{ 346-U1430A- } \\
\hline $1 \mathrm{H}-2,0-5$ & 1.50 & $\mathrm{HS}$ & 4.0 & 0.00 & 0.00 \\
\hline $2 \mathrm{H}-2,0-5$ & 5.10 & $\mathrm{HS}$ & 2.5 & 2.10 & 4.20 \\
\hline $2 \mathrm{H}-5,0-5$ & 9.60 & $\mathrm{HS}$ & 3.0 & 1.99 & 3.32 \\
\hline $3 \mathrm{H}-5,0-5$ & 19.10 & $\mathrm{HS}$ & 3.0 & 1.95 & 3.25 \\
\hline $4 \mathrm{H}-5,0-5$ & 28.60 & $\mathrm{HS}$ & 2.5 & 2.43 & 4.86 \\
\hline $5 \mathrm{H}-2,0-5$ & 33.60 & $\mathrm{HS}$ & 3.0 & 2.38 & 3.97 \\
\hline $6 \mathrm{H}-2,0-5$ & 43.10 & $\mathrm{HS}$ & 3.0 & 2.82 & 4.70 \\
\hline $7 \mathrm{H}-2,0-5$ & 52.60 & $\mathrm{HS}$ & 3.0 & 2.88 & 4.80 \\
\hline $8 \mathrm{H}-2,0-5$ & 62.10 & $\mathrm{HS}$ & 3.0 & 5.03 & 8.38 \\
\hline $9 \mathrm{H}-2,0-5$ & 71.60 & $\mathrm{HS}$ & 2.5 & 2.60 & 5.20 \\
\hline $10 \mathrm{H}-2,0-5$ & 81.10 & $\mathrm{HS}$ & 3.0 & 5.68 & 9.47 \\
\hline $11 \mathrm{H}-2,0-5$ & 90.60 & $\mathrm{HS}$ & 3.1 & 5.32 & 8.58 \\
\hline $12 \mathrm{H}-2,0-5$ & 100.10 & $\mathrm{HS}$ & 3.0 & 5.49 & 9.15 \\
\hline $13 \mathrm{H}-2,0-5$ & 109.60 & $\mathrm{HS}$ & 2.5 & 4.26 & 8.52 \\
\hline $14 \mathrm{H}-2,0-5$ & 119.10 & $\mathrm{HS}$ & 3.0 & 5.37 & 8.95 \\
\hline $15 \mathrm{H}-2,0-5$ & 128.60 & $\mathrm{HS}$ & 3.0 & 4.59 & 7.65 \\
\hline $16 \mathrm{H}-2,0-5$ & 138.10 & $\mathrm{HS}$ & 2.4 & 4.39 & 9.15 \\
\hline $17 \mathrm{H}-2,0-5$ & 147.60 & $\mathrm{HS}$ & 3.0 & 5.40 & 9.00 \\
\hline $18 \mathrm{H}-2,0-5$ & 157.10 & $\mathrm{HS}$ & 3.0 & 4.19 & 6.98 \\
\hline $19 \mathrm{H}-1,0-5$ & 165.10 & $\mathrm{HS}$ & 3.4 & 4.61 & 6.78 \\
\hline $20 \mathrm{H}-2,0-5$ & 176.10 & $\mathrm{HS}$ & 3.6 & 4.67 & 6.49 \\
\hline $21 \mathrm{H}-2,0-5$ & 185.00 & $\mathrm{HS}$ & 3.0 & 3.70 & 6.17 \\
\hline $22 \mathrm{H}-2,0-5$ & 194.50 & $\mathrm{HS}$ & 3.0 & 4.36 & 7.27 \\
\hline $23 \mathrm{H}-2,0-5$ & 203.70 & $\mathrm{HS}$ & 3.4 & 3.48 & 5.12 \\
\hline $24 \mathrm{H}-2,0-5$ & 213.20 & HS & 3.2 & 3.64 & 5.69 \\
\hline $25 \mathrm{H}-2,0-5$ & 222.70 & $\mathrm{HS}$ & 3.0 & 3.43 & 5.72 \\
\hline $26 \mathrm{H}-2,0-5$ & 232.20 & $\mathrm{HS}$ & 3.0 & 2.91 & 4.85 \\
\hline $27 \mathrm{H}-2,0-5$ & 236.90 & $\mathrm{HS}$ & 3.2 & 2.74 & 4.28 \\
\hline $28 \mathrm{H}-2,0-5$ & 241.60 & $\mathrm{HS}$ & 3.2 & 2.54 & 3.97 \\
\hline $29 \mathrm{H}-2,0-5$ & 246.30 & $\mathrm{HS}$ & 3.0 & 1.91 & 3.18 \\
\hline
\end{tabular}


Table T12. Calcium carbonate, total carbon (TC), total organic carbon (TOC), and total nitrogen (TN) contents on interstitial water squeeze cake sediment samples, Site U1430.

\begin{tabular}{|c|c|c|c|c|c|}
\hline $\begin{array}{l}\text { Core, section, } \\
\text { interval }(\mathrm{cm})\end{array}$ & $\begin{array}{l}\text { Top depth } \\
\text { CSF-A (m) }\end{array}$ & $\begin{array}{c}\text { Calcium } \\
\text { carbonate } \\
\text { (wt\%) }\end{array}$ & $\begin{array}{c}\mathrm{TC} \\
(w t \%)\end{array}$ & $\begin{array}{l}\text { TOC } \\
\text { (wt\%) }\end{array}$ & $\begin{array}{c}\mathrm{TN} \\
(\mathrm{wt} \%)\end{array}$ \\
\hline \multicolumn{6}{|l|}{ 346-U1430A- } \\
\hline $1 \mathrm{H}-2,8-10$ & 1.58 & 13.73 & 3.12 & 1.48 & 0.20 \\
\hline $1 \mathrm{H}-3,40-41$ & 3.3 & 11.80 & 3.07 & 1.65 & 0.24 \\
\hline $2 \mathrm{H}-2,5-7$ & 5.15 & 2.02 & 3.22 & 2.98 & 0.39 \\
\hline $2 \mathrm{H}-7,26-27$ & 12.86 & 9.28 & 1.82 & 0.71 & 0.15 \\
\hline $3 \mathrm{H}-2,11-13$ & 14.71 & 11.61 & 2.84 & 1.44 & 0.24 \\
\hline $3 \mathrm{H}-7,19-20$ & 22.29 & 22.87 & 4.55 & 1.80 & 0.26 \\
\hline $4 \mathrm{H}-2,8-10$ & 24.18 & 33.37 & 5.24 & 1.24 & 0.20 \\
\hline $4 \mathrm{H}-7,41-42$ & 31.63 & 3.02 & 0.78 & 0.42 & 0.10 \\
\hline $5 \mathrm{H}-3,5-7$ & 35.15 & 2.29 & 0.82 & 0.55 & 0.16 \\
\hline $5 \mathrm{H}-7,13-14$ & 41.23 & 12.63 & 2.00 & 0.48 & 0.14 \\
\hline $6 \mathrm{H}-2,6-8$ & 43.16 & 12.53 & 2.03 & 0.53 & 0.13 \\
\hline $6 \mathrm{H}-7,16-17$ & 50.76 & 3.36 & 1.28 & 0.87 & 0.14 \\
\hline $7 \mathrm{H}-2,6-8$ & 52.66 & 2.28 & 2.03 & 1.76 & 0.25 \\
\hline $7 \mathrm{H}-7,12-13$ & 60.22 & 0.81 & 0.79 & 0.70 & 0.16 \\
\hline $8 \mathrm{H}-2,12-14$ & 62.22 & 1.12 & 0.89 & 0.76 & 0.18 \\
\hline $8 \mathrm{H}-7,40-41$ & 70 & 0.92 & & & \\
\hline $9 \mathrm{H}-2,10-12$ & 71.7 & 0.62 & 1.01 & 0.93 & 0.18 \\
\hline $10 \mathrm{H}-2,10-12$ & 81.2 & 1.07 & 3.25 & 3.12 & 0.35 \\
\hline $11 \mathrm{H}-2,14-16$ & 90.74 & 0.82 & 3.04 & 2.94 & 0.30 \\
\hline $12 \mathrm{H}-2,10-12$ & 100.2 & 0.89 & 3.49 & 3.38 & 0.34 \\
\hline $13 \mathrm{H}-2,14-16$ & 109.74 & 0.87 & 2.80 & 2.70 & 0.33 \\
\hline $14 \mathrm{H}-2,9-11$ & 119.19 & 0.59 & 3.12 & 3.05 & 0.33 \\
\hline $15 \mathrm{H}-2,12-14$ & 128.72 & 0.60 & 3.72 & 3.65 & 0.38 \\
\hline $16 \mathrm{H}-2,10-12$ & 138.2 & 0.73 & 2.95 & 2.86 & 0.32 \\
\hline $17 \mathrm{H}-2,7-9$ & 147.67 & 0.96 & 1.86 & 1.75 & 0.25 \\
\hline $18 \mathrm{H}-2,7-9$ & 157.17 & 0.72 & 3.13 & 3.04 & 0.33 \\
\hline $19 \mathrm{H}-2,10-12$ & 166.7 & 1.03 & 2.40 & 2.28 & 0.26 \\
\hline $20 \mathrm{H}-2,7-9$ & 176.17 & 0.82 & 4.28 & 4.19 & 0.39 \\
\hline $21 \mathrm{H}-2,7-9$ & 185.07 & 0.94 & 4.09 & 3.98 & 0.39 \\
\hline $22 \mathrm{H}-2,7-9$ & 194.57 & 1.27 & 4.66 & 4.50 & 0.42 \\
\hline $23 \mathrm{H}-2,6-8$ & 203.76 & 0.96 & 3.93 & 3.82 & 0.38 \\
\hline $24 \mathrm{H}-2,7-9$ & 213.27 & 0.79 & 4.17 & 4.08 & 0.37 \\
\hline $25 \mathrm{H}-2,8-10$ & 222.78 & 0.76 & 4.61 & 4.52 & 0.40 \\
\hline $26 \mathrm{H}-2,16-18$ & 232.36 & 1.96 & 4.10 & 3.86 & 0.33 \\
\hline $27 \mathrm{H}-2,9-11$ & 236.99 & 2.45 & 3.12 & 2.83 & 0.30 \\
\hline $28 \mathrm{H}-2,10-12$ & 241.7 & 2.16 & 3.36 & 3.10 & 0.31 \\
\hline $29 \mathrm{H}-1,28-30$ & 245.08 & 5.73 & 2.98 & 2.29 & 0.26 \\
\hline
\end{tabular}


Table T13. FlexIT tool core orientation data, Hole U1430A.

\begin{tabular}{lrc}
\hline Core & $\begin{array}{c}\text { Orientation } \\
\text { angle } \\
\left({ }^{\circ}\right)\end{array}$ & $\begin{array}{c}\text { Orientation } \\
\text { standard } \\
\left({ }^{\circ}\right)\end{array}$ \\
\hline $346-\mathrm{U} 1430 \mathrm{~A}-$ & & \\
$2 \mathrm{H}$ & 126.08 & 0.51 \\
$3 \mathrm{H}$ & 189.13 & 0.36 \\
$4 \mathrm{H}$ & 156.56 & 0.25 \\
$5 \mathrm{H}$ & 82.64 & 0.38 \\
$6 \mathrm{H}$ & 184.23 & 0.14 \\
$7 \mathrm{H}$ & 9.18 & 0.19 \\
$8 \mathrm{H}$ & 349.93 & 1.33 \\
$9 \mathrm{H}$ & 186.16 & 0.11 \\
$10 \mathrm{H}$ & 177.37 & 0.17 \\
$11 \mathrm{H}$ & 264.58 & 0.07 \\
$12 \mathrm{H}$ & 226.44 & 0.10 \\
$13 \mathrm{H}$ & 150.08 & 0.12 \\
$14 \mathrm{H}$ & 48.99 & 0.09 \\
$15 \mathrm{H}$ & 216.11 & 0.13 \\
$16 \mathrm{H}$ & 165.01 & 0.06 \\
$17 \mathrm{H}$ & 32.15 & 0.05 \\
$18 \mathrm{H}$ & 119.09 & 0.19 \\
$19 \mathrm{H}$ & 305.82 & 0.07 \\
$20 \mathrm{H}$ & 74.95 & 0.25 \\
$21 \mathrm{H}$ & 121.10 & 2.34 \\
$22 \mathrm{H}$ & 148.84 & 2.63 \\
$23 \mathrm{H}$ & 212.95 & 0.17 \\
$24 \mathrm{H}$ & 15.29 & 0.81 \\
$25 \mathrm{H}$ & 212.28 & 0.08 \\
\hline
\end{tabular}


Table T14. Core disturbance intervals, Site U1430. (Continued on next two pages.)

\begin{tabular}{|c|c|c|}
\hline $\begin{array}{l}\text { Core, section, } \\
\text { interval }(\mathrm{cm})\end{array}$ & Comments on disturbance & $\begin{array}{l}\text { Drilling disturbance } \\
\text { intensity }\end{array}$ \\
\hline \multicolumn{3}{|l|}{ 346-U1430A- } \\
\hline $1 \mathrm{H}-1,0-10$ & Soupy & \\
\hline $1 \mathrm{H}-1,94-104$ & Soupy & \\
\hline $2 \mathrm{H}-1,0-8$ & & Slight \\
\hline $2 \mathrm{H}-3,34-46$ & Soupy with pumice & \\
\hline $2 \mathrm{H}-3,94-100$ & Tilted ash layer & \\
\hline $2 \mathrm{H}-3,120-126$ & Ash patches & \\
\hline $2 \mathrm{H}-4,55-64$ & Soupy with pumice & \\
\hline $2 \mathrm{H}-5,113-128$ & Soupy with pumice & \\
\hline $2 \mathrm{H}-7,4-18$ & Soupy with pumice & \\
\hline $3 \mathrm{H}-1,88-123$ & Along-core gravel/sand contamination & Slight to moderate \\
\hline $3 \mathrm{H}-3,104-123$ & Soupy sediment with pumice & \\
\hline $3 \mathrm{H}-4,18-45$ & Soupy sediment with pumice & \\
\hline $3 \mathrm{H}-4,122-131$ & Slightly deformed by mixing with pumice & \\
\hline $3 \mathrm{H}-5,44-57$ & Soupy sediment with pumice & \\
\hline $3 \mathrm{H}-5,134-138$ & Soupy ash & \\
\hline $4 \mathrm{H}-1,0-14$ & Mixed sediment with pumice & \\
\hline $4 \mathrm{H}-1,65-68$ & Soupy ash & \\
\hline $4 \mathrm{H}-1,126-130$ & Soupy ash & \\
\hline $4 \mathrm{H}-2,54-72$ & Mixed sediment with pumice & \\
\hline $4 \mathrm{H}-2,83-101$ & Tilted & \\
\hline $4 \mathrm{H}-3,109-150$ & Tilted & \\
\hline $4 \mathrm{H}-4,0-145$ & Tilted & \\
\hline $4 \mathrm{H}-5,0-150$ & Tilted & \\
\hline $4 \mathrm{H}-6,0-14$ & Mixed sediments & \\
\hline $4 \mathrm{H}-6,103-112$ & Tilted & \\
\hline $4 \mathrm{H}-7,0-32$ & Tilted and mixed sediments & \\
\hline $5 \mathrm{H}-1,0-30$ & Fall-in & High \\
\hline $5 \mathrm{H}-1,72-84$ & Soupy ash & \\
\hline $5 \mathrm{H}-2,0-10$ & Pumice mixed & \\
\hline $5 \mathrm{H}-3,54-87$ & Bioturbation? Highly mixed sediments & \\
\hline $6 \mathrm{H}-1,0-19$ & Mousselike & High \\
\hline $6 \mathrm{H}-2,112-116$ & Soupy ash & \\
\hline $6 \mathrm{H}-7,0-59$ & Slightly deformed by mixing with pumice & \\
\hline $7 \mathrm{H}-1,0-23.5$ & Fall-in & High \\
\hline $7 \mathrm{H}-5,0-55$ & Slightly deformed & \\
\hline $7 \mathrm{H}-6,97-131$ & Slightly deformed & \\
\hline $8 \mathrm{H}-1,0-40$ & Slightly deformed & \\
\hline $8 \mathrm{H}-3,0-70$ & Tilted & \\
\hline $9 \mathrm{H}-1,0-26$ & Slightly deformed & \\
\hline $9 \mathrm{H}-3,18-51$ & Mixed sediments? & \\
\hline $11 \mathrm{H}-7,20-50$ & Heavy bioturbation or deformation? & \\
\hline $11 \mathrm{H}-7,52-54$ & Void & \\
\hline $13 \mathrm{H}-1,0-18$ & Soupy & Slight \\
\hline $14 \mathrm{H}-1,0-13$ & Soupy & Slight \\
\hline $15 \mathrm{H}-1,77-144$ & Wet and slightly soupy & \\
\hline $15 \mathrm{H}-1,147-150$ & Void & \\
\hline $18 \mathrm{H}-1,0-5$ & Fall-in & Slight \\
\hline $18 \mathrm{H}-3,57-58$ & Crack & High \\
\hline $18 \mathrm{H}-3,145-150$ & Void & \\
\hline $18 \mathrm{H}-5,110-112$ & Void & \\
\hline $18 \mathrm{H}-7,0-76$ & Sediment completely messed up & Destroyed \\
\hline $19 \mathrm{H}-3,130-141$ & Tilted sediment & \\
\hline $20 \mathrm{H}-1,0-4$ & Fall-in & Slight \\
\hline $20 \mathrm{H}-6,97-110$ & Vertical crack & High \\
\hline $21 \mathrm{H}-7,63-68$ & & Slight to moderate \\
\hline $21 \mathrm{H}-\mathrm{CC}, 0-25$ & & Slight \\
\hline $22 \mathrm{H}-1,0-10$ & Fall-in & High \\
\hline $22 \mathrm{H}-2,70-92$ & Deformed & \\
\hline $22 \mathrm{H}-3,139-150$ & & Moderate \\
\hline $22 \mathrm{H}-4,95-115$ & Deformed & \\
\hline $22 \mathrm{H}-\mathrm{CC}, 0-20$ & & Slight \\
\hline $23 \mathrm{H}-1,0-10$ & Fall-in & Moderate \\
\hline $23 \mathrm{H}-7,38-52$ & Crack & Moderate to high \\
\hline $25 \mathrm{H}-1,0-20$ & Deformed & \\
\hline $27 \mathrm{H}-1,0-20$ & Deformed & \\
\hline $28 \mathrm{H}-3,0-120$ & Suck in & High \\
\hline $28 \mathrm{H}-4,0-49$ & Suck in & High \\
\hline $28 \mathrm{H}-\mathrm{CC}, 0-30$ & Suck in & High \\
\hline
\end{tabular}


Table T14 (continued). (Continued on next page.)

\begin{tabular}{|c|c|c|}
\hline $\begin{array}{l}\text { Core, section, } \\
\text { interval }(\mathrm{cm})\end{array}$ & Comments on disturbance & $\begin{array}{l}\text { Drilling disturbance } \\
\text { intensity }\end{array}$ \\
\hline $29 \mathrm{H}-1,0-150$ & Suck in & High \\
\hline $29 \mathrm{H}-2,0-150$ & Suck in & High \\
\hline $29 \mathrm{H}-3,0-150$ & Suck in & High \\
\hline $29 \mathrm{H}-\mathrm{CC}, 0-25$ & Suck in & High \\
\hline $30 X-C C, 0-21$ & Destroyed & \\
\hline $31 X-C C, 0-26$ & Destroyed & \\
\hline $32 X-C C, 43-50$ & Destroyed & \\
\hline \multicolumn{3}{|l|}{ 346-U1430B- } \\
\hline $1 \mathrm{H}-1,0-10$ & Soupy & \\
\hline $1 \mathrm{H}-3,62-78$ & Along-core gravel/sand contamination & Slight \\
\hline $1 \mathrm{H}-4,88-97$ & Along-core gravel/sand contamination & Slight \\
\hline $1 \mathrm{H}-5,130-139$ & Along-core gravel/sand contamination & Slight \\
\hline $2 \mathrm{H}-1,0-5$ & Soupy & \\
\hline $2 \mathrm{H}-1,65-79$ & Pumice & \\
\hline $2 \mathrm{H}-2,130-141$ & Pumice & \\
\hline $2 \mathrm{H}-5,60-95$ & Along-core gravel/sand contamination & Slight \\
\hline $2 \mathrm{H}-6,47-52$ & Deformed & \\
\hline $3 \mathrm{H}-1,0-7$ & Soupy & \\
\hline $3 \mathrm{H}-1,51-73$ & Pumice & \\
\hline $3 \mathrm{H}-2,0-20$ & Soupy & \\
\hline $3 \mathrm{H}-2,74-95$ & Pumice contamination & \\
\hline $3 \mathrm{H}-4,120-136$ & Pumice contamination & \\
\hline $3 \mathrm{H}-5,0-83$ & Pumice contamination & \\
\hline $3 \mathrm{H}-6,70-85$ & Pumice contamination & \\
\hline $4 \mathrm{H}-1,0-149$ & Tilted & \\
\hline $4 \mathrm{H}-2,0-149$ & Tilted & \\
\hline $4 \mathrm{H}-2,108-138$ & Along-core gravel/sand contamination & Slight \\
\hline $4 \mathrm{H}-3,0-150$ & Tilted & \\
\hline $4 \mathrm{H}-3,25-30$ & Soupy & \\
\hline $4 \mathrm{H}-4,0-68$ & Tilted & \\
\hline $4 \mathrm{H}-5,0-22$ & Soupy and ash patches & \\
\hline $4 \mathrm{H}-5,130-150$ & Soupy & \\
\hline $5 \mathrm{H}-6,76-85$ & Soupy pumice & \\
\hline $6 \mathrm{H}-4,0-110$ & Mixed with pumice & \\
\hline $6 \mathrm{H}-4,139-151$ & Mixed with pumice & \\
\hline $8 \mathrm{H}-2,0-150$ & Suck in & Slight \\
\hline $16 \mathrm{H}-4,67-69$ & Ash wash out? & \\
\hline $17 \mathrm{H}-1,0-20$ & Deformed & \\
\hline $18 \mathrm{H}-6,120-150$ & Suck in & \\
\hline $18 \mathrm{H}-7,0-62$ & Suck in & \\
\hline $18 \mathrm{H}-\mathrm{CC}, 0-12$ & Suck in & \\
\hline $19 \mathrm{H}-1,0-5$ & Disturbed & \\
\hline $20 \mathrm{H}-1,0-7$ & Disturbed & \\
\hline $20 \mathrm{H}-6,18-27$ & Deformed & High \\
\hline $21 \mathrm{H}-7,0-65$ & Liner disturbed & High \\
\hline $25 \mathrm{H}-5,70-111$ & Flow-in & Severe \\
\hline $25 \mathrm{H}-6,0-53$ & Flow-in & \\
\hline $27 \mathrm{H}-4,53-63$ & Void & \\
\hline $28 \mathrm{H}-1,34-53$ & Disturbed & \\
\hline $28 \mathrm{H}-2,0-150$ & & Severe \\
\hline $28 \mathrm{H}-3,0-79$ & & Severe \\
\hline $28 \mathrm{H}-4,0-86$ & & Severe \\
\hline $30 X-C C, 0-8$ & & Severe \\
\hline $30 X-C C, 8-69$ & & Moderate \\
\hline $31 X-1,0-38$ & Washed gravel & Severe \\
\hline $32 X-1,0-12$ & Fall-in & Moderate \\
\hline $33 X-1,0-10$ & Fall-in & Moderate to high \\
\hline $33 X-1,84-99$ & Washed gravel & \\
\hline $36 X-1,28-61$ & Slurry & Moderate to high \\
\hline $37 \mathrm{H}-1,0-80$ & Soupy and gravel & \\
\hline $37 \mathrm{H}-1,82-92$ & Slurry & Moderate to high \\
\hline \multicolumn{3}{|l|}{ 346-U1430C- } \\
\hline $1 \mathrm{H}-1,0-94$ & Soupy & \\
\hline $1 \mathrm{H}-2,55-66$ & Soupy & \\
\hline $1 \mathrm{H}-3,53-81$ & Along-core gravel/sand contamination & \\
\hline $2 \mathrm{H}-1,9-40$ & Soupy & \\
\hline $2 \mathrm{H}-2,74-92$ & Along-core gravel/sand contamination & \\
\hline $2 \mathrm{H}-2,141-150$ & Slightly tilted & \\
\hline $2 \mathrm{H}-3,12-27$ & Deformed & \\
\hline
\end{tabular}


Table T14 (continued).

\begin{tabular}{|c|c|c|}
\hline $\begin{array}{l}\text { Core, section, } \\
\text { interval }(\mathrm{cm})\end{array}$ & Comments on disturbance & $\begin{array}{l}\text { Drilling disturbance } \\
\text { intensity }\end{array}$ \\
\hline $2 \mathrm{H}-3,104-119$ & Pumice and along-core gravel/sand contamination & \\
\hline $2 \mathrm{H}-4,0-2$ & & Slight \\
\hline $2 \mathrm{H}-4,42-55$ & Pumice slightly disturbed the sediments & \\
\hline $2 \mathrm{H}-5,20-33$ & Pumice and along-core gravel/sand contamination & \\
\hline $2 \mathrm{H}-6,47-58$ & Soupy and coarse sand & \\
\hline $3 \mathrm{H}-3,15-22$ & Pumice and along-core gravel/sand contamination & \\
\hline $3 \mathrm{H}-3,58-118$ & Disturbed by mixing coarse gravel/sand & \\
\hline $3 \mathrm{H}-4,0-22$ & Disturbed by mixing coarse gravel/sand & \\
\hline $3 \mathrm{H}-4,62-63$ & Dropstone? & \\
\hline $3 \mathrm{H}-4,91-101$ & Pumice and along-core gravel/sand contamination & \\
\hline $3 \mathrm{H}-5,16-30$ & Soupy and mixed with ash patches & \\
\hline $3 \mathrm{H}-5,40-42$ & Soupy ash & \\
\hline $4 \mathrm{H}-1,0-18$ & Mixed with pumice & Moderate to high \\
\hline $4 \mathrm{H}-1,83-91$ & Mixed with pumice & \\
\hline $4 \mathrm{H}-2,24-39$ & Mixed with pumice & \\
\hline $4 \mathrm{H}-3,84-110$ & Mixed with pumice & \\
\hline $4 \mathrm{H}-3,128-133$ & Stretched & \\
\hline $4 \mathrm{H}-5,0-35$ & Pumice & \\
\hline $4 \mathrm{H}-5,112-146$ & Soupy ash contained & \\
\hline $4 \mathrm{H}-6,24-32$ & Soupy ash & \\
\hline $4 \mathrm{H}-6,48-66$ & Pumice contained & \\
\hline $4 \mathrm{H}-6,102-105$ & Pumice contained & \\
\hline $4 \mathrm{H}-7,46-59$ & Tilted & \\
\hline $5 \mathrm{H}-1,17-129$ & Tilted & \\
\hline $5 \mathrm{H}-2,0-18$ & Mixed with pumice & \\
\hline $5 \mathrm{H}-2,91-114$ & Mixed with ash patches & \\
\hline $5 \mathrm{H}-2,138-151$ & Mixed with ash patches & \\
\hline $5 \mathrm{H}-3,26-85$ & Mixed with pumice and deformed & \\
\hline $5 \mathrm{H}-3,122-143$ & Mixed with pumice and deformed & \\
\hline $5 \mathrm{H}-4,0-150$ & Tilted & \\
\hline $5 \mathrm{H}-5,0-59$ & Tilted & \\
\hline $5 \mathrm{H}-6,37-58$ & Tilted & \\
\hline $6 \mathrm{H}-2,115-145$ & Soupy and mixed with pumice & \\
\hline $6 \mathrm{H}-3,0-11$ & Fault? & \\
\hline $6 \mathrm{H}-6,0-118$ & Mixed with pumice & \\
\hline $8 \mathrm{H}-2,0-46$ & Soupy & \\
\hline $9 \mathrm{H}-1,0-111$ & Mixed & \\
\hline $9 \mathrm{H}-6,119-120$ & Microfault? & \\
\hline $13 \mathrm{H}-3,105-109$ & Washed out? & \\
\hline $14 \mathrm{H}-1,0-12$ & Fall-in & \\
\hline $17 \mathrm{H}-1,0-10$ & Fall-in & \\
\hline $19 \mathrm{H}-3,113-120$ & Void & \\
\hline $20 \mathrm{H}-1,0-7$ & Mixed & \\
\hline $21 \mathrm{H}-5,48-60$ & Microfault & \\
\hline $22 \mathrm{H}-3,120-128$ & Microfault & \\
\hline $22 \mathrm{H}-5,35-44$ & Microfault & \\
\hline $22 \mathrm{H}-5,48-60$ & Microfault & \\
\hline $22 \mathrm{H}-7,35-40$ & Microfault & \\
\hline $25 \mathrm{H}-4,68-72$ & Microfault & \\
\hline $28 \mathrm{H}-1,0-27$ & Fall-in and microfault & High \\
\hline $28 \mathrm{H}-3,53-59$ & Microfault & \\
\hline $30 \mathrm{H}-3,66-74$ & Nodule & \\
\hline $31 \mathrm{H}-1,0-8$ & Disturbed & \\
\hline $32 \mathrm{H}-1,85-150$ & Flow-in & High \\
\hline $32 \mathrm{H}-2,0-150$ & Flow-in & High \\
\hline $32 \mathrm{H}-3,0-84$ & Flow-in & High \\
\hline $32 \mathrm{H}-\mathrm{CC}, 0-15$ & Flow-in & High \\
\hline $33 \mathrm{H}-1,0-30$ & Sand mixed sediment & \\
\hline $33 \mathrm{H}-1,31-77$ & Ash & \\
\hline
\end{tabular}


Table T15. NRM inclination, declination, and intensity data after $20 \mathrm{mT}$ peak field AF demagnetization, Site U1430.

\begin{tabular}{|c|c|c|c|c|c|}
\hline $\begin{array}{l}\text { Core, section } \\
\text { interval }(\mathrm{cm})\end{array}$ & $\begin{array}{c}\text { Depth } \\
\text { CSF-A (m) }\end{array}$ & $\begin{array}{c}\text { Inclination } \\
\left({ }^{\circ}\right)\end{array}$ & $\begin{array}{l}\text { Declination } \\
\left({ }^{\circ}\right)\end{array}$ & $\begin{array}{l}\text { FlexIT-corrected } \\
\text { declination } \\
\left(^{\circ}\right)\end{array}$ & $\begin{array}{l}\text { Intensity } \\
(\mathrm{A} / \mathrm{m})\end{array}$ \\
\hline \multicolumn{6}{|l|}{ 346-U1430A- } \\
\hline $1 \mathrm{H}-1$ & 0 & & & & \\
\hline $1 \mathrm{H}-1,5$ & 0.05 & & & & \\
\hline $1 \mathrm{H}-1,10$ & 0.1 & & & & \\
\hline $1 \mathrm{H}-1,15$ & 0.15 & 50.5 & 136.8 & & 0.012461 \\
\hline $1 \mathrm{H}-1,20$ & 0.2 & 50.4 & 134.5 & & 0.014582 \\
\hline $1 \mathrm{H}-1,25$ & 0.25 & 52.6 & 136.5 & & 0.011383 \\
\hline $1 \mathrm{H}-1,30$ & 0.3 & 59.7 & 152.8 & & 0.00631 \\
\hline $1 \mathrm{H}-1,35$ & 0.35 & 75.8 & 242 & & 0.00276 \\
\hline $1 \mathrm{H}-1,40$ & 0.4 & 65.3 & 24 & & 0.00146 \\
\hline $1 \mathrm{H}-1,45$ & 0.45 & 56.5 & 110.5 & & 0.00168 \\
\hline $1 \mathrm{H}-1,50$ & 0.5 & 64.5 & 152 & & 0.00113 \\
\hline $1 \mathrm{H}-1,55$ & 0.55 & 58.6 & 144.4 & & 0.00108 \\
\hline $1 \mathrm{H}-1,60$ & 0.6 & 49.8 & 145.9 & & 0.00118 \\
\hline $1 \mathrm{H}-1,65$ & 0.65 & 60.5 & 152.4 & & 0.00104 \\
\hline $1 \mathrm{H}-1,70$ & 0.7 & 65 & 147.2 & & 0.00114 \\
\hline $1 \mathrm{H}-1,75$ & 0.75 & 65.1 & 147.1 & & 0.00134 \\
\hline $1 \mathrm{H}-1,80$ & 0.8 & 61.3 & 146.6 & & 0.00173 \\
\hline $1 \mathrm{H}-1,85$ & 0.85 & 60 & 141.9 & & 0.00209 \\
\hline $1 \mathrm{H}-1,90$ & 0.9 & 56.8 & 137.6 & & 0.00282 \\
\hline $1 \mathrm{H}-1,95$ & 0.95 & & & & \\
\hline $1 \mathrm{H}-1,100$ & 1 & & & & \\
\hline $1 \mathrm{H}-1,105$ & 1.05 & 58.4 & 146.2 & & 0.00153 \\
\hline $1 \mathrm{H}-1,110$ & 1.1 & 78.7 & 151.9 & & 0.00118 \\
\hline $1 \mathrm{H}-1,115$ & 1.15 & 76.1 & 321.6 & & 0.00131 \\
\hline $1 \mathrm{H}-1,120$ & 1.2 & 77.5 & 296.7 & & 0.00325 \\
\hline $1 \mathrm{H}-1,125$ & 1.25 & 64.1 & 144 & & 0.011022 \\
\hline $1 \mathrm{H}-1,130$ & 1.3 & 50.5 & 139.7 & & 0.025871 \\
\hline $1 \mathrm{H}-1,135$ & 1.35 & 48.3 & 145.7 & & 0.031161 \\
\hline $1 \mathrm{H}-1,140$ & 1.4 & & & & \\
\hline $1 \mathrm{H}-1,145$ & 1.45 & & & & \\
\hline $1 \mathrm{H}-1,150$ & 1.5 & & & & \\
\hline $1 \mathrm{H}-2$ & 1.5 & & & & \\
\hline $1 \mathrm{H}-2,5$ & 1.55 & & & & \\
\hline $1 \mathrm{H}-2,10$ & 1.6 & & & & \\
\hline $1 \mathrm{H}-2,15$ & 1.65 & 64.8 & 149.3 & & 0.010665 \\
\hline $1 \mathrm{H}-2,20$ & 1.7 & 69.9 & 145.2 & & 0.007 \\
\hline $1 \mathrm{H}-2,25$ & 1.75 & 61.3 & 144.2 & & 0.00744 \\
\hline $1 \mathrm{H}-2,30$ & 1.8 & 57.2 & 144.2 & & 0.00752 \\
\hline $1 \mathrm{H}-2,35$ & 1.85 & 56.3 & 142.5 & & 0.00618 \\
\hline $1 \mathrm{H}-2,40$ & 1.9 & 61.2 & 136.3 & & 0.00401 \\
\hline $1 \mathrm{H}-2,45$ & 1.95 & 68.6 & 136.4 & & 0.0026 \\
\hline $1 \mathrm{H}-2,50$ & 2 & 69.8 & 151.5 & & 0.00166 \\
\hline $1 \mathrm{H}-2,55$ & 2.05 & 69.5 & 145.9 & & 0.00192 \\
\hline $1 \mathrm{H}-2,60$ & 2.1 & 62.5 & 133.3 & & 0.00359 \\
\hline $1 \mathrm{H}-2,65$ & 2.15 & 62.1 & 138.4 & & 0.0042 \\
\hline $1 \mathrm{H}-2,70$ & 2.2 & 62.5 & 136 & & 0.00489 \\
\hline $1 \mathrm{H}-2,75$ & 2.25 & 57.9 & 133.9 & & 0.00636 \\
\hline $1 \mathrm{H}-2,80$ & 2.3 & 58.4 & 138.1 & & 0.00582 \\
\hline $1 \mathrm{H}-2,85$ & 2.35 & 60.7 & 136.3 & & 0.00468 \\
\hline $1 \mathrm{H}-2,90$ & 2.4 & 64.8 & 133.6 & & 0.00355 \\
\hline $1 \mathrm{H}-2,95$ & 2.45 & 67.8 & 135.9 & & 0.00292 \\
\hline $1 \mathrm{H}-2,100$ & 2.5 & 62.9 & 132.7 & & 0.00355 \\
\hline $1 \mathrm{H}-2,105$ & 2.55 & 61.1 & 135 & & 0.00368 \\
\hline $1 \mathrm{H}-2,110$ & 2.6 & 63.8 & 133.8 & & 0.00337 \\
\hline $1 \mathrm{H}-2,115$ & 2.65 & 61.4 & 131.2 & & 0.00358 \\
\hline $1 \mathrm{H}-2,120$ & 2.7 & 56.4 & 129.5 & & 0.00454 \\
\hline $1 \mathrm{H}-2,125$ & 2.75 & 56.7 & 134.7 & & 0.00462 \\
\hline $1 \mathrm{H}-2,130$ & 2.8 & & & & \\
\hline $1 \mathrm{H}-2,135$ & 2.85 & & & & \\
\hline $1 \mathrm{H}-2,140$ & 2.9 & & & & \\
\hline
\end{tabular}

Blank cells indicate depth levels where data were either not available (i.e., FlexIT-corrected declination data for nonoriented cores) or removed because of disturbance, voids, or measurement edge effects. Only a portion of this table appears here. The complete table is available in ASCII. 
Table T16. Polarity boundaries, Site U1430.

\begin{tabular}{|c|c|c|c|c|c|c|c|c|c|c|c|}
\hline \multicolumn{2}{|c|}{ Core, section, interval $(\mathrm{cm})$} & \multirow[b]{2}{*}{ Polarity boundary } & \multirow{2}{*}{$\begin{array}{l}\text { Age } \\
\text { (Ma) }\end{array}$} & \multicolumn{4}{|c|}{ Depth CSF-A (m) } & \multicolumn{4}{|c|}{ Depth CCSF-D (m) } \\
\hline Top & Bottom & & & Top & Bottom & Midpoint & \pm & Top & Bottom & Midpoint & \pm \\
\hline $\begin{array}{c}346-\mathrm{U} 1430 \mathrm{~A}- \\
5 \mathrm{H}-1, \sim 40\end{array}$ & $\begin{array}{c}346-\mathrm{U} 1430 \mathrm{~A}- \\
5 \mathrm{H}-2, \sim 90\end{array}$ & (B) C1n (Brunhes/Matuyama) & 0.781 & 32.5 & 34.5 & 33.5 & 1.0 & 34.5 & 36.5 & 35.5 & 1.0 \\
\hline $\begin{array}{r}346-\mathrm{U} 1430 \mathrm{~B}- \\
4 \mathrm{H}-4, \sim 120\end{array}$ & $\begin{array}{c}346-U 1430 \mathrm{~B}- \\
4 \mathrm{H}-6, \sim 20\end{array}$ & (B) C1n (Brunhes/Matuyama) & 0.781 & 33.0 & 35.0 & 34.0 & 1.0 & 34.0 & 36.0 & 35.0 & 1.0 \\
\hline $\begin{array}{r}346-\mathrm{U} 1430 \mathrm{C}- \\
5 \mathrm{H}-2, \sim 100\end{array}$ & $\begin{array}{c}346-U 1430 C- \\
-\end{array}$ & (B) C1n (Brunhes/Matuyama) & 0.781 & 35.8 & - & 37.0 & 1.2 & 52.1 & - & 53.3 & 1.2 \\
\hline
\end{tabular}

B = bottom . 
Table T17. Results from APCT-3 temperature profiles, Site U1430.

\begin{tabular}{lcccrr}
\hline Core & $\begin{array}{c}\text { Minimum } \\
\text { temperature } \\
\text { at mudline } \\
\left({ }^{\circ} \mathrm{C}\right)\end{array}$ & $\begin{array}{c}\text { Average } \\
\text { temperature } \\
\text { at mudline } \\
\left({ }^{\circ} \mathrm{C}\right)\end{array}$ & $\begin{array}{c}\text { Depth } \\
\mathrm{CSF}-\mathrm{A}(\mathrm{m})\end{array}$ & $\begin{array}{c}\text { In situ } \\
\text { temperature } \\
\left({ }^{\circ} \mathrm{C}\right)\end{array}$ & $\begin{array}{c}\text { Thermal } \\
\text { resistance } \\
\left(\mathrm{m}^{2} \mathrm{~K} / \mathrm{W}\right)\end{array}$ \\
\hline $346-\mathrm{U} 1430 \mathrm{~A}-$ & & & & & \\
$4 \mathrm{H}$ & 0.57 & 0.79 & 32.1 & 3.36 & 33.78 \\
$7 \mathrm{H}$ & 0.49 & 0.86 & 60.6 & 5.94 & 64.52 \\
$10 \mathrm{H}$ & 0.63 & 1.07 & 89.1 & 9.01 & 95.99 \\
$13 \mathrm{H}$ & 0.64 & 0.97 & 117.6 & 12.11 & 128.23 \\
\multicolumn{1}{c}{ Average: } & 0.58 & 0.92 & & & \\
\hline
\end{tabular}

In situ temperatures were determined using TP-Fit software by Martin Heesemann. Thermal resistance was calculated from thermal conductivity data (see "Physical properties") corrected for in situ conditions (see "Downhole measurements" in the "Methods" chapter [Tada et al., 2015b]).

Table T18. Vertical offsets required to correlate specific features among cores from adjacent holes, Site U1430.

\begin{tabular}{|c|c|c|c|c|c|c|c|c|}
\hline Core & $\begin{array}{l}\text { Vertical } \\
\text { offset }(m)\end{array}$ & $\mathrm{Y} / \mathrm{N}$ & Core & $\begin{array}{c}\text { Vertical } \\
\text { offset (m) }\end{array}$ & $\mathrm{Y} / \mathrm{N}$ & Core & $\begin{array}{c}\text { Vertical } \\
\text { offset }(m)\end{array}$ & $\mathrm{Y} / \mathrm{N}$ \\
\hline 346-U1430A- & & & 346-U1430B- & & & 346-U1430C- & & \\
\hline $1 \mathrm{H}$ & 0.21 & Y & $1 \mathrm{H}$ & 0.00 & $\mathrm{~N}$ & $1 \mathrm{H}$ & 0.11 & $Y$ \\
\hline $2 \mathrm{H}$ & 0.36 & Y & $2 \mathrm{H}$ & 0.02 & $Y$ & $2 \mathrm{H}$ & 0.23 & $Y$ \\
\hline $3 \mathrm{H}$ & 1.00 & $Y$ & $3 \mathrm{H}$ & 0.44 & $Y$ & $3 \mathrm{H}$ & 0.84 & $\mathrm{Y}$ \\
\hline $4 \mathrm{H}$ & 1.81 & Y & $4 \mathrm{H}$ & 0.97 & $Y$ & $4 \mathrm{H}$ & 0.87 & $Y$ \\
\hline $5 \mathrm{H}$ & 1.95 & $Y$ & $5 \mathrm{H}$ & 1.58 & $Y$ & $5 \mathrm{H}$ & 0.77 & $Y$ \\
\hline $6 \mathrm{H}$ & 2.37 & Y & $6 \mathrm{H}$ & 2.01 & $Y$ & $6 \mathrm{H}$ & 3.10 & $Y$ \\
\hline $7 \mathrm{H}$ & 2.92 & $Y$ & $7 \mathrm{H}$ & 2.44 & $Y$ & $7 \mathrm{H}$ & 4.14 & $\mathrm{Y}$ \\
\hline $8 \mathrm{H}$ & 3.44 & $Y$ & $8 \mathrm{H}$ & 3.02 & $Y$ & $8 \mathrm{H}$ & 4.65 & $\mathrm{Y}$ \\
\hline $9 \mathrm{H}$ & 3.55 & Y & $9 \mathrm{H}$ & 3.31 & $Y$ & $9 \mathrm{H}$ & 5.06 & $Y$ \\
\hline $10 \mathrm{H}$ & 4.45 & $\mathrm{Y}$ & $10 \mathrm{H}$ & 4.23 & $Y$ & $10 \mathrm{H}$ & 5.96 & $Y$ \\
\hline $11 \mathrm{H}$ & 5.07 & $\mathrm{Y}$ & $11 \mathrm{H}$ & 4.74 & $Y$ & $11 \mathrm{H}$ & 6.76 & $Y$ \\
\hline $12 \mathrm{H}$ & 5.78 & $\mathrm{Y}$ & $12 \mathrm{H}$ & 5.3 & $Y$ & $12 \mathrm{H}$ & 7.47 & $\mathrm{Y}$ \\
\hline $13 \mathrm{H}$ & 6.54 & $\mathrm{Y}$ & $13 \mathrm{H}$ & 5.96 & $Y$ & $13 \mathrm{H}$ & 8.12 & $\mathrm{Y}$ \\
\hline $14 \mathrm{H}$ & 6.95 & $\mathrm{Y}$ & $14 \mathrm{H}$ & 6.59 & $Y$ & $14 \mathrm{H}$ & 8.79 & $\mathrm{Y}$ \\
\hline $15 \mathrm{H}$ & 7.37 & $Y$ & $15 \mathrm{H}$ & 7.16 & $Y$ & $15 \mathrm{H}$ & 9.06 & $\mathrm{Y}$ \\
\hline $16 \mathrm{H}$ & 8.14 & Y & $16 \mathrm{H}$ & 8.82 & $Y$ & $16 \mathrm{H}$ & 10.48 & $Y$ \\
\hline $17 \mathrm{H}$ & 10.01 & $Y$ & $17 \mathrm{H}$ & 9.15 & $Y$ & $17 \mathrm{H}$ & 11.37 & $Y$ \\
\hline $18 \mathrm{H}$ & 10.15 & Y & $18 \mathrm{H}$ & 9.92 & $Y$ & $18 \mathrm{H}$ & 11.40 & $Y$ \\
\hline $19 \mathrm{H}$ & 10.64 & $\mathrm{Y}$ & $19 \mathrm{H}$ & 10.05 & $Y$ & $19 \mathrm{H}$ & 11.70 & $\mathrm{Y}$ \\
\hline $20 \mathrm{H}$ & 11.28 & Y & $20 \mathrm{H}$ & 10.75 & $Y$ & $20 \mathrm{H}$ & 12.33 & $Y$ \\
\hline $21 \mathrm{H}$ & 11.97 & $Y$ & $21 \mathrm{H}$ & 12.74 & $Y$ & $21 \mathrm{H}$ & 13.37 & $\mathrm{Y}$ \\
\hline $22 \mathrm{H}$ & 13.21 & $Y$ & $22 \mathrm{H}$ & 12.78 & $\mathrm{Y}$ & $22 \mathrm{H}$ & 14.88 & $\mathrm{Y}$ \\
\hline $23 \mathrm{H}$ & 13.53 & Y & $23 \mathrm{H}$ & 13.21 & $Y$ & $23 \mathrm{H}$ & 14.99 & $Y$ \\
\hline $24 \mathrm{H}$ & 13.93 & Y & $24 \mathrm{H}$ & 12.99 & $Y$ & $24 \mathrm{H}$ & 15.21 & $Y$ \\
\hline $25 \mathrm{H}$ & 13.71 & Y & $25 \mathrm{H}$ & 12.90 & $Y$ & $25 \mathrm{H}$ & 14.85 & $Y$ \\
\hline $26 \mathrm{H}$ & 14.60 & $Y$ & $26 \mathrm{H}$ & 13.19 & $\mathrm{Y}$ & $26 X$ & 15.46 & $Y$ \\
\hline $27 \mathrm{H}$ & 14.61 & $Y$ & $27 \mathrm{H}$ & 13.60 & $Y$ & $27 X$ & 15.46 & $\mathrm{~N}$ \\
\hline $28 \mathrm{H}$ & 15.19 & $Y$ & $28 \mathrm{H}$ & 16.34 & $Y$ & $28 \mathrm{H}$ & 15.58 & $\mathrm{Y}$ \\
\hline $29 \mathrm{H}$ & 15.13 & Y & $29 x$ & 16.34 & $\mathrm{~N}$ & $29 \mathrm{H}$ & 15.89 & $Y$ \\
\hline $30 x$ & 15.13 & $\mathrm{~N}$ & $30 x$ & 16.34 & $\mathrm{~N}$ & $30 \mathrm{H}$ & 16.29 & $Y$ \\
\hline $31 x$ & 15.13 & $\mathrm{~N}$ & $31 x$ & 16.34 & $\mathrm{~N}$ & $31 \mathrm{H}$ & 16.29 & $\mathrm{~N}$ \\
\hline \multirow[t]{6}{*}{$32 x$} & 15.13 & $\mathrm{~N}$ & $32 x$ & 16.34 & $\mathrm{~N}$ & $32 \mathrm{H}$ & 16.78 & $Y$ \\
\hline & & & $33 x$ & 16.34 & $\mathrm{~N}$ & $33 \mathrm{H}$ & 16.78 & $\mathrm{~N}$ \\
\hline & & & $34 X$ & 16.34 & $\mathrm{~N}$ & $34 \mathrm{H}$ & 16.78 & $\mathrm{~N}$ \\
\hline & & & $35 x$ & 16.34 & $\mathrm{~N}$ & & & \\
\hline & & & $36 x$ & 16.34 & $\mathrm{~N}$ & & & \\
\hline & & & $37 \mathrm{H}$ & 16.34 & $\mathrm{~N}$ & & & \\
\hline
\end{tabular}


Table T19. Splice intervals, Site U1430.

\begin{tabular}{|c|c|c|c|c|c|c|c|c|c|}
\hline Hole, core, section & $\begin{array}{l}\text { Depth in } \\
\text { section }(\mathrm{cm})\end{array}$ & $\begin{array}{l}\text { Depth } \\
\text { CSF-A (m) }\end{array}$ & $\begin{array}{c}\text { Depth } \\
\text { CCSF-D }(\mathrm{m})\end{array}$ & & Hole, core, section & $\begin{array}{l}\text { Depth in } \\
\text { section }(\mathrm{cm})\end{array}$ & $\begin{array}{l}\text { Depth } \\
\text { CSF-A (m) }\end{array}$ & $\begin{array}{l}\text { Depth } \\
\text { CCSF-D (m) }\end{array}$ & $\begin{array}{c}\text { Data used } \\
\text { to tie }\end{array}$ \\
\hline $346-$ & & & & & $346-$ & & & & \\
\hline U1430B-1H-1 & 0.00 & 0.00 & 0.00 & Tie to & U1430B-1H-6 & 11.84 & 7.62 & 7.62 & Blue \\
\hline U1430A-2H-3 & 65.8 & 7.26 & 7.62 & Tie to & U1430A-2H-4 & 64.38 & 8.74 & 9.10 & Blue \\
\hline U1430B-2H-1 & 78.79 & 9.09 & 9.10 & Tie to & U1430B-2H-6 & 111.82 & 16.92 & 16.93 & Blue \\
\hline U1430A-3H-2 & 133.19 & 15.93 & 16.93 & Tie to & U1430A-3H-4 & 38.94 & 17.99 & 18.99 & Blue \\
\hline U1430B-3H-1 & 74.99 & 18.55 & 18.99 & Tie to & U1430B-3H-6 & 129.43 & 26.59 & 27.04 & Blue \\
\hline U1430A-4H-2 & 112.15 & 25.22 & 27.04 & Tie to & U1430A-4H-4 & 11.57 & 27.22 & 29.03 & Blue \\
\hline U1430B-4H-1 & 75.74 & 28.06 & 29.03 & Tie to & U1430B-4H-6 & 94.79 & 35.75 & 36.72 & Blue \\
\hline U1430A-5H-2 & 116.89 & 34.77 & 36.72 & Tie to & U1430A-5H-4 & 41.51 & 37.02 & 38.97 & Blue \\
\hline U1430B-5H-1 & 58.58 & 37.39 & 38.97 & Tie to & U1430B-5H-7 & 10.21 & 45.71 & 47.29 & Blue \\
\hline U1430A-6H-3 & 32.74 & 44.93 & 47.29 & Tie to & U1430A-6H-4 & 124.40 & 47.34 & 49.71 & Blue \\
\hline U1430B-6H-1 & 140.23 & 47.70 & 49.71 & Tie to & U1430B-6H-6 & 96.57 & 54.77 & 56.77 & Blue \\
\hline U1430A-7H-2 & 125.01 & 53.85 & 56.77 & Tie to & U1430A-7H-4 & 41.04 & 56.01 & 58.93 & Blue \\
\hline U1430B-7H-1 & 69.37 & 56.49 & 58.93 & Tie to & U1430B-7H-6 & 73.34 & 64.03 & 66.47 & Blue \\
\hline U1430A-8H-2 & 93.38 & 63.03 & 66.47 & Tie to & U1430A-8H-6 & 7.88 & 68.18 & 71.62 & Blue \\
\hline U1430B-8H-3 & 29.79 & 68.60 & 71.62 & Tie to & U1430B-8H-6 & 92.90 & 73.73 & 76.75 & Blue \\
\hline U1430A-9H-3 & 9.69 & 73.20 & 76.75 & Tie to & U1430A-9H-4 & 132.45 & 75.92 & 79.48 & Blue \\
\hline U1430B-9H-1 & 137.05 & 76.17 & 79.48 & Tie to & U1430B-9H-6 & 12.84 & 82.43 & 85.73 & Blue \\
\hline U1430A-10H-2 & 18.81 & 81.29 & 85.73 & Tie to & U1430A-10H-4 & 111.02 & 85.21 & 89.66 & Blue \\
\hline U1430B-10H-1 & 113.12 & 85.43 & 89.66 & Tie to & U1430B-10H-6 & 13.15 & 91.93 & 96.16 & Blue \\
\hline U1430A-11H-2 & 48.61 & 91.09 & 96.16 & Tie to & U1430A-11H-5 & 9.25 & 95.19 & 100.26 & Blue \\
\hline U1430B-11H-2 & 21.88 & 95.52 & 100.26 & Tie to & U1430B-11H-6 & 108.34 & 102.38 & 107.13 & Blue \\
\hline U1430A-12H-2 & 125.26 & 101.35 & 107.13 & Tie to & U1430A-12H-4 & 107.71 & 104.18 & 109.95 & Blue \\
\hline U1430B-12H-1 & 135.57 & 104.66 & 109.95 & Tie to & U1430B-12H-6 & 86.52 & 111.67 & 116.96 & Blue \\
\hline U1430A-13H-2 & 81.85 & 110.42 & 116.96 & Tie to & U1430A-13H-4 & 48.35 & 113.08 & 119.63 & Blue \\
\hline U1430B-13H-1 & 86.90 & 113.67 & 119.63 & Tie to & U1430B-13H-6 & 144.33 & 121.74 & 127.70 & Blue \\
\hline U1430A-14H-3 & 15.17 & 120.75 & 127.70 & Tie to & U1430A-14H-5 & 6.36 & 123.66 & 130.61 & Blue \\
\hline U1430B-14H-2 & 21.84 & 124.02 & 130.61 & Tie to & U1430B-14H-6 & 108.80 & 130.89 & 137.48 & Blue \\
\hline U1430A-15H-3 & 1.74 & 130.12 & 137.48 & Tie to & U1430A-15H-4 & 136.59 & 132.97 & 140.33 & Blue \\
\hline U1430B-15H-1 & 136.73 & 133.17 & 140.33 & Tie to & U1430B-15H-5 & 137.24 & 139.17 & 146.34 & Blue \\
\hline U1430A-16H-2 & 9.22 & 138.19 & 146.34 & Tie to & U1430A-16H-5 & 50.92 & 143.11 & 151.25 & Blue \\
\hline U1430B-16H-1 & 113.26 & 142.43 & 151.25 & Tie to & U1430B-16H-7 & 0.66 & 150.31 & 159.13 & Blue \\
\hline U1430A-17H-3 & 1.66 & 149.12 & 159.13 & Tie to & U1430A-17H-4 & 11.71 & 150.74 & 160.75 & Blue \\
\hline U1430B-17H-1 & 79.94 & 151.60 & 160.75 & Tie to & U1430B-17H-7 & 5.80 & 159.86 & 169.01 & Blue \\
\hline U1430A-18H-3 & 25.74 & 158.86 & 169.01 & Tie to & U1430A-18H-4 & 127.59 & 161.38 & 171.53 & Blue \\
\hline U1430B-18H-1 & 130.35 & 161.60 & 171.53 & Tie to & U1430B-18H-7 & 18.76 & 169.49 & 179.41 & Blue \\
\hline U1430A-19H-3 & 66.57 & 168.77 & 179.41 & Tie to & U1430A-19H-5 & 39.34 & 171.49 & 182.14 & Blue \\
\hline U1430B-19H-2 & 79.15 & 172.09 & 182.14 & Tie to & U1430B-19H-7 & 7.33 & 178.37 & 188.42 & Blue \\
\hline U1430A-20H-2 & 104.12 & 177.14 & 188.42 & Tie to & U1430A-20H-4 & 32.23 & 179.42 & 190.70 & Blue \\
\hline U1430B-20H-1 & 65.41 & 179.95 & 190.70 & Tie to & U1430B-20H-6 & 99.46 & 187.79 & 198.54 & Blue \\
\hline U1430A-21H-3 & 7.32 & 186.57 & 198.54 & Tie to & U1430A-21H-6 & 11.73 & 191.12 & 203.08 & Blue \\
\hline U1430B-21H-2 & 4.50 & 190.35 & 203.08 & Tie to & U1430B-21H-7 & 16.73 & 197.95 & 210.69 & Blue \\
\hline U1430A-22H-3 & 147.35 & 197.47 & 210.69 & Tie to & U1430A-22H-6 & 49.72 & 201.00 & 214.21 & Blue \\
\hline U1430B-22H-3 & 13.52 & 201.44 & 214.21 & Tie to & U1430B-22H-6 & 142.18 & 207.22 & 220.00 & Blue \\
\hline U1430A-23H-3 & 126.45 & 206.46 & 220.00 & Tie to & U1430A-23H-6 & 15.27 & 209.85 & 223.39 & Blue \\
\hline U1430B-23H-2 & 87.37 & 210.17 & 223.39 & Tie to & U1430B-23H-6 & 114.61 & 216.45 & 229.66 & Blue \\
\hline U1430A-24H-3 & 103.22 & 215.73 & 229.66 & Tie to & U1430A-24H-6 & 19.21 & 219.39 & 233.32 & Blue \\
\hline U1430B-24H-3 & 2.64 & 220.33 & 233.32 & Tie to & U1430B-24H-6 & 77.92 & 225.58 & 238.57 & Blue \\
\hline U1430A-25H-3 & 66.12 & 224.86 & 238.57 & Tie to & U1430A-25H-7 & 28.25 & 230.00 & 243.71 & Blue \\
\hline U1430B-25H-3 & 101.34 & 230.81 & 243.71 & Tie to & U1430B-25H-5 & 34.26 & 233.14 & 246.04 & Blue \\
\hline U1430A-26H-1 & 73.72 & 231.44 & 246.04 & Tie to & U1430A-26H-4 & 3.65 & 234.96 & 249.56 & Blue \\
\hline U1430B-26H-2 & 26.61 & 236.37 & 249.56 & Tie to & U1430B-26H-4 & 42.25 & 239.14 & 252.34 & Blue \\
\hline U1430A-27H-2 & 82.39 & 237.72 & 252.34 & Tie to & U1430A-27H-3 & 120.23 & 239.60 & 254.21 & Blue \\
\hline U1430B-27H-1 & 131.47 & 240.61 & 254.21 & Tie to & U1430B-27H-3 & 42.69 & 242.73 & 256.33 & Blue \\
\hline U1430A-28H-1 & 103.96 & 241.14 & 256.33 & & U1430A-28H-3 & 76.00 & 243.88 & 259.07 & \\
\hline
\end{tabular}

Blue $=$ RGB blue datum . 
Table T20. CCSF-C depth scale, Site U1430.

\begin{tabular}{|c|c|c|c|c|c|}
\hline $\begin{array}{l}\text { Core, section, } \\
\text { interval }(\mathrm{cm})\end{array}$ & $\begin{array}{c}\text { Depth } \\
\text { CCSF-C }(\mathrm{m})\end{array}$ & $\begin{array}{l}\text { RGB } \\
\text { (blue) }\end{array}$ & Run No & $\begin{array}{c}\text { Depth } \\
\text { CSF-A (m) }\end{array}$ & Offset \\
\hline \multicolumn{6}{|l|}{ 346-U1430C- } \\
\hline $1 \mathrm{H}-1,0.01$ & 0.112628 & 30.3 & - & 0.0001 & 0.112528 \\
\hline $1 \mathrm{H}-1,0.51$ & 0.117625 & 24.9 & - & 0.0051 & 0.112528 \\
\hline $1 \mathrm{H}-1,1$ & 0.122522 & 25.4 & - & 0.01 & 0.112528 \\
\hline $1 \mathrm{H}-1,1.5$ & 0.127519 & 25.2 & - & 0.015 & 0.112528 \\
\hline $1 \mathrm{H}-1,2$ & 0.132516 & 25.4 & - & 0.02 & 0.112528 \\
\hline $1 \mathrm{H}-1,2.5$ & 0.137513 & 25.2 & - & 0.025 & 0.112528 \\
\hline $1 \mathrm{H}-1,3$ & 0.14251 & 25 & - & 0.03 & 0.112528 \\
\hline $1 \mathrm{H}-1,3.5$ & 0.147508 & 25.3 & - & 0.035 & 0.112528 \\
\hline $1 \mathrm{H}-1,4$ & 0.152505 & 24.4 & - & 0.04 & 0.112528 \\
\hline $1 \mathrm{H}-1,4.5$ & 0.157502 & 24.6 & - & 0.045 & 0.112528 \\
\hline $1 \mathrm{H}-1,5$ & 0.162499 & 23.6 & - & 0.05 & 0.112528 \\
\hline $1 \mathrm{H}-1,5.5$ & 0.167496 & 22.9 & - & 0.055 & 0.112528 \\
\hline $1 \mathrm{H}-1,6$ & 0.172493 & 23.4 & - & 0.06 & 0.112528 \\
\hline $1 \mathrm{H}-1,6.5$ & 0.17749 & 24.6 & - & 0.065 & 0.112528 \\
\hline $1 \mathrm{H}-1,7$ & 0.182487 & 25.1 & - & 0.07 & 0.112528 \\
\hline $1 \mathrm{H}-1,7.5$ & 0.187484 & 24.1 & - & 0.075 & 0.112528 \\
\hline $1 \mathrm{H}-1,8.01$ & 0.192581 & 24.5 & - & 0.0801 & 0.112528 \\
\hline $1 \mathrm{H}-1,8.51$ & 0.197578 & 24.4 & - & 0.0851 & 0.112528 \\
\hline $1 \mathrm{H}-1,9.01$ & 0.202575 & 24.8 & - & 0.0901 & 0.112528 \\
\hline $1 \mathrm{H}-1,9.51$ & 0.207572 & 24.8 & - & 0.0951 & 0.112528 \\
\hline $1 \mathrm{H}-1,10.01$ & 0.212569 & 25.4 & - & 0.1001 & 0.112528 \\
\hline $1 \mathrm{H}-1,10.51$ & 0.217567 & 25 & - & 0.1051 & 0.112528 \\
\hline $1 \mathrm{H}-1,11.01$ & 0.222564 & 25.1 & - & 0.1101 & 0.112528 \\
\hline $1 \mathrm{H}-1,11.51$ & 0.227561 & 25.7 & - & 0.1151 & 0.112528 \\
\hline $1 \mathrm{H}-1,12.01$ & 0.232558 & 26.3 & - & 0.1201 & 0.112528 \\
\hline $1 \mathrm{H}-1,12.51$ & 0.237555 & 25.8 & - & 0.1251 & 0.112528 \\
\hline $1 \mathrm{H}-1,13.01$ & 0.242552 & 24.7 & - & 0.1301 & 0.112528 \\
\hline $1 \mathrm{H}-1,13.51$ & 0.247549 & 24.1 & - & 0.1351 & 0.112528 \\
\hline $1 \mathrm{H}-1,14.01$ & 0.252546 & 20.4 & - & 0.1401 & 0.112528 \\
\hline $1 \mathrm{H}-1,14.51$ & 0.257543 & 25.1 & - & 0.1451 & 0.112528 \\
\hline $1 \mathrm{H}-1,15.01$ & 0.26254 & 27.2 & - & 0.1501 & 0.112528 \\
\hline $1 \mathrm{H}-1,15.51$ & 0.267537 & 26.6 & - & 0.1551 & 0.112528 \\
\hline $1 \mathrm{H}-1,16$ & 0.272434 & 26 & - & 0.16 & 0.112528 \\
\hline $1 \mathrm{H}-1,16.5$ & 0.277431 & 26.4 & - & 0.165 & 0.112528 \\
\hline $1 \mathrm{H}-1,17$ & 0.282429 & 26.6 & - & 0.17 & 0.112528 \\
\hline $1 \mathrm{H}-1,17.5$ & 0.287426 & 27.5 & - & 0.175 & 0.112528 \\
\hline $1 \mathrm{H}-1,18$ & 0.292423 & 27.1 & - & 0.18 & 0.112528 \\
\hline $1 \mathrm{H}-1,18.5$ & 0.29742 & 27.3 & - & 0.185 & 0.112528 \\
\hline $1 \mathrm{H}-1,19$ & 0.302417 & 27.6 & - & 0.19 & 0.112528 \\
\hline $1 \mathrm{H}-1,19.5$ & 0.307414 & 26.4 & - & 0.195 & 0.112528 \\
\hline $1 \mathrm{H}-1,20$ & 0.312411 & 27.9 & - & 0.2 & 0.112528 \\
\hline $1 \mathrm{H}-1,20.5$ & 0.317408 & 28.2 & - & 0.205 & 0.112528 \\
\hline $1 \mathrm{H}-1,21$ & 0.322405 & 28.9 & - & 0.21 & 0.112528 \\
\hline $1 \mathrm{H}-1,21.5$ & 0.327402 & 29 & - & 0.215 & 0.112528 \\
\hline $1 \mathrm{H}-1,22$ & 0.332399 & 28.5 & - & 0.22 & 0.112528 \\
\hline $1 \mathrm{H}-1,22.5$ & 0.337396 & 27.7 & - & 0.225 & 0.112528 \\
\hline $1 \mathrm{H}-1,23$ & 0.342393 & 26.6 & - & 0.23 & 0.112528 \\
\hline $1 \mathrm{H}-1,23.5$ & 0.34739 & 26.8 & - & 0.235 & 0.112528 \\
\hline $1 \mathrm{H}-1,24$ & 0.352388 & 26.7 & - & 0.24 & 0.112528 \\
\hline $1 \mathrm{H}-1,24.5$ & 0.357385 & 26.6 & - & 0.245 & 0.112528 \\
\hline $1 \mathrm{H}-1,25$ & 0.362382 & 26.3 & - & 0.25 & 0.112528 \\
\hline $1 \mathrm{H}-1,25.5$ & 0.367379 & 27.4 & - & 0.255 & 0.112528 \\
\hline $1 \mathrm{H}-1,26$ & 0.372376 & 25.8 & - & 0.26 & 0.112528 \\
\hline $1 \mathrm{H}-1,26.5$ & 0.377373 & 26.2 & - & 0.265 & 0.112528 \\
\hline $1 \mathrm{H}-1,27$ & 0.38237 & 26.4 & - & 0.27 & 0.112528 \\
\hline $1 \mathrm{H}-1,27.5$ & 0.387367 & 26.3 & - & 0.275 & 0.112528 \\
\hline $1 \mathrm{H}-1,28$ & 0.392364 & 26.5 & - & 0.28 & 0.112528 \\
\hline $1 \mathrm{H}-1,28.5$ & 0.397361 & 27.1 & - & 0.285 & 0.112528 \\
\hline $1 \mathrm{H}-1,29$ & 0.402358 & 27.1 & - & 0.29 & 0.112528 \\
\hline $1 \mathrm{H}-1,29.5$ & 0.407355 & 26.7 & - & 0.295 & 0.112528 \\
\hline $1 \mathrm{H}-1,30$ & 0.412352 & 27.3 & - & 0.3 & 0.112528 \\
\hline $1 \mathrm{H}-1,30.5$ & 0.417349 & 28 & - & 0.305 & 0.112528 \\
\hline
\end{tabular}

Only a portion of this table appears here. The complete table is available in ASCII. 
Table T21. Constrained tie points for depth-age relationship, Site U1430.

\begin{tabular}{|c|c|c|c|c|c|c|c|}
\hline $\begin{array}{l}\text { Selected ties for } \\
\text { depth-age lines }\end{array}$ & $\begin{array}{l}\text { Event } \\
\text { type }\end{array}$ & Bioevents and epoch boundaries & $\begin{array}{c}\text { Depth } \\
\text { CCSF-A (m) }\end{array}$ & $\begin{array}{c}\text { Depth range } \\
\quad( \pm)\end{array}$ & $\begin{array}{l}\text { Age } \\
(\mathrm{Ma})\end{array}$ & $\begin{array}{l}\text { Age range } \\
( \pm)\end{array}$ & $\begin{array}{c}\text { Sedimentation } \\
\text { rate }(\mathrm{m} / \mathrm{m} . \mathrm{y} .)\end{array}$ \\
\hline \multirow[t]{7}{*}{ Top } & & & 0.00 & & 0.000 & & \\
\hline & $\mathrm{R}$ & LO Lychnocanoma sakaii & 1.98 & 1.77 & 0.050 & 0.000 & 44.4 \\
\hline & $\mathrm{CN}$ & FO Emiliania huxleyi & 8.69 & 4.95 & 0.290 & 0.000 & \\
\hline & $\mathrm{R}$ & LO Amphimelissa setosa & 8.69 & 4.95 & 0.080 & 0.000 & \\
\hline & $\mathrm{R}$ & LO Spongodiscus sp. & 18.76 & 5.13 & 0.290 & 0.000 & \\
\hline & $\mathrm{D}$ & LO Proboscia curvirostris & 20.78 & 3.11 & 0.300 & 0.000 & \\
\hline & $\mathrm{PF}$ & LO Neogloboquadrina kagaensis group & 31.34 & 6.53 & 0.700 & 0.000 & \\
\hline \multirow[t]{2}{*}{ Paleomag } & PM & Bottom of C1n (Brunhes/Matuyama) & 34.71 & 3.06 & 0.781 & 0.000 & \\
\hline & $\mathrm{PF}$ & Neogloboquadrina pachyderma (coiling change, D to S) & 42.91 & 4.99 & 1.190 & 0.050 & 11.4 \\
\hline \multirow[t]{5}{*}{ Unit $I A / I B$} & & & 46.77 & & 1.839 & & \\
\hline & $\mathrm{R}$ & LO Axoprunum acquilonium & 48.87 & 4.87 & 1.450 & 0.250 & 11.4 \\
\hline & $\mathrm{D}$ & LO Neodenticula koizumii & 54.38 & 0.64 & 2.000 & 0.000 & \\
\hline & $\mathrm{R}$ & FO Cycladophora davisiana & 58.83 & 5.09 & 2.700 & 0.000 & \\
\hline & $\mathrm{R}$ & LO Hexacontium parviakitaensis & 58.83 & 5.09 & 2.700 & 0.000 & \\
\hline \multirow[t]{3}{*}{ Unit IB/IIA } & & & 60.02 & & 3.003 & & \\
\hline & $\mathrm{D}$ & LO Neodenticula kamtschatica & 63.00 & 0.93 & 2.650 & 0.050 & 11.4 \\
\hline & $\mathrm{D}$ & FO Neodenticula koizumii & 67.04 & 0.75 & 3.665 & 0.265 & \\
\hline \multirow[t]{3}{*}{ Unit $\| A / I I B$} & & & 76.54 & & 4.453 & & \\
\hline & $\mathrm{R}$ & FO Hexacontium parviakitaensis & 78.64 & 4.81 & 4.100 & 0.200 & 11.4 \\
\hline & $\mathrm{R}$ & LO Lipmanella redondoensis & 78.64 & 4.81 & 5.060 & 0.000 & \\
\hline \multirow{3}{*}{ Biostrat } & & & 83.45 & & 5.060 & & \\
\hline & $\mathrm{R}$ & FO Axoprunum acquilonium & 78.64 & 4.81 & 7.100 & 0.000 & 0.0 \\
\hline & $\mathrm{R}$ & LO Cycladophora nakasekoi & 78.64 & 4.81 & 7.400 & 0.000 & \\
\hline \multirow[t]{4}{*}{ Biostrat } & & & 83.45 & & 7.400 & & \\
\hline & $\mathrm{R}$ & FO Larcopyle pylomaticus & 88.68 & 5.23 & 5.300 & 0.000 & 0.0 \\
\hline & $\mathrm{D}$ & FO Thalassiosira oestrupii & 88.68 & 5.23 & 5.560 & 0.000 & \\
\hline & $\mathrm{D}$ & LCO Thalassionema schraderi & 98.91 & 5.00 & 7.670 & 0.000 & \\
\hline \multirow[t]{9}{*}{ Unit IIB/IIIA } & & & 103.17 & & 7.891 & & \\
\hline & D & FCO Thalassionema schraderi & 129.42 & 4.95 & 8.500 & 0.000 & 40.2 \\
\hline & D & LO Denticulopsis katayamae & 139.32 & 4.95 & 8.700 & 0.000 & \\
\hline & $\mathrm{R}$ & LCO Lychnocanoma magnacornuta & 149.44 & 5.17 & 9.100 & 0.000 & \\
\hline & $\mathrm{R}$ & FO Cycladophora nakasekoi & 190.18 & 4.58 & 10.100 & 0.000 & \\
\hline & $\mathrm{R}$ & LO Cyrtocapsella japonica & 190.18 & 4.58 & 10.100 & 0.000 & \\
\hline & $\mathrm{D}$ & LO Denticulopsis hustedtii & 190.18 & 4.58 & 10.200 & 0.000 & \\
\hline & $\mathrm{R}$ & LO Dendrospyris uruyaensis & 210.14 & 5.27 & 10.100 & 0.000 & \\
\hline & $\mathrm{R}$ & FO Lychnocanoma magnacornuta & 247.30 & 2.94 & 11.800 & 0.000 & \\
\hline \multirow[t]{4}{*}{ Unit IIIA/IIIB } & & & 256.79 & & 11.714 & & \\
\hline & $\mathrm{R}$ & FO Dendrospyris uruyaensis & 257.21 & 3.04 & 11.800 & 0.000 & 40.2 \\
\hline & $\mathrm{R}$ & LO Eucyrtidium inflatum & 257.21 & 3.04 & 11.800 & 0.000 & \\
\hline & $\mathrm{R}$ & LO Lithopera renzae & 257.62 & 2.63 & 11.800 & 0.000 & \\
\hline \multirow[t]{3}{*}{ Biostrat } & & & 260.25 & & 11.800 & & \\
\hline & D & FCO Denticulopsis simonsenii & 257.62 & 2.63 & 13.100 & 0.000 & 3.3 \\
\hline & $\mathrm{R}$ & RD Cyrtocapsella tetrapera & 262.45 & 2.36 & 12.600 & 0.000 & \\
\hline \multirow[t]{3}{*}{ Unit IIIB/IV } & & & 264.63 & & 13.121 & & \\
\hline & $\mathrm{R}$ & LO Dendrospyris sakaii & 267.50 & 2.69 & 14.800 & 0.000 & 3.3 \\
\hline & $\mathrm{R}$ & LO Pentactinosphaera hokurikuensis & 270.04 & 2.59 & 15.000 & 0.000 & \\
\hline Biostrat & & & 270.20 & & 14.800 & & \\
\hline
\end{tabular}

$\mathrm{R}=$ radiolarian, $\mathrm{D}=$ diatom, $\mathrm{PF}=$ planktonic foraminifer, $\mathrm{CN}=$ calcareous nannofossil, $\mathrm{PM}=$ paleomagnetism. $\mathrm{LO}=$ last occurrence, $\mathrm{LCO}=$ last common occurrence, $\mathrm{FO}=$ first occurrence, $\mathrm{FCO}=$ first common occurrence, $\mathrm{RD}=$ rapid decrease. $\mathrm{D}$ to $\mathrm{S}=$ dextral to sinistral coiling change. 